LUCIANO PICOLI GAGNO

\title{
ENSAIO SOBRE A COLETIVIZAÇÃO DE DEMANDAS INDIVIDUAIS
}

\author{
DOUTORADO EM DIREITO
}

\begin{abstract}
ORIENTADOR: PROFESSOR DOUTOR MARCELO JOSÉ MAGALHÃES BONICIO
\end{abstract}

FACULDADE DE DIREITO DA UNIVERSIDADE DE SÃO PAULO SÃO PAULO - 2014 


\title{
ENSAIO SOBRE A COLETIVIZAÇÃO DE DEMANDAS INDIVIDUAIS
}

\begin{abstract}
Tese apresentada à Banca Examinadora da Faculdade de Direito da Universidade de São Paulo, como exigência parcial para obtenção do titulo de Doutor em Direito na área de concentração Direito Processual, sob a orientação do Professor Doutor Marcelo José Magalhães Bonicio.
\end{abstract}

\section{SÃO PAULO}


BANCA EXAMINADORA

PROF. DR. MARCELO JOSÉ MAGALHÃES BONICIO 
Ao ZECA, meu fruto, ser por quem nutro o maior amor do mundo e que me proporciona experiências inimagináveis, na minha busca contínua pela conquista da sua admiração. 


\section{AGRADECIMENTOS}

Agradeço a Deus e a Jesus Cristo, que mantém vivo e motivado pelas lições de amor ao próximo e humildade.

Agradeço aos meus pais José Maria e Luci, e irmãos Leonardo e Dinah, pela constante transmissão de afeto e ensinamentos, que me proporcionaram a construção de um patrimônio afetivo valioso.

Agradeço ao meu filho Zeca, por me amar e me deixar amá-lo. Agradeço a minha namorada Léia, pelo amor, carinho e dedicação devotados a mim, de maneira constante e incondicional.

Agradeço também ao meu professor orientador Marcelo José Magalhães Bonicio, pela atenção que me foi dispensada, o respeito com o qual sempre me tratou e a oportunidade que me ofereceu. Não poderia me esquecer de agradecer também aos professores José Roberto dos Santos Bedaque e Heitor Vitor Mendonça Sica, verdadeiros amigos, fundamentais nessa minha caminhada.

Agradeço ainda a todos os professores que lecionaram de maneira magnifica para mim, tendo toda a paciência e o respeito em me auxiliar no esclarecimento de duvidas e na busca pelo aprimoramento das minhas convicções, merecendo destaque os professores Cândido Rangel Dinamarco, José Rogério Cruz e Tucci, Carlos Alberto Carmona, Flávio Luiz Yarshell, Paulo Henrique dos Santos Lucon, Oreste Nestor de Souza Laspro, Antonio Carlos Marcato.

Agradeço aos amigos Daniel Penteado de Castro, Zé Eduardo, Rafael Alfredi, Fernando Cais, Fabio Tabosa, que conquistei ao longo do curso e que passei a admirar, e a compartilhar momentos importantes.

Agradeço por fim, a Faculdade de Direito de Vitória - FDV, a Faculdade Castelo Branco - FCB, aos amigos de sempreAlexandre Ferraz Fernandes, Airton Alonso e Pablo Queiroz Aguete, e aos colegas de escritório, por todo apoio ao longo dessa jornada. 


\section{RESUMO}

GAGNO, Luciano Picoli. Ensaio sobre a coletivização de demandas individuais.2014, 287 p. Tese (Doutorado em Direito) - Faculdade de Direito da Universidade de São Paulo, São Paulo, 2014.

A presente tese visou à discussão sobre a possibilidade de utilização de técnica processual, capaz de permitir a coletivização de demanda individual, mediante decisão judicial de ofício, desde que visualizada a presença de alguma hipótese de direito coletivo lato sensu, com o objetivo de se ampliar o uso desse tipo de processo. Nesse contexto, foi defendida a criação de técnica que permitisse ao juiz, após a realização de um contraditório prévio, coletivizar demanda individual que tenha por objeto direito indivisível ou individual homogêneo, cabendo a ele analisar a presença do respectivo direito com base na inicial, na manifestação da parte contrária, nos documentos dos autos e nas máximas de experiência, que lhe permitirão ainda, aferir sobre a numerosidade de pessoas envolvida naquela situação. Naturalmente, que a utilização de tal técnica gera perplexidade, razão pela qual se falou na conveniência de que tal técnica seja prevista em lei, o que está acontecendo no projeto do novo CPC, que, contudo, merece críticas por ser tímido, não abrangendo os direitos individuais homogêneos e não autorizando o juiz a agir de oficio. Outro ponto importante abordado no trabalho foi o da necessidade de se reconhecer a legitimidade individual para o processo coletivo, a fim de que a coletivização judicial não fique refém do alvedrio dos entes legitimados e, também, que o autor originário não fique excluído do procedimento. Para tanto, defendeu-se a tese de que tal legitimação, assim como a proporia técnica de coletivização, não oferece risco algum à ordem constitucional ou infraconstitucional, não podendo prejudicar direitos individuais e só afetando os direitos indivisíveis quando a sentença coletiva de improcedência se fundar nas provas dos autos, após um procedimento em que o Ministério Público necessariamente terá de participar. Por fim, falou-se nos benefícios que deverão ser trazidos pelo uso dessa técnica, sintetizados no ganho de economia e celeridade processual, pela redução do número de demandas, e segurança jurídica, por se reduzir o risco de conflitos práticos entre sentenças contrárias sobre bens indivisíveis, e por se proporcionar um acesso à justiça mais amplo.

Palavras-chaves: Coletivização judicial de demanda individual - Legitimidade individual para demandas coletivas - Ampliação do uso do processo coletivo. 


\section{RIASSUNTO}

GAGNO, Luciano Picoli. Saggiosullacollettivizzazionedelleazioniindividuali. 2014, 287 p. Tesi de Dottorato - Faculdade de Direito da Universidade de São Paulo, São Paulo, 2014.

Questatesi mira a discuterelapossibilitàdiutilizzazionedilatecnicaprocedurale, in grado

diconsentirelacollettivizzazionedelladomandaindividualecondecisionegiudiziariadiufficio, dal momento chehanno visto lapresenzadialcuneipotesididirittocoletivo lato sensu, conl'obiettivodiestenderel'utilizzazionediquesto tipo di processo. In questo contesto, èsostenutalacreazioneditecnicache ha permessoilgiudice, dopo avercondotto una primacontraddittoriocollettivizareladomandaindividualeche ha ildirittoindivisibileo individualeomogeneo, lasciandolodianalizzarelapresenzadel loro dirittosulla base iniziale, manifestazionedellacontroparte, i documentidelfascicolo e lemassimediesperienza, che vi permetteràdivalutare ulteriormentelanumerositàdellepersonecoinvolte in quellasituazione.Naturalmente, l'usodi tale tecnicageneraperplessità, cheèil motivo per cuiabbiamoparlatonellacomoditàdi una tale tecnicaè prevista dallalegge, ciòchestaaccadendonelnuovo $\mathrm{CPC}$, che, però, meritacritiche per essereprogettotimido, non copreildirittiindividualiomogenei e non consentono al giudiceagirediufficio. Unaltro tema importante affrontatonellostudioèstatalanecessitàdiriconoscerel'individuolegittimità al processo collettivo, in modo cheilgiudice non ètenuto in ostaggiodicollettivizzazioneladiscrezionalitàdellegittimidallalegge e anchechel'autoreoriginale non vieneeliminatodallaprocedura.Per entrambi, ha difesolatesiche tale legittimazione, oltre a proporrelatecnicacollettivizzazione, offrealcunrischio per l'ordinecostituzionale o infra, non potrebberodanneggiare i dirittiindividuali e dirittiindivisibili solo quando si basailgiudiziocollettivodilicenziamentoglielementidi prova dinanzialla Corte, dopo una procedura in cuiil M.P.dovrà necessariamente partecipare.Infine, abbiamoparlato dei benefici per essereportaticonl'usodiquestatecnica, sintetizzati per l'economia e sicurezzaprocedurale, numero diducendoil nieste eriducendoilrischiodiconflittipraticiatragiudizisulldirittiindivisibili, $\quad$ e $\quad$ se $\quad$ si fornisceunpiùampioaccessoallagiustizia. 
Parole chiavi:Collettivizzazionegiudiziariadelladomandaindividuale

Legittimitàindividualealleazionicollettive - Ingrandimentodel'uso del processocollettivo.

\section{RÉSUMÉ}

Gagno, Luciano Picoli. Essaisurlacollectivisationdes demandes individuelles. 2014, 287 p. Thèse de Docteur- Faculdade de Direito da Universidade de São Paulo, São Paulo, 2014.

Cettethèseavaitpourobjectifdiscuterlapossibilité d'utiliserlatechniqueprocedurel, capable de permettrelacollectivisation de la demande individuelle par décisionjudiciaire d'office, carilconsidéraitlaprésence de certaineshypothèses de droitcollectif lato sensu, danslebut d'étendrel'utilisation de cetype de processus. Danscecontexte, il a étépréconisélacréationtechniquequipermettaitaujuge, aprèsavoirprocédé unecontradictoirepréable de collectiviserdemande individuellequi a ledroitindivisible ouindividuelhomogène, lelaissant à analyserlaprésence de leurdroitsur la base initiale, manifestation de lapartie adverse, lespiècesdudossier et lesmaximes de l'expérience, cequivouspermettra

d'évaluerplusnumerositysurlespersonnesimpliquéesdanscettesituation.Naturellement,

l'utilisation d'une telletechniquegénèrelaperplexité, et c'estpourquoinousavonsparlédansleconfort d'une telletechnique est prévue par laloi, cequi se passe dansle nouveau CPC, qui, cependant, méritela critique pourêtreprojettimide, ne couvrantpasledroitsindividuelshomogènes et ne permettantpasaujuge d'agir d'office. Une autrequestion importante abordéedansl'étudeétaitlanécessité de reconnaîtrelalégitimitéindividuelleauprocessuscollectif, de sorte que le tribunal n'est pastenuenotagelacollectivisationladiscrétion deleslegitimes pourlaloi et aussi que l'auteur original ne soitpassupprimé de laprocédure.Pourlesdeux, a défendulathèse que cettelégitimation, ainsi que de proposerlatechniquelacollectivisation, proposeaucun risque pourl'ordreconstitutionnel ou infra, ne peut que nuire à desdroitsindividuels et desdroitsindivisiblesaffectantlorsquelejugementcollectif de licenciement se fondelapreuvedevantlaCour, après une procéduredanslaquellele Parquetdevranécessairementparticiper.Enfin, nousavonsparlédesavantages d'êtreapportés par l'utilisation de cettetechnique, synthétiséesdansl'économieet de gagnerunprocèsrapide, enréduisantlenombre de demandes, et de sécuritéjuridique, enréduisantle risque de conflits 
pratiques entre lesjugementscontraíres surlesbiensindivisible, et si vousfournissezunaccèspluslarge à la justice.

Mots-clés: collectivisationjudiciaire de lademande individuelle - légitimitéindividuelleaux demandes collectives - étendrel'utilisation de laprocédurecollective.

\section{SIGLAS E ABREVIATURAS}

ACP - Ação Civil Pública

ADI - Ação Direta de Inconstitucionalidade

AgRg - Agravo Regimental

AI - Agravo de Instrumento

AP - Ação Popular

AREsp - Agravo em Recurso Especial

CC - Conflito de Competência

CDC - Código de Defesa do Consumidor

$\mathrm{CF}$ - Constituição Federal

CNJ - Conselho Nacional de Justiça

CPC - Código de Processo Civil

CRFB - Constituição da República Federativa do Brasil

DJ - Diário da Justiça

DJe - Diário da Justiça eletrônico

EREsp - Embargos de Divergência em Recurso Especial

Min. - Ministro

M.P. - Ministério Público

PL - Projeto de Lei

RE - Recurso Extraordinário

Rel. - Relator

REsp - Recurso Especial

STF - Supremo Tribunal Federal

STJ - Superior Tribunal de Justiça 


\section{SUMÁRIO}

INTRODUÇÃO E PROPOSTA..................................................................17

\section{PARTE I - A TÉCNICA DE COLETIVIZAÇÃO JUDICIAL DE DEMANDAS INDIVIDUAIS}

1 A MASSIFICAÇÃO DOS LITIGIOS E AS DEMANDAS

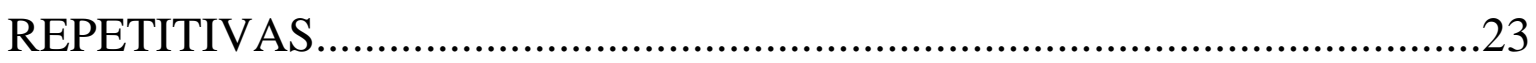

2 EFETIVIDADE E PROCESSO COLETIVO_.............................................29

3 A TECNICA DE COLETIVIZAÇÃO DE DEMANDAS INDIVIDUAIS.34

4 A DECISÃO QUE PODERIA TRANSFORMAR UM PROCESSO INDIVIDUAL EM COLETIVO......................................................................40

4.1 Os pontos que necessariamente serão abordados nessa decisão.....40

4.2 A análise da representatividade adequada......................................45

4.3 A identificação de um direito como individual homogêneo ou indivisível, da utilidade da tutela coletiva e a importância das máximas

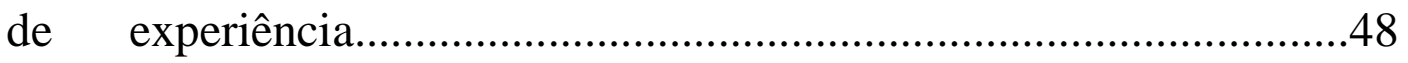


4.4 A imprescindibilidade do contraditório prévio e o momento limite para a coletivização.

4.5 A (des)necessidade de emenda à inicial

4.6 A competência para a conversão e o julgamento da demanda individual coletivizada.

4.7Das hipóteses em que não deverá haver coletivização. .64

4.8Dos casos em que há cumulação de pedidos individuais heterogêneos .66

4.9 $\mathrm{O}$ direito individual de ação frente à técnica de coletivização de demanda individual .70

4.10 A possibilidade limitada de coletivização de demandas contra a coletividade (ação coletiva passiva). .75

4.11 A coletivização e sua repercussão sobre os processos individuais.

4.12A fase instrutória e a sentença que julga a demanda coletivizada.78 4.13 A necessidade de norma que regulamente os requisitos e as consequências da coletivização .80

4.14 O projeto de lei existente 81

4.15 A proximidade entre a técnica de coletivização e as técnicas britânicas para litígios com múltiplas partes(processo por representação e litígios em grupo - GLO). .83

5 A RELEVÂNCIA DO SISTEMA NORTE AMERICANO DE CLASS ACTIONS PARA A IDEIA DE COLETIVIZAÇÃO DE DEMANDAS INDIVIDUAIS. 
5.1 Os requisitos de admissibilidade das classactions(prerequisites).89

5.2 As hipóteses genéricas em que se admitem as classactions (typesof class actions)

5.3 A decisão que certifica a ação como uma classaction (certification order).

6 A EXISTÊNCIA DE TÉCNICAS SIMILARES NO SISTEMA 100

6.1 A técnica de extensão da sentença normativa na justiça do trabalho. 100

6.2 A súmula vinculante e a sistemática da repercussão geral e dos recursos repetitivos 102

6.3 A proposta contida no projeto do novo cpc: incidente de resolução de demandas repetitivas. 109

6.4 A extensão dos efeitos de decisões relativas a direitos sociais constitucionais, proposta por CARLOS ALBERTO SALLES.

\section{A UTILIDADE DA COLETIVIZAÇÃO NA BUSCA POR CELERIDADE} E EFETIVIDADE

7.1 A utilidade nos casos de direitos individuais homogêneos canalizados por milhões de ações repetitivas 116

7.2 A utilidade nos casos de direitos indivisíveis. 120

8 UMA PERSPECTIVA CONSTITUCIONAL SOBRE O ASSUNTO.......125

9 UMA PERSPECTIVA INFRACONSTITUCIONAL SOBRE O ASSUNTO. 
10 A INSTRUMENTALIDADE DO PROCESSO E A TÉCNICA DE COLETIVIZAÇÃO DE DEMANDAS: aspecto positivo e negativo.

\section{PARTE II - A LEGITIMIDADE INDIVIDUAL PARA PROSSEGUIR NO PROCESSO COLETIVIZADO}

11 UMA ANÁLISE DA AUSÊNCIA DE PREVISÃO LEGAL EXPRESSA SOBRE A LEGITIMIDADE INDIVIDUAL PARA DEMANDAS COLETIVAS E SUA INFLUÊNCIA SOBRE O TEMA..............................143

11.1 Os mecanismos de inibição do abuso processual..........................144

$11.2 \mathrm{O}$ risco de má representação pelo indivíduo e sua mitigação pela participação obrigatória do Ministério Público.

11.3 O risco de má representação pelo indivíduo e sua mitigação pelos poderes instrutórios do juiz.

$11.4 \mathrm{O}$ risco de má representação pelo indivíduo e sua mitigação pelo regime da coisa julgada coletiva 155

11.5 A ação penal privada subsidiária da pública e sua relação com a legitimidade individual para demandas coletivas. 162

11.6 A legitimidade individual para a ação popular e sua extensão para os demais campos da tutela coletiva. 166 11.7 A legitimidade individual para hipóteses de direitos indivisíveis ações pseudoindividuais - e sua influência sobre a legitimação do indivíduo para demandas coletivas. 172

11.8 A instrumentalidade do processo e sua influência sobre a legitimidade individual para demandas coletivas. 175

11.9 A teoria da instrumentalidade das formas e sua influência sobre a legitimidade individual para demandas coletivas. 178 
11.10 Legitimidade extraordinária do indivíduo: democracia ou abuso?.

11.11 As vantagens obtidas com a legitimidade individual para demandascoletivas.

11.12 A restrição criada pelo rol de legitimados da Lei de ACP e do CDC. 191

PARTE III - ANÁLISE PROSPECTIVA DOS RESULTADOS IDEALIZADOS COM A COLETIVIZAÇÃO SOBRE DIREITOS INDIVISIVEIS OU INDIVIDUAIS HOMOGÊNEOS

\section{A COLETIVIZAÇÃO DE DEMANDAS VERSANDO SOBRE} DIREITOS INDIVISÍVEIS 198

12.1 Os casos de ações pseudoindividuais: a ausência de taxatividade e a decisão que converte uma ação pseudoindividual em coletiva 198

12.2 A sistemática da coisa julgada em relação às ações pseudoindividuais. .202

12.3 As vantagens decorrentes da coletivização de demanda individual que verse sobre direitos indivisíveis: a coisa julgada secundumeventum probationise a extensão objetiva da coisa julgada (aproveitamentoin utilibus). .202

13 A COLETIVIZAÇÃO DE DEMANDAS VERSANDO SOBRE

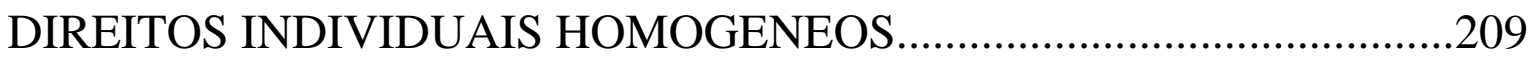

13.1Uma visão ampliada dos direitos individuais homogêneos e a decisão que converte uma ação individual em coletiva..................................209

13.1.1 O significado do termo homogêneo...............................209 
13.1.2 A maior eficiência mesmo nas hipóteses de direitos sem a predominância de questões comuns. 212

13.1.3A técnica de ampliação objetiva da demanda coletiva e sua relaçãocom uma compreensão mais abrangente do termo

homogêneo. 217

13.1.4 A decisão que coletiviza ação individual versando sobre direitos individuais homogêneos. .221

13.2 A molecularização das lides individuais e o problema das liquidações e execuções atomizadas. .225

13.2.1 A possibilidade de uso da tutela mandamental como meio de potencialização da efetividade da tutela coletiva de direitos individuais. .229

13.2.2 O seu uso nos casos envolvendo obrigações de fazer e não fazer...... .234

13.2.3 O seu uso nos casos envolvendo obrigação de pagar quantia. 240

13.2.4 O contraditório na fixação da multa e a possibilidade de exclusão ou modificação do seu valor. 245

14 A REMESSA NECESSÁRIA COMO UMA GARANTIA EXTENSÍVEL A TODO PROCESSO COLETIVO EM QUE SE TENHA RESULTADO DESFAVORÁVEL À COLETIVIDADE. .250

\section{A IMPORTÂNCIA DOS MECANISMOS DE INFORMAÇÃO NO

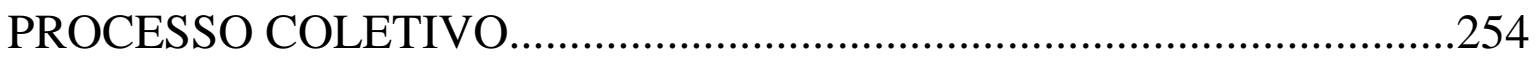


15.1 Os mecanismos de informação aos litigantes em geral e a necessidade de se possibilitar o litisconsórcio .255

15.2 Os mecanismos de informação aos litigantes que tenham ajuizado demandas individuais, a importância da cooperação do réu e a proteção das pessoas que não fruíram da devida informação .258

15.3 A ideia do cadastro nacional de processos coletivos e a alegação de conexão, continência, litispendência e coisa julgada 261

\section{ANEXOS}

ANEXO I: PL N. 8.046/2010

ANEXO II: PROPOSTA DE TÉCNICA DE COLETIVIZAÇÃO JUDICIAL DE DEMANDAS INDIVIDUAIS COMO RESULTADO DESTA TESE..292 


\section{INTRODUÇÃO E PROPOSTA}

O presente trabalho tem como ponto de partida e força motriz, o sentimento de irresignação com a total ineficiência da atividade jurisdicional para a consecução dos fins que lhe são corolários, de pacificação dos conflitos por meio da aplicação das normas vigentes, o que pode ser percebido por todo operador do direito e, naturalmente, por qualquer cidadão que tenha alguma demanda pendente em juízo.

Tal problemática, de demora processual, muitas vezes atribuída à falta de estrutura do Poder Judiciário, não pode ser reduzida a esse fator, que apesar de profundamente relevante, não depende apenas de estudos e teorias para ser resolvido, dependendo sim, de investimentos que fogem do campo e do domínio acadêmico para acontecer.

Nesse contexto, através de uma análise da realidade dos litígios e dos foros que os abrigam atualmente, com o objetivo de identificar fatores outros que possam ser objeto de estudo acadêmico, voltado, especialmente, ao aprimoramento da técnica processual e não da estrutura judiciária, pudemos perceber, conforme se extrai especialmente do capítulo 1, que a demora atual se deve, também, ao exagerado volume de demandas que chegam ao Poder Judiciário, emergindo daí, uma inquietude voltada à compreensão desse fenômeno e posterior possibilidade de se propor alguma mudança.

Dessa maneira, conforme nos aprofundamos em nossa inquietação, alguns dados e estudos nos ofereceram subsídios,para identificarmos que grande parte dos litígios pendentes envolvem litigantes habituais, em relações indivisíveis ou homogêneas, que são construídas por eles com os indivíduos em geral, sejam eles servidores públicos, candidatos a um concurso público, consumidores, acionistas ou simples vítimas de eventos danosos.

Ademais, pudemos constatar, que desde há muito tempo a doutrina nacional e estrangeira propõe o uso do processo coletivo como um dos meios de se amenizar o problema de excesso de processos, causados pela massificação das relações jurídicas envolvendo direitos indivisíveis ou homogêneos.

Isso, sem falar na notória tendência legislativa, de criar mecanismos de objetivação da atividade jurisdicional, tais como a súmula vinculante, a repercussão geral e os recursos repetitivos, que só fazem confirmar a crise vivida atualmente com a lentidão dos processos, 
decorrente do número excessivo de trabalho, a ser desempenhado por um Judiciário que ainda se apresenta pouco estruturado para tanto.

Contudo, ao mesmo tempo em que se constatou essa realidade de massificação dos litígios, de defesa doutrinária do uso do processo coletivo e de tendência legislativa de objetivação da atividade jurisdicional, se pode constatar também, uma baixíssima repercussão de processos coletivos no foro em geral e na vida das pessoas que dependem do Judiciário para terem seus direito protegidos, motivo pelo qual, norteamos a nossa pesquisa sobre o seguinte problema: como poderíamos potencializar o uso do processo coletivo, manuseando-o na exata medida e proporção exigida pelo atual contexto social e jurídico?

Nessa conjuntura, a hipótese visualizada por nós, foi a de possibilitar a ampliação do uso da tutela coletiva, por meio de uma técnica que possibilitasse ao juiz, de oficio, diante de um caso individual, mas que envolvesse direitos indivisíveis ou individuais homogêneos, coletivizar a respectiva demanda, para que a atuação jurisdicional que dali resultasse tivesse os efeitos e a abrangência de um processo coletivo.

A partir desse cenário, propusemos, especialmente no capítulo 4, a construção de uma técnica que permitisse a consecução do fim ora colimado, ou seja, uma técnica que permitisse ao juiz, por meio de uma decisão judicial, transformar um caso individual em coletivo, desde que fossem respeitados certos direitos e deveres, como o de fundamentação e o contraditório, e alguns limites também, como os impostos pelas regras de competência e pelo direito fundamental à razoável duração do processo.

Caminhando por essa senda, realizamos no capítulo 5, um breve estudo do direito norte-americano sobre as classactions, sem dúvida o exemplo mais bem sucedido de uso do processo coletivo para a consecução dos fins jurisdicionais, visando com isto, à construção da melhor técnica, que permitisse a identificação dos pressupostos adequados para a coletivização, das hipóteses em que ela ocorreria e de como a decisão funcionaria, tudo baseado no regime de certificação, previsto na rule 23 , que é a principal fonte normativa do processo coletivo norte-americano.

No capítulo 6, realizamos um estudo de algumas técnicas existentes em nosso direito positivo, que demonstram, senão uma tendência, ao menos a necessidade de se ter uma atuação jurisdicional mais objetiva, que prescinda de realizar infinitas vezes os julgamentos de questões similares, pelo desperdício de tempo e recursos envolvidoscom tal 
repetição, o que corrobora os fundamentos pela defesa de uma ampliação do processo coletivo, capaz de proporcionar uma atuação molecularizada sobre os litígios de massa.

Face ao panorama que foi se desvelando, ao elaborar o capítulo 7, onde falamos da importância do processo coletivo para a celeridade e efetividade da atividade jurisdicional, podemos constatar que não só a economia é proporcionada com o uso do processo coletivo, mas também a segurança jurídica, seja pelos inúmeros problemas que permeiam nosso ordenamento, em se tratando de coisa julgada envolvendo direito indivisível objeto de processo individual, seja pelo problema ligado a falta de isonomia, quando decisões díspares são prolatadas sobre direitos individuais homogêneos, seja pelo problema do próprio acesso à justiça, que muitas vezes não é realizado em sua plenitude, seja pela insignificante quantia envolvida, seja pela impossibilidade de grande parte da população conhecer todos os seus direito e ter condições de manter um litigio pendente.

Para finalizar a primeira parte do trabalho, voltada exclusivamente ao estudo da coletivização de demanda individual, fizemos nos capítulos 8, 9 e 10, um estudo da técnica proposta, no cenário jurídico constitucional, infraconstitucional e instrumentalista, para avaliarmos como se daria a sua recepção e utilização no sistema atual, em vista dos princípios, das regras e dos objetivos definidos pelo atual paradigma processual.

Na segunda parte do trabalho, nos dedicamos eminentemente a analisar a possibilidade do individuo ser legitimado para o processo coletivo no ordenamento atual, partindo da premissa de que a técnica de coletivização pressupõe a legitimidade individual para demandas coletivas, para que não reste prejudicada em seu potencial de ampliação do uso da tutela coletiva.

Seria menos útil e proveitoso, defender a possibilidade de se coletivizar uma demanda, se o Judiciário dependesse da atuação de um ente legitimado como autor para prosseguir no processo,pois tal dependência reduziria o potencial ampliativo de tal técnica, que ao visar proporcionar maior utilização do processo coletivo na resolução dos conflitos modernos, poderia ficar prejudicada caso o ente legitimado não encampasse a decisão judicial, de emprestar eficácia erga omnes ou ultra partes à decisão, para afetar a todo o grupo envolvido.

Na terceira e última parte do trabalho, são vistos com maior profundidade, os resultados esperados com a utilização da técnica de coletivização judicial de demandas 
individuais, enfocando-se os efeitos que tal atuação teria no campo dos direitos indivisíveis e dos direitos individuais homogêneos.

Dessa maneira, iniciamos o capítulo 12 falando dos benefícios ligados à redução do número de processos, à definição da coisa julgada secundumeventumprobationiscomo regime apropriado à eliminação dos problemas de conflitos práticos entre sentenças que disponham sobre direito indivisíveis, e a possibilidade de extensão in utilibusdos efeitos dessa sentença, para beneficiar as pretensões individuais correspondentes.

Já no capítulo 13, fazemos inicialmente uma digressão sobre a correta compreensão do termo homogêneo, defendendo uma ampliação do seu significado, que repercuta na ampliação do uso do processo coletivo nesses casos, para depois enfrentarmos outros problemas colocados pela doutrina, como, por exemplo: o da fragmentação causada pela necessidade de liquidação e execução individual das sentenças coletivas envolvendo direitos individuais homogêneos, situação que poderia enfraquecer toda a defesa que realizamos ao modelo coletivo de resolução de conflitos.

No capítulo 14 abordamos a questão da remessa necessária envolvendo processos coletivos, o que deve ser enxergado como mais uma garantia que oferece segurança a esse modelo processual molecularizado e, portanto, combate o argumento de risco de prejuízo com a ampliação do seu uso.

Ao final, examinamos principalmente a repercussão que o processo coletivo tem sobre os indivíduos do grupo, tenham eles processos pendentes ou não, bem como sobre demandas individuais ou coletivas total ou parcialmente idênticas, para entendermos de que forma isso poderia pesar em favor ou em desfavor da nossa proposta.

Após a apresentação das nossas conclusões, gerais e específicas, apresentamos dois anexos onde trazemos para o conhecimento e debate,parte do projeto de lei $n^{\circ} 8.046$, sobre o novo Código de Processo Civil, já aprovado na Câmara dos Deputados e a espera de aprovação no Senado Federal, especificamente no que concerne ao procedimento de coletivização de demanda individual que fora previsto, fazendo, no anexo seguinte, uma proposta de modificação de alguns pontos, que por terem sido objetos desta pesquisa, puderam ser bem refletidos e calcados em conclusões fundamentadas, que nos orientam a seguir caminhos diversos dos adotados no referido projeto de lei.

Todo nosso estudo foi embasado no método dedutivo, por meio do qual partimos de regras gerais concernentes ao processo, especialmente ao processo coletivo, para 
chegarmos a conclusões específicas, voltadas à problemática colocada na parte inicial, de se possibilitar a coletivização de demanda individual como meio de se ampliar o uso do processo coletivo.

Para a realização da pesquisa ora apresentada realizamos fundamentalmente pesquisa bibliográfica e jurisprudencial, fundadas em obras jurídicas nacionais e estrangeiras, e em decisões judiciais oriundas das mais altas cortes nacionais. 
PARTE I - A TÉCNICA DE COLETIVIZAÇÃO JUDICIAL DE DEMANDAS INDIVIDUAIS 


\section{A MASSIFICAÇÃO DOS LITIGIOS E AS DEMANDAS REPETITIVAS}

Não é de hoje que se aborda o fato das sociedades modernas terem sofrido profundas transformações nos últimos séculos ${ }^{1}$, que modificaram não apenas a forma como elas se estruturam e podem ser enxergadas, como também os valores que constituem o seu arcabouço axiológico e orientam a conduta das pessoas que as compõem.

As mudanças estruturais anunciaram os rumos atuais desde o princípio da Era Moderna, com a unificação dos Estados Nações, o desenvolvimento de novas parcerias e empreendimento comerciais, a intensificação do comércio nas grandes cidades e entre elas, a maior concentração de pessoas nos centros urbanos (conhecidos hoje como megalópoles ${ }^{2}$ ), sendo todos estes eventos relacionados entre si.

Eles permitiram a construção de um modelo civilizatório próximo do atual, ou seja, com grandes aglomerações de pessoas em centros urbanos e a tessitura de relações jurídicas massificadas nesses locais, principalmente como consequência do desenvolvimento comercial.

Seguindo essa tendência, a revolução industrial recrudesceu as consequências acima apontadas, pois a partir do desenvolvimento de indústrias nessas grandes cidades, a concentração populacional aumentou e passou a padecer de novos problemas, decorrentes das novas relações jurídicas de massa que eclodem nesses meios ${ }^{3}$.

Grandes modelos societários se expandem, o nível de consumo aumenta significativamente e não apenas em quantidade, mas em diversidade de consumidores; aos poucos, mais produtos são consumidos e cada vez mais por um número maior de pessoas.

As crises econômicas e sociais inerentes a esse novo cenário desencadeiam a conscientização sobre novos direitos, que se diferem daqueles tradicionais, criados

\footnotetext{
${ }^{1}$ Mauro CAPPELLETTI. La protecion de interesses colectivos y de grupo enel processo civil. Revista de laFacultad de Derecho,p. 74.

2 Ibid., p. 75.

${ }^{3}$ Ibid., p. 75. No mesmo sentido: Aluisio Gonçalves de Castro MENDES. In: Ações coletivas no direito comparado e nacional,p. 27, que acresce: "O direito processual, assim, deve estar preparado para enfrentar uma realidade, em que o contingente populacional mundial ultrapassa o patamar de seis bilhões de pessoas, no qual a revolução industrial se transforma em tecnológica, diminuindo as distâncias no espaço e no tempo, propiciando a massificação e globalização das relações humanas e comerciais".
} 
exclusivamente para o disciplinamento de relações comerciais, possessórias, de propriedade, família ou sucessões; os direitos sociais (trabalhistas, previdenciários, de educação, saúde, de consumo e ambientais) florescem, bem como a noção de interesses difusos e coletivos, exigindo do Estado um novo comportamento ${ }^{4}$.

À concepção de novos direitos, inerentes ao Estado Social, se soma uma nova forma de se compreendê-los e atuá-los, típica do Estado Democrático de Direito, que concede ao Judiciário maior espectro de atuação para a proteção de grupos e direitos humanos e sociais ${ }^{5}$, bem como amplia os canais de acesso à justiça para proteção de direitos coletivos e a resolução de pequenas causas ${ }^{6}$.

Com a escalada da confiança gozada pelo Judiciário, o que era consequência não só da necessidade de tanto, pois o executivo se mostrou frouxo na realização das politicas necessárias ${ }^{7}$, mas também da perda de créditos pelo Legislativo após a $2^{\text {a }}$ Guerra $^{8}$, passouse a aceitar de maneira mais pacífica a atuação jurisdicional numa dimensão coletivizada, concretizando normas que, ainda que abertas, exigiam respeito pela essencialidade dos valores ali encerrados.

Nada obstante a toda essa evolução, ainda hoje obstáculos são encarados à satisfação plena dos direitos, ligados principalmente ao número excessivo de processos e a ranços do passado, tradutores de um comodismo e conservadorismo, que impedem a realização de uma radical mudança no papel do Judiciário e do seu mecanismo de atuação, o Processo.

Atualmente, diante da massificação das relações sociais, massificaram-se também os conflitos decorrentes dessas relações, recheados de similitudes que permitem um tratamento homogêneo, já que possuem homogeneidade na sua formação e nas suas características ${ }^{9}$.

\footnotetext{
${ }^{4}$ Mauro CAPPELLETTI. Juízes legisladores?p. 35 e 39.

${ }^{5}$ Luis Roberto BARROSO. Fundamentos teóricos e filosóficos do novo direito constitucional brasileiro. In: p. 34-36. (Org.). A nova interpretação constitucional: ponderação, direitos fundamentais e relações privadas,

${ }^{6}$ Candido Rangel DINAMARCO. A instrumentalidade do processo,p. 391-401.

${ }^{7}$ CAPPELLETTI, op. cit. p. 41-42, nota 4.

${ }^{8}$ BARROSO, op cit. p. 26, nota 5.

${ }^{9}$ MENDES, op. cit. p. 32, nota 3.
} 
A má fabricação de um produto, por exemplo, não afeta mais a um pequeno grupo de pessoas que teria condições para consumi-lo, como no início do século XX, mas sim a milhares, às vezes milhões de pessoas.

Da mesma forma, a inclusão de cláusulas injustas em relações contratuais afeta a milhões de pessoas que celebraram o mesmo contrato para aquisição de um mesmo produto ou serviço, o não cumprimento de direitos pode afetar centenas ou milhares de empregados ou servidores, o ilícito ambiental pode causar dano a toda uma comunidade estabelecida em um bairro, uma cidade ou uma região.

No campo consumerista, milhões são as pessoas que formulam o mesmo contrato de adesão para adquirir um serviço de crédito, de telefonia, de plano de saúde entre outros serviços hoje considerados essenciais para que se tenha o mínimo de conforto.

Em relatório produzido pelo CNJ no ano de 2011, ficou constatado quesó o setor público federal e os bancos são responsáveis, em percentuais iguais, por $76 \%$ (setenta e seis por cento) do total de processos dos 100 maiores litigantes nacionais, sendo o setor bancário responsável por mais da metade de todos os processos dos 100 maiores litigantes nacionais que tramitam na justiça estadual ${ }^{10}$.

Somados, os bancos, o setor público em todas suas esferas (federal, estadual e municipal) e as empresas de telefonia são responsáveis por 95\% (noventa e cinco por cento) do total de processos dos 100 maiores litigantes nacionais, sendo 51\% (cinquenta e um por cento) para o setor público (federal 38\%, estadual $8 \%$ e municipal 5\%), 38\% (trinta e oito por cento) para o setor bancário e $6 \%$ (seis por cento) para as companhias de telefonia ${ }^{11}$, sendo certo que tais percentuais se traduzem em milhões de demandas repetitivas, que versam muitas vezes sobre direitos individuais homogêneos, relativos à validade de cláusulas contratuais e a práticas comerciais danosas para o consumidor, ou ainda sobre direitos indivisíveis, relativos a questões envolvendo servidores e concurso público.

No caso específico das justiças estaduais, com certeza o mais crítico, onde as causas versando sobre direito do consumidor são objetos de julgamento, nota-se que quase $54 \%$ (cinquenta e quatro por cento) do total de processos dos 100 maiores litigantes

10 CONSELHO NACIONAL DE JUSTIÇA. Relatório 100 maiores litigantes. Disponível em: http://www.cnj.jus.br/images/pesquisas-judiciarias/pesquisa_100_maiores_litigantes.pdf, p. 14.

${ }^{11}$ Ibid., p. 15. 
nacionais pertencem aos bancos, ficando $31 \%$ (trinta e um por cento) para o setor público e quase $10 \%$ (dez por cento) para as empresas de telefonia ${ }^{12}$.

Para se ter uma dimensão do que representam os percentuais mencionados, deve-se registrar que o número total de processos em tramite no Brasil em 2009 era de 86,6 milhões de processos, com uma taxa de congestionamento de $71 \%$ (setenta e um por cento), já que existiam pouco mais de 16.000 mil juiz e 300.000 servidores para administrar e julgar todas essas demandas ${ }^{13}$.

Esse quadro comprova não só o excessivo número de trabalho a ser realizado, em parte causada pelas demandas repetitivas envolvendo os bancos, o setor público e as empresas de telefonia, como também a total impotência da estrutura atual para resolver o problema, por carecer de servidores e juízes em numero suficiente para atuar em tantos processos.

Com o referido quadro dificilmente se conseguirá oferecer ao cidadão uma justiça realmente célere e segura, capaz de responder em um tempo razoável, por exemplo, a mais de25 milhões de demandas ajuizadas em $2009^{14}$, já que as estruturas atuais se aproximam mais da realidade de 1950, quando menos de 1 milhão de demandas eram ajuizadas anualmente no Brasil ${ }^{15}$.

Nesse cenário, o processo coletivo ganha tanta ou mais importância que o modelo individual, por ser completamente contraproducente a difusão de inúmeros processos individuais, para se resolver situações indivisíveis ou homogêneas, decorrentes de um mesmo fato ou pertinentes a um mesmo direito.

Indiscutivelmente, é muito mais útil um processo que declarará a iniquidade de uma cláusula contratual para milhões de consumidores, do que milhões de processos em que se chegue a decisões intempestivas e contraditórias, incapazes de proporcionar tutela com efetividade às pessoas protegidas pelo direito.

\footnotetext{
12 Ibid., p. 23.

13 Disponível em: http://www.cnj.jus.br/noticias/9783-pais-tem-quase-90-milhoes-de-processos-emtramitacao-na-justica.

${ }^{14}$ Ver nota 13 (relatório do CNJ sobre o número atual de processos).

${ }^{15}$ Disponívelem:http://siteresources.worldbank.org/BRAZILINPOREXTN/Resources/3817166118589564530 4/4044168-1186404259243/29Justica.pdf, apud:Natalia Martins PIMENTA. Coletivização das demanda individuais: as técnicas processuais de julgamento das demandas individuais à luz do princípio do contraditório,dissertação apresentada ao Programa de Pós-Graduação Stricto Sensu em Direito Processual Civil da Universidade Federal do Espírito Santo, como requisito parcial para obtenção do titulo de mestre em Direito Processual Civil, sob a orientação do Prof. Dr. Marcelo Abelha Rodrigues, p. 46-47.
} 
O modelo de processo individual, tradicional da cultura romano germânica, em que se tutela Tício em face de Cayo, entregando-lhe a posse do bem esbulhado, ou condenando o último ao adimplemento de determinada prestação, encontra-se completamente em crise $^{16}$.

Hoje são visualizadas inúmeras situações repetitivas, onde questões jurídicas ou fáticas similares em milhares de demandas merecerão a atuação da função jurisdicional, sendo inconcebível que essa atuação permaneça nos moldes antigos, de atomização das demandas mesmo diante de tantas transformações sociais, seja pela falta de economia e eficácia que esse modelo representa, seja pelo tratamento diferente de situações iguais que ele proporciona.

O modelo social de hoje exige um novo modelo de jurisdição e processo, sem que sejam alterados seus conceitos tradicionais; a jurisdição continua sendo a atividade estatal de pacificação dos conflitos com a aplicação dos direitos ${ }^{17}$ e o processo continua sendo o método utilizado para se alcançar esse objetivo ${ }^{18}$; sem embargo, o método de hoje não pode ser o mesmo método concebido há séculos atrás, quando Tício e Cayo ainda eram os grandes protagonistas das demandas judiciais.

Na conjuntura apresentada, mostra-se nítida a necessidade de mecanismos que ampliem a utilização do processo coletivo, pois parte-se da premissa de que tal ampliação será seguramente contributiva a um aprimoramento da tão desejada efetividade processual, mostrando-se convergente com esse discurso a presente temática, de coletivização judicial de demandas individuais e a consequente legitimidade individual para demandas coletivas.

\footnotetext{
${ }^{16}$ Ovídio A. BAPTISTA DA SILVA. Democracia moderna e processo civil. In:Candido Rangel DINAMARCO; Ada Pellegrini GRINOVER;Kazuo WATANABE(Coord.). Participação e Processo,p. 99100. O autor identifica uma crise causada pelas vertiginosas mudanças que permeiam a sociedade moderna, sem que as antigas estruturas acompanhem tais transformações: "No fundo, não seria o direito processual, como técnica de tratamento de conflitos sociais, que estaria submerso em crise irremediável, e sim a forma tradicional de processo civil, ainda muito ligada e dependente de conceitos e princípios herdados do Direito Romano".

${ }^{17}$ Antonio Carlos de Araújo CINTRA; Ada Pellegrini GRINOVER; Candido Rangel DINAMARCO. Teoria Geral do Processo,p. 129. Numa fusão dos conceitos de Carnelutti e Chiovenda, os autores das Arcadas entendem a jurisdição como "uma das funções do Estado, mediante a qual este se substitui aos titulares dos interesses em conflito para, imparcialmente, buscar a pacificação do conflito que os envolve, com justiça".

${ }^{18}$ José Roberto dos Santos BEDAQUE. Efetividade do processo e técnica processual,p. 73-74. O autor define o Processo como "método estatal de solução das crises verificadas no plano do direito material", aludindo indiretamente ao conceito de jurisdição acima transcrito.
} 
Os problemas e questionamentos advindos de tais propostas, sejam de ordem axiológica, sejam de ordem prática, serão debatidos nos tópicos seguintes, no afã de se alcançar a conclusão mais madura possível sobre o problema. 


\section{EFETIVIDADE E PROCESSO COLETIVO}

A efetividade nada mais é que a capacidade de algo realizar àquilo a que se propôs $^{19}$, e o processo, como um método de resolução de conflitos com base no direito ${ }^{20}$, para ser efetivo deverá entregar ao detentor de um direito, tudo aquilo e exatamente aquilo a que este faz jus ${ }^{21}$.

Não obstante, para se alcançar um processo efetivo se faz imperioso que se respeitem pelo menos três aspectosigualmente importantes daalmejada efetividade processual, aspectos estes que estão intimamente ligados à temática abordada nesta tese, quais sejam: a) o processo deve ser célere; b) capaz de reconstituir os fatos da maneira mais próxima possível à realidade (seguro) e; c)deve alcançar o maior número de pessoas possível $^{22}$.

Não à toa, a teoria da instrumentalidade das formas havia notado dois valores centrais, em torno dos quais gravitam as normas processuais, sendo eles: celeridade e segurança $^{23}$, mas é árdua a missão de conciliá-los na prática, pois medidas tendentes a conferir mais celeridade soem proporcionar menos segurança e o contrário também ${ }^{24}$.

\footnotetext{
${ }^{19}$ Joasé Carlos BARBOSA MOREIRA. "Notas sobre o problema da 'efetividade' do processo". Revista da AJURIS,p. 77. Ver também: José Carlos BARBOSA MOREIRA. "A efetividade do processo de conhecimento." Revista de Processo, p. 128. Neste segundo artigo o autor vai além, identificando o significado de efetividade com o de eficiência, afirmando que: "Efetivo e sinônimo de eficiente. Penso que a efetividade, aqui, consiste na aptidão para desempenhar, do melhor modo possível, a função própria do processo."

${ }^{20}$ Ibid., p. 128 (A efetividade do processo ...).

${ }^{21}$ Giuseppe CHIOVENDA. "Dell' azione nascente dal contrato preliminare". Saggididiritto processual civile, Roma, 1930, 1/110, apudBARBOSA MOREIRA, op. cit. p. 79, nota 19 (Notas sobre o problema ...). "Il processo deve dare per quanto èpossibile praticamente a chi há um dirittotuttoquelloch'egli há dirittodiconseguire."

${ }^{22}$ BARBOSA MOREIRA, op. cit. p. 128-129, nota 19 (A efetividade do processo ...). Nesse sentido, o autor ensina que: "Ouso, portanto, ajuntar à problemática da duração essas duas outras. Uma, de índole objetiva: como tornar melhor a qualidade da prestação jurisdicional cognitiva? E outra, de natureza subjetiva: como assegurar o funcionamento da máquina em beneficio do maior número possível de pessoas, repito, sem discriminações de tratamento?”. Ver também: BARBOSA MOREIRA, op. cit. p. 77-78, nota 19 (Notas sobre o problema ...). Neste segundo artigo, o autor inaugura as suas reflexões estabelecendo alguns pontos relativos à problemática essencial da efetividade, como por exemplo: a qualidade da decisão e a possibilidade de melhor aproveitamento da atividade jurisdicional. Tempos depois, tais estudos repercutiram nas ideias construídas no artigo "A efetividade do processo ...."

${ }^{23}$ José Roberto dos Santos BEDAQUE. Efetividade do processo e técnica processual,p. 49. Segundo o autor: "Processo efetivo é aquele que, observado o equilíbrio entre os valores segurança e celeridade, proporciona às partes o resultado desejado pelo direito material."

${ }^{24}$ Jose Rogério Cruz e TUCCI. "Garantia da prestação jurisdicional sem dilações indevidas como corolário do devido processo legal." Revista de Processo, p. 73.
} 
O nosso trabalho reconhece a importância de todos esses aspectos, tendo o foco voltado à obtenção de maior celeridade e abrangência da tutela jurisdicional, sem que isto represente perda de segurança ou um conflito de valores.

Aliás, nosso trabalho pressupõe que, alcançar o maior número de pessoas possível proporcionará maior celeridade e não o inverso ${ }^{25}$, como poderia parecer, quando se pensa que a prodigalização do acesso à justiça seria uma das responsáveis pela demora processual.

Quem pensa que o processo coletivo poderia impingir mais demora à atividade jurisdicional,ignora uma vertente dessa situação, qual seja: levar justiça ao máximo de pessoas possível pode gerar o efeito inverso, tornando milhares de demandas individuais desnecessárias, ou seja, proporcionando justiça mediante uma técnica que prescinda do uso de milhares de pequenas demandas individuais, corresponsáveis pelo entupimento do Poder Judiciário.

Qual a utilidade e a necessidade de se terem milhões de processos ajuizados por idosos, com o fim de discutir um percentual justo de reajuste dos seus planos de saúde? Qual a utilidade de se terem milhões de processos ajuizados por consumidores, com o objetivo de discutir a validade de cláusulas contratuais e de ser indenizados por cobranças abusivas? Qual a utilidade de se terem milhares de demandas individuais reivindicando o fornecimento de um medicamento, ou o pagamento de um beneficio devido a profissionais de certa categoria?

Tais demandas têm, via de regra, as mesmas características, ou seja, possuem uma mesma origem fática, ou seja, uma base fática que se não é idêntica é muito parecida, muitas vezes demonstradas por meio de documentos, ficando eventuais detalhes individuais para um momento seguinte, o que restringe a discussão central a questões fáticas ou de direito comuns, dando maior aproveitamento à atividade jurisdicional realizada e satisfazendo, portanto, o anseio por economia processual ${ }^{26}$.

Em face de tais circunstâncias, mostra-se desnecessário e nocivo o exercício repetido de julgamentos sobre direitos indivisíveis ou individuais homogêneos, já que tal

\footnotetext{
${ }^{25}$ Aluisio Gonçalves de Castro MENDES. “A legitimação, representatividade adequada e a certificação nos processos coletivos e as ações coletivas passivas." Revista de Processo,p. 255.

${ }^{26}$ BEDAQUE, op. cit. p. 50, nota 23. Segundo o autor: "Representa aplicação desse princípio o procedimento que possibilite alcançar os escopos da atividade jurisdicional com o máximo de eficácia e com o menor dispêndio de energia possível."
} 
repetição contradiz toda a lógica da eficiência, de se obter o máximo de resultado com o mínimo de esforço ${ }^{27}$, e não influencia positivamentea questão da segurança, sendo, aliás, preocupante, quando permite contradições lógicas nas decisões e a consequente quebra da isonomia.

Não será o uso da tutela coletiva que fará decair o nível de segurança no nosso sistema, mesmo porque esse tipo de tutela já está previsto no ordenamento, se mostrando essencial não só para os novos direitos, como para as novas realidades fáticas, massificadas e repetitivas.

Outrossim, a tutela coletiva não acarreta a redução das possibilidades de defesa, recurso ou de produção probatória, mantendo-se integras na dimensão coletiva, todas as garantias e direitos fundamentais que permeiam o processo individual, inspirado no devido processo legal.

Ao invés de gerar insegurança, o processo coletivo torna possível para milhares de indivíduos, a efetiva proteção de direitos de baixo valor econômico, desconhecidos, ou que jamais seriam protegidos pelo fato do cotidiano de muitas famílias brasileiras não permitir $^{28}$.

Dos aspectos ligados à efetividade processual, acima alinhavados com base nas lições de Barbosa Moreira, fica nítida, portanto, a possibilidade e a necessidade de se trabalhar conjuntamente, neste estudo, com a vertente da celeridade unida à vertente da maior abrangência subjetiva da tutela jurisdicional, de maneira complementar e não antagônica, como poderia se pensar, e sem desprezar a segurança que se espera de tal atividade, ligada a sua capacidade de reconhecer a versão mais próxima da realidade fática e alcançar a decisão mais compatível com o ordenamento jurídico existente.

Nesse contexto surge o processo coletivo, como um mecanismo que tem o mesmo objetivo primário do processo individual, de solucionar conflitos com base no direito, contudo, de uma maneira mais adequada aos novos conflitos e direitos que emergem na sociedade moderna, em relações jurídicas indivisíveis, cuja possibilidade da Jurisdição

27 Ibid., p. 50. Em sentido similar: José Carlos BARBOSA MOREIRA. "Notas sobre o problema da 'efetividade' do processo". Revista da AJURIS, p. 77-78. Ainda sobre a eficiência: Carolina Bonadiman ESTEVES. In: Suzana Henriques da COSTA (Coord). Comentários à Lei de Ação Civil Pública e Lei de Ação Popular,p. 347.

${ }^{28}$ José Carlos BARBOSA MOREIRA. "A efetividade do processo de conhecimento." Revista de Processo, p. 136; No mesmo sentido: ALEXANDER, Janet Cooper."An introduction to Class Actions Procedure in the United States”. Disponível em:http://law.duke.edu/grouplit/papers/classactionalexander.pdf, p. 1. 
atuar de maneira absolutamente individual se mostra impossível (como nas tutelas envolvendo o meio ambiente), ou em relações jurídicas individuais e divisíveis, mas com fatos tão massificadas e homogêneos (mesma origem) ${ }^{29}$, que comportam um julgamento coletivizado (como nas demandas em que se visa a anulação de uma cláusula de um contrato de adesão com a devolução de valores pagos a mais).

Nesse novo cenário, o processo coletivo converge com a ideia de efetividade, quando permite, por meio da concentração de milhares de demandas individuais numa única demanda coletiva, levar para milhares (às vezes milhões) de pessoas, a tutela de direitos indivisíveis ou de direitos individuais que sofrem violação em massa.

Por meio de um modelo coletivizado de processo, pode-se alcançar uma justiça mais rápida, justamente por se levar a atividade jurisdicional ao maior número de pessoas possível, com o mínimo de esforço, o que traduz a ideia de economia e eficiência, e proporciona uma amalgama das ideias de economia, abrangência, celeridade e eficiência.

A abrangência, para o estudo do processo coletivo, étambém um pressuposto de celeridade e eficiência, ou seja, é justamente pela capacidade da tutela coletiva levar a satisfação do direito ao maior número de pessoas possível, que se consegue uma justiça mais célere, porque se faz por meio de um processo o que se gastaria milhares de processos para sefazer, ou seja, se proporciona maior eficiência; contudo, a abrangência atende também a necessidade de se proteger direitos que jamais seriam protegidos, pelos fatos já conhecidos (baixo valor econômico, desconhecimento ou impossibilidade social) ${ }^{30}$.

Pode-se concluir assim, que além de proporcionar a proteção dos direitos para pessoas muito modestas ou sem informação, que jamais ingressariam em juízo senão como representadas numa demanda coletiva, às vezes porque o próprio valor econômico em discussão não justificaria tanto, o processo coletivo, pela técnica de molecularização das demandas, proporciona também maior economia processual, celeridade e eficiência, tudo por conta da abrangência que tem a tutela prestada coletivamente.

Não podemos esquecer, que a doutrina desde há muito já havia estabelecido um modelo geral correspondente ao que se deveria considerar um processo efetivo, modelo

\footnotetext{
${ }^{29}$ Sobre a definição dos direitos individuais homogêneos: MENDES, Aluisio Gonçalves de Castro. Ações coletivas no direito comparado e nacional,p. 225-227.

${ }^{30}$ José Carlos BARBOSA MOREIRA. "A efetividade do processo de conhecimento." Revista de Processo, São Paulo: Revista dos Tribunais, vol. 74, p. 126-137, 1994, p. 136; No mesmo sentido: ALEXANDER, op. cit. p. 1 , nota 28 .
} 
que passa pelos seguintes pontos: a) adequação dos instrumentos aos direitos; b) utilidade prática dos instrumentos, inclusive quando indeterminado ou indeterminável os sujeitos; c) aprimoramento da atividade probatória; d) capacidade das decisões de produzir os efeitos nelas anunciados e; e) capacidade de se alcançar os mesmo resultados com o mínimo dispêndio de tempo e energias ${ }^{31}$.

Também aqui, dos vetores de efetividade acima elencados, o último, relacionado à economia processual, possui total sintonia e convergência com as ideias que vem sendo construídas, uma vez que um dos objetivos contidos na utilização do processo coletivo é, justamente, proporcionar uma tutela mais abrangente em termos subjetivos, com o mínimo de gasto de tempo e recursos (um processo para milhares de situações), mas sem prejudicar o resultado da prestação jurisdicional para os sujeitos que serão afetados pela decisão coletiva, constituindo-se também, por conseguinte, como um instrumento adequado e útil.

Vê-se assim, que o ponto relativo à adequação dos instrumentos aos direitos existentes também permeia o estudo do processo coletivo, que além de especialmente voltado aos direitos indivisíveis, também é o mais adequado para os direitos de valor econômico individual ínfimo, cujas partes não têm estimulo de ingressar isoladamente em juízo, e também para os direitos ligados as pessoas mais frágeis ou mal informadas, que dependem do processo coletivo para terem acesso ao seu dia na corte.

Sedimentada a ideia de que o processo coletivo proporciona maior efetividade, tanto por meio da economia processual, concentrando num único litigio milhares de conflitos individuais (atuando com menos gasto de tempo e recursos), como também promovendo a proteção de direitos que muitas vezes jamais seriam tutelados, tem-se por imperioso concluir, que a coletivização de demandas individuais proporcionará uma ampliaçãodesses mesmos resultados, mostrando-se como medida adequada e necessária para a obtenção de um acesso à justiça substancial.

\footnotetext{
${ }^{31}$ Jose Carlos BARBOSA MOREIRA. "Notas sobre o problema da 'efetividade' do processo". Revista da AJURIS, p. 77-78. Igualmente: Carolina Bonadiman ESTEVE. In: Suzana Henriques da COSTA (Coord). Comentários à Lei de Ação Civil Pública e Lei de Ação Popular,p. 347.
} 


\section{A TECNICA DE COLETIVIZAÇÃO DE DEMANDAS INDIVIDUAIS}

A técnica de coletivizar uma demanda individual, nada mais é do que converter em coletiva uma demanda e, portanto, um processo, iniciado nos moldes dos processos individuais, o que se alcançaria por meio de uma decisão judicial, que seria precedida da participação de ambas as partes, teria necessariamente que abordar determinados pontos e poderia ser proferida, como regra, até antes de iniciada a instrução probatória ${ }^{32}$, como será visto mais adiante.

Tal decisão ser assemelharia àquela que admite uma demanda como coletiva, pois teria de examinar os pressupostos do processo em geral, bem como os específicos da tutela coletiva, mormente a espécie de direito coletivo lato sensu que seria ou se tornaria objeto do processo, definindo os fundamentos da demanda e os pedidos, bem como a extensão subjetiva da decisão (qual a classe abrangida).

A intimação do autor seria fundamental, tanto para cientificá-lo de que o direito por ele invocado é um direito indivisível (difuso ou coletivo stricto sensu), que teria de ser tratado mediante um modelo coletivo de processo, ou para informá-lo de que, apesar de individual, o direito reivindicado por ele possui a mesma origem que outros direitos, ou seja, são consequências de fatos muito semelhantes.

O autor poderia apresentar alguma objeção à coletivização de sua demanda, baseada no risco de atraso que seria causado a sua demanda individual, entretanto, sobre esta alegação caberá ao juiz decidir com base no caso concreto, para aferir a razoabilidade ou não da demora apontada pelo autor, que necessariamente deverá se fundar numa dilação processual significativa que não existiria no âmbito individual e que não poderia ser amenizada com as técnicas processuais existentes em nosso sistema.

Verificando o juiz, que realmente a coletivização da demanda individual prejudicará o autor originário, deverá refutá-la; contudo, verificando que não existe qualquer justificativa concreta para o suposto risco de atraso (como por exemplo, pela manutenção das mesmas provas que já seriam produzidas na situação individual, sem alteração do seu tipoou volume), ou que o atraso será ínfimo, podendo ser ainda minorado

\footnotetext{
${ }^{32}$ Curioso destacar que nos EUA a ação deve ser certificada como coletiva o quanto antes, mas pode ser modificada a qualquer momento, desde que antes da decisão final. Nestesentido: Joshua B. GRAY; Michelle H. SEAGULL. "Class Action Reaction: Amended Rule 23 Enhances Judicial Supervision in Class Litigation.”Antitrust, p. 92-93.
} 
pelo uso de medidas liminares, deverá ele converter a demanda individual em coletiva, analisando os demais requisitos.

A intimação do réu também é fundamental, por óbvio, em respeito ao contraditório e a ampla defesa, para que ele possa reagir e se manifestar sobre os aspectos do processo ligados a sua possibilidade de coletivização, ou seja, o réu tem que poder discutir se o caso envolve realmente um direito coletivo lato sensu (difuso, coletivo stricto sensu ou individual homogêneo), qual a extensão dessa classe e da sua pretensão.

Uma questão interessante que poderia ser suscitada pelo réu, concerne à numerosidade da classe e a comunidade dos seus interesses, ou seja, se a classe é suficientemente grande, para justificar a predominância do modelo coletivo sobre o individual no caso concreto, e se os interesses envolvidos são efetivamente indivisíveis ou, sendo divisíveis, se são oriundos de um fato comum, que não deve ser idêntico, mas semelhante.

Nesse momento, mostra-se profundamente desafiador o dever judicial de fundamentar a conversão de um único caso individual num processo coletivo, porque ele deverá estabelecer critérios que justifiquem a sua decisão, ou seja, que justifiquem a identificação do direito em questão como sendo um direito indivisível ou individual homogêneo, e justifiquem a conclusão pela necessidade de uso do método coletivo de solução de conflitos, ao invés do individual.

Este último ponto é o mais difícil, principalmente pelo fato de se tratar de uma demanda individual, na maioria das vezes desacompanhada de qualquer alegação e prova direta sobre a existência de uma classe numerosa na mesma situação.

Para tanto, não precisará o juiz se fundar necessariamente, por exemplo, na existência de outros casos similares no mesmo juízo, nem mesmo em outros órgãos do judiciário, já que estes não são requisitos de admissão de uma demanda coletiva, estando normalmente ligados às técnicas de uniformização jurisprudencial, recursos repetitivos, elaboração de súmulas ou de julgamento imediato do pedido, técnicas que de alguma forma se aproximam duma dimensão processual coletivizada, mas não se confundem, por não haver a extensão da decisão para todas as pessoas na mesma situação, atingindo, quando muito, apenas aquelas que levaram a questão ao Judiciário.

Assim como numa demanda coletiva, para o juiz decidir num caso individual concreto, que se trata de um direito indivisível ou individual homogêneo que atinge um 
número suficiente de pessoas, convertendo a demanda individual em coletiva, deverá ter a possibilidade de constatar que existem indivíduos em número significativo em situação jurídica similar a da parte, conclusão que ele alcançará com base nas alegações, nas provas dos autos e, principalmente, com base em máximas de experiência, conforme será visto em tópico especifico.

É certo, que nos casos de direitos indivisíveis, a constatação desta característica será aferida pela simples descrição do objeto que se pretende tutelar, na peça inicial, entretanto, nos casos de direitos individuais homogêneos, cujos objetos são divisíveis, a constatação da existência de outros direitos similares em número suficiente a justificar a coletivização da demanda transcenderá as afirmações fáticas e probatórias, para, com base na experiência comum, se concluir pela numerosidade de pessoas na mesma situação.

Aliás, ainda que se trate de direito indivisíveis, serão importantes as máximas de experiência, para se concluir se o direito é compartilhado por pessoas em número suficiente que justifique o processo coletivo; não se mostrará necessário o processo coletivo se a questão envolver poucas partes, sendo mais pertinente nesta hipótese o litisconsórcio necessário.

Será com base naquilo que normalmente acontece, que o juiz deverá concluir pela existência ou não de direitos individuais com origem comum a do direito em litígio, ou pela existência de codetentores de uma mesmo direito, em número suficiente a justificar o uso do processo coletivo.

Não será necessário, que haja alegação ou pedido nesse sentido, por razões óbvias, já que se trata de uma demanda originariamente individual ou pseudoindividual ${ }^{33}$, com causa de pedir e pedidos realizados sob o molde individual, mas que pode ter o julgamento estendido para beneficiar a todas as pessoas na mesma situação, mediante técnica parecida com o que ocorre nos casos de uniformização jurisprudencial, recurso especial repetitivo ou sumula vinculante, mas por meio de uma decisão coletiva, que beneficiará a todos direitos individuais comuns àquele direito, tornando desnecessários milhares de processos repetitivos.

33 A expressão "pseudoindividuais" foi originariamente criada pelos autores ADA PELLEGRINI GRINOVER e KAZUO WATANABE, e empregada por este último em: "Relação entre demanda coletiva e demandas individuais". In:Ada P. GRINOVER, Aluisio G. de C. MENDES e KazuoWATANABE (Coord.). Direito processual coletivo e o anteprojeto de código brasileiro de processos coletivos, p. 158-159. 
Também não deverá se exigir prova cabal sobre a numerosidade da classe de indivíduos representados, para se demonstrar a necessidade do processo coletivo em detrimento do individual, por razões semelhantes, já que o autor não terá essa preocupação inicial e, mesmo que tivesse, seria muito difícil dispor de material farto e suficiente, sendo mais provável que o réu disponha dessas informações e seja obrigado a fornecê-las, quando o Judiciário entender necessário.

De todo o modo, parece-nos natural que o juiz tenha condições de avaliar a situação concreta narrada na inicial e, com base naquilo que normalmente acontece na sociedade em que ele vive e exerce o seu oficio, decidir sobre a provável existência de situações similares que justifiquem o prestígio ao modelo coletivo, ainda que não trazidas até o momento ao crivo do Judiciário, ou sobre a existência de numerosos codetentores do mesmo direito; a existência de casos similares num mesmo juízo ou no Judiciário como um todo, naturalmente, servirá como um bom argumento, mas apenas isto.

Quanto à legitimidade, esta não deverá, ou pelo menos não deveria ser um óbice a tal conversão, porque, na pior das hipóteses poderia ser notificado um dos entes legitimados para que a assumisse a ação, em litisconsórcio com o autor originário ou não, sanando a irregularidade existente, exigência que não tem a nossa simpatia, por restringir o acesso ao processo coletivo e ser absolutamente desnecessária e sem razoabilidade, conforme se verá em tópico especifico, no qual são abordados diversos fundamentos para a legitimação individual em âmbito coletivo, especialmente o fato de o Ministério Público (um dos entes legitimados pela lei) ter de participar de toda demanda coletiva, ao menos como custus iuris, e o fato da coisa julgada apenas atingir os direitos individuais para beneficiá-los.

Desse modo, diante de uma demanda, por exemplo, que verse sobre a nulidade de clausulas num contrato de adesão envolvendo um serviço considerado essencial, prestado por uma empresa que notoriamente possui milhares de clientes, pois possui extensão nacional e farta publicidade nos meios de comunicação, poderá o juiz converter essa demanda individual em coletiva, de modo que toda a classe de consumidores que firmaram o referido contrato seja beneficiado pela decisão.

Esse raciocínio se aplica a milhares de situações envolvendo outros tipos de direitos, como direito sociais ligados à distribuição de medicamentos, ao pagamento de vantagens a servidores ou empregados, ao ressarcimento de danos e outros, onde o juiz, diante de um caso individual, com o qual provavelmente se identifica um grupo 
significativo de pessoas, inserido num contexto fático muito semelhante, poderá coletivizar a tutela jurisdicional, para que os efeitos positivos dessa pretensão sejam estendidos a todos representados na mesma situação, sem que os mesmos precisem comparecer ao Judiciário, a não ser para liquidar e executar, quando necessário.

Percebam que a extensão sobre os direitos individuais da classe representada se dará com relação apenas aos efeitos positivos, não havendo risco de prejuízo a direitos individuais, como será visto e repetido mais adiante e $^{34}$.

Assim, por exemplo, numa ação por meio da qual um servidor reivindica o pagamento de uma vantagem, o juiz poderá converter a ação individual em coletiva, para que ao final, a Fazenda Pública seja compelida a pagar a vantagem para todos os servidores da mesma categoria, mesmo que não entrem com demandas individuais; caso não seja efetuado o pagamento, que seja liquidada e executada individualmente a sentença coletiva, pelos servidores que tiveram seu direito individual homogêneo reconhecido.

Como dito, tal técnica proporciona significativa econômica processual, dispensando o ajuizamento de centenas de processos muito parecidos, onde serão aplicados o mesmo raciocínio judicial, alterando-se, apenas e quando muito, os valores a serem pagos.

Esse mecanismo, que se aproxima de uma uniformização jurisprudencial, mas feita em primeira instância e com o potencial de beneficiar pessoas que sequer entraram com processos individuais, pode ser repetido em demandas, por exemplo, que versem sobre a nulidade de uma cláusula num contrato de adesão e a correspondente ilegalidade da cobrança baseada em tal cláusula.

Convertida uma ação dessas em coletiva, a sentença deverá ser obedecida para todos os consumidores da mesma situação, sob pena de multa, ainda que estes não tenham ingressado em juízo, cabendo a cada um liquidar e executar individualmente caso o réu desobedeça o comando coletivo.

Por meio dessa técnica as decisões judiciais ganham mais autoridade e coerência, já que as divergências diminuem e as partes passarão a cumprir a decisão para todos os indivíduos na mesma situação, em obediência a isonomia, inerente à qualquer sistema democrático, independentemente de processos individuais, que tanto oneram o Judiciário e a sociedade, com processos repetitivos e desnecessários, que entopem as estrutura físicas,

\footnotetext{
${ }^{34}$ Ada Pellegrini GRINOVER; Linda MULLENIX; KazuoWATANABE. Os processos coletivos nos países de civil law e common law: uma análise de direito comparado. p. 305-306.
} 
ocupam os servidores e consomem os recursos para resolver de maneira atomizada, problemas que são típicos de relações jurídicas homogêneas, ignorando a possibilidade de uni-los num único julgamento, como se isto já não ocorresse por outras vias e com outros contornos. 


\section{A DECISÃO QUE PODERIA TRANSFORMAR UM PROCESSO INDIVIDUAL EM COLETIVO}

\subsection{Os pontos que necessariamente serão abordados nessa decisão}

Como visto, a técnica proposta nesta tese nada mais é que o uso de uma decisão judicial com o objetivo de transformar uma ação que nasceu no formato individual, numa demanda coletiva, que espraie seus efeitos positivos sobre todos os indivíduos naquela situação, dispensando o ajuizamento das respectivas ações individuais ou, pelo menos, tornando muito mais célere o percurso dos indivíduos no Judiciário, que poderão liquidar e executar seus direitos subjetivos imediatamente.

Ainda, no caso de direitos indivisíveis, a coletivização, conforme será visto com mais acuidade em tópico especifico, terá o escopo de proporcionar o fim dos conflitos entre coisas julgadas incompatíveis na prática (problema que a técnica de coisa julgada secundumeventum litis não resolve integralmente), além de poder beneficiar os indivíduos com a técnica de ampliação objetiva (extensão in utilibus), por meio da qual o individuo pode liquidar e executar direitos individuais que sejam relacionados com o direito coletivo tutelado $^{35}$.

Nesse contexto, deve-se ter muito cuidado com o principal instrumento utilizado pela técnica ora proposta, ou seja, com a decisão judicial, fazendo-se imperiosa a demarcação de exigências e limites, para que ela não se traduza em abuso e em prejuízo para a sociedade.

As exigência substanciais que deverão ser observadas concernem especialmente ao conteúdo necessário numa decisão desta natureza; não há como estudarmos uma técnica sem entendermos o que necessariamente os instrumentos utilizados pretendem e como eles propiciarão tal resultado.

\footnotetext{
35 Ibid., p. 305. Segundo o autor: "Fenômeno importante a ser sublinhado, neste tópico, é o do aproveitamento da coisa julgada coletiva para beneficiar as pretensões individuais. Desde que os danos individuais decorram dos mesmos fatos que fundamentaram a demanda coletiva, há com que uma ampliação objetiva do objeto litigioso do processo coletivo para se entender que, na sentença condenatória coletiva, está contida também a condenação à indenização pelos danos individuais, constituindo a sentença coletiva, bem por isto, titulo executivo também no plano individual."
} 
Nem podemos imaginar que uma decisão judicial, que coletivize uma demanda individual, possa ignorar alguns pontos que se fazem presentes na análise da admissibilidade de demandas coletivas e que, portanto, terão de ser examinados quando se pensar na conversão de uma ação em coletiva.

Dessa maneira, identificamos alguns assuntos que a decisão judicial usada para converter um processo individual em coletivo terá que enfrentar necessariamente, a fim de reduzir os riscos de equívocos e danos, sendo esses os seguintes: legitimidade, espécie de direito coletivo, necessidade do modelo coletivo, delimitação da classe, do pedido e dos fundamentos.

A legitimidade está presente nos entes expressamente indicados na legislação pátria, especialmente a LACP e o CDC, mas se imaginarmos possível a legitimidade individual, como nos parece fundamental, esta traduzirá a ideia de pertinência subjetiva da ação, de modo que a parte autora esteja inserida na relação jurídica trazida na inicial e se diga detentora do direito pleiteado ${ }^{36}$.

Esta exigência, denominada na legislação norte-americana de tipicidade, é fundamental para que os representados tenham um representante minimante interessado e comprometido com a busca por um resultado positivo ${ }^{37}$.

Ademais, não há porque se autorizar um indivíduo estranho a litigar em prol de uma classe na qual ele não esteja inserido, se todos os membros dessa classe tem legitimidade para tanto, havendo ainda entes institucionais com essa mesma função.

Confirmada a legitimidade da parte para uma demanda coletiva, o juiz deverá analisar se o direito alegado pela parte refere-se a uma relação indivisível (difuso ou coletivo stricto sensu) ou se se trata de um direito individual, mas com origem comum em relação a outros prováveis direitos.

Em se tratando de um direito indivisível trazido em juízo por uma demanda pseudoindividual, caberá a identificação desse direito e sua fundamentação; se difuso, deverá ficar expressa a circunstância fática que une os codetentores desse direito

\footnotetext{
${ }^{36}$ Sobre a legitimidade ad causam: Enrico Tulio LIEBMAN. Lezionididirittoprocessualecivile, p. 24-25.

${ }^{37}$ Charles DONELAN. "Prerequisites to a Class Action Under New Rule 23.”10 B.C.L. Rev. p. 534, Disponível em: http: //lawdigitalcommons.bc.edu/bclr/vol10/iss3/6.
} 
indivisível; se coletivo stricto sensu, deverá ser consignada na decisão qual relação jurídica existe entre a classe ou entre seus membros e a parte contrária ${ }^{38}$.

Em se tratando de um direito individual, mas que possua origem comum em relação a outros prováveis direitos, o juiz terá de cumprir a função hercúlea de demonstrar essa probabilidade, argumentando com base em demandas existentes em seu juízo, no Judiciário como um todo, ou mesmo com base em máximas de experiência, que permitam ao juiz alcançar conclusões calcadas naquilo que normalmente acontece.

Como visto acima, não é requisito para que se caracterize um direito individual como homogêneo, a existência de demandas similares no Judiciário (requisito que se aproxima mais da ideia de uniformização jurisprudencial).

Normalmente a caracterização de um direito como coletivo é pretendida pela própria parte autora, que argumenta neste sentido na inicial e demonstra minimamente as suas alegações, cabendo ao juiz concluir pela probabilidade de tais direitos sem exigir prova incontestável sobre o número de pessoas na mesma situação, mesmo porque em muitos casos essas provas só podem ser apresentadas pelo réu.

Como a hipótese ora estudada é de o juiz transformar uma ação individual em coletiva, a conclusão sobre a homogeneidade do direito individual trazido pela parte terá de ser auferida pelo juiz sem que o autor tenha feito tal afirmação.

Para tanto, ele irá analisar a relação jurídica existente entre autor e réu, e em seguida avaliará a probabilidade, com base naquilo que normalmente acontece, de situações similares aquelas se repetirem com inúmeros indivíduos.

Ao final desse processo analítico argumentativo, poderá concluir ou não pela homogeneidade do direito em questão em relação a outros que ainda não foram levados em juízo, estendendo, portanto, os efeitos de uma eventual sentença de procedência, para beneficiar a todos.

O processo, como um instrumento público que visa ao alcance de escopos sociais, políticos e jurídicos ${ }^{39}$, não deve servir somente aos interesses das partes nem deve ter a extensão da sua eficácia definida pelos particulares, ao menos quando a ampliação dessa

\footnotetext{
${ }^{38}$ Sobre a conceituação de direito difuso e coletivo stricto sensu ver: Aluisio Gonçalves de Castro MENDES. Ações coletivas no direito comparado e nacional,p. 213-224.

${ }^{39}$ Candido Rangel DINAMARCO. A instrumentalidade do processo, p. 214-215.
} 
eficácia puder beneficiar a um sem numero de pessoas, sem prejudicar as partes originárias, evitando que entrem em juízo ou abreviando o caminho delas.

O beneficio da sociedade e do próprio Judiciário, com a racionalização da sua atividade pública, não pode ficar sujeito ao alvedrio dos indivíduos, principalmente quando nenhuma garantia de liberdade se obtém com tal apatia, mas apenas se dificulta a atuação de uma atividade que tem por fim a premissa para sermos efetivamente livres: a proteção dos direitos.

Ultrapassados esses pontos, agora chega o momento do juiz avaliar se o processo coletivo se mostra necessário, ou seja, se a situação pode ser resolvida no modelo individual, com o litisconsórcio necessário (no caso de direitos indivisíveis) ou facultativo (no caso de direitos individuais).

Não há, nem mesmo no direito norte-americano, um número mínimo de participantes que nos autorize afirmar genericamente sobre a necessidade de utilização do modelo coletivo em lugar do individual com litisconsórcio, dependendo do caso ${ }^{40}$.

Também não se mostra útil e seguro, que a lei fixe um número mínimo, pois os fatos sociais possuem uma dinâmica que a legislação não pode acompanhar, ficando o Judiciário incumbido de dar a norma o sentido mais atual e pertinente possível.

Nesse sentido, em se tratando de um direito indivisível, deverá o juiz se questionar se seria possível a presença no processo de todos os litisconsortes necessários; constatada a inviabilidade, pelo número excessivo de partes que isso geraria, deverá haver a conversão.

O número excessivo será definido pelo juiz do caso, levando-se em conta as particularidades da causa, o local onde o processo tramita, o procedimento a ser utilizado, as fases e atos processuais que terão de ser respeitados e a possibilidade de todos exercerem igualmente seu direito de defesa.

Em se tratando de um direito individual homogêneo, caberá ao juiz se questionar sobre a existência de um numero razoável de pessoas em situação semelhante, ou seja, com demandas similares a serem levadas ao Judiciário.

Se o número for insignificante, deverá ser dada preferência ao modelo individual, contudo, entendido pelo juiz que se trata de uma situação abrangente, que envolve um número razoável de pessoas, deverá ele concluir pela utilidade do processo coletivo, que

\footnotetext{
${ }^{40}$ DONELAN, op. cit. p. 531 , nota 37.
} 
tornará dispensável ou pelo menos mais breve, futuras demandas individuais pretendendo coisas muito parecidas.

Para decidir sobre esse ponto, o juiz levará em conta, aspectos diferentes dos mencionados acima, pois se não for cabível a tutela coletiva dos direitos individuais, cada individuo poderá buscar o seu sem precisar de se reunir em litisconsórcio.

Desse modo, o juiz não só se preocupará com a inviabilidade de todos se juntarem numa mesma demanda, mas sim com a multiplicação desnecessária de demandas com causa de pedir e pedidos muito parecidos, mormente no que tange ao fundamento jurídico, que poderiam se resumir no julgamento de uma única demanda que representasse todas as demais.

Sendo assim, a pergunta que o juiz deverá responder é: a coletivização será útil para evitar ou abreviar o julgamentode um número relevante de processos em juízo? Para tanto, deverá ele considerar a dificuldade que o Judiciário terá para julgar todas as potenciais demandas similares que eventualmente seriam propostas, bem como as dificuldades inerentes a um processo coletivo, que pode ser ineficaz no caso de improcedência.

Ultrapassadas todas essas questões, caberá ao juiz definir a respectiva classe de indivíduos representados, o pedido a ser examinado em seu favor e os seus fundamentos.

Como não houve indicação de classe alguma na petição inicial, caberá ao juiz, analisando os fatos e percebendo a existência de um direito coletivo lato sensu, definir um grupo de pessoas ao qual será direcionada a tutela jurisdicional coletiva.

Assim, por exemplo, numa demanda pseudoindividual reivindicando direito difuso, o juiz deverá indicar o grupo de pessoas afetado, podendo ser os moradores de determinada região ou os consumidores de determinados produtos.

Em se tratando de direito coletivo stricto sensu, haverá um grupo de pessoas que possui uma relação jurídica base entre si, como por exemplo: membros associados de uma instituição, ou com a parte contrária, como por exemplo: grupo de trabalhadores de determinada empresa.

Já no caso de direito individuais homogêneos, o que permite a definição da classe é a homogeneidade dos fatos, ou seja, o grupo de pessoas atingido pela decisão será composto por indivíduos que tenham o direito similar ao reconhecido na sentença, em decorrência de fatos muito parecidos. 
Nesses casos, a demanda poderá abranger a todos os consumidores de um produto, a todas as vitimas de um evento ou a todos servidores que ocupem um determinado cargo e exerçam a respectiva função.

Feita a indicação da classe, caberá especificar o pedido e a causa de pedir. No caso de direitos indivisíveis deverão ser distinguidas quais causas de pedir correspondem a esse direito e como ele se encontra reivindicado, sendo que, pela indivisibilidade do objeto, coletivizada ou não a demanda os efeitos da tutela se espraiarão por toda a classe, tendo a coletivização o beneficio de impedir conflitos práticos para as hipóteses em que a coisa julgada secundumeventum litis não resolveria, além da extensão in utilibus em beneficio dos indivíduos que compõem a coletividade, pela ampliação do objeto da demanda.

Em caso de direito individuais homogêneos, o pedido que terá sua eficácia coletivizada deverá ser distinguido também, assim como a causa de pedir que lhe seja concernente, o que se mostra fundamental para que se possa examinar a homogeneidade do direito em relação a outros.

\subsection{A análise da representatividade adequada}

Na legislação atual não há dispositivo legal que permita ao Judiciário, realizar o controle da adequação da representação desempenhada pelo autor de demanda coletiva, ao contrário do que ocorre nos E.U.A, onde a rule 23 prevê expressamente, dentre os prerequisites para a propositura de demanda coletiva, a necessidade de tal controle ${ }^{41}$.

Nesse rumo, a doutrina norte-americana estabelece alguns critérios que permitem uma análise objetiva da adequação do representante, ligados principalmente às características do escritório que atuará na defesa do representante da coletividade, devendo possuir condições financeiras de custear as despesas de uma demanda coletiva, tais como relacionadas às provas ou as notificações individuais necessárias, e experiência bem

\footnotetext{
${ }^{41}$ Charles R. FLORES. "Appealing Class Action Certification Decisions Under Federal Rule Of Civil Procedure 23(F)," Setton Hall Circuit Review, p. 04. Disponível em: http://erepository.law.shu.edu/circuit_review/vol4/iss1/2. No Brasil, alguns autores entendem que cabe ao Judiciário controlar a representatividade adequada, quando necessário, por exemplo, o exame da pertinência temática. Sobre o assunto ver: Suzana Henriques da COSTA. In: "A representatividade adequada e litisconsórcio: o projeto de lei 5.139/2009." In: Petronio CALMON; Mirna CIANCI; et al (Coord.). Em defesa de um novo sistema de processos coletivos: estudos em homenagem a Ada Pellegrini Grinover, p. 630-631. Em sentido contrário, falando que a representatividade adequada aqui ocorre ope legis, posicionamento com o qual concordamos: Pedro da Silva DINAMARCO. Ação Civil Pública, p. 201.
} 
sucedida nesse segmento, com boas atuações já desempenhadas em demandas coletivas anteriores $^{42}$.

No direito pátrio a legitimidade é outorgada automaticamente pela lei, que estabelece os entes legitimados como presumidamente aptos à representação, deixando como únicas hipóteses de análise do magistrado, aquelasrelativas à pertinência temática, ao prazo de constituição da associação,ou ainda, quando a associação não possua mais de um ano de estabelecimento, mas veicule pretensão de relevância social.

Não obstante a aparente omissão do direito brasileiro, pensamos que ela não se encontra equivocada, já que não concordamos com a hipótese de se inadmitir uma ação coletiva, pelo fato do autor ou o seu patrono não ter condições de custear as despesas da demanda, não ter experiência com demandas coletivas anteriores ou ter sofrido derrotas nessas demandas.

Não concordamos com a análise da adequação da representatividade lastreada num aspecto econômico, pois entendemos que a gratuidade de justiça é um direito fundamental do individuo, como previsto em nossa Constituição, não sendo admissível a discriminação de pessoas ou profissionais pelas condições financeiras que possuem.

Ademais, pensamos que quando se restringe a admissão de demandas coletivas para pessoas ou escritórios com recursos para suportá-la, estamos sim discriminando aqueles que não têm condições financeiras, pois estamos a impedir igualdade de oportunidades no acesso a um serviço publico essencial ao ser humano, ao seu núcleo de liberdade e dignidade, e ao próprio modelo democrático de Estado que possuímos.

O fato da questão não ser entendida assim no E.U.A não significa que estejamos errados ou certos, já que vivemos em culturas e sistemas jurídicos bem diferentes, com valores que nem sempre confluem ou são compreendidos com o mesmo sentido.

No que tange a restrição baseada em experiências pretéritas bem sucedidas, também pensamos que ela acarretauma desigualdade de oportunidades, principalmente se pensarmos que ela impede o profissional que nunca trabalhou numa demanda assim, de ter a sua primeira oportunidade sozinho, subordinando-o a atuação num escritório com outros profissionais que tenham experiência prévia.

\footnotetext{
42 Charles DONELAN. "Prerequisites to a Class Action Under New Rule 23.”10 B.C.L. Rev. p. 535, Disponível em: http: //lawdigitalcommons.bc.edu/bclr/vol10/iss3/6.
} 
Outrossim, presumir que o profissional derrotado em outras demandas coletivas, não teria a capacidade de tocar uma outra mostra-se também completamente equivocado, mesmo porque a derrota não deveria decorrer da leniência da profissional, mas sim da falta de fundamento jurídico suficiente, situação que nem sempre irá se repetir; pensar o contrário seria impor ao cidadão uma pena perpetua, um óbice intransponível ao exercício da sua atividade profissional.

Percebe-se assim, que essa visão da representatividade adequada cria uma restrição ao acesso à justiça, na nossa ótica inadequada, pois não se pode presumir que a ausência de experiência ou experiências negativas tornem o profissional inapto à representação da coletividade, além de desnecessária, pois a participação do Ministério Público será obrigatória e se acrescenta a inúmeras outras garantias voltadas a proteção dos direitos individuais envolvidos.

Como será visto no capítulo 11, nos E.U.A. a preocupação com a representatividade adequada pode ser mais justificável, principalmente pelo regime de coisa julgada de lá, que sempre afeta a todos, a não ser os que exercerem o opt out nos casos em que seja possível.

Contudo, no Brasil a coisa julgada nunca prejudicará direitos individuais, e os difusos ou coletivos stricto sensu, somente se a sentença de improcedência se fundar nas provas dos autos, de modo que a incapacidade do indivíduo em representar a classe, ainda que pudesse ser aferida pela situação econômica ou profissional da parte ou do seu advogado, não trará prejuízos à sociedade.

Conclui-se assim, ser desnecessária uma análise da adequação do representante da coletividade, seja por considerarmos discriminatórios os critérios existentes no direito comparado, provenientes do direito norte-americano, seja por considera-los desnecessários, já que o processo coletivo também e passível de tramitar sob o beneplácito da justiça gratuita, sem poder prejudicar direitos individuais e sob o acompanhamento do Ministério Público, não se podendo afirmar a inaptidão de um profissional com base apenas na sua falta de experiência ou em experiências anteriores negativas.

Em verdade, a representatividade adequada deverá ser analisada juntamente com a boa-fé processual da parte, que não pode formular pretensão sabidamente improcedente, ou com base em fatos que nunca ocorreram, que tenham objetivos espúrios ou sem nenhum fundamento jurídico. 


\subsection{A identificação de um direito como individual homogêneo ou indivisível, da utilidade da tutela coletiva e a importância das máximas de experiência}

Como dito acima, a conclusão a respeito da homogeneidade ou não de um direito individual não necessita de uma demonstração cabal e incontestável, de que existem inúmeros outros direitos decorrentes de fatos muito parecidos, mesmo porque estamos falando de uma técnica de coletivização de demandas individuais, que irá se deparar com petições iniciais que nada mencionam sobre a existência de situações homogêneas.

Desse modo, a conclusão sobre a homogeneidade do direito em concreto dependerá de uma constatação baseada no quod plerumqueaccidit, ou seja, naquilo que normalmente acontece ${ }^{43}$.

O Código de Processo autoriza a utilização das máximas de experiência quando não houver regra legal particular sobre provas, contudo, a doutrina fala da sua utilização sempre que não houver prova direta sobre uma alegação, pois nestes casos, será necessário um exercício de presunção, que dependerá do conhecimento de um fato secundário, mediante indícios, ou seja, uma prova indireta para se concluir sobre a veracidade da alegação da parte ${ }^{44}$.

Assim, por exemplo, quando se alega o sofrimento de um dano, sem se dispor de uma prova direta, qual seja: uma filmagem ou uma testemunha ocular, qualquer conclusão sobre a veracidade de tal alegação terá de se calcar em indícios.

\footnotetext{
${ }^{43}$ Michele TARUFFO. "Senso comune, esperienza e scienzanelragionamentodelgiudice". In:Sui confini:scrittisullagiustiziacivile, p. 140. Segundo o autor: "Secondoladefinizionedi Stein, chevieneripetuta da tuttaladotrina sucessiva, lamassima d'esperienzaè una regolageneralechevienecostruitainduttivamentesulla base dell'esperienza relativa a determinatistatidi cose." No mesmo sentido: Michele TARUFFO. "Funzionedella prova: lafunzionedimostrativa." In: Sui confini: scrittisullagiustiziacivile.p. 312. Neste artigo MICHELE TARUFFO apresenta uma lucida lição sobre o assunto, ensinando que: "Il concettodimassima d'esperienza, come regolageneralederivataappunto per via indutiva dall'esperienzadell'id quod plerumqueaccidit, aveva una funzione bem precisa, ossiaqueladifondare um modelo silogístico dedutivo delgiudiziodi fato.” Ver também: Candido Rangel DINAMARCO. Instituições de Direito Processual Civil. Vol. III, p. 122.

${ }^{44}$ Para DANILO KNIJNIK, as máximas de experiência se mostram úteis também nos casos de prova direta, pois para ele todo juízo fático seria uma inferência a partir de regras decorrentes da experiência comum, o que não concordamos, mas serve para demonstrar que a máxima de experiência serve para o alcance de presunções. Danilo KNIJNIK. A prova nos juízos cível, penal e tributário, p. 68-70. Sobre o uso das máximas de experiência para o alcance de presunções simples, ver também: Eduardo CAMBI. A prova civil: admissibilidade e relevância.p. 284.
} 
Seguindo no exemplo, sealegado que o dano foi decorrente de um atropelamento e o carro do réu encontra-se abalroado em local e forma compatível com a do acidente, e manchado de sangue,pode-se presumir que ele atropelou alguém.

No caso, o indicio será sempre associado a uma máxima de experiência, que permita alcançar a presunção, de modo que, se eu tenho prova do dano sofrido pela vítima e pelo veiculo, eu poderei presumir a veracidade da alegação, se eu partir da premissa (ou máxima de experiência) de que o carro batido e manchado de sangue indica a ocorrência de um atropelamento.

Percebe-se então, que por meio das máximas de experiência nós elaboramos regras gerais não previstas na lei, extraídas da experiência comum e universal, para presumirmos algo com base em provas indiciárias.

Na hipótese ora vertida, de coletivização de uma demanda individual pela presunção de que aquele direito em concreto se identifica com inúmeros outros, que ainda não foram levados ao Judiciário, apesar de faltar alegação que permita alcançar tal generalização, os fatos narrados e as provas apresentadas podem indicar o caminho.

Isto porque, as provas do caso individual servirão como indícios de que outras situações similares envolvendo outras pessoas vêm ocorrendo, apesar delas só proporcionarem certeza sobre os fatos individuais, desde que, associadas às máximas de experiência, o juiz possa alcançar tal conclusão.

Destarte, se um consumidor ingressa com uma demanda contra uma grande empresa de âmbito nacional, afirmando ter assinado um contrato de adesão para o fornecimento de serviços tidos hoje como essenciais (plano de saúde, serviços de crédito, telefone e outros), e que no referido pacto existem cláusulas nulas por serem abusivas, poderá o juiz pressupor, com base na experiência de que a respectiva empresa possui milhares de clientes pelo país afora e de que os serviços fornecidos são comuns em grande parte dos lares brasileiros, que se trata de um direito individual homogêneo.

Da mesma forma, alegado por uma parte que ocupa um determinado cargo, o desrespeito a determinados direitos, dependendo do cargo poderá o juiz presumir, pela natureza do serviço desempenhado, por exemplo, que existem dezenas de outras pessoas em situação similar, a ponto de justificar a coletivização da demanda individual ou pseudoindividual. 
Importante salientar apenas, que o juiz deverá, além de obedecer todos os pontos fundamentais acima mencionados, fazer constar na decisão, quais indícios e qual máxima de experiência permitiu-lhe presumir se tratar de um direito individual homogêneo.

Insatisfeito o réu com a decisão, poderá recorrer para a instância superior, discutindo os indícios e a máxima de experiência utilizada pelo Judiciário. Caso ele pretenda produzir provas sobre a questão, deverá aguardar a fase instrutória e convencer o juiz pela utilidade da prova testemunhal ou pericial, pois as provas documentais deverão vir com a manifestação prévia sobre a possibilidade de coletivização.

Importante salientar, por fim, que todas as considerações tecidas por ora a respeito da caracterização da homogeneidade do direito deverão ser estendidas para a caracterização da necessidade do processo coletivo, ou seja, para aferição da numerosidade da classe, que justifique a coletivização de demandas versando sobre direitos indivisíveis ou individuais homogêneos.

Também neste ponto, muitas vezes não haverá como se exigir prova cabal da numerosidade da parte a ponto de justificar o modelo coletivo, de modo que, novamente, os indícios contidos nos autos, aliados a experiência comum, poderão contribuir, como nos exemplos acima mencionados, que servem para ilustrar não apenas a presunção de homogeneidade, como também a presunção de numerosidade suficiente para justificar a técnica coletiva de resolução de conflitos, tanto nos casos de direitos individuais homogêneos, como nos casos de direitos indivisíveis, que se não envolver muitos indivíduos, deverá ser resolvido em processo individual, pela técnica do litisconsórcio necessário.

\subsection{A imprescindibilidade do contraditório prévio e o momento limite para a coletivização}

Além das constatações feitas acima, a respeito da decisão que converte uma demanda individual em coletiva, deve-se adicionar o dever de se oportunizar o exercício do contraditório prévio a ambas as partes, já que o autor pode apresentar razões que justifiquem o prosseguimento da demanda como individual, assim como o réu. 
O autor pode entender que a coletivização de uma demanda individual que trate de direitos individuais homogêneos, pode gerar um retardamento muito grande ao processo, em virtude do aumento no número ou na complexidade das provas e demais atosa serem produzidos.

É importante destacar, que caberá sempre ao juiz a decisão final, devendo a parte apontar um prejuízo em concreto, ou seja, alguma situação em concreto que será gerada na via coletiva, mas que seria completamente dispensada na via individual, e imporia ao processo uma demora significativa.

Impende salientar ainda, que eventual demora, se não for exagerada, poderá ser superadas pelo uso de medidas liminares, desde que presentes os respectivos requisitos, como a tutela antecipada, que impeçam a ocorrência de danos irreparáveis ou a espera desnecessária para o acesso ao direito.

Destaca-se ainda, que em se tratando de direito indivisíveis, a alegação de que a coletivização da demanda geraria atraso e prejuízo também poderá ser oferecida, mas dificilmente prosperará, já que a coletivização nesses casos representaria pouquíssima ou nenhuma alteração em relação à causa de pedir e ao pedido.

Nesse tipo de situação, ao autor caberá discutir se realmente o caso em concreto envolve um direito indivisível e se esse direito não poderia ser objeto de um processo individual, com a necessária participação dos litisconsortes.

Nesse diapasão, o réu terá amplitude de argumentação similar, tanto na hipótese de direito indivisível como na hipótese de direito individual homogêneo.

$\mathrm{Na}$ primeira, envolvendo direito indivisível, pela própria natureza do direito o processo coletivo somente será evitado se demonstrado que não se trata de um direito indivisível ou, do contrário, que o processo coletivo é desnecessário, sendo plenamente viável o litisconsórcio necessário.

Na segunda hipótese, não poderá o réu alegar que a conversão de demanda envolvendo direito individual homogêneo gerará mais atraso ao julgamento e a resolução da lide, pois o principal onerado com o tempo num processo judicial é o autor, que, se tiver concordado com a coletivização ou não tiver apresentado qualquer situação em concreto que caracterize uma dilação do processo inexistente na via individual, não impedirá a coletivização. 
Se o réu pudesse escolher o tipo de processo ao qual seria submetido, muitas das características dos institutos fundamentais do processo seriam deturpadas, como a inevitabilidade da jurisdição ${ }^{45}$ e o direito de agir contra o réu ${ }^{46}$.

Nada obstante, o oferecimento do contraditório antes de se tomar a decisão de se coletivizar uma demanda é um dever do juiz, para aproximar sua atividade dos anseios constitucionais que visam a garantir justiça procedimental à base da participação e da razoabilidade ${ }^{47}$.

Sobre o momento em que a decisão deverá ser tomada, parece natural que o momento mais adequado seria o despacho liminar, que aceita a petição inicial e determina a citação.

Nesse caso, antes de se determinar a citação do réu para contestar, deveria ser determinada sua citação e a intimação do autor, para se manifestarem quanto à possível coletivização da demanda, em função dos fatos narrados e dos elementos dos autos indicarem que o caso envolve um direito indivisível ou individual homogêneo, que abrange um número significativo de pessoas, que não poderiam ser litisconsortes necessários ou que ajuizariam centenas, ou milhares de ações muito parecidas, de maneira desnecessária e nociva para a atividade jurisdicional.

Nessa decisão liminar, deverá o juiz explicitar porque o direito parece indivisível ou individual homogêneo (indicando a circunstância de fato, relação jurídica ou origem comum que constitui a classe), bem como porque lhe parece inviável o litisconsórcio necessário, além de já definir a classe, o pedido a ser coletivizado e a sua causa de pedir.

Percebe-se assim, que a decisão prévia, que abre ao contraditório das partes antes que se converta uma ação individual em coletiva, deve conter basicamente os mesmos pontos obrigatórios da decisão que coletiviza a demanda individual, entretanto, no primeiro caso o juiz deverá ser mais sucinto.

\footnotetext{
${ }^{45}$ Antonio Carlos de Araújo CINTRA; Candido Rangel DINAMARCO; Ada Pellegrini GRINOVER. Teoria Geral do Processo, p. 137-138.

${ }^{46}$ Piero CALAMANDREI. Instituciones de derechoprocesal civil,p. 241-256; Eduardo J. COUTURE.Fundamentos delderechoprocesal civil,p. 63-78; Francesco CARNELUTTI. Institucionesdel processo civil, p. 316.

${ }^{47}$ Luigi Paolo COMOGLIO. Etica e tecnicadel "giusto processo”,p. 48-49.
} 
Oferecida às manifestações das partes, terá o juiz de tomar uma decisão sobre a questão, intimando as partes de tudo para que recorram, se ficarem insatisfeitas, e deem prosseguimento ao feito, oferecendo contestação.

Ciente da decisão que coletiviza ou não, o réu oferecerá contestação sabendo qual repercussão aquela relação processual poderá ter na sua esfera jurídica.

Nada obstante, parece que o fato do exame da coletivização não ter acontecido quando do despacho liminar, não impedirá que ele aconteça mais a frente, respeitado também um momento limite, a partir do qual a conversão fatalmente prejudicará a tramitação da demanda individual, a não ser que o autor não apresente qualquer oposição, ou que não haja mais provas a serem produzidas, nem com a coletivização, ou ainda, que seja possível a antecipação de tutela, pois presentes os requisitos,sem desaguar em relevante comprometimento do tempo,a ponto de prejudicar de modo irreversível o direito ao julgamento definitivo em tempo razoável.

No direito norte-americano, a conversão em questão pode se dar até que se tenha a decisão final da causa, podendo o juiz alterá-la ou emendá-la durante esse tempo ${ }^{48}$.

Contudo, parece-nos que essa margem de tempo pode prejudicar a celeridade do processo e, portanto, o acesso individual da parte, já que é fundamental que a contestação e a instrução do processo se deem sob o conhecimento de todos, de que o processo em concreto se trata de uma lide coletiva.

Se a decisão que abre a oportunidade de contraditório sobre a coletivização só for proferida após a contestação, mas anteriormente a instrução do processo, ou seja, na fase de saneamento, não se vê como algo prejudicial ao tempo de duração do processo, que se outorgue uma oportunidade de emenda da contestação, se o réu quiser, inaugurando-se posteriormente a instrução do feito.

Todavia, iniciada a instrução sem que tenha sido aberto o debate sobre a necessidade de coletivização, aí nos parece que a causa deverá ser terminada como começou, já que a instrução é das fases mais complexas e demoradas, com a prática de muitos atos, às vezes ao longo de um vasto tempo (como nos casos que envolvem prova pericial), de modo que a repetição de tudo sob a direção de um modelo coletivo atrasará o julgamento do feito.

\footnotetext{
${ }^{48}$ Joshua B. GRAY; Michelle H. SEAGULL."Class Action Reaction: Amended Rule 23 Enhances Judicial Supervision in Class Litigation.”Antitrust, p. 92-93.
} 
Ainda assim, se o autor concordar com a coletivização, ou se possível a antecipação da tutela, pois presentes os requisitos e por não ser relevante a demora, parece-nos possível a conversão, no mesmo sentido que dissemos anteriormente, independentemente da posição do réu, que, a priori, não será diretamente prejudicado pela dilação, muito pelo contrário, já que a não coletivização permitiria que ainda mais ações fossem ajuizadas, inclusive pela via coletiva.

Deve-se considerar ainda, a hipótese em que a questão controvertida seja meramente jurídica ou já tenha sido objeto de prova, de modo que a coletivização não importe em nova dilação probatória; nesses casos, excepcionalmente, a coletivizaçãotambém poderia ocorrer mesmo após a fase instrutória.

Percebe-se assim, que a decisão que coletiviza uma demanda deve ser dividida em dois momentos, quais sejam:pré e pós-contraditório, sendo o primeiro mais resumido, a fim de que as partes tenham conhecimento das perspectivas que permeiam o raciocínio judicial, podendo participar com mais plenitude, e o segundo mais agudo, para definir a questão em primeira instância, abrindo-se à via recursal.

A possibilidade de mudança da decisão ficará adstrita aos casos em que isto não represente acréscimo desarrazoado de tempo, entendida como razoável qualquer modificação até o saneamento do processo, ou represente um acréscimo irrelevante, que poderia, ainda, ter seus efeitos reduzidos com o uso de técnicas antecipatórias, ficando, em caso contrário, condicionada à aquiescência do autor, qualquer modificação ou emenda.

Conclui-se ao final, que esse exame, sobre o possível prejuízo à razoável duração, deverá ser realizado pelo juiz, de maneira casuística, em decorrência da impossibilidade de criação de formulas abstratas e genéricas que abranjam todas as hipóteses, sendo possível, no máximo, o estabelecimento legal de um rol exemplificativo.

Nesse exame, o juiz deverá levar em conta se efetivamente ocorrerá alguma dilação e, se ocorrer, qual a sua provável extensão, bem como a possibilidade da minoração dos seus efeitos pelo uso de medidas liminares.

\subsection{A (des)necessidade de emenda da inicial}

Questão interessante que se coloca para análise, principalmente em vista do projeto do novo CPC, já aprovado pela Câmara dos Deputados Federais, com previsão de técnica 
de coletivização de demanda individual ${ }^{49}$, concerne à necessidade de emenda ou aditamento da inicial da demanda individual, para adequação de sua causa de pedir e pedidos ao novo formato coletivo do processo.

Na forma prevista em lei a emenda ou o aditamento se justificam, pois há um requerimento de coletivização, que se for deferido, atribui ao requerente à obrigação de aditar ou emendar a inicial, entretanto, na hipótese vertida no presente trabalho, em que a coletivização ocorre de ofício, parece-nos que a emenda ou o aditamento obrigatório constituem atos que, além de desnecessários, poderiam obstar o alcance da finalidade pretendida com a técnica em questão.

$\mathrm{O}$ receio se justifica porque, uma vez identificado um direito coletivo, seja ele indivisível, seja ele individual homogêneo, se presentes os demais requisitos, tal como a numerosidade do grupo de afetados, o Judiciário realizará a coletivização, para que sua atuação tenha seus efeitos espraiados sobre todas as relações jurídicas correspondentes àquele direito coletivo, contudo, se para tanto ele depender de que o autor ou qualquer outra pessoa emende ou adite a inicial, seria fácil burlar a ocorrência da coletivização, bastando o descumprimento da decisão para tanto.

Desse modo, ficaria a critério do autor ou de outras partes a efetivação da coletivização, o que conflitaria com o espirito publicista da jurisdição e dos objetivos de celeridade e segurança visados com a ampliação do uso do processo coletivo.

Ainda que aplicássemos por analogia o dispositivo do CPP, que autoriza ao juiz, o encaminhamento do processo para o Procurador Geral de Justiça em caso de não oferecimento da denúncia, ou, na nossa hipótese, em caso de não emenda da inicial, isso geraria um atraso ao processo e mais, poderia desaguar num conflito institucional, caso o M.P. entendesse ao final pela não emenda e nenhuma outra parte a realizasse.

Uma coisa é o M.P. não querer se manifestar, por achar que não existe interesse social; nesse caso não haverá nulidade, pois há entendimento majoritário no sentido de que basta a intimação do M.P. para que se satisfaça a norma que impõe sua participação, ${ }^{50}$ podendo o responsável sofrer as consequências administrativas de eventual desídia no desempenho de sua função; outra coisa é o M.P., ou qualquer outra pessoa legitimada, não

\footnotetext{
${ }^{49}$ Disponível em: http://legis.senado.leg.br/mateweb/arquivos/mate-pdf/151972.pdf, p. 170.

${ }^{50}$ Hugo Nigro MAZZILLI. "O ministério publico e a jurisdição voluntária.” Disponível em: http://www.mazzilli.com.br/pages/artigos/mpjurvol.pdf, p. 18.
} 
querer oferecer emenda, caso em que a coletivização ficaria prejudicada e o Judiciário ficaria sem meios para promover uma atuação mais eficiente.

Sendo assim, entendemos que, se os fins da coletivização se justificam pela maior celeridade e segurança jurídica que se obterá com ela, não se pode deixá-la por conta de outros atores que não o próprio Judiciário, pois a este incumbe adotar oficiosamente, providências que permitam o alcance dos seus objetivos com mais eficiência.

Não se pode deixar o alcance dos fins jurisdicionais ao alvedrio das partes ou de outros entes que não o próprio Judiciário, sob pena de se criar obstáculos ilegítimos a uma efetiva atuação jurisdicional, num cenário privatista que não se coaduna com o pensamento instrumentalista.

Além disso, nos parece que a providência de emenda é desnecessária, pois a sua ausência não inviabiliza o contraditório, nem macula a imparcialidade do juiz.

Parece-nos plenamente possível que a própria decisão adeque a causa de pedir e o pedido, definindo a sua amplitude e o grupo que será afetado, mesmo porque utilizará, para tanto, a petição inicial, que, de maneira implícita e juntamente com as máximas de experiência, lhe dará os subsídios suficientes para identificar a existência de um direito coletivo lato sensu, relativo a uma coletividade, transparecendo ser simples formalidade a exigência de uma petição de emenda.

Pensemos num caso em que um consumidor reivindica a declaração de nulidade de cláusula contratual de adesão, com a devolução das quantias pagas indevidamente em decorrência dela; tendo o juiz conhecimento de que aquele tipo de contrato écomum na sociedade e preenchidos os demais requisitos, poderá ele coletivizar a demanda, para que o julgamento da questão beneficie todos os consumidores na mesma situação.

Para fundar a sua inicial, o autor alegou seus fatos individuais e fez seus pedidos individuais de declaração de nulidade e repetição do indébito; agora pense na hipótese em que ele tenha de aditar a causa de pedir e o pedido, pelo fato do Judiciário ter entendido que se trata de direito individual homogêneo, o que seria emendado à inicial?

$\mathrm{O}$ autor teria que alegar que inúmeras outras pessoas se encontram em situação similar, tendo formulado o mesmo tipo de contrato, requerendo ao final a declaração de nulidade para todos e a condenação genérica a devolução a todos os consumidores das quantias indevidamente recebidas; nesse diapasão pergunta-se, haveria alguma mudança substancial no litigio, que a própria decisão de coletivização já não teria proporcionado? 
Pensamos que não e tomamos como base, para tal afirmação, a própria desnecessidade de emenda da inicial quando ocorre o incidente de resolução de demandas repetitivas, o que é uma técnica diferente, conforme se verá no capítulo 5, mas que também trabalha com a ideia de objetivação da atuação jurisdicional, sem que haja emenda da causa de pedir ou do pedido.

No caso do incidente ocorre a difusão do julgado sobre todos os processos envolvendo a mesma questão, sem que para tanto tenha haver pedido da parte neste sentido, de modo que podemos questionar, porque isso seria possível num caso e não no outro? A mesma situação ocorre nos casos de recursos repetitivos.

Pensemos agora num exemplo envolvendo direito indivisível, lastreado na pretensão de instalação de filtro antipoluente em chaminé de uma fabrica; na causa de pedir alega-se os danos individuais que vem sendo suportados e no pedido requer-se a condenação a obrigação de fazer.

Constatado que o objeto da ação incide sobre relação jurídica indivisível, consubstanciada no direto ao meio ambiente protegido, como a emenda, para dizer que aquela poluição prejudica toda a comunidade, poderia ser relevante, se tal característica já tiver sido percebida pelo juiz?

Em verdade, a possibilidade de tal prejuízo já estará registrada na decisão que coletiviza e que será precedida do contraditório, não havendo necessidade de emenda, pois o Judiciário já terá aferido que, se os fatos se confirmarem, toda a comunidade estará sendo prejudicada e não apenas o autor da ação, pela própria natureza do objeto da demanda (incindibilidade), sendo desnecessária a emenda do pedido, pois recaindo ele sobre relação indivisível, já terá o condão de afetar a todos que dela participem.

Conclui-se então, que não será a emenda que favorecerá o contraditório entre as partes, pois este já será satisfeito previamente à coletivização, com a oportunidade de manifestação, e posteriormente, com o conhecimento da decisão, que explicitará qual tipo de direito coletivo lato sensu está em jogo e qual grupo será afetado pela decisão,possibilitando uma eventual reação.

Do mesmo modo, não haverá incremento a imparcialidade do juiz, pois quando ele decide por coletivizar, não afirma existir um direito coletivo sendo violado, mas sim a possibilidade de tal situação, caso se comprove legítima e verdadeira a pretensão autoral. 


\subsection{A competência para a conversão e o julgamento da demanda individual coletivizada}

Situação de extrema relevância para a técnica proposta neste trabalho concerne à competência do órgão jurisdicional para realizar a conversão de uma ação individual em coletiva e, naturalmente, qualquer resposta a este respeito deve passar pelas regras de competência próprias do processo coletivo, previstas de modo complementar tanto na LACP como no Código de Defesa do Consumidor ${ }^{51}$.

No primeiro diploma o legislador estabelece como foro competente o local do dano, presumindo que toda demanda vise à reparação de dano, o que não é verdade, cabendo ao intérprete assimilar a palavra dano numa dimensão mais abrangente, que envolva também a ideia de risco de dano ou ilícito, como consta do Projeto de Lei 5.139/2009, que propõe uma reformulaçãoda Lei de Ação Civil Pública ${ }^{52}$.

Desse modo, na ação que tenha por objeto apenas a nulidade de cláusulas contratuais, o foro competente será o do local aonde o contrato deva ser cumprido, pois será lá que se terá consumado ou se consumará o dano ou ilícito em desfavor da vítima, em decorrência da incidência das cláusulas contratuais nulas, não se fazendo aplicável a regra que estabelece o domicilio do consumidor, tendo em vista a especificidade da norma sobre a competência em processos coletivos ${ }^{53}$ e a inutilidade na aplicação de regras voltadas para demandas individuais.

Num processo coletivo, naturalmente, muitos representados estarão domiciliados em outras comarcas, sendo impossível a sua fragmentação para atender aos anseios da norma consumerista, de facilitar o acesso para os consumidores; em contrapartida, a tutela coletiva facilita o acesso à justiça de outra forma, dispensado o comparecimento direto do representado em juízo, justificando-se assim como um instrumento legítimo.

\footnotetext{
${ }^{51}$ Rodolfo de Camargo MANCUSO. Ação Civil Pública.p. 99-100. No mesmo sentido: Aluisio Gonçalves de Castro MENDES. Ações coletivas no direito comparado e nacional, p. 239.

${ }^{52}$ Athos Gusmão CARNEIRO. "Da 'competência' no projeto de lei de nova ação civil pública". In: Petronio CALMON; Mirna CIANCI; et al (Coord.).Em defesa de um novo sistema de processos coletivos: estudo em homenagem a Ada Pellegrini Grinover,p. 82. No mesmo sentido: MENDES, op. cit. p. 246, nota 51. Segundo o autor: "Em primeiro lugar, cabe ressaltar que a regra estabelecida leva em consideração não apenas o dano, mas, sim, a possibilidade de se ter concretizado ou de estar na iminência de ocorrer apenas o ato ilícito, tendo em vista o cabimento da tutela inibitória coletiva ou mesmo de demandas meramente declaratórias ou constitutivas de caráter coletivo."

${ }^{53}$ Ibid., p. 86-87.
} 
Ao disciplinar a competência para o processo coletivo no CDC, o legislador complementou a norma já existente sobre o tema ${ }^{54}$, disciplinando que a abrangência ou extensão da repercussão dos fatos objetos da demanda definirão se a demanda pode ser processada em qualquer comarca concorrentemente competente, ou se apenas as comarcas das capitais e do Distrito Federal terão competência, ressalvando a competência da Justiça Federal, para as hipóteses envolvendo interesse da União, o que foi objeto de divergência durante algum tempo, pacificada por decisão do STF, que preservou a competência da Justiça Federal também para as hipóteses em que o local do dano não tenha vara federal ${ }^{55}$.

Idêntica ressalva cabe também para as hipóteses de ações coletivas envolvendo relação de trabalho ${ }^{56}$.

Deve-se registrar, que qualquer violação às regras de competência no âmbito coletivo representa nulidade absoluta, já que considerada de natureza funcional, como a lei deixa transparecer, por inspiração nas lições de GIUSEPE CHIOVENDA, que especificava a competência territorial lastreada na proximidade do juiz com o objeto da demanda, como um competência territorial funcional, pois inspirada na facilidade que a proximidade do juiz com os fatos da causa proporcionaria ao seu julgamento ${ }^{57}$.

Não obstante, parece nítido o interesse público subjacente à natureza territorial envolvendo direitos coletivos lato sensu, como ocorre em outras hipóteses em que o critério territorial também é tido como absoluto, como nos casos envolvendo direitos reais ou possessórios sobre imóveis ${ }^{58}$.

Desse modo, coletivizada uma ação individual por um juiz incompetente, estará caracterizado um vício processual de natureza absoluta, conhecível de oficio por qualquer

\footnotetext{
${ }^{54}$ MANCUSO, op. cit. p. 99-100, nota 52; MENDES, op. cit. p. 239, nota 51.

${ }^{55}$ Guilherme José Braz de OLIVEIRA; Samantha Lopes ÁLVARES. In: Suzana Henriques da COSTA (Coord.). Comentários à Lei de Ação Civil Pública e Lei de Ação Popular, p. 341. No mesmo rumo: MENDES, op. cit. p. 239-243, nota 51.

${ }^{56}$ Ibid., p. 342-343 (Comentários à Lei ...); MENDES, op. cit. p. 239, nota 51. No mesmo sentido: Elton VENTURI. "A competência jurisdicional na tutela coletiva.”In:Ada Pellegrini GRINOVER;Aluisio Gonçalves de Castro MENDES;Kazuo WATANABE (Coord.). Direito processual coletivo e o anteprojeto de Código Brasileiro de Processos Coletivos, p. 97-98.

${ }^{57}$ Ibid., p. 336-337 (Comentários à Lei ...).

${ }^{58}$ Fredie DIDIER JÚNIO; Hermes ZANETI JÚNIOR. Curso de Direito Processual Civil.p. 134. Para os autores, a Lei de ação civil publica não estabelece um critério territorial funcional de competência, mas sim um critério territorial absoluto, como já existe no CPC e em outras legislações federais.
} 
instância e alegável em qualquer momento, ressalvadas as restrições típicas dos recursos excepcionais, ligadas principalmente à necessidade de prequestionamento ${ }^{59}$.

Reconhecida a incompetência absoluta, restará nula a decisão que coletivizou a demanda, retornando o processo ao modelo individual de resolução de conflitos.

Percebe-se assim, que o juiz só poderá coletivizar a demanda, quando a sua competência em concreto para a demanda individual, coincidir com a competência para uma demanda similar, mas de proporções coletivas; caso contrário, a decisão que converter uma demanda individual em coletiva será nula.

Assim por exemplo, numa demanda individual ajuizada por consumidor em seu domicilio, situado em foro diferente daquele onde tenha ocorrido o dano, o juiz não poderá coletivizar a demanda, pois ele não terá competência para o julgamento de uma demanda coletiva.

Contudo, se o foro do domicilio do consumidor for o mesmo do local da ocorrência ou do risco de dano, ou ilícito, a coletivização não encontrará óbice decorrente da incompetência absoluta, a não ser que a extensão do dano assim indique.

Da mesma forma, numa demanda envolvendo a tutela do meio ambiente, se o autor residir num dos locais afetados, mas não na capital, e a repercussão dos danosfor regional, atingindo a capital, o juiz da comarca onde está domiciliado o autor não terá competência para coletivizar essa demanda; somente o juiz da capital poderá realizar tal coletivização, mediante ações individuais que lá tramitem.

Quanto à nulidade da decisão adotada por juiz incompetente, algumas ponderações deverão ser feitas, com base na instrumentalidade das formas, dentro das limitações que a aplicação dessa teoria encontra quando o assunto envolve uma norma de interesse público, como a competência ${ }^{60}$.

Nesse sentido, parece-nos razoável que, se o juiz prolator da sentença coletiva, sendo incompetente para tanto, for competente para o julgamento da demanda na via individual, a decisão de coletivização será nula, mas o mérito da sentença poderá ser aproveitado, para que a questão se mantenha decidida na via individual, sem que o autor

\footnotetext{
${ }^{59}$ BRASIL: AgRg no AREsp 264681 / MS, agravo regimental no agravo em recurso especial 2012/02539073, Min. Arnaldo Esteves Lima, T1 - Primeira Turma, data do julgamento: 17-10-2013, data da publicação: DJe 30-10-2013, disponível em: www.stj.jus.br, consultado em: 25-12-2013.

${ }^{60}$ José Roberto dos Santos BEDAQUE. Efetividade do processo e técnica processual, p. 193.
} 
padeça com o atraso inerente ao reenvio do processo à primeira instância para novo julgamento.

Para realizar tal asserção, devemos analisar se haveria algum prejuízo para as partes ou para algum interesse público, com a adoção de tal providência, já que a teoria da instrumentalidade das formas somente pressupõe a ausência de nulidade se não houver prejuízo com a informalidade ${ }^{61}$.

Dessa maneira, pode-se dizer que para o autor não haverá prejuízo, pois o juiz, apesar de incompetente para o julgamento de uma ação coletiva envolvendo aquele tema, era o competente para o julgamento de uma ação individual que envolvesse o mesmo objeto, de modo que não haveria sentido em se anular uma decisão e obrigar o mesmo juiz a proferir nova decisão sobre as mesmas questões de mérito, já julgadas anteriormente.

O mesmo raciocínio se estende ao réu e ao interesse público subjacente às regras de competência, pois não teria como se alegar prejuízo algum, para obrigar que o processo retornasse ao mesmo juiz para julgamento da mesma matéria já julgada no mesmo processo.

A nulidade estaria, portanto, apenas na decisão que coletivizou a demanda individual, pois tomada por um juiz que não tinha competência para julgar uma demanda coletiva, o que, por conseguinte, contamina toda eficácia coletiva esperada dessa ação, contudo, sem prejudicar os aspectos individuais do processo, que permaneceram presentes.

Ainda que alguma parte alegasse que sua defesa ou estratégia seria diferente se soubesse que o processo seria conduzido e julgado pela via individual, tentando assim anular todo o processo, fato é que numa demanda coletiva se tem a mesma, ou até maior, amplitude para se realizar atos de defesa e prova, mesmo porque, os efeitos que serão produzidos por esse processo são infinitamente maiores e mais importantes, e consequentemente, o empenho das partes costuma ser maior, por temerem a maior gravidade de um resultado negativo.

Sendo assim, para a parte obter êxito com tal argumentação, terá que demonstrar no caso em concreto qual ato de defesa do seu direito foi suprimido em seu desfavor, prejudicando a sua atuação, para que não se anule desnecessariamente sentenças aproveitáveis.

\footnotetext{
${ }^{61}$ Candido Rangel DINAMARCO. A instrumentalidade do processo, p. 381. A instrumentalidade das formas se identifica com o que o autor denominou de aspecto negativo da instrumentalidade.
} 
Em verdade, a sentença coletiva nula por ter sido proferida por juiz incompetente, mas que seria competente para julgar o caso trazido originariamente pela via individual, poderá ser aproveitada como uma sentença individual.

Num caso envolvendo, por exemplo, danos decorrentes do uso de um produto, ou a nulidade de cláusulas contratuais e ressarcimento por quantias pagas a mais, ainda que a parte genérica da sentença, que se estende às partes representadas, seja nula, pela incompetência absoluta, se o juiz era o competente para julgar individualmente a lide, o capítulo individual da sentença ${ }^{62}$ deverá ser aproveitado.

Parte-se da premissa que, apesar de coletivizada a demanda individual, o juiz não deverá ignorar os contornos individuais envolvendo a parte autora quando sentenciar, estabelecendo um capítulo para dizer sobre a lide individual, capaz de ser julgada por inteiro, já que originou o processo coletivo, e outro, para os direitos individuais relacionados.

Se a demanda individual envolver direitos indivisíveis ligados, por exemplo, ao meio ambiente e à necessidade de interrupção da atividade de uma indústria, aí sim poderá não haver capitulo individual, todavia, se o juiz prolator da sentença coletiva nula tiver competência para julgar a questão no modelo individual de processo, a sentença poderá ser aproveitada apenas para o individuo, já que não será possível constatar prejuízo em seu desfavor, ou em desfavor de qualquer outra parte ou interessado, pois, insista-se, se anulada a sentença e remetido os autos para a instância a quo, a lide seria novamente julgada pelo mesmo órgão.

Caso o juiz prolator da decisão coletiva não tenha competência nem para o julgamento da demanda na via individual, aí sim a sentença será anulada, juntamente com a decisão de coletivização, sendo remetido o processo ao juiz competente para o julgamento da ação originariamente individual.

O novo juiz, agora definido como competente pelo Tribunal, apenas poderá coletivizar a demanda individual novamente se ele reunir também a competência para o julgamento do processo coletivo e mais, se a parte autora, após intimada, não apresentar

\footnotetext{
${ }^{62}$ Candido Rangel DINAMARCO. Capítulos de sentença, p. 35. Segundo o autor: "Definem-se portanto os capítulos da sentença, diante do direito positivo brasileiro e dessas considerações, como unidades autônomas do decisório da sentença. É no isolamento dos diversos segmentos do decisório que residem critérios aptos a orientar diretamente a solução dos diversos problemas já arrolados, quer no tocante aos recursos, que em todas as demais áreas relevantes, já indicadas."
} 
nenhuma objeção razoável à coletivização, como por exemplo, a necessidade de produção ou repetição de alguma prova, pois do contrário, ela terá direito a um julgamento em tempo razoável $^{63}$, que seriaameaçado pela coletivização no caso em concreto.

Por fim, cabe-nos apenas manifestar nossa posição sobre a definição da competência territorial funcional nos casos envolvendo direitos coletivos lato sensu, já que existe grave dúvida sobre o significado dos termos local, regional e nacional ${ }^{64}$, usados no diploma consumerista para definir os foros concorrentemente competentes, com base na extensão dos danos ou riscos criados pelos fatos narrados na inicial.

Nessa seara, importante contribuição argumentativa nos fornece o projeto da novaLei de Ação Civil Pública, que estabelece os foros das capitais e do Distrito Federal como competentes concorrentemente entre si, com exclusão dos demais, apenas nos casos em que eles tenham sido atingidos pelos fatos narradosna inicial ${ }^{65}$.

Se o dano tiver repercussão regional, mas não envolver nenhuma capital, os foros competentes serão apenas os das comarcas afetadas; de igual modo, se os danos tiverem repercussão nacional, mas não envolverem o distrito federal, apenas as capitais envolvidas serão concorrentemente competentes ${ }^{66}$.

Percebe-se assim, que o projeto de lei dá verdadeiro sentido ao conceito funcional que se embutiu na competência territorial coletiva, pois se aquele pressupõe a proximidade do juiz com o dano para que ele julgue melhor, como nos faz crer o artigo $2^{\circ}$ da LACP, de nada adiantaria estabelecer como competente a capital do estado ou do país, se nesses locais não tiverem sido sentidos os impactos dos danos ou seus riscos.

Pode-se concluir, então, que a proposta interpretativa ora encerrada mostra-se mais racional, na medida em que se coaduna com uma visão sistemática e teleológica das

\footnotetext{
${ }^{63}$ José Rogério Cruz e TUCCI. "Garantia da prestação jurisdicional sem dilações indevidas como corolário do devido processo legal." Revista de Processo, p. 74-75. Alessandro PIZZORUSSO. “Garanziacostituzionaledell'azione.”Digesto delle Discipline Privatistiche - SezioneCivile, p. 613.

64 Sobre a dificuldade de se compreender objetivamente os termos local, regional ou nacional: Aluisio Gonçalves de Castro MENDES. Ações coletivas no direito comparado e nacional.p. 246. Ver também: Elton VENTURI. A competência jurisdicional na tutela coletiva. In:Ada Pellegrini GRINOVER;Aluisio Gonçalves de Castro MENDES; KazuoWATANABE (Coord.). Direito processual coletivo e o anteprojeto de Código Brasileiro de Processos Coletivos.p. 99.

${ }^{65}$ Athos Gusmão CARNEIRO. "Da 'competência' no projeto de lei de nova ação civil pública”. In: Petronio CALMON; Mirna CIANCI; et al (Coord.).Em defesa de um novo sistema de processos coletivos: estudo em homenagem a Ada Pellegrini Grinover, p. 79 e 82-83. No mesmo sentido: MENDES, op. cit. p. 247, nota 64.

${ }^{66}$ MENDES, op. cit. p. 247, nota 64. Segundo o autor: "Pela nova proposição, contudo, a Capital do Estado somente será competente se estiver sendo atingida, regra que valerá também para o Distrito Federal, sendo que, neste caso, a competência será concorrente com a das demais Capitais envolvidas."
} 
normas sobre competência no processo coletivo, além de se coadunar com as lições clássicas sobre competência territorial funcional.

Importante ressaltar, que apesar do CDC falar em competência das capitais ou distrito federal para os casos de abrangência regional ou nacional, a LACP fala no local do dano como foro competente de maneira absoluta, motivo pelo qual, pela conjunção das duas normas numa via de compatibilidade, encontra-se resultado similar à proposta interpretativa ora realizada, o que torna flagrante a sua convergência com o microssistema coletivo e os seus propósitos.

Outrossim, qualquer interpretação tendente a reduzir ao distrito federal a competência para julgar demandas envolvendo danos ou riscos de âmbito nacional resta totalmente superada, pois o CDC, ao estabelecer a competência das capitais ou distrito federal, assim o fez num único inciso, pelo uso de partículas alternativas que emprestam o sentido de concorrência ao foros das capitais e do distrito federal, tanto para os casos de danos nacionais como regionais ${ }^{67}$, já estando consolidado o entendimento do STJ neste sentido ${ }^{68}$.

\subsection{Das hipóteses em que não deverá haver coletivização}

Já vimos nos tópicos acima, duas causa que obstariam a coletivização de demandas individuais, versem elas sobre direito indivisível ou individual homogêneo, quais sejam: na hipótese de gerar uma demora significativa a tutela pretendida pela parte, e na hipótese de incompetência do juiz, para o julgamento da demanda coletivizada.

Nada obstante, vimos também, que ao menos a primeira hipótese é passível de uma análise bem casuística, que deverá levar em conta o consentimento da parte autora e o momento da coletivização.

Assim por exemplo, mesmo quando concluída a instrução, se a coletivização não importar na repetição ou realização de novas provas, ou, ainda se importar, mas

\footnotetext{
${ }^{67}$ Ibid., p. 245.

${ }^{68}$ Guilherme José Braz de OLIVEIRA; Samantha Lopes ÁLVARES. In: Suzana Henriques da COSTA (Coord.). Comentários à Lei de Ação Civil Pública e Lei de Ação Popular, p. 338-339.
} 
nãorepresentar um atraso relevante, podendo, em um caso ou em outro ainda ser minorado pelo uso de medidas liminares, não se encontrarão óbice legítimos à coletivização.

Nesse sentido, é certo que, não sendo a demora excessiva, seus efeitos poderão ser minorados pelo uso da tutela antecipada, que, todavia, não substitui o julgamento definitivo e, portanto, não servirá em caso de demora relevante, dependendo ainda da presença dos respectivos requisitos.

Além dessas duas hipóteses, obviamente também não deverá haver coletivização quando constatada a litispendência ou a existência de coisa julgada no plano coletivo, comparadas ai a causa de pedir e os pedidos.

De todo modo, parece-nos razoável que não reduzamos os óbices à coletivização a essas hipóteses, pois a riqueza das possibilidades fáticas sempre tende a nos surpreender ${ }^{69}$, mormente quando da aplicação de normas taxativas.

Nesse sentido, pode ocorrer da coletivização obrigar as partes a produzirem provas que não seriam necessárias na via individual, ampliando em demasia o tempo de duração estimado para o processo, o que seria uma justificativa para a não coletivização, mesmo que essa constatação se desse anteriormente ao inicio da fase instrutória e que fosse possível a antecipação de algum resultado.

Pensamos então, ser muito mais salutar que a análise de outras hipóteses de óbice à coletivização fique a cargo do Judiciário, que, no caso em concreto, examinará se efetivamente haverá algum prejuízo para a parte e à razoável duração do processo, a coletivização de demanda individual, sendo relevante destacar, que tal decisão estará sujeita a todos os cânones relacionados à legitimidade das decisões judiciais, tais como publicidade, motivação, contraditório e recorribilidade.

Conclui-se assim, pela existência de hipóteses claras em que a coletivização ficará obstada, que, todavia, não esgotam todas as possibilidades existentes, podendo haver casos outros em que a coletivização se mostre nociva, por prejudicar a razoável duração do processo, por exemplo, cabendo ao Judiciário a identificação dessas situações no caso em concreto.

\footnotetext{
${ }^{69}$ Cassio ScarpinellaBUENO. Amicuscuriae no processo civil brasileiro: um terceiro enigmático, p. 19.
} 


\subsection{Dos casos em que há cumulação de pedidos individuais heterogêneos}

Nesse cenário, importante questão concerne à possibilidade de coletivização de demanda que contenha, ao lado de pedido relativo a direito indivisível ou individual homogêneo, pedidos relativos a direitos individuais heterogêneos.

Segundo o projeto do novo CPC, em tal hipótese ocorreria a autuação apartada da parte concernente a direito indivisível, que ficaria com a petição de emenda ou aditamento $^{70}$, de modo que, constatado que os pedidos individuais possam ser julgados antecipadamente, pudesse o Judiciário assim proceder, evitando atrasos indevidos.

Deve-se destacar que a técnica de coletivização prevista no novo diploma abrange apenas hipóteses envolvendo direitos indivisíveis, de modo que todo pedido individual seja autuado em apartado, naturalmente, com o fim de poder ser julgado antecipadamente, caso isso seja possível, por se pressupor que as questões individuais sejam mais rápidas para serem julgadas e não poderiam ficar subordinadas ao julgamento da questão coletivizada.

Em outra mão, contudo, temos a técnica do incidente de resolução de demandas repetitivas, que não prevê a necessidade de autuação em apartado das questões individuais, que não tenham relação com a questão cujo julgamento será centralizado na segunda instância.

Mesmo que se argumente que tal técnica não prevê o julgamento de fatos, ainda assim ela pode proporcionar o atraso dos processos individuais, no que tange aos pedidos cumulados que não dependam daqueles que justificaram a instauração do incidente e, desse modo, seria gerado um atraso desnecessário.

Nesse sentido, nos parece interessante à técnica que prevê a autuação em apartado de parte da demanda que se refira a pedidos estritamente individuais, ou seja, que não tenham nexo com uma relação indivisível ou, no nosso caso também, com direitos individuais homogêneos, contudo, consideramo-la desnecessária, pois eventual demora excessiva que venha a ser causada pela coletivização, em verdade, deverá ser fundamento para a não coletivização, uma vez que o direito a razoável duração do processo abrange tanto os direitos individuais, como aqueles indivisíveis e individuais homogêneos.

${ }^{70}$ Disponível em: http://legis.senado.leg.br/mateweb/arquivos/mate-pdf/151972.pdf, p. 171. 
Desse modo, se constatado num caso em concreto, que a coletivização tornará mais complexa a fase instrutória, por exigir provas que antes não seriam exigíveis, o processo não deverá ser coletivizado, a fim de que não se prejudique o direito fundamental à razoável duração do processo, a não ser que se trate de demora pequena, que muitas vezes ainda possa ser amenizada com a tutela antecipada, por exemplo, se presentes os respectivos requisitos.

Nada obstante, se pensarmos bem, tratando-se de direito indivisível, dificilmente o processo se tornará mais complexo somente pela coletivização, pois a provas que seriam produzidas no modelo individual deverão ser as mesmas do modelo coletivo, e a possibilidade de intervenção do M.P. já existe no modelo individual, bem como a possibilidade de intervenção de litisconsortes, na forma da assistência litisconsorcial.

Se o autor quis cumular a pretensão sobre direito indivisível com a ligada a direito individual, foi uma opção que ele fez, sofrendo pouca influencia por conta da coletivização.

Por outro lado, no que tange aos direitos individuais homogêneos, se houver a cumulação de uma pretensão concernente a este tipo de direito, com inúmeros outros direitos individuais heterogêneos, e caso a coletivização torne demasiadamente demorada a instrução, não deverá haver coletivização.

Todavia, também entendemos que aqui, normalmente, não haverá essa complexificação da fase instrutória, mesmo porque a sentença, no que tange a parte dos direitos homogêneos, será genérica, ou seja, prescindirá de elementos individuais que tenham sido obtidos por meio de uma dilação probatória.

Até pode ocorrer, de ter que se ouvir uma ou outra testemunha a mais, ou se fazer uma pericia com mais quesitos ou mais experts envolvidos, mas isso, normalmente, não terá o condão de provocar um atraso significativo, podendo ser ainda mais irrelevante se providências antecipatórias puderem ser adotadas, e, quando tiver, não deverá haver coletivização, porque o individuo tem o direito a razoável duração do processo também no que tange a essa parte do litigio, que se ficar comprometida pela coletivização, comprometerá os direitos individuais do autor da ação, a não ser, insista-se, que a maior dilação do processo seja pequena, podendo, muitas vezes, ser amenizada com o uso da tutela antecipada. 
Nesse senda, podemos trabalhar com o seguinte exemplo: em uma demanda, o proprietário de uma área requer a interrupção de atividade industrial realizada pelo seu vizinho, alegando danos ambientais que vem sendo causados a sua propriedade; na mesma demanda, ele requer a reintegração na posse de parte da área ocupada pela indústria, alegando que esta invadiu uma parte da área que era possuída por ele.

Nessa situação, tem-se um direito indivisível, de proteção ao meio ambiente, cumulado com uma pretensão possessória, estritamente individual, todavia, percebe-se que a coletivização na parte ligada a proteção do meio ambiente, não gerará alteração na fase instrutória, que haveria se o processo prosseguisse individualmente, ou seja, as mesmas provas que seriam produzidas num modelo deverão ser produzidas no outro.

Outrossim, naturalmente o parquet terá que participar dessa demanda, pelo interesse social envolvido, e a possibilidade de assistentes litisconsorciais ingressarem já existe, na mesma medida em que litisconsortes poderiam ingressar numa demanda coletiva.

Não bastasse, ainda que se pudesse falar num atraso gerado pela coletivização, admitiríamos então que a pretensão ligada a direito indivisível sofresse um atraso, por conta de uma coletivização indesejada pelo autor, em flagrante vilipendio a razoável duração?

Parece-nos que o mesmo direito a um julgamento célere para os direitos individuais deverá existir para os direitos indivisíveis, razão pela qual se defende que, constatada a probabilidade de demora excessiva pela coletivização, está não deverá ocorrer.

Agora, se pensarmos numa ação envolvendo o direito individual homogêneo ao reconhecimento de invalidade de determinada cláusula, cumulado com o pedido de exclusão do nome autor dos órgãos de proteção ao crédito, que decorreu do inadimplemento da referida cláusula, teremos uma hipótese de direito individual homogêneo cumulado com direito individual heterogêneo.

Nesse caso, igualmente, parece-nos que a fase probatória não sofrerá alteração, seja no modelo coletivo, seja no modelo individual, a não ser, talvez, a necessidade de prova documental, para demonstrar a existência de outros contratos similares, o que, entretanto, não estenderá a fase instrutória, pela simplicidade na produção de tal prova.

De outro lado, se alguma demora relevante fosse ocorrer, não poderia haver a coletivização, pois o autor da ação tem o direito de obter o julgamento concernente ao 
direito individual homogêneo em tempo razoável, o que seria vilipendiado pela coletivização.

Dessa forma, podemos concluir que o fato de haver pedidos sobre direitos individuais heterogêneos, cumulados com pedidos sobre direitos indivisíveis ou individuais homogêneos, por si só, não impedirá a coletivização e nem obrigará a autuação em apartado da parte individual, pela desnecessidade e inadequação de tal providencia.

Desnecessidade porque a simples coletivização não gerará sempre uma maior demora para a resolução da lide; muito pelo contrário, as vezes ela poderá gerar até resultados mais rápidos, pela concentração de esforços que envolverá, sendo, por vezes, ínfima ou irrelevante a demora gerada, na sistemática processual atual.

Inadequação porque a autuação em apartado não impediria a demora no julgamento da parte coletivizada, sobre a qual o indivíduo também tem o direito a um julgamento em tempo razoável.

Sendo assim, caso constatada a probabilidade de demora, coletivização nenhuma deverá ocorrer, ou, sendo essa demorapequena, deverá ocorrer a coletivização, com a possibilidade de sua mitigação com instrumentos que já conhecemos, como a tutela antecipada, que permitiria a entrega da proteção jurisdicional invocada, antecipadamente, se presentes seus respectivos requisitos, evitando-se danos irreparáveis ou a demora desnecessária, inclusive com a dispensa da caução, se necessário.

Ressalta-se apenas, que se a demora prevista for excessiva, nem mesmo a tutela antecipada será suficiente, pois a parte tem também o direito à resolução definitiva da sua causa em tempo razoável, podendo ser o caso ainda, dela não preencher os requisitos de uma medida liminar.

A autuação em apartado nos aparenta constituir técnica demais para resultados de menos, motivo pelo qual concluímos pela sua desnecessidade e inadequação para os fins pretendidos. 


\subsection{O direito individual de ação frente à técnica de coletivização de demanda individual}

Analisando a presente proposta sob o prisma do demandante individual, que ingressa com uma demanda passível de coletivização, podemos constatar alguns problemas que poderiam advir, tanto de ordem pragmática quanto jurídica, principalmente no campo dos direitos individuais homogêneos.

Isso porque, um processo coletivo, por menos complexidade que ele envolva, como, por exemplo, num caso em que a discussão principal gravite em torno apenas de uma questão jurídica, ainda assim poderá representar para a parte uma pequenadilação, já que, primeiro, haverá a discussão sobre a possibilidade de coletivização e a presença dos respectivos pressupostos, e, depois, vai haver a interferência do Ministério Público, o que representará mais atos a serem praticados, bem como a produção de provas ou recursos que eventualmente a parte não produziria, além da possível intervenção de litisconsortes ou da reunião por conexão com outras demandas.

Outrossim, como ficariam os honorários pagos antecipadamente pela parte ao seu advogado, bem como o direito da parte desistir da ação, transigir ou renunciar sobre o direito, principalmente quando pensarmos que o interesse do réu fazer acordo num processo individual poderá ser diferente do que poderia haver num processo coletivo?

O direito de ação, inicialmente compreendido como um consectário do direito material, posteriormente como o direito a uma sentença de procedência, depois como o direito a uma sentença de mérito, até a concepção atual, como um direito constitucional de provocar a jurisdição e receber dela uma resposta justa e eficaz ${ }^{71}$, nos conduz a uma posição em que o indivíduo se situa no centro, com autonomia para decidir sobre a sua vida e a repercussão dos seus direitos, mas sem o poder de dizer como a atividade jurisdicional, instaurada pela sua provocação, irá se desenvolver.

Por mais que falemos numa dilação procedimental quando da coletivização de demanda individual, essa simples dilação, consistente na participação de mais atores processuais, não será certeza de maior demora, muito pelo contrário, pois com a

\footnotetext{
${ }^{71}$ Piero CALAMANDREI. Instituciones de derechoprocesal civil, p. 241-256; Eduardo J. COUTURE.Fundamentos delderechoprocesal civil,p. 63-78; Francesco CARNELUTTI. Institucionesdel processo civil, p. 316.
} 
centralização das atividades procedimentais e do juízo a ser realizado, existe grande possibilidade de maior agilidade na prestação da tutela, pela maior concentração de atenção e esforços que isso deverá envolver.

Outrossim, técnicas como as medidas liminares permitem a redução dos efeitos deletérios do tempo sobre o direito das partes, apesar de nem sempre poderem ser concedidas e de não substituírem o julgamento definitivo da demandas.

Nessa toada, se a coletivização não representar uma dilação procedimental relevante, efetivamente capaz de gerar grande atraso no processo pela sua excessiva complexificação, o que caracterizaria desrespeito à norma constitucional da razoável duração $^{72}$, não se mostra adequado deixar ao livre alvitre do demandante, optar pela forma como seu conflito será resolvido, se quem resolve o conflito é a atividade jurisdicional.

Além disso,o dever de solidariedade, insculpido no artigo $3^{\circ}$, inciso I da nossa Carta Magna como um objetivo relevante, tem eficácia cogente e incide nesse tipo de situação, para impedir que instrumentos públicos sejam usados com fins egoísticos, como ocorreria se a parte pudesse, por um simples capricho, decidir que o seu processo terá de prosseguir como individual, sem produzir uma decisão com eficácia coletiva.

Como visto, novas pessoas farão parte do procedimento quando este for coletivizado, com novos direitos, deveres, poderes, obrigações e ônus processuais, que alterarão o curso do procedimento, mas sempre de modo a ampliar a proteção do direito inicialmente perseguido apenas pelo individuo.

Ainda que tais pessoas requeiram mais provas e interponham mais recursos, se admitidos pelo juiz, tais atos só terão o condão de beneficiar o individuo, ou seja, a prova requerida pelo Ministério Público, se deferida, será porque se mostrará relevante e capaz de auxiliar no conhecimento dos fatos e, da mesma forma, o recurso interposto por um litisconsorte, se admitido, se justificará pela sucumbência da pretensão coletivizada.

Quanto à questão do acordo, da renúncia ou da desistência, registra-se que o fato da demanda ter sido coletivizada não impedirá o demandante originário de realizar um acordo somente sobre a sua pretensão, a não ser que se trate de direito indivisível, ocorrendo da mesma forma com a renúncia.

\footnotetext{
${ }^{72}$ Jose Rogério Cruz e TUCCI. "Garantia da prestação jurisdicional sem dilações indevidas como corolário do devido processo legal." Revista de Processo, p. 74-75. Alessandro PIZZORUSSO. “Garanziacostituzionaledell'azione.”Digesto delle DisciplinePrivatistiche-SezioneCivile, p. 613.
} 
Se por um lado a coletivização da demanda pode desestimular um acordo individual, por outro lado pode estimular o cumprimento espontâneo do direito, a fim de se evitar demandas individuais que possam ser coletivizadas.

Já a desistência da ação, sempre que esta for requerida pelo demandante originário, poderá o Ministério Público ou qualquer outro legitimado assumir a posição,técnica que a própria Lei de Ação Popular já prevê para essas hipóteses, em seu artigo $9^{\circ}$.

Na hipótese do autor ter pago honorários antecipadamente ao seu advogado, o que é natural que tenha ocorrido, pensamos que isso será irrelevante, pois ele não perderá o trabalho que foi realizado em seu favor; a única diferença é que esse trabalho será aproveitado por toda a coletividade, em favor desta e da própria atividade jurisdicional, que não pode ser obrigada a realização de atividades desnecessária, com processos repetitivos, somente porque uma parte não quer compartilhar os resultados do seus processo com a sociedade.

Mostra-se exacerbadamente egoístico qualquer pensamento que defenda o direito da parte optar pela não coletivização, por ter pago os honorários do seu advogado, primeiro porque o trabalho do seu advogado não será prejudicado, segundo porque isso imporia um custo desnecessário ao Estado e à atividade jurisdicional.

Outrossim, tanto num processo individual como num processo coletivo, o advogado da coletividade fará jus a honorários sucumbenciais, que, aliás, deverão ser mais expressivos num processo coletivo, cabendo a parte que quiser ser ressarcida pelo que pagou antecipadamente, pactuar com o advogado a devolução com base no que for recebido a titulo de sucumbência, tanto na via individual como na via coletiva.

O que não pode é a parte pagar, sem fazer questão de ressarcimento na via individual, e só fazer tal questão se houver a coletivização do feito, mormente porque tal coletivização, insista-se, não prejudica o desempenho no trabalho contratado pelo individuo.

Diante desse cenário, percebe-se que não podemos aqui, advogar um pensamento garantista $^{73}$, que apenas trabalhe a necessidade de proteção das garantias individuais, sob o

\footnotetext{
${ }^{73}$ Sobre o garantismo: Franco CIPRIANI. Nelcentenariodelregolamentodi Klein (Il processo civiletralibertà e autorità). RivistadiDirittoProcessuale, p. 983.
} 
argumento de que o Estado e o juiz devem ter poderes diminutos em face do individuo, para se elidir o risco de se descambar para um autoritarismo ${ }^{74}$.

Muito pelo contrário, já que a presente proposta não restringe nem limita o direito fundamental de ação, mas apenas operacionaliza o alcance da finalidade mirada com a ação de uma maneira diferente, por meio de um processo coletivo, que deverá ser mais célere e seguro.

Se a parte tem o direito fundamental de ingressar com uma demanda e obter uma resposta justa e eficaz, não será a coletivização que prejudicará esse direito, pois o uso de tal técnica deverá oferecer ainda mais eficiência e justiça, evitando julgados conflitantes e a repetição desnecessária de demandas individuais.

Impende registrar, que o presente posicionamento encontra-se em total consonância com atual julgado do STJ, em que se decidiu pela suspensão obrigatória de demandas individuais multitudinárias, conexas a demanda coletiva pendente de julgamento ${ }^{75}$.

Isso porque, se para o STJ não há violação ao direito de ação quando a parte tem o seu processo individual obrigatoriamente suspenso, porque haveria quando a parte tem a sua demanda coletivizada?

Como dito pelo próprio STJ, a sistemática da suspensão obrigatória de feitos já existe no campo dos recursos repetitivos e atende a ideia de instrumentalidade que se espera do processo, por dotá-lo de maior racionalidade quando dispensa a repetição desnecessária de atos e demandas, e elimina o risco de conflitos entre decisões, sendo certo, que na seara dos recursos repetitivos também não pode a parte optar pela suspensão ou não do seu recurso, enquanto se julgam os representativos da controvérsia jurídica.

Perceba que seria inútil defendermos o poder da parte optar pela coletivização ou não, se ela não tiver o direito de optar pela suspensão ou não de sua demanda individual, pois, uma vez afastada por ela a coletivização, ainda assim a sua demanda individual sofreria interferência, dessa vez de maneira até mais contundente, pela suspensão obrigatória imposta por uma instância superior.

\footnotetext{
74 Quanto ao risco de autoritarismo: Franco CIPRIANI. El autoritarismo procesal (y laspruebasdocumentales). Revista IusetPraxis.Talca, versão on-line disponível em: www.scielo.cl/scielo.php?pid=S0718-00122007000200003\&script=sci_ar..., p. 4.

75 BRASIL: REsp 1110549 / RS, Rel. Ministro Sidnei Beneti, Segunda Seção, julgado em 28/10/2009, DJe 14/12/2009. Disponível em: www.stj.jus.br. Acesso em: 02 de julho de 2014. Sobre o julgado ver artigo: Marcelo José Magalhães BONICIO. Análise da tendência jurisprudencial de potencialização dos efeitos da regra prevista no art. 543-C do CPC. Artigo ainda não publicado.
} 
Outrossim, se imaginarmos que a doutrina é firme em defender que processos individuais sejam reunidos aos coletivos por conexão ${ }^{76}$, poderemos concluir que a nossa proposta de coletivização judicial de demandas individuais em nada afeta o direito de ação da parte autora, pois ainda que ela optasse pela não coletivização de sua demanda, poderia ter seu processo individual reunido a um coletivo ao qual ele correspondesse, suportando todos os efeitos procedimentais de tal fenômeno.

A coletivização, repita-se, tem o condão de propiciar mais celeridade, pela concentração e economia geradas, além de mais segurança, pelo fỉm de decisões contraditórias, de modo que não se pode falar que tais resultados representem decréscimo ou prejuízo ao direito de ação; muito pelo contrário, o direito de ação fica incrementado, com técnica nova, capaz de lhe proporcionar maior operacionalidade e eficiência.

Tais observações merecem prosperar também, com ainda mais razão, em se tratando de direitos indivisíveis, pois neste caso, a natureza do direito justifica, quando este envolva muitas pessoas, o tratamento coletivizado, retirando do campo da autonomia da parte o direito de escolher pelo procedimento individual, que se mostrará antiquado para o tipo de direito em discussão.

Nesses casos, naturalmente a coletivização se mostrará necessária, para que se evite um conflito prático entre coisas julgadas ou o desrespeitoao direito de todos os afetados, departiciparem em contraditório de um procedimento que lhes afeta.

Conclui-se assim, que a decisão que obrigatoriamente coletiviza uma demanda individual não se incompatibiliza com o direito fundamental de ação, já que, pelo contrário, dota a jurisdição de mecanismos mais eficientes para o alcance dos seus objetivos e, consequentemente, permite o oferecimento de uma melhor resposta à demanda gerada com base no direito fundamental de ação, o que, aliás, foi defendido como legitima consequência da instrumentalidade processual, quando o STJ decidiu que demandas individuais poderiam ser obrigatoriamente suspensas para esperar processo coletivo, que conferiria maior celeridade e segurança.

\footnotetext{
${ }^{76}$ Ricardo de Barros LEONEL. Manual do Processo Coletivo,p. 256. No mesmo sentido: VENTURI, Elton. Processo civil coletivo: a tutela jurisdicional dos direitos difusos, ..., p. 360.
} 


\subsection{A possibilidade limitada de coletivização de demandas contra a coletividade (ação coletiva passiva)}

No que tange a possibilidade da coletivização ser utilizada em desfavor da coletividade, como nos casos, por exemplo, de ações coletivas passivas, em que uma única pessoa é autora e a coletividade é ré, não vemos problema, desde que ela se restrinja as hipóteses envolvendo direitos indivisíveis.

Essa restrição decorre naturalmente do regime da coisa julgada coletiva, que não pode prejudicar direitos individuais ${ }^{77}$; não podendo prejudicar direitos individuais, não podemos falar na coletivização de uma demanda envolvendo direitos individuais homogêneos, em que a coletividade figure no polo passivo, pela total inutilidade de tal técnica.

Entretanto, em se tratando de uma demanda envolvendo direito indivisível, movida contra um indivíduo que represente uma coletividade, aí sim poderíamos falar na coletivização judicial, pois o regime de coisa julgada secundumeventumprobationis permite a imutabilidade de sentenças contrárias à coletividade, desde que fundada nas provas dos autos ${ }^{78}$.

Aliás, hipótese muito similar a essa situação é aquela em que, por exemplo, uma empresa ingressa com uma ação contra um individuo para obter a declaração de validade de assembleia ordinária realizada em sociedade anônima e, vendo o juiz que aquele indivíduo compartilha o interesse de um sem número de acionistas, coletiviza a demanda para que, ao final, se julgado procedente a demanda da empresa, todo o grupo de acionistas suporte os efeitos da coisa julgada.

Conclui-se assim, que a coletivização passiva seria viável apenas na hipótese de direitos indivisíveis, pois do contrário, o regime da coisa julgada coletiva tornaria inútil tal técnica.

\footnotetext{
${ }^{77}$ Ada Pellegrini GRINOVER; Nelson NERY JÚNIOR; KazuoWATANABE; et al. Código Brasileiro de Defesa do Consumidor: comentado pelos autores do anteprojeto.9.ed. p. 951-954.

${ }^{7878}$ Ada Pellegrini GRINOVER. Ações coletivas para a tutela do ambiente e dos consumidores - a lei 7.347, de 24.7.85. Revista de Processo, p. 117.
} 


\subsection{A coletivização e sua repercussão sobre os processos individuais}

Uma das questões que necessariamente devem ser tratadas quando se idealiza uma técnica de coletivização de demandas individuais, é como ela irá repercutir sobre os processos individuais existentes, porque, se nada acontecer, provavelmente não haverá a interrupção da multiplicação infinita de demandas individuais homogêneas ou contendo bens indivisíveis, o que atrapalhará a consecução dos fins mirados com tal técnica, de proporcionar celeridade e segurança jurídica pela concentração e economia.

Naturalmente, a técnica de coletivização já proporciona economia e celeridade por permitir a centralização do juízo com a eficácia erga omnes ou ultra partes da sentença, entretanto, quando ela não estanca a multiplicação de demandas individuais, ou pelo menos o seu processamento, seus efeitos benéficos tem sua potencia prejudicada, ficando aquém do que poderia.

O mesmo ocorre com a segurança jurídica, que é obtida com a eficácia amplificada da decisão coletiva, mas é prejudicada quando as demandas individuais apresentam resultadosdivergentes, pelo fato de não terem sido suspensas.

Em contrapartida, se a coletivização de uma demanda acarretar a suspensão automática de todas as demandas individuais, numa sistemática similar a do recurso repetitivo $^{79}$, aí nos parece que toda a eficiência proporcionada com a coletivização de uma demanda individual fica potencializada, pois além de se centralizar a atividade de julgar, se centraliza o processamento da questão e se impede a repetição inútil de atos desnecessários, bem como o risco de decisões anteriores em sentido contrário, ou seja, se ganha em celeridade e segurança.

Essa postura já foi defendida, como dito, em recente decisão da lavra do Ministro Sidinei Beneti, que viu na suspensão obrigatória uma ferramenta equivalente a dos recursos repetitivos, que atende aos anseios da instrumentalidade processual $^{80}$, já que, sem suprimir ou prejudicar direito, torna o processo mais dinâmico, menos repetitivo e mais racional.

\footnotetext{
${ }^{79}$ BRASIL: REsp 1110549 / RS, Rel. Min.Sidnei Beneti, Segunda Seção, julgado em 28/10/2009, DJe 14/12/2009. Disponível em: www.stj.jus.br. Acesso em: 02 de julho de 2014. Sobre o julgado ver artigo: Marcelo José Magalhães BONICIO. Análise da tendência jurisprudencial de potencialização dos efeitos da regra prevista no art. 543-C do CPC. Artigo ainda não publicado.

${ }^{80}$ Ibid.
} 
Desse modo, entendemos que a coletivização de uma demanda deverá proporcionar a suspensão automática das ações individuais que não forem reunidas por conexão, mas, entendemos também, que uma vez intimada da decisão que suspende sua demanda individual, a parte tem o direito de requerer que ela prossiga desde que fundamente seu pedido.

Para tanto, deverá apresentar alguma razão que justifique tal requerimento, baseada em alguma particularidade, como, por exemplo, a existência de urgência que não possa ser resolvida apenas pelo uso de medidas liminares, o estágio do processo que já se encontre maduro para sentença, ou na própria ausência de identidade entre as questões objeto de julgamento, o que será aferido pelo juiz de piso, bem como, eventualmente, pelas instâncias recursais, em caso de insatisfação da parte com um indeferimento em primeira instância.

Essa repercussão, da demanda coletivizada sobre as individuais, deverá ocorrer da mesma forma, tenha ela por objeto direito difuso, coletivo stricto sensu ou individual homogêneo, já que em qualquer hipótese o julgado coletivo poderá beneficiar a pretensão individual.

Contudo, se a demanda individual também envolver bem indivisível, como a nulidade de questão de concurso público, a instalação de filtros antipoluentes nas chaminés de uma fábrica ou a anulação de assembleia realizada em sociedade anônima, aí o problema já será de litispendência, devendo haver a reunião dos processos idênticos, quando possível, ou a extinção daqueles que não puderem ser reunidos ao processo coletivo, como exposto no tópico 15.3.

Se as demandas individuais possuírem parcelas que não correspondam à demanda coletivizada, deverão prosseguir apenas no que concerne a essa parte, aguardando para serem sentenciadas conforme o resultado coletivo.

Conclui-se assim, ser ideal um sistema em que a suspensão das demandas individuais seja automática e obrigatória, de modo que o indivíduo,depois de intimado da suspensão, apenas possa reivindicar o prosseguimento individualizado de sua demanda, se apresentar fundamentos para tanto, que serão examinados pelo juízo a quo, podendo, posteriormente, ser objeto de eventual recurso. 


\subsection{A fase instrutória e a sentença que julga a demanda coletivizada}

Coletivizada uma demanda, ela prosseguirá no modelo do processo coletivo, acarretando na suspensão obrigatória das demais demandas individuais que tenham correspondência com ela, ressalvada a existência de alguma urgência ou particularidade que justifique o tramite simultâneo.

Durante a fase de instrução, a parte autora, que teve sua demanda coletivizada ira prosseguir na atuação do seu direito, produzindo as provas que entender pertinentes para os seus direitos individuais, bem como aquelas, que entender úteis à demanda coletiva.

Além da parte, o Ministério Público e eventuais litisconsortes também poderão requerer provas, apenas naquilo que corresponder aos efeitos coletivos que serão obtidos com a demanda, ou seja, aos pedidos que tiverem sido coletivizados.

Aliás, no ensejo se mostra importante registrar a necessidade do juiz se valer dos seus poderes instrutórios, a fim de suprir eventuais omissões cometidas pelos atores mencionados, e determinar de oficio as provas que entender importante para o alcance do julgamento mais justo possível, mormente no que tange a parcela coletiva do julgado.

Concluída a fase instrutória, o processo coletivizado deverá ser sentenciado e, neste momento, surge a necessidade de se perceber que, necessariamente, a sentença se dividirá, pelo menos, em dois capítulos, quais sejam: um sobre a pretensão individual, outro sobre os efeitos coletivos, ressalvada a hipótese de se tratar de direito indivisível e não haver cumulação de pedidos, quando então o pedido julgado será único ${ }^{81}$.

Dessa forma, imaginando uma demanda movida por um consumidor, que questionando a validade de cláusula existente em contrato de adesão, concernente a relação jurídica continuativa, pede a declaração de sua nulidade, com a condenação da empresa ré a devolução das quantias pagas indevidamente por causa dela; se coletivizada essa demanda, por se referir a direitos individuais homogêneos, ao final, a sentença terá necessariamente quatro capítulos, sendo dois para a parte individual e mais dois sobre a parte coletiva.

Nesse panorama, a sentença terá um capitulo para falar do pedido de declaração de nulidade individual, outro para falar do pedido de condenação individual, que deverá ter

\footnotetext{
${ }^{81}$ Candido Rangel DINAMARCO. Capítulos de sentença,p. 35.
} 
sido liquidado durante a instrução, um terceiro para falar da declaração de nulidade para todos os contratos de consumidores em igual situação e, no final, um quarto capitulo para falar da condenação genérica, à devolução de toda quantia recebida dos seus consumidores em virtude de tal cláusula, o que poderá ser apurado em posterior liquidação e execução.

Percebe-se assim, que a coletivização não prejudica de nenhuma forma a pretensão individual, que seguirá em cumulação com os efeitos coletivos, que serão emprestados a atuação jurisdicional por se entender que se trata de um direito individual homogêneo, possivelmente compartilhado por um numero de pessoas que justifique tal coletivização.

Em se tratando de demanda envolvendo direito indivisível, se houver uma única pretensão, que recaia justamente sobre objeto incindível, daí a sentença coletiva será similar a uma sentença proferida numa demanda individual, com efeitos e regime de coisa julgada diferenciados.

Num caso, por exemplo, em que se tenha feito unicamente o pedido de inclusão de medicamento em lista Sistema Único de Saúde, proporcionando às pessoas que o utilizem, o recebimento gratuito ${ }^{82}$, a sentença coletiva que o julgar será similar à sentença de um processo individual, com um leve tempero na causa de pedir, mas analisará um único pedido, concernente a objeto incindível, possuindo um único capítulo.

Mas se imaginarmos que, aliada a essa pretensão, tenha havido a formulação de outra, tangente à condenação da União ao pagamento de danos morais, um pedido relativo a direito individual heterogêneo, nesse caso a sentença deverá ter no mínimo dois capítulos, com um direcionado à análise da pretensão sobre direito difuso, de inclusão do medicamento na lista do Ministério da Saúde - objeto indivisível, e outro à análise da pretensão concernente ao direito individual à indenização, que também, que deverá ser decidido com liquidez.

Nesse contexto, conclui-se que a sentença da demanda coletivizada não ignorará a pretensão individual que deu origem ao litigio, julgando-a sempre juntamente com os efeitos coletivos identificadosno caso, cabendo apenas a sua organização em capítulo diferentes, que correspondam às diferentes pretensões e às diferentes dimensões em que elas serão analisadas, ou seja, na esfera individual e coletiva.

\footnotetext{
${ }^{82}$ Marcelo José Magalhães BONICIO; Heitor Vitor Mendonça SICA. "Ensaio sobre os aspectos materiais e processuais do litisconsórcio unitário."In: Aluisio Gonçalves de Castro MENEDES; Teresa Arruda Alvim WAMBIER. O processo em perspectiva: jornadas brasileiras de direito processual, p. 295.
} 


\subsection{A necessidade de norma que regulamente os requisitos e as consequências da coletivização}

Questão de relevo tangente ao assunto em foco, de coletivização judicial de demandas individuais, refere-se à possibilidade de sua adoção de lege lata ou de lege ferenda, ou seja, com ou sem a elaboração de lei que preveja a utilização prática desta técnica e sua forma de desenvolvimento em juízo.

Apesar de nos parecer extremamente necessária uma modificação imediata no formato atual do modelo estatal de resolução de conflitos que temos, ou seja, do processo, para que ele assuma uma feição coletiva de importância, ao menos equivalente,à feição individual, pensamos também, que a cultura romano-germânica predominante em nosso cenário jurídico impõe que a realização de tal mudança se dê por meio de norma legal, que discipline o uso da técnica de coletivização judicial de demandas individuais.

Somos simpáticos à ideia de sua adoção no atual cenário jurídico, sem a realização de qualquer alteração legislativa, pois acreditamos na força normativa dos princípios e na ausência de óbices legítimos, que pudessem ter sido estabelecidos pela ordem posta, mas temos a consciência de que essa ideia pode não ser compartilhada pela maioria dos operadores do direito, de modo que, devemos concluir pela imprescindibilidade dapromulgação de uma norma legal, que preveja e discipline o uso da técnica em questão,tirando-a do papel e passando-a para realidade, para repercutir positiva e efetivamente na vida das pessoas na sociedade.

Contudo, tal norma encontra-se a caminho, já que o projeto de lei do novo CPC, com as alterações sofridas na Câmara dos Deputados Federais, passou a prever a utilização dessa técnica $^{83}$, razão pela qual, no tópico subsequente, passaremos a analisá-la, elogiando os pontos positivos e criticando os negativos, que infelizmente superam os primeiros.

\footnotetext{
${ }^{83}$ Disponível em: http://legis.senado.leg.br/mateweb/arquivos/mate-pdf/151972.pdf, p. 170.
} 


\subsection{O projeto de lei existente}

O projeto de lei do novo CPC, de $\mathrm{n}^{\circ}$ 8.046, de 2010, elaborado pela Câmara dos Deputados Federais em alteração ao projeto oriundo do Senado Federal, com o $n^{\circ}$ 166, de 2010, prevê, em seu artigo 334, incisos I e II, e dez parágrafos subsequentes ${ }^{84}$, a possibilidade de coletivização de demandas individuais em determinadas hipóteses de direitos indivisíveis, mediante requerimento de um legitimado e ouvido o autor, bem como as hipóteses em que não poderá haver coletivização, além do procedimento que deverá ser observado após a coletivização, com a necessidade de aditamento ou emenda da inicial, de contraditório, a qualidade do autor originário como litisconsorte unitário, a aplicação das regras do processo coletivo, a possibilidade de conversão mesmo diante da cumulação de pedidos individuais e a necessária participação do Ministério Público como custus iuris, quando este não for o responsável pelo requerimento de conversão.

Nesse contexto, podemos principiar a análise da norma em foco, pelo seu caput e parágrafo primeiro, que na contramão do que vem sendo e será falado neste trabalho, condiciona a coletivização ao requerimento de outrem, retirando tal faculdade do juiz, e o que é pior, atribuindo-a apenas aos entes já legitimados pela Lei de Ação Civil Pública ou pelo Código de Defesa do Consumidor.

Percebe-se aí, que por uma tacada só a Câmara sepultou tanto a possibilidade de conversão de ofício, deixando a abrangência da atividade jurisdicional subordinada à vontade de outrem, mesmo nas hipóteses em que isto signifique risco de repetição desnecessária de atos, pela homogeneidade do direito, ou conflito prático entre decisões, pela indivisibilidade do objeto, como a possibilidade de se legitimar o individuo para ser autor de demanda coletiva, ou pelo menos do requerimento de coletivização.

Nesse passo, nota-se que a regra em análise representa pouquíssima mudança, pois, qual a importância de se poder requerer a conversão, se os entes legitimados pela ordem atual já podem entrar com uma ação originariamente coletiva?

Em nossa ótica, só haveria inovação e, consequentemente, chance de melhoria do sistema atual, para expandir o uso da tutela coletiva, se a conversão pudesse se dar de

${ }^{84}$ Ibid., p. $170-171$. 
ofício, após um contraditório prévio, ficando o autor individual incumbido de prosseguir como parte, ao lado de eventuais litisconsortes e da intervenção obrigatória do M.P.

Sem isso, muda-se muito pouca coisa, pois os entes que poderão requerer a conversão já podem ingressar com demandas coletivas com o mesmo objeto, ou seja, eles já podem levar o objeto coletivamente a juízo e não levam, o que nos permite questionar se a simples previsão de pedido de conversão seria suficiente para fazê-los mudar de ideia?

O projeto teria proporcionado algum avanço, se tivesse previsto ao menos a possibilidade do autor individual realizar o pedido de conversão, entretanto, nem isto foi concedido, havendo previsão expressa que limita a legitimidade do requerimento aos entes já previstos em lei como legitimados para iniciar uma ação coletiva.

Outra grande limitação do projeto é não permitir a coletivização quando a pretensão se fundar sobre direitos individuais homogêneos, pois fora argumentado acima, que as demandas repetitivas voltadas à proteção de direito individuais homogêneos são responsáveis, também, pelo profundo congestionamento do Judiciário, que obrigado a praticar atos repetitivos, tanto de instrução como de julgamento, acaba levando muito mais tempo do que deveria, para julgar demandas que poderiam ser eliminadas com muito menos trabalho.

Quando a lei prevê que não poderá haver coletivização, também nas hipóteses em que o processo individual já tenha iniciado a audiência de instrução e julgamento, ou na hipótese de já existir demanda coletiva idêntica ou, ainda, pela falta de competência do órgão para julgar a demanda coletiva, aí ela acerta, trazendo hipóteses racionais que justificam a não coletivização pela presunção de demora, pela litispendência ou pela incompetência absoluta, hipóteses que convergem e contribuem com o que vem sendo falado até então.

No mais, quando estabelecido o procedimento que será observado, se realizada a conversão, poucas observações merecem ser feitas, cabendo-se destacar a disposição concernente à possibilidade de coletivização, mesmo diante da existência de pedidos individuais cumulados, o que geraria o prosseguimento da demanda em autos apartados.

Essa parece ser uma solução atraente, que permitiria uma utilização mais abrangente da técnica, de maneira mais organizada, para que os atos relativos à pretensão coletiva não se confundam ou prejudiquem a execução dos atos relacionados à pretensão 
individual, apesar de lhe considerarmos desnecessária e em certa medida inadequada, como dito acima.

Naturalmente, estar apartado ou não, não será determinante para a eficiência da técnica, sendo fundamental a consciência sobre a existência de capítulos diferentes da demanda, que resultarão em capítulos diferentes na decisão a ser proferida, inclusive com a possibilidade de se adiantar o julgamento sobre os pontos individuais, caso se mostre necessário em vista do mandamento de razoável duração, sem que isso prejudique o uso da tutela coletiva.

No mais, o procedimento estabelecido encontra-se dentro do previsto e esperado, quando fala da possibilidade de aditamento ou emenda, do necessário contraditório subsequente, da participação do autor originário como litisconsorte unitário, da aplicação das normas do processo coletivo e da participação obrigatória do M.P.

Conclui-se assim, que o projeto de lei deixa muito a desejar no que se refere ao objetivo de expansão do uso da tutela coletiva, como meio de se obter mais celeridade e segurança jurídica, principalmente quando condiciona a conversão a requerimento prévio, que deverá ser realizado por ente restritivamente legitimado, sem poder abranger direitos individuais homogêneos.

\subsection{A proximidade entre a técnica de coletivização e as técnicas britânicas para litígios com múltiplas partes (processo por representação e litígios em grupo - GLO)}

Uma técnica alienígena que se aproxima da coletivização judicial de demandas individuais é a prevista na $C P R$ britânica, por meio da qual o tribunal pode transformar um processo individual em coletivo, quando entender que mais de uma pessoa tem o mesmo interesse no julgamento da respectiva demanda (representativerule), ou pode criar um grupo de litígios que possibilite uma gestão unificada, quando eles forem originados por questões de fato ou de direito comuns ou relacionadas ${ }^{85}$.

\footnotetext{
${ }^{85}$ Ada Pellegrini GRINOVER; Linda MULLENIX; Kazuo WATANABE. Os processos coletivos nos países de civil law e common law: uma analise de direito comparado, p. 260-261.
} 
No primeiro caso, por meio de uma decisão judicial, que poderá ser tomada de oficio,para reconhecer a existência de interesses comuns e ordenar que a ação prossiga como coletiva, tem-se um meio eficiente de se promover a administração da justiça, com a possibilidade de se alcançar uma única conclusão para uma controvérsia que afete a milhares de pessoas, como, por exemplo, num caso sobre a devida interpretação de umacláusula contratual, estabelecida por uma empresa de seguro de vida em face de aproximadamente 90.000 (noventa mil) consumidores ${ }^{86}$.

Sem possibilidade de opt out, essa técnica tem sido de pouca utilidade para os ingleses, devido aos restritivos entendimentos jurisprudenciais, que discernem o termo "mesmo interesse" como se se referisse a interesse exatamente idêntico, isto sem falar no alto custo envolvido com tal procedimento ${ }^{87}$.

Por conta da divergência acima, algumas decisões refutam o processo por representação, quando, por exemplo, os valores pleiteados a titulo de indenizações individuais possam ser diferentes, dando ensejo a defesas distintas ${ }^{88}$, contudo, existem manifestações jurisprudenciais que reconhecem a necessidade de flexibilização do termo "mesmo interesse", para que se alcance um maior nível de eficiência ${ }^{89}$, ou seja, se proporcione justiça com um menor gasto de tempo e recursos, num panorama similar ao que ocorre nos E.U.A., quando se fala na necessidade de predominância de questões comuns, para admissão das classactions for damages.

No caso da técnica dos litígios em grupo, destaca-se que também será por meio de uma decisão judicial, que novamente poderá ser tomada de oficio, que se decidirá pela reunião e gestão dos litígios em grupo, quando estes tiverem origem em questões de fato ou de direito comuns ou relacionadas ${ }^{90}$.

Esse mecanismo apresenta uma forma de repartição dos custos do litígio entre todas as partes $^{91}$, que o torna mais acessível e, portanto, mais útil à sociedade em que se encontra inserido como técnica jurisdicional de resolução de conflitos em massa.

\footnotetext{
${ }^{86}$ Neil ANDREWS. O moderno processo civil: formas judiciais e alternativas de resolução de conflitos na Inglaterra.p. 339.

${ }^{87}$ Ibid., p. 340-343. Em sentido similar: GRINOVER; MULLENIX; WATANABE, op. cit. p. 261, nota 85.

${ }^{88}$ Ibid., 340-341.

${ }^{89}$ Ibid., 341-342.

${ }^{90}$ Ibid., p. 345.

${ }^{91}$ Ibid., p. 346-347.
} 
Nessa situação, o modelo de afetação do individuo é oopt in, de modo que caberá a parte requerer a inclusão do seu litígio no cadastro ou registro do grupo, comportandoalgumas variações ${ }^{92}$.

Esse cadastro ou registro será criado pela decisão judicial que estabelece o litígio em grupo, devendo conter as diretrizes que o tribunal entender importantes, as questões comuns ou relacionadas que permitirão identificar outros litígios como pertencentes ao grupo e o órgão que ficará responsável pela gestão desses casos ${ }^{93}$.

Criado o grupo de litígios, as demandas pertencentes a ele irão para o órgão competente, onde permanecerão até nova ordem, cabendo, insista-se, às partes requererem a inclusão de seus litígios nesse grupo, dentro de um prazo que será fixado, conforme informação a ser disseminada pelos meios de comunicação competentes ${ }^{94}$.

Com base no exposto, pode-se concluir que a técnica em foco, de coletivização judicial de demandas individuais, já encontra ao menos em alguma medida, um correspondente no direito estrangeiro, mormente que tange à possibilidade de coletivização de demanda individual de oficio, para envolver também direitos individuais homogêneos, ainda que em contraste com a vontade da parte.

\footnotetext{
${ }^{92}$ Ibid., p. 345. Em sentido similar: GRINOVER; MULLENIX; WATANABE, op. cit. p. 260, nota 85.

${ }^{93}$ GRINOVER; MULLENIX; WATANABE, op. cit. p. 260, nota 85 .

${ }^{94}$ Ibid., 260.
} 


\section{A RELEVÂNCIA DO SISTEMA NORTE AMERICANO DE CLASS ACTIONS PARA A IDEIA DE COLETIVIZAÇÃO DE DEMANDAS INDIVIDUAIS}

Os Estados Unidos da América são hoje o país com o nível mais avançado no uso do processo coletivo, disciplinado pela Rule 23 - Federal Rulesof Civil Procedure (FRCP), fato que é devido mais a fatores culturais do que apenas a condições legislativas.

Em termos legislativos, ou seja, de suficiência das normas existentes para proporcionar bons resultado práticos, deve-se pensar que o Brasil não fica devendo à legislação norte-americana, muito pelo contrário, a técnica prevista no Brasil possui diversas soluções diferentes das apresentadas na regra americana e que, ao menos para a nossa realidade, devem se traduzir em resultados mais apropriados e convenientes.

Nada obstante, em termos práticos, as classactionsestão há anos luz à frente das ações coletivas brasileiras, seja porque são muito mais utilizadas, seja porque o seu uso já apresentou e apresenta resultados efetivamente transformadores da realidade social, o que se pode asserir com base em exemplos como: o caso Brown v BoardofEducation ${ }^{95}$, por meio do qual se combateu a segregação racial na escolas americanas; o caso de reforma estrutural cujo objeto era a melhoria das condições de hospitais públicos para tratamento de doentes mentais ${ }^{96}$ ou; os casos envolvendo danos coletivos pelo uso de agente laranja, asbestos ou implantes de mama ${ }^{97}$, por meio dos quais foram indenizadas milhares de vítimas.

No Brasil, por conta de questões culturais, típicas da cultura jurídica relativa ao civil law, não se tem ainda resultados práticos tão expressivos no âmbito da tutela coletiva, mormente nos campos sociais, ficando os resultados mais importantes ligados as ações por improbidade ou violação aos direitos do consumidor.

\footnotetext{
95“'History of Brown V. Board of Education."Disponível em: http://www.uscourts.gov/educationalresources/get-involved/federal-court-activities/brown-board-education-re-enactment/history.aspx.

${ }^{96}$ Nicholas M. PACE. "Class Actions in the United States of America: an overview of the process and the empirical literature.Disponível em: http://globalclassactions.stanford.edu/sites/default/files/documents/USA_National_Report.pdf. p. 1-99, p. 09.

${ }^{97}$ Ibid., p. 14.
} 
Ademais, é certo também, que a demora para se obter uma decisão sobre o mérito das ações coletivas é outro fator de prejuízo aos resultados esperados, o que também é muito diferente da realidade americana, onde muitas demandas coletivas são objeto de setlementslogo após a sua certificação pela $\operatorname{Corte}^{98}$ e, mesmo quando não há acordo, a demora processual não aparenta ser um problema tão sério, como é para nós.

Nada obstante, pode-se dizer que o estudo da legislação norte americana sobre classactions é importante para a melhor compreensão e utilização do processo coletivo ao redor do mundo, seja pela importância prática que o uso da tutela coletiva tem nos EUA, o que, de um jeito ou de outro, também é resultado do avanço da legislação existente, seja pela longevidade de tal legislação, que já possui quase um século de existência, contando com as reformas havidas no século $\mathrm{XX}^{99}$.

Importante salientar, que apenas uma legislação forte não gera todos os resultados esperados num ambiente cultural avesso às proposições contidas em tal lei, mas, pouco adianta haver apenas um ambiente cultural propício ao desenvolvimento de um contexto jurídico, sem a existência de norma que discipline tal conjuntura; com base em tal premissa, pressupõe-se a importância da Rule 23 para o papel de destaque dos EUA no cenário do processo coletivo mundial, apesar dessa norma atuar em conjunto com um discernimento cultural muito mais propício a esse desenvolvimento.

Nesse contexto, a importância de uma análise e compreensão do sistema norte americano de classactions, disciplinado pela Rule 23, se deve ao fato de se acreditar que, por meio dessa experiência, conseguiremos construir boas justificativas para o estudo da coletivização de demandas individuais e encontrar boas respostas para os desafios que essa técnica enfrentaria.

Destarte, por se entender as classactions como um modelo eficiente de tutela dos direitos coletivo, buscou-se neste tópico o seu estudo, para que preceitos importados daquela seara contribuam com, por exemplo: o momento de o juiz analisar a admissibilidade da conversão de uma demanda individual em coletiva, a forma de se discernir e classificar a ação coletiva em concreto, e a forma de se decidir sobre a coletivização ou não.

\footnotetext{
${ }^{98}$ Janet Cooper ALEXANDER.“'An introduction to Class Actions Procedure in the United States”.Disponível em:http://law.duke.edu/grouplit/papers/classactionalexander.pdf, p. 20.

${ }^{99}$ PACE, op. cit. p. 02 , nota 96.
} 
O estudo dos prerequisites das classactions, inegavelmente, podem contribuir, fornecendo bases para auxiliar no juízo de admissibilidade que o juiz brasileiro faz sobre as ações coletivas (mormente nas hipóteses em que ele tiver de converter uma ação individual em coletiva), discussão que no Brasil se resume muito em torno do instituto da legitimidade processual, ignorando outros importantíssimos como a numerosidade e a comunidade, por exemplo.

Já o estudo dos tipos de classactions, ajuda muito na compreensão dos tipos de ações coletivas que podem se manejadas no Brasil, onde também se tem uma dicotomia que desagua nas demandas versando sobre direitos indivisíveis e nas demandas versando sobre direitos individuais homogêneos, apesar da profunda diferença na forma de previsão normativa.

Outrossim, a compreensão da certificationorder ou da decisão que julga se uma demanda pode prosseguir ou não como coletiva, fatalmente pode proporcionar conhecimento útil ao aprimoramento da decisão judicial brasileira sobre a matéria (especialmente quando tal decisão for tomada convertendo ação individual em coletiva), ponto que também não é objeto de estudos mais detalhados em nosso sistema, pelo menor destaque que se dá a certificação aqui, que se identifica com o exame da petição inicial.

De todo o modo, a previsão norte-americana de que o juiz deverá definir a classe, os seus pedidos e fundamentos ou defesa, podendo isto ser alterado em qualquer momento antes da decisão final, indica a necessidade de uma especial atenção com esses pontos também na prática brasileira, quando da decisão liminar ou quando da conversão da demanda individual em coletiva.

Nos tópicos seguintes então, serão estudados alguns aspectos relevantes ligados ao uso da tutela coletiva, tais como: os requisitos de admissão, os tipos de classactions e a decisão que recebe tais demandas, com o fim de obtermos algum proveito comparativo de tal análise, para as propostas elaboradas no presente trabalho, mormente ligadas a maior efetividade do processo coletivo, necessidade de modificação do paradigma individualista atual e possibilidade de se coletivizar demandas individuais. 


\subsection{Os requisitos de admissibilidade das classactions(prerequisites)}

A Rule 23 (a) (1 ao 4), estabelece algumas exigências para que uma demanda seja recebida como uma classaction, sem as quais a demanda só poderá prosseguir individualmente, em proveito apenas do proponente ${ }^{100}$.

Tais requisitos visam a impedir o uso desnecessário ou nocivo da tutela coletiva, que prejudique os seus genuínos fins ou a coletividade afetada pelas decisões que serão tomadas, e podem ser definidos pelas seguintes expressões: numerosidade, comunidade, tipicidade e representação adequada.

A numerosidade nada mais é que uma exigência para que a tutela coletiva não seja utilizada na hipótese de poucas partes envolvida, ou seja, desnecessariamente, já que, em tais situações se prefere permitir a participação individual nas demandas ${ }^{101}$.

Nem a lei nem os precedentes estabelecem um número exato para que a demanda seja admitida como coletiva, variando conforme as circunstâncias do caso concreto ${ }^{102}$. Em algumas situações, precedentes autorizam o uso de classactionscom dezoito ou mais partes e, em outras, precedentes indicam a tutela coletiva para casos com 35 ou mais partes ${ }^{103}$, sendo importante para a decisão as características dos casos.

Na legislação brasileira não existe norma fixadora de número mínimo de partes para o uso de uma tutela coletiva, havendo apenas regras definidoras das hipóteses de direitos difusos, coletivos ou individuais homogêneos, às quais devem se subsumir os casos concretos para que a demanda coletiva seja visualizada como possível, todavia,

\footnotetext{
${ }^{100}$ Charles R. FLORES ."Appealing Class Action Certification Decisions Under Federal Rule Of Civil Procedure 23(F),"Setton Hall Circuit Review, p. 04. Disponível em: http://erepository.law.shu.edu/circuit_review/vol4/iss1/2. Segundo o autor: "Failure of a class to meet the Rule 23(a) and (b) requirements does not necessarily end the action enterely, because courts denying class certification may allow the suit to continue against individually named litigants."Emsentidoconvergente: ALEXANDER, op. cit. p. 06, nota 97. Segundo aautora: "If the class is not certified, the plantiff may continue the suit to determine his individual claim, but may not represent the class."

${ }^{101}$ Charles DONELAN. "Prerequisites to a Class Action Under New Rule 23.”10 B.C.L. Rev., p. 529-530, Disponível em: http: //lawdigitalcommons.bc.edu/bclr/vol10/iss3/6.

${ }^{102}$ Ibid.,pag. 531. O autorcita um precedentedeclaradoporJudge Waterman, segundo o qual: "(C)ourts should not be so rigid as to depend upon mere numbers as a guideline on the praticability of joinder; a determination of practicability should depend upon all the circumstances surroudin a case."

${ }^{103}$ Ibid.,pag. 531. Complementando: Janet Cooper ALEXANDER.“An introduction to Class Actions Procedure in the United States".Disponível em:http://law.duke.edu/grouplit/papers/classactionalexander.pdf, p 04. Segundo aautora: "Classes have been certified with as few as 35 members, but normally there are hundreds, thousands or even millions of persons in the class."
} 
parece salutar que a jurisprudência estabeleça algumas disciplinas que recusem a demanda coletiva quando houver poucas partes, pela sua desnecessidade.

A comunidade é relativa à identidade de questões fáticas ou jurídicas, que faz as partes compartilharem dos mesmos interesses, permitindo que haja um julgamento coletivo para todos os representados ${ }^{104}$.

Nos casos disciplinados pela Rule 23 (b) (3), a comunidade de questões deve ser somada à predominância das questões comuns sobre as individuais e à superioridade da tutela coletiva sobre os mecanismos individuais, o que, segundo as letras (b) 3 (A) (B) (C) (D) da norma alienígena, será examinado levando-se em conta os seguintes aspectos do caso concreto: a) o interesse dos membros da classe em controlar a demanda ou a defesa em processo separados; b) a extensão e natureza de cada litigio em relação a controvérsia já instaurada pela ou contra a classe; c) as vantagens e desvantagens de se concentrar todo o processo num único fórum; e d) as prováveis dificuldades no manuseio da classaction $^{105}$.

Essa análise costuma impor óbices ao uso das classactions nos casos de masstorts, ou seja, danos de massa ${ }^{106}$, como por exemplo, os envolvendo malefícios à saúde causados pelo uso ou pela exposição a um produto nocivo.

Em tais casos, as particularidades de cada vítima influenciam muito a caracterização do nexo causal e a fixação do valor das indenizações, o que pode tornar a forma coletiva inapropriada para a resolução da lide, mormente se considerarmos que, pela Rule 23, as indenizações serão fixadas na sentença coletiva, para todas as classes ou subclasses que o juiz pode criar $^{107}$, e não mediante liquidação individual de sentença coletiva genérica, como ocorre no Brasil.

Por outro lado, a comunidade de questões também será dificilmente verificada nas demandas onde os membros da classe representada estão dispersas em Estados diferentes, disciplinados por legislações distintas ${ }^{108}$.

\footnotetext{
${ }^{104}$ Ibid., pag. 532. Na mesma direção: Nicholas M. PACE. "Class Actions in the United States of America: an overview of the process and the empirical literature."Disponível em: http://globalclassactions.stanford.edu/sites/default/files/documents/USA_National_Report.pdf, p 07.

${ }^{105}$ Disponível em: www.law.cornell.edu/rules/frcp/rule_23.

${ }^{106}$ ALEXANDER, op. cit. p. 04-05, nota 102. Convergindo: PACE, op. cit. p. 13-15, nota 103.

${ }^{107}$ Ibid., p. 7 e 14-15 (ALEXANDER).

${ }^{108}$ PACE, op. cit. p. 12 , nota 104.
} 
No Brasil, a análise da comunidade de questões se confunde com a própria análise das hipóteses de direitos coletivos, de modo que, havendo algum interesse difuso, coletivo stricto sensu ou individual homogêneo, haverá a presença da comunidade de interesses, sendo importante também, a predominância de questões comuns, ao menos para parcela respeitável da doutrina ${ }^{109}$.

A tipicidade está relacionada com a legitimidade individual autorizada no sistema norte-americano, onde cada indivíduo está legitimado a propor uma demanda coletiva e a representar os substituídos, desde que pertença a classe defendida, ou seja, desde que tenha relação com os fatos narrados e pretenda para si também os efeitos esperados com a

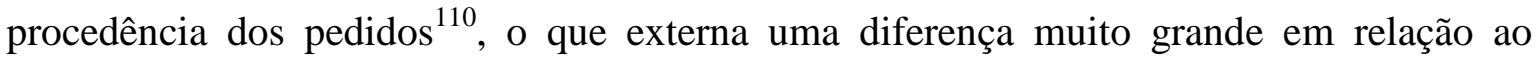
ordenamento pátrio, onde apenas se fala na legitimidade individual expressamente nos casos das ações populares, apesar das criticas merecidas por tal restrição, conforme se verá no andamento do trabalho.

Nada obstante, a tipicidade tem relação com a representatividade adequada, pois o legislador americano partiu da premissa, que o representante só agirá com toda a diligência possível, quando tiver interesse seu também em jogo ${ }^{111}$.

A razão seguida pela legislação americana é necessária e adequada, não gerando qualquer obstáculo ao acesso à justiça, mas sim uma maior segurança no uso da tutela coletiva, o que é uma grande preocupação para os nortes americanos, já que as classactions podem afetar a direitos individuais que não tenham sido excluídos por meio do opt out, meio pelo qual, apenas nas ações certificadas soba Rule 23 (b) (3) $)^{112}$, os indivíduos pertencentes à classe podem optar por não serem afetados pela decisão coletiva, nem para se beneficiar nem para se prejudicar; nos demais casos, toda a classe será afetada não havendo a possibilidade de auto exclusão ${ }^{113}$.

\footnotetext{
${ }^{109}$ GAGNO, Luciano P. "Direito individual homogêneo: em busca de uma interpretação mais coerente com o direito fundamental de acesso à justiça”, p. 252 . Disponível em: http://www.conpedi.org.br/manaus/arquivos/anais/brasilia/12_619.pdf.

${ }^{110}$ DONELAN, op. cit. p. 534, nota 101.Concordando: PACE, op. cit. p. 7, nota 104.

${ }^{111}$ Ibid., p. 534 (DONELAN).

${ }^{112}$ ALEXANDER, op. cit. p. 08-09, nota 103.

${ }^{113}$ PACE, op. cit. p. 10, nota 104. Segundo o autor: "One important aspect $f$ cases certified under Rule 23 (b) (2) as well as Rule 23 (b) (1) (A) is that judges are not required to give class members the option to exclude themselves. This is because the nature of any equitable relief that might be ordered (such as injunction prohibition discriminatory admission policies) would, at least in theory, be indivisible and work to the benefit of all who met the class definition". Nada obstante, a professora JANET COOPER ALEXANDER entende
} 
Caso se aceite ou se preveja a legitimação individual para ações coletivas no Brasil, o que foi almejado nos anteprojetos de Código de Processo Coletivo, também será necessário o atendimento a tipicidade ${ }^{114}$, já que ela é um importante mecanismo de se tentar assegurar uma representatividade adequada.

Por fim, a representatividade adequada é um pressuposto muito mais relacionado aos predicados dos advogados que atuarão no feito, do que às características da parte substituta, conforme se percebe em precedente citado pelo autor americano Donelan, que analisa essa questão ressaltando os seguintes adjetivos para a sua caracterização: competência, experiência e demais condições para conduzir uma demanda coletiva ${ }^{115}$.

A competência chega-se a dizer que deve ser presumida em favor de todo advogado habilitado, mas a experiência, por obvio, dependerá de atuações pretéritas e, a sua capacidade econômica dependerá dos advogados terem recursos para arcar com todas as despesas processuais, até a realização de um setlementou a obtenção de um julgamento favorável, quando serão ressarcidos pelas despesas e pelo trabalho; nos casos envolvendo civil rights, por exemplo, onde pode não haver resultado monetário, pode-se impor ao réu derrotado a obrigação pelos pagamentos dos honorários e demais despesas ${ }^{116}$.

No Brasil, a representatividade adequada também foi prevista no anteprojeto de Código de Processo Coletivo ${ }^{117}$, entretanto, temos receio de que uma norma com tal conteúdo seja manipulada para atender a fins reprováveis, de óbice ao acesso à justiça, mormente porque a ausência de recursos para prover as despesas processuais jamais poderia influenciar a admissibilidade de uma ação, na perspectiva jurídica constitucional estabelecida em nosso sistema.

Fazendo uma relação entre os prerequisites, a situação teórica e prática brasileira,e a tese elaborada neste trabalho, de coletivização de demandas individuais, parece forçoso concluirmos que, antes de proceder coletivizando uma demanda individual, o juiz competente necessariamente deverá identificar se está presente alguma modalidade de

que mesmo em tais casos, deveria haver a informação das partes ausentes, ao menos para que elas saibam da existência da demanda e tenham alguma chance de participar, se quiserem. Neste sentido: ALEXANDER, op. cit. p. 08, nota 103.

114 Anteprojeto de Código Brasileiro de Processos Coletivos. In: Ada Pellegrini GRINOVER;ALuisio Gonçalves de Castro MENDES;Kazuo WATANABE (Coord.). Direito processual coletivo e o anteprojeto de Código Brasileiro de Processo Coletivos, p. 456.

${ }^{115}$ DONELAN , op. cit. p. 535, nota 101. No mesmo sentido: ALEXANDER, op. cit. p. 6, nota 103.

116 ALEXANDER, op. cit. p. 10-11, nota 103.

${ }^{117}$ Anteprojeto de Código Brasileiro de Processos Coletivos, op. cit. p. 456, nota 114. 
direito coletivo lato sensu, assim como deve ocorrer quando da análise de uma petição inicial de uma ação coletiva, devendo ainda decidir sobre a numerosidade da classe, que justifique o modelo coletivo de solução de crises; a comunidade dos seus interesses se confunde com a análise da espécie de direito coletivo.

Outrossim, a tipicidade se fará importante por se confundir com a necessária análise da legitimidade ordinária, supondo que o individuo seja aceito como autor; já a representatividade adequada, deverá mais se alinhar a uma analise da boa-fé das partes, do que da capacidade delas desempenharem um bom trabalho, tendo em vista o modelo social democrático de acesso à justiça típico do nosso modelo constitucional.

\subsection{As hipóteses genéricas em que se admitem as classactions (typesofclassactions)}

Diferentemente do que ocorre no Brasil, nos Estados Unidos as hipóteses de demandas coletivas possuem uma previsão muito mais voltada às situações práticas em que a tutela coletiva seria necessária ou útil, que a conceitos jurídicos por meio dos quais sejam definidos os tipos de direitos a serem protegido.

Ao invés do legislador norte-americano trabalhar com conceitos como direitos difusos, coletivos ou individuais homogêneos, diferenciando cada um pela sua natureza e pelo vinculo que unirá a coletividade entre si e com a parte contrária, ele estabeleceu situações abstratas em que o uso da tutela coletiva será necessário por uma questão de isonomia, de se evitar conflitos entre decisões judiciais ou para se indenizar danos causados à coletividade, ou seja, no centro das hipóteses de classactions estão as ideias de: igualdade, coerência e reparação por danos.

A doutrina costuma dividir os tipos de classactions em dois grandes grupos: o primeiro, constituído pela Rule 23 (b) (2) e Rule 23 (b) (1) (A), é utilizado nas hipóteses em que se pretendem medidas injuntivas ou declaratórias, com o fim de se obter reformas institucionais, mudanças nas politicas sociais ou a proteção dos civilrights; o segundo, constituído pela Rule 23 (c) (3) ou Rule 23 (b) (1) (b), é utilizados principalmente com o 
objetivo de obter compensações financeiras, ligados basicamente a pedidos de indenização $^{118}$.

Dessa maneira, uma hipótese de classaction, prevista pela Rule 23 (b) (2), é quando o demandado se recusa a proceder da mesma maneira com as diferentes partes com quem ele possua algum tipo de relação jurídica, o que justifica o uso de injunções tendentes a obrigar que o réu atue de maneira isonômica com os substituídos ${ }^{119}$.

Por meio dessa norma é que ações coletivas versando sobre direitos sociais, como a que garantiu a estudantes negros o fim da segregação racial nas escolas, foram certificadas, já que nesse caso, a causa de pedir era justamente a recusa do sistema de educação da cidade de Topeka, Estado do Kansas, em aceitar uma criança negra, sob a alegação de que os negros eram "separados mas iguais" 120.

Na outra hipótese de classactions, prevista na Rule 23 (b) (1) (A), tem-se os casos em que a tutela coletiva visa a impedir conflitos entre decisões judiciais relativas a indivíduos pertencentes à classe, que estabeleceriam condutas incompatíveis a serem observadas pela parte contrária ${ }^{121}$, fazendo com que o autor Pace afirme que tais tipos de ações trazem também beneficio ao réu ${ }^{122}$.

A norma em foco possui uma sintonia muito parecida com a norma anterior, tanto é assim, que doutrinadores sustentam a similaridade entre elas, dizendo que muitas demandas poderiam ser certificadas por ambas ${ }^{123}$.

Para se exemplificar casos certificados pela norma em questão, pode-se citar a demanda, por meio da qual, jogadores profissionais de futebol americano reivindicaram mudanças nas regras da liga ${ }^{124}$.

\footnotetext{
${ }^{118}$ Nicholas M. PACE. "Class Actions in the United States of America: an overview of the process and the empirical literature.Disponível em: http://globalclassactions.stanford.edu/sites/default/files/documents/USA_National_Report.pdf, p 07.

${ }^{119}$ Segundo o texto da Rule 23 (b) (2): "the party opposing the class has acted or refused to act on grounds that apply generally to the class, so that final injunctive relief or corresponding declaratory relief is appropriate respecting the class as whole.” Disponível em: www.law.cornell.edu/rules/frcp/rule_23.

120“'Brown v. Board of Education.”Disponível em: https://supreme.justia.com/us/347/483/case.html.

${ }^{121}$ Segundo o texto da Rule 23 (b) (1) (A): “(1) prosecuting separate actions by or against individual class members would create a risk of: (A) inconsistent or varying adjudications with respect to individual class members that would estabilish incompatible standards of conduct for the party opposing the class; or". Disponível em: www.law.cornell.edu/rules/frcp/rule_23.

${ }^{122}$ PACE, op. cit. p. 10, nota 118.

${ }^{123}$ Ibid., p. 09-10.
} 
Nesse sentido, o autor Pace sustenta que os dois dispositivos acima estariam ligados a tutela de direitos indivisíveis, razão pela qual, como dito no tópico acima, não se exige a informação a todos os afetados nem se outorga a opção de opt out.

As duas normas acima referidas são amplamente utilizadas para a proteção dos "civilrights" e a obtenção de mudanças sociais, e de reformas institucionais em segmentos estatais ligados a funções que são prestadas de maneira patológica, merecendo a intervenção judicial para se adequar à lei e à constituição, sendo que o foco da reforma da Rule 23 em 1966 foi justamente o de se aperfeiçoar a tutela de tais direitos ${ }^{125}$.

Por fim, a Rule 23 (b) (3) prevê o uso das classactions, na hipótese em que as questões de fato ou direito relativas à classe predominem sobre as questões individuais, constituindo a demanda coletiva um meio mais eficiente que os demais para resolver o respectivo conflito ${ }^{126}$, o que no Brasil corresponde à ação coletiva para tutela de direitos individuais que tenham uma origem comum, ou seja, os direitos individuais homogêneos.

Nesse caso, como visto acima, a regra dispõe que a admissibilidade de uma ação coletiva por danos fica subordinada à presença de mais dois requisitos, quais sejam: predominanceou predominância de questões comuns sobre as individuais, e superiority, que é a superioridade da via coletiva sobre a individual, ou seja, a ação coletiva tem que se apresentar como um meio mais viável do que o individual para a resolução dos conflitos $\operatorname{agregados}^{127}$.

Essas regras em diversas situações restringem o uso da tutela coletiva nos casos de masstorts, sendo questionável para nós esse obstáculo, que talvez se mostre mais razoável nos E.U.A., onde, como visto, as sentenças coletivas fixam os valores da indenização num todo, sendo inviável a fixação de valores individuais, razão pela qual, muitas vezes, apenas

\footnotetext{
${ }^{124}$ Ibid., p. 10.

${ }^{125}$ Ibid. p. 08.Convergindo: JoEllen LIND. ''Procedural Swift': Complex Litigation Reform, State Tort Law, and Democratic Values."p. 758. Disponívelem: http://www.classactionlitigation.com/library/lind37.4.pdf.

${ }^{126}$ Segundo a Rule 23 (b) (3): "the court finds that the questions of lae or fact common to class members predominate over any questions affecting only individual members, and that a class action is superior to other available methods for fairly and efficiently adjudicating the controversy." Disponível em: www.law.cornell.edu/rules/frcp/rule_23.

127 Janet Cooper ALEXANDER. "An introduction to Class Actions Procedure in the United States”.Disponível em:http://law.duke.edu/grouplit/papers/classactionalexander.pdf, p. 05. Vertambém: Nicholas M. PACE."Class Actions in the United States of America: an overview of the process and the empirical literature.Disponível em: http://globalclassactions.stanford.edu/sites/default/files/documents/USA_National_Report.pdf, p. 12-13.
} 
a via individual consegue abranger as particularidades das ações indenizatórias, ligadas principalmente as características das vitimas.

Nada obstante, deve-se registrar que a onda de restrição às ações coletivas nesses casos é variável, podendo-se dizer que foi intensa na década de setenta, aliviada na de oitenta, mas revivida de maneira ambivalente nos tempos atuais ${ }^{128}$, destacando-se também, que em muitos casos a comoção social que há subjacente ao caso, influencia na decisão e cria uma vertente de precedentes que se esforçam por ampliar a admissão das ações coletivas por danos, inclusive criando teorias de responsabilidade civil que reduzam o ônus da prova para as vítimas ou o transfiram para o réu ${ }^{129}$.

As ações coletivas certificadas pela norma em foco, geralmente pretendem uma compensação financeira para reparação de algum dano, contudo, ações coletivas visando à compensação financeira podem também ser certificadas sob a Rule 23 (b) (1) (B), que, todavia, é bem menos utilizado na prática, pois tem em sua redação o foco voltado para hipóteses em que não há suficiência de recursos para se adimplir todas as indenizações, hipótese que, na maioria dos casos é preterida pelas ações de falência ${ }^{130}$.

Por fim, é interessante lembrar a existência das ações híbridas, que envolvem tanto a busca por medidas declaratórias ou injuntivas, como também pedidos indenizatórios, havendo, por vezes, numa mesma lide, subclasses que anseiam o alcance de medidas de equidade para estancar tratamentos desiguais ou risco de divergências, e outras que visam à reparação de $\operatorname{danos}^{131}$.

Para a conversão de uma demanda individual em coletiva, o nosso juiz deverá se atentar sobre o tipo de direito coletivo lato sensu é objeto da demanda, ou seja, se se trata de uma ação pseudoindividual, convertida em coletiva por versar sobre um direito difuso ou coletivo stricto sensu, ou se se trata de uma ação versando sobre um direito individual

\footnotetext{
${ }^{128}$ PACE, op. cit. p. 13-14, nota 127.No mesmo sentido: LIND, op. cit. p. 757, nota 125. Segundo aautora: "Although under Federal Rule 23, damage class actions are hardest to certify, parties and trial judges often want them to be certified to achieve na administrative regime for dealing with thousands of claims that would clog the courts if brought individually. [...]. In fact, the attitude of the federal courts toward class actions is ambivalent."

${ }^{129}$ ALEXANDER, op. cit. p. 22, nota 127. Segundo aautora: "When courts perceive class actions as a beneficial way of handling certain types of claims, thei may interpret the substantive law to facilitate class certification. [...]. In response to this problem, the courts developed the "fraud on the market" doctrine, under wich reliance and causation are presumed if the misrepresentation or omission was material. This doctrine has made it significantly easier to prove a violation."

${ }^{130}$ PACE, op. cit. p. 11 e 15, nota 127.

${ }^{131}$ Ibid., p. 24-25.
} 
com origem comum a de outros direitos individuais, ou seja, um direito individual homogêneo, merecedor de ser coletivizado para se evitar as milhares de demandas repetitivas que provavelmente surgirão.

De maneira parecida com o sistema norte-americano, essa identificação se mostra fundamental, pelas diferenças existentes nos procedimentos ligados a cada categoria de direito, se indivisível ou divisível, principalmente no que tange a extensão da coisa julgada.

\subsection{A decisão que certifica a ação como uma classaction (certificationorder)}

$\mathrm{Na}$ decisão por meio da qual se certifica uma classactions, além de todos os aspectos acima mencionados, relativo aos requisitos de numerosidade, comunidade, tipicidade, representação adequada, e predominância e superioridade da tutela coletiva nos casos envolvendo indenização, obviamente que a Corte deverá examinar também em qual tipo de ação coletiva o caso concreto se encaixa.

Caso a Corte verifique que se trata de uma classactions for damages, deverá haver a notificação de cada possível interessado, para exercer o direito de opt out caso não queira ser abrangido pela decisão judicial, comunicação que, para alguns autores, deveriam ocorrer em todas as hipóteses, senão para permitir a auto exclusão, ao menos para permitir algum tipo de participação e acompanhamento ${ }^{132}$.

A decisão sobre a certificação deverá ocorrer o quanto antes, ou no inicio do procedimento, ou após a realização de um pre-certificationdiscovery, muitas vezes necessário para que seja aferida a presença dos requisitos acima mencionados em concreto, quando os autores narram a ocorrência de uma antecipação do conhecimento de algumas questões mérito, o que, em alguns casos acaba sendo útil posteriormente ${ }^{133}$.

Ademais, a decisão que certifica uma ação como classaction pode ser alterada ou emendada a qualquer tempo antes do julgamento final, caso a Corte se convença

\footnotetext{
${ }^{132}$ ALEXANDER, op. cit. p. 08, nota 127.

${ }^{133}$ Marc D. ASHLEY. "The scope and timing of discovery in antitrust class action litigation."The Antritrust Practitioner, p. 15. No mesmosentido: Joshua B. GRAY; Michelle H. SEAGULL. "Class Action Reaction: Amended Rule 23 Enhances Judicial Supervision in Class Litigation.”Antitrust, p. 92.
} 
posteriormente pela presença, ausência ou perda dos requisitos que outrora foram identificados $^{134}$.

Caso não haja certificação, a parte poderá prosseguir com sua pretensão individual, bem como recorrer a instância superior mediante uma apelação interlocutória, cabível após alterações legislativas que tiveram este escopo ${ }^{135}$.

Apesar da decisão sobre a certificação não ser uma decisão final sobre o caso, ela pode representar uma barreira intransponível, nas hipóteses em que não há interesse econômico no prosseguimento individual não certificada, já que muitas dessas ações envolvem quantias que, se analisadas individualmente, se mostram ínfimas ${ }^{136}$.

Obviamente, o contraditório prévio é fundamental para que seja certificada uma decisão e, em grande parte dos casos, após a certificação o requerido realiza ou ao menos propõe a realização de um setlement, ou seja, um acordo, a fim de evitar uma dupla perda, quais sejam, uma condenação aliada aos custos altíssimos de condução de uma classaction, realidade que, diga-se de passagem, estimulou o ajuizamento de ações temerárias ${ }^{137}$.

Certificada uma demanda como classaction, caberá a Corte definir a classe, suas reivindicações, questões ou defesas, o que é fundamental para o possível exercício do direito de apelar da decisão ${ }^{138}$, e apontar o conselho de classe, que, composto pelos advogados dos representantes da classe, será responsável pela adequada representação das partes ausentes, motivo pelo qual a Corte deverá considerar: a) o trabalho previamente realizado na identificação ou investigação dos direitos reivindicados, b) a experiência em demandas coletivas, em casos complexos ou em casos de direitos similares, c) o conhecimento da lei a ser aplicada, e d) os recursos para conduzir a demanda coletiva ${ }^{139}$.

No Brasil, para a admissão de uma demanda coletiva, caberá ao juiz, principalmente, examinar se o caso concreto se enquadra nas hipóteses de direitos

\footnotetext{
${ }^{134}$ GRAY; SEAGULL, op. cit. p. 93, nota 133.

${ }^{135}$ Jeffrey G. WEIL; Brian KINT. “Rule 23(f) Class Certification Appeals: Boon or Bust?”The Legal Intelligencer. ALM Media Properties, LLC. Disponível em: http://www.law.com/jsp/pa/PubArticleFriendlyPA.jsp?id=1202548299218, p. 01.

${ }^{136}$ Ibid., p. 02. No mesmo sentido: JoEllenLIND. "'Procedural Swift': Complex Litigation Reform, State Tort Law, and Democratic Values", disponívelem: http://www.classactionlitigation.com/library/lind37.4.pdf, p. 760 .

${ }^{137}$ Janet Cooper ALEXANDER."An introduction to Class Actions Procedure in the United States".Disponível em:http://law.duke.edu/grouplit/papers/classactionalexander.pdf, p. 20.

${ }^{138}$ GRAY; SEAGULL, op. cit. p. 93, nota 133.

${ }^{139}$ Ibid., p. 93.
} 
coletivos lato sensu previstas no CDC, além da questão da legitimidade que, prevista em lei, a priori, dispensa o juiz da análise da representação adequada, apesar de algumas vozes discordantes a esse respeito ${ }^{140}$.

Nada obstante e traçando uma relação com a tese apresentada no este estudo, devese registrar que, se aceita a tese de uma decisão que converta uma ação individual em coletiva, seria fundamental que o juiz também, ao justificar a sua providência, definisse a classe relativa ao direito visualizado, a pretensão que abrange essa classe e os fundamentos dessa pretensão (o que vai depender da identificação do tipo de direito coletivo objeto da ação), além dos demais requisitos que já foram falados acima, tais como: a legitimidade, o tipo de direito coletivo e a necessidade da coletivização pela numerosidade da classe.

O dever de fundamentação judicial ora discutido tem a múltipla função de permitir aos tribunais um melhor ofício nos casos em concreto, à sociedade mais transparência e sensação de legitimidade, e às partes o direito substancial de participar e interferir no processo, principalmente recorrendo contra o julgado.

\section{A EXISTÊNCIA DE TÉCNICAS SIMILARES NO SISTEMA}

\footnotetext{
${ }^{140}$ Susana Henriques da COSTA. In: Ação Popular, p. 390-391. (Coord.). Comentários à Lei de Ação Civil Pública e Lei de
} 


\subsection{A técnica de extensão da sentença normativa na justiça do trabalho}

Na justiça do trabalho existe há muito a técnica de resolução de dissídios coletivos, que são demandas instauradas por sindicatos de categorias econômicas ou profissionais ${ }^{141}$, após uma tentativa de negociação ${ }^{142}$, visando à modificação das condições de trabalho (de natureza econômica) ou a interpretação das normas pertinentes à determinada categoria econômica e profissional (de natureza jurídica), ou a paralisação das atividades ${ }^{143}$.

Como resultado do dissídio poderá haver tanto a homologação de um acordo como o julgamento do pleito coletivo, mediante sentença normativa, que se aproxima da atividade legislativa $^{144}$, mas não se confunde com esta, podendo operar apenas no seu vácuo e respeitado o limite constitucional, que atribui exclusivamente à lei,a função de regulamentar algumas matérias ${ }^{145}$, sendo certo que, sendo normativa, essa sentença cria uma regra em abstrato para todos os que pertençam ou venham a pertencer a determinada categoria profissional, possuindo um prazo de validade que poderá variar de um a quatro $\operatorname{anos}^{146}$.

Até aí não se tem muita novidade, vez que o dissídio coletivo se aproxima das demandas coletivas tradicionais, com algumas diferenças, como o fato de ser ajuizada em segunda instância.

A técnica em questão começa a ganhar maiores contornos de particularidade, se aproximando, em alguma medida, da técnica de coletivização de demandas individuais, quando prevê a possibilidade de se estender os efeitos dessa sentença normativa para todos

\footnotetext{
${ }^{141}$ Francisco AntonioOLIVEIRA. Comentários à Consolidação das Leis do Trabalho.p. 859.

${ }^{142}$ Ives Gandra MARTINS FILHO. Manual esquemático de direito e processo do trabalho,p. 185. No mesmo sentido:Ibid., p. 859. Os autores esclarecem, que apenas o dissídio coletivo de natureza econômica, ou seja, que visa à modificação das condições de trabalho, necessita da negociação prévia como um pressuposto processual de validade.

${ }^{143}$ Ibid., p. 182. (MARTINS FILHO). A doutrina dominante classifica as principais espécies de dissídios em dois grupos apenas, quais sejam: a) dissídios jurídicos ou de natureza jurídica, quando se pretende a aplicação ou interpretação de alguma norma jurídica trabalhista; b) e os dissidio de interesse ou de natureza econômica, quando se pretende a alteração de alguma condição de trabalho. Neste sentido: Amauri Mascaro NASCIMENTO. Curso de direito processual do trabalho, p. 643. E também: Francisco Ferreira JORGE NETO; Jouberto de Quadros Pessoa CAVALCANTE. Direito Processual do Trabalho, p. 1123-1124.

144 NASCIMENTO, op. cit. p. 639, nota 142. Segundo o autor: "Calamandrei observa que os pronunciamentos da magistratura nos processo coletivos são, em seu conteúdo, a expressão de poderes normativos absolutamente similares àqueles que ordinariamente exercem os órgãos legislativos."

${ }^{145}$ Ibid., p. 635-636.

${ }^{146}$ Wagner D. GIGLIO. Direito processual do trabalho, p. 427.
} 
os empregados que forem da mesma profissão em uma determinada empresa, quando o dissidio envolver apenas parte deles, ou ainda, de se estender os seus efeitos para todos aqueles que pertençam à categoria profissional, dentro dos limites territoriais de atuação do respectivo tribunal, em limitação que precedeu restrição similar colocada na LACP.

Essa extensão somente será admitida em se tratando de dissidio coletivo de natureza econômica, ou seja, que vise à alteração das condições de trabalho de um grupo de trabalhadores, havendo procedimentos bem diferentes para se alcançar os resultados acima previstos.

Primeiramente, em se tratando de dissídio coletivo que abranja apenas alguns empregados de uma mesma empresa, seja porque esta possui setores não mencionados na inicial, seja porque ela possui filiaistambém omitidas, a extensão dos efeitos da decisão poderá ocorrer de oficio, na própria decisão do Tribunal sobre o dissídio ${ }^{147}$.

Na segunda hipótese, em que se pretende a extensão dos efeitos da decisão para toda a categoria profissional, de modo a envolver também toda a categoria econômica, aí já se estabelece um procedimento mais rigoroso, que exige um consentimento prévio de $3 / 4$ dos empregadores e 3/4 dos empregados, que deverão ser ouvidos entre 30 a 60 dias, sendo posteriormente seguidos pela manifestação da Procuradoria da Justiça do Trabalho ${ }^{148}$.

Nada obstante, neste segundo caso a iniciativa da extensão também pode ser adotada de oficio pelo próprio Tribunal.

Percebe-se assim, a já existência no sistema, de técnica que, apesar de não coletivizar demanda individual, permite a extensão dos efeitos da decisão para além dos limites subjetivos conhecidos, de oficio, ou seja, por iniciativa do próprio Judiciário, sem que se questione, sobre tal possibilidade, o possível autoritarismo de tal poder ou a violação àprincípios constitucionais como o contraditório e o juiz natural, ou até infraconstitucionais como os princípios da demanda ou da adstrição da sentença ao pedido.

Tanto no caso da proposta em tela, como no caso da técnica trabalhista ora estudada, tem-se situações massificadas, que são resolvidas pelo Judiciário, mediante a extensão dos efeitos da decisão proferida num caso para pessoas que se situam fora de sua formatação inicial.

\footnotetext{
${ }^{147}$ Ibid., p. 422. Em sentido similar: Sérgio Pinto MARTINS. Direito processual do trabalho: doutrina e prática forense. p. 673.

${ }^{148}$ Ibid., p. 423.
} 
Tanto num caso como no outro, deve estar presente uma homogeneidade suficiente que permita tal extensão, já que a CLT exige em seu artigo, que a extensão abarque apenas "empregados da empresa que forem da mesma profissão" ou, sendo de outras empresas, que pertençam à mesma "categoria profissional"149.

Ao que nos parece, as premissas que justificam tal técnica trabalhista são as mesmas que justificam a tese ora proposta, ou seja, o grande volume de demandas repetitivas, baseadas nos mesmos fatos e/ou fundamentos jurídicos, nas quais os direitos invocadospossuem origem comum (homogêneos), merecendo um julgamento mais racionalizado, que dispense atividades repetitivas desnecessárias e proporcione decisões uniformes e isonômicas, para todos que se enquadrem naquela situação massificada.

Pode-se concluir então, que a técnica trabalhista em comento concede algum amparo a presente tese de coletivização de demandas individuais, na medida em que, tanto num caso como no outro, tem-se a ampliação subjetiva dos efeitos da sentença por meio de decisão judicial, que independe de provocação, sem que tenham sido levantados maiores questionamentos sobre a constitucionalidade, operacionalidade e efetividade de tal instrumento, queserve até os presentes dias como uma ferramenta útil ao Poder Jurisdicional Trabalhista.

\subsection{A súmula vinculante e a sistemática da repercussão geral e dos recursos repetitivos}

Algumas modificações normativas ocorridas no limiar do século XXI parecem estar indicando a existência de uma tendência diferente na forma de atuação do Pode Jurisdicional, que prime mais pela racionalização da atividade e pela segurança jurídica, em detrimento de um modelo exclusivamente individualista, em que se ignora a existência de situações repetitivas.

Essa tendência está expressa nas alterações normativas que introduziram no sistema jurídico atual instrumentos como a súmula vinculante e a sistemática da repercussão geral, e dos recursos especiais repetitivos.

${ }^{149}$ OLIVEIRA, op. cit. p. 801, nota 141. 
Outros instrumentos como o julgamento imediato do pedido, a súmula impeditiva de recursos e a sistemática de julgamento monocrático nos Tribunais, também corroboram com esse tom de coletivização que vem sendo dado ao modelo processual pátrio, entretanto, os instrumentos escolhidos neste tópico, são mais emblemáticos de um formato coletivo de processo, na medida em que representam técnicas aptas a espraiar os efeitos de sua utilização para outros processos, além daquele na qual o instrumento é utilizado.

Assim por exemplo, a súmula vinculante editada em um procedimento, por conta da reiteração daquele posicionamento, envolvendo questão jurídica repetitiva e sobre a qual havia grave divergência, tem o condão de obrigar a observância da interpretação ali cristalizada, em todos os demais processos jurisdicionais ou administrativos em que se discuta a mesma questão ${ }^{150}$.

Em toada similar, a decisão sobre a repercussão geral em um processo será aproveitada aos demais que discutam a mesma questão, e o julgamento adotado em sede de recurso especial repetitivo também repercutirá sobre os demais recursos com a mesma temática.

No caso das técnicas relativas ao julgamento imediato do pedido, à súmula impeditiva ou ao julgamento monocrático dos recursos, a utilização da respectiva técnica produz efeitos restritos ao processo no qual a técnica é utilizada, graças a influência de decisões proferidas em outros processos similares.

Nesse sentido, percebe-se que o legislador brasileiro vem municiando, nos últimos dez anos, o Judiciário brasileiro com técnicas de extensão e aproveitamento de decisões judiciais já proferidas em casos de contornos fáticos e jurídicos similares, no mesmo sentido que vem se propugnando neste trabalho, só que por via diferenciada, qual seja: de uniformização das decisões oriunda dos Tribunais Superiores e de aplicação, senão obrigatória, ao menos recomendada,como nos casos de recursos repetitivos.

Criou-se algo mais próximo do sistema de precedente judicial vinculativo, que não significa estritamente a coletivização do instrumento jurisdicional, o processo, mas que indica a necessidade de uma nova formatação processual, adequada ao volumo estratosférico de litígios de massa, repetitivos, que envolvem fatos e direitos bem parecidos, com origem comum, ao ponto de comportarem julgamento uniformes.

\footnotetext{
${ }^{150}$ Sérgio SHIMURA. "A súmula vinculante como mecanismo de tutela coletiva." Revista Jurídica do Ministério Público do Mato Grosso, p. 118 e 120.
} 
Esses julgamentos, apesar de proferidos em processo individual, vem ganhando eficácia erga omnes e vinculante, ou seja, abstração e generalidade, para serem aplicados em todos os casos que comportem a importação da respectiva tese, justamente pela similaridade fática e jurídica.

Dessas técnicas, a súmula vinculante é uma das mais significativas, já que ela será obrigatoriamente observada pelo Judiciário e todos os órgãos da Administração Pública, direta ou indireta, independentemente da esfera na qual se situarem.

Dessa forma, após reiteradas decisões do STF, sobre matéria que venha sendo decidida de maneira controvertida nos tribunais, a fim de se evitar insegurança jurídica e multiplicação de litígios ${ }^{151}$, a referida corte poderá, pela votação de $2 / 3$ dos seus membros, estabelecer um enunciado contendo a tese jurídica para determinada questão, que deverá ser obrigatoriamente observada pelos demais órgãos do Judiciário e da Administração Pública, sob pena da desobediência ser atacada diretamente pela via da reclamação ${ }^{152}$.

Nesse cenário, tem-se duas constatações a serem feitas: a primeira é que a sumula vinculante se aproxima do que se entende por um mecanismo coletivo de resolução de conflitos, dando, por tanto, um aspecto de razoabilidade a proposta ora elaborada, de coletivização de demandas individuais; a segunda é que, ainda assim, a sumula vinculante não produz os mesmos efeitos que serão produzidos pela coletivização de demandas judiciais e isto, por duas razões básicas.

A primeira é que a súmula não torna desnecessário o ingresso com uma demanda judicial de conhecimento, em caso de sua inobservância, de modo que, ainda que editada súmula, garantindo aos consumidores a nulidade de determinada clausula e o direito a restituição do que foi pago indevidamente, terão eles de ingressar com demandas declaratórias e de cobrança, que serão objeto de contestação e sentença, que poderão ser objeto de apelação e outros recursos, e que, só após o transito em julgado poderão ser definitivamente executadas.

Em se tratando de decisão coletiva já transitada em julgado, o consumidor necessitará de uma liquidação e execução caso não haja o cumprimento espontâneo da decisão, podendo, em determinados casos, como se verá mais adiante, exigir até multa pelo

\footnotetext{
${ }^{151}$ José Miguel Garcia MEDINA; Luiz Rodrigues WAMBIER; Teresa Arruda Alvim WAMBIER. "A súmula vinculante vista como meio legitimo para diminuir a sobrecarga de trabalho dos tribunais brasileiros." Revista Juridica.p. 33. No mesmo sentido: SHIMURA, op. cit. p. 120-121, nota 150.

${ }^{152}$ Ibid., p. 46; Ver também: SHIMURA, op. cit. p. 127, nota 150.
} 
descumprimento da decisão, o que não seria admitido pelo descumprimento de uma súmula.

Além disso, é indiscutível a menor abrangência que a técnica de súmula vinculante possui, na medida em que só poderá versar sobre matéria constitucional, devendo ser criada pela votação de $2 / 3$ do STF, após ser suscitada de oficio ou por algum ente expressamente legitimado.

Vale ressaltar, que tal medida não significa necessariamente mais segurança, pois o suposto risco de se deixar as decisões coletivas nas mãos de juízes de primeiro grau são amenizadas pela possibilidade de diversos recursos e pelo sistema da coisa julgada secundumeventum litis e secundumeventumprobationis.

Dessa maneira, percebe-se que a técnica de vinculação as sumulas do STF, criada no âmbito constitucional, proporciona argumentos para que encaremos a proposta em questão como natural, fruto de uma período em que se busca a racionalização da atividade jurisdicional, ao mesmo tempo em que não torna desnecessária a coletivização de demandas individuais, pelos motivos que acabaram de ser vistos.

Em senda parecida, a sistemática da repercussão geral permite uma objetivação dos julgamentos dos recursos extraordinários que traduzam causas repetitivas, demandas de massa, versando sobre direitos individuais homogêneos ${ }^{153}$, podendo tais recursos ser decididos de maneira coletiva, ou seja, com a prolação de uma única decisão, cuja tese jurídica valerá para todas ${ }^{154}$.

Havendo muitos recursos sobre a mesma questão, a repercussão geral desta será analisada apenas em alguns que representem a controvérsia, de modo que parte dos processos será enviada ao STF, enquanto todo o restante ficará na instância a quo, aguardando o julgamento da instancia competente ${ }^{155}$.

Julgados os recursos extraordinários representativos da controvérsia pelo STF, ficará a cargo do Tribunal a quo retratar-se, caso seu acordão esteja em dissenso com o

\footnotetext{
${ }^{153}$ Luis Alberto REICHELT. “A duração do processo, o julgamento do recurso extraordinário dotado de repercussão geral e a modulação dos efeitos da declaração de inconstitucionalidade.” Revista de Processo,p. $135-138$.

${ }^{154}$ Clarissa Teixeira PAIVA. "A repercussão geral dos recursos extraordinários e a objetivação do controle concreto de constitucionalidade." Revista da AGU,p. 79.

155 Humberto THEODORO JÚNIOR; et al. "Litigiosidade em massa e repercussão geral no recurso extraordinário." Revista de Processo,p. 35.
} 
decidido pelo STF, ou julgar o recurso extraordinário individual prejudicado, caso seu acordão seja mantido pelo $\mathrm{STF}^{156}$.

Naturalmente, caso a decisão do STF seja pela inexistência da repercussão geral, todos os recursos que visavam à discussão da mesma questão serão afetados e, por conseguinte, não conhecidos ${ }^{157}$.

Vê-se novamente, o perfilhamento do legislador a mais uma técnica de objetivação da atividade jurisdicional, pela vinculação de instâncias inferiores às teses jurídicas formuladas pelo STF, com a finalidade de conferir racionalidade ao ofício da Jurisdição, de modo que não se mostrem necessários milhares de julgamentos repetitivos sobre temas idênticos, cujo entendimento já se encontra consolidado pela última instância competente para o seu julgamento.

A sistemática da repercussão geral, contemporânea à técnica da súmula vinculante, externa o anseio da sociedade por uma justiça mais célere e eficiente, que realmente consiga promover seus objetivos em um lapso temporal razoável e, para tanto, a ampliação da eficácia subjetiva das decisões do STF se tornou uma alternativa, já que neste tribunal concentram-se causas de todo o Brasil.

Essas técnicas mostram que a ampliação da eficácia subjetiva da decisão tem se mostrado necessária no atual contexto, em que vem sendo levadas ao Judiciário causas completamente homogêneas, que se baseiam em fatos e direitos muito parecidos.

Não obstante, cumpre ressaltar que a sistemática de julgamento da repercussão geral, apesar de proporcionar uma objetivação da atividade jurisdicional, não torna desnecessária a proposta realizada nesta tese, de coletivização de demandas individuais.

A sistemática de julgamento de recursos com repercussão geral, de modo que uma única decisão possa abranger todo um universo recursal, é utilizada apenas em sede de recurso extraordinário, pelo STF, sendo operacionalizada pelas instâncias inferiores.

Desse modo, além de se obter a ampliação da eficácia subjetiva do julgado apenas no final das etapas recursais, essa ampliação novamente se dará apenas com relação às questões constitucionais, que poderão ser objeto de recurso extraordinário e, portanto, julgadas com a técnica de julgamento própria da repercussão geral.

\footnotetext{
${ }^{156}$ José Rogério Cruz e TUCCI. "Anotações sobre a repercussão geral como pressuposto de admissibilidade do recurso extraordinário (Lei 11.418/2006)." Revista de Processo,p. 160.

${ }^{157}$ Ibid., p. 159.
} 
Dessa maneira, percebe-se que a repercussão geral atua numa seara diferente daquela onde atua a proposta de coletivização de demandas individuais, pois esta é muito mais abrangente, envolvendo questões de todas as espécies, não apenas constitucionais, e pode ser manejada pela primeira instância, mostrando-se muito mais acessível.

Consolidando a tendência de objetivação dos julgados oriundos dos Tribunais Superiores,a sistemática de julgamento dos recursos especiais repetitivosveio permitir que os Tribunais de Justiça e o próprio STJ suspendam o tramite de recursos especiais, quando diagnosticada existência de uma multiplicidade desses recursos sobre uma mesma questão de direito ${ }^{158}$.

Essa técnica possui algumas diferenças em relação à sistemática da repercussão geral, onde ocorrem dois julgamentos vinculativos, que deverão ser observados pelo tribunal a quo, um preliminar, sobre a existência do requisito de admissibilidade específico da repercussão geral e outro, relativo ao mérito, o que faz com que a doutrina designe a questão constitucional apta a se tornar objeto de um recurso extraordinário como sendo qualificada, diferentemente da questão infraconstitucional, que prescinde de tal qualificação ${ }^{159}$.

Nada obstante, os procedimentos são similares, de modo que tanto por ordem do Presidente doTribunal a quo como por ordem do Tribunal Superior haverá a suspensão dos recursos, especial ou extraordinário, que versarem sobre a mesma questão jurídica, sendo selecionados alguns capazes de representar a controvérsia, com a diferença que, no caso dos recursos extraordinários, antes de analisada a própria questão de direito, será analisada a existência da repercussão geral sobre a questão.

O importante é destacar, que a sistemática dos recursos especiais repetitivos também propicia à atividade jurisdicional uma ferramenta de objetivação da sua atuação, na medida em que autoriza os Tribunais de Justiça a negarem seguimento aos recursos especiais contrários à tese firmada pelo STJ, ou a se retratarem de suas decisões, caso seu acórdão esteja em confronto com a orientação do $\mathrm{STJ}^{160}$.

\footnotetext{
${ }^{158}$ Athos Gusmão CARNEIRO. "Primeiras observações sobre a lei dos recursos repetitivos no STJ." Revista de Processo, p. 84.

${ }^{159}$ José Miguel Garcia MEDINA. "Sobre o novo artigo 543-C do CPC: sobrestamento de recursos especiais ‘com fundamento em idêntica questão de direito.” Revista de Processo,p. 216-217.

${ }^{160}$ Luiz Rodrigues WAMBIER; Rita de Cássia Corrêa de VASCONCELOS. "Sobre a repercussão geral e os recursos especiais repetitivos, e seus reflexos nos processos coletivos.” Revista dos Tribunais,p. 35.
} 
Não obstante a liberdade conferida expressamente aos Tribunais entende-se que,ainda assim, a técnica dos recursos repetitivos propicia a objetivação da atuação do STJ, na medida em que se espera que, os Tribunais sigam a orientação superior, por uma questão de racionalidade e economia processual.

Por esse rumo, o exemplo ajuda a robustecer a ideia em torno da qual orbita o presente tópico, que é a de que existe uma tendência de objetivação da atuação jurisdicional, que pode ser notada na legislação pátria, principalmente com relação à atividade dos Tribunais Superiores, mas que, pelos argumentos dos seus defensores, pode ser estender para a atuação da primeira instância, na medida em que estão consagrados em lei, mecanismos de mitigação dos riscos representados por essa mudança.

Se a objetivação é boa, produz racionalização, economia e uniformidade, por que não nos utilizarmos dela em relação às sentenças judiciais? Por que é preciso milhões de decisões de primeira instância sobre uma mesma questão fática ou jurídica? Será que eventuais benefícios de tal fragmentação superam os prejuízos de uma Justiça abarrotada de processos repetitivos, com decisões completamente dispares sobre o mesmo assunto?

Nesse ponto, pode-se concluir que a tendência de objetivação da atuação dos Tribunais Superiores deve ser estendida para a atuação em primeira instância, servindo os argumentos favoráveis a essa tendência, à justificaçãoda proposta contida no presente trabalho, de coletivização de demandas individuais, que no fim das contas, também almejaoferecer maior objetividade à atuação jurisdicional, com umaampliação subjetiva dos seus resultados, a fim de se obter um maior nível de economia e celeridade processual, sem contar uma maior isonomia.

\subsection{A proposta contida no projeto do novo CPC: incidente de resolução de demandas repetitivas}

Segundo proposta contida no projeto do novo Código de Processo Civil, será admitido o incidente de demandas repetitivas quando identificada questão jurídica com 
potencial de gerar multiplicação de processos similares e decisões judiciais antagônicas ${ }^{161}$, ameaçando a isonomia e a segurança jurídica, conforme o texto emprestado pela alteração promovida na Câmara dos Deputados Federais ${ }^{162}$.

Como se vê, o pressuposto para que se admita tal incidente é o potencial surgimento de demandas judiciais que contenham a mesma questão jurídica, estando afastado o seu uso, portanto, para se dirimir e uniformizar o julgamento de questões fáticas, sendo este, o primeiro ponto que distancia o instituto em análise, do processo coletivo, e reduz o seu campo de abrangência e eficácia em relação a este.

Como é cediço, numa demanda coletiva até as questões fáticas serão decididas uniformemente e beneficiarão a todos os substituídos; no caso do incidente em apreço, ainda que haja alguma questão fática envolvida no litigio, apenas os seus aspectos jurídicos poderão ser objeto de apreciação no incidente ${ }^{163}$.

Esse incidente, em verdade, reproduz uma técnica utilizada na Alemanha para demandas objetivando a tutela de investidores de valores mobiliários, denominada de Musterverfahren, ou técnica do procedimento modelo, por meio da qual, processos repetitivos, que tenham sido objeto de aplicação dessa técnica, são remetidos ao Tribunal pelo juiz de piso, para que seja proferida uma decisão sobre fatos e direitos, que só afetará aqueles processos que já estejam pendentes quando da decisão ${ }^{164}$.

Nada obstante, percebe-se uma dupla finalidade no incidente em questão, que também é perseguida pelo processo coletivo, qual seja: a) evitar a massificação de demandas; b) uniformizar a atuação jurisdicional.

No que tange a capacidade de proporcionar o segundo objetivo, de uniformização da tutela jurisdicional sobre a questão, parece-nos que o incidente será mais eficaz que o processo coletivo, na medida em que ele vinculará a todospro et contra ${ }^{165}$, não havendo a

\footnotetext{
${ }^{161}$ Leonardo Carneiro da CUNHA. "Anotações sobre o incidente de resolução de demandas repetitivas previsto no projeto do novo Código de Processo Civil.” Revista de Processo, p. 261.

${ }^{162}$ Disponível em: http://legis.senado.leg.br/mateweb/arquivos/mate-pdf/151972.pdf, p. 486.

${ }^{163}$ José Maria TESHEINER. "Do incidente de resolução de demandas repetitivas no anteprojeto de código de processo civil (artigos 895 a 906).” Revista Jurídica, p. 27.

${ }^{164}$ Daniele VIAFORE. "As semelhanças e as diferenças entre o procedimento-modelo alemão Musterverfahren e a proposta de um 'incidente de resolução de demandas repetitivas' no PL 8.046/2010." Revista de Processo.p. 277-278.

${ }^{165}$ Guilherme Rizzo AMARAL. "Efetividade, segurança, massificação e a proposta de um "incidente de resolução de demandas repetitivas.” Revista de Processo, p. 265.
} 
chance de decisões divergirem da tese jurídica ali fixada, como há no caso da coisa julgada secundumeventum litis do processo coletivo envolvendo direitos individuais homogêneos.

Todavia, acreditamos também no poder persuasivo de uma sentença coletiva de improcedência, mormente quando ratificada pelos Tribunais pátrios, de modo que é impossível se mensurar, no atual cenário, a distância existente entre as duas técnicas, no alcance do objetivo em comum.

No que tange ao objetivo de evitar a massificação de demandas, parece-nos que ambos tenham um grau de eficácia ainda mais parecido. O processo coletivo pode evitar o ajuizamento de inúmeras demandas, principalmente quando há uma sentença de procedência, já o incidente, quando houver uma decisão de improcedência.

Em verdade, o processo coletivo torna prescindível o ajuizamento de ações individuais, quando a sentença coletiva envolver pedido de declaração, anulação ou condenação a um fazer ou não fazer, por exemplo.

Eventualmente, até uma condenação a pagamento pode não exigir liquidação e execução individual, se existir uma relação continuativa entre o réu e os substituídos, como se verá mais a frente, quando falarmos da coletivização envolvendo direitos individuais homogêneos.

Já o incidente de demandas repetitivas, pelo contrário, pressupõe a propositura de mais ações, para que a tese jurídica possa ser aplicada ${ }^{166}$. Caso não seja proposta a demanda individual, a tese jurídica firmada pelo Tribunal não aproveitará automaticamente àquele individuo.

Nesse sentido, se o Tribunal fixa o precedente em um incidente desses, no sentido de ser nula uma determinada clausula contida num contrato de adesão, todos os consumidores terão de entrar com idêntica demanda para obter tal reconhecimento e afastar a aplicação da clausula inquinada.

Em se tratando de uma sentença de natureza coletiva, uma única sentença já seria suficiente para beneficiar a todos os indivíduos substituídos, inclusive determinando a

\footnotetext{
${ }^{166}$ Ibid., p. 261. Nesse sentido, ensina o autor que: “[...]: a decisão proferida no incidente, embora vincule todo e qualquer futuro julgamento a ser proferido acerca da matéria em discussão, não tem o condão de evitar o ajuizamento de novas ações. Muito pelo contrário: exige-se a instauração de processo judicial individual para que se possa aplicar a tese jurídica (art. 930)."
} 
interrupção de cobrança abusiva baseada na clausula declarada nula, sendo completamente desnecessário o ajuizamento de demandas individuais.

Em contrapartida, parcela da doutrina aponta que o processo coletivo falha na sua missão de impedir a litigiosidade em massa, quando não autoriza a coisa julgada desfavorável ao indivíduo ${ }^{167}$, permitindo que mesmo após uma sentença de improcedência coletiva, milhares de demandas individuais se instaurem.

Tal efeito não ocorreria no caso dos incidentes de demandas repetitivas, uma vez que nestes, fixada a tese jurídica que beneficie ou não a massa de indivíduos que se encontram em posições similares (consumidores, por exemplo), ela será aplicada para todo mundo de maneira vinculante ${ }^{168}$.

Nada obstante, não nos parece que tal argumento seja de todo procedente, pois, insista-se, ele ignora o efeito persuasivo da decisão coletiva, tanto com relação aos indivíduos como em relação aos outros órgãos jurisdicionais.

Parece-nos, que dificilmente haverá uma enxurrada de demandas individuais, se uma pretensão é julgada improcedente coletivamente, principalmente quando esta decisão vem a ser ratificada pelos Tribunais.

Claro que haverá demandas individuais de pessoas que queiram insistir em suas pretensões individuais, mas não ao ponto de representar a ineficácia do processo coletivo contra a litigiosidade em massa.

Com base nisso, aparentemente o processo coletivo ainda se mostra mais eficaz contra a litigiosidade de massa, na medida em que torna desnecessárias demandas individuais em inúmeras hipóteses de procedência dos pedidos, ao contrário do incidente em foco, que pressupõe demandas individuais.

De todo modo, muito interessante se mostra a proposta doutrinária de conciliar as duas técnicas, de modo que o incidente se transforme numa verdadeira coletivização da

\footnotetext{
${ }^{167}$ Ibid., p. 253-254.

${ }^{168}$ Aluisio Gonçalves de Castro MENDES. Roberto de Aragão Ribeiro RODRIGUES. "Reflexões sobre o incidente de resolução de demandas repetitivas previsto no Projeto de novo Código de Processo Civil." Revista de Processo. p. 198. No mesmo sentido: Eduardo Henrique de Oliveira YOSHIKAWA. "O incidente de resolução de demandas repetitivas no Novo Código de Processo Civil: comentários aos arts. 930 a 941 do PL 8.046/2010.”Revista de Processo, p. 263.
} 
demanda individual, com o seu julgamento pelo Tribunal com eficácia pro et contra, desde que oportunizado o opt-out $^{169}$.

Nessa medida, se conseguiria o efeito de se uniformizar de maneira eficaz a decisão sobre determinadas questões, que não seriam reduzidas àquelas de índole jurídica somente, abrangendo também as fáticas, tanto para beneficiar como para prejudicar os indivíduos que não se excluíram do julgamento.

Outrossim, se tornaria desnecessário o ajuizamento de inúmeras ações individuais para aplicação do precedente, vez que a extensão subjetiva da sentença coletiva resolveria o problema para todos, a não ser os casos em que se mostrasse necessária a liquidação e a execução individual, casos estes que podem ser ainda mais diminutos, se observadas algumas anotações realizadas no presente estudo, quando do debate acerca da coletivização de demanda individual versando sobre direito individual homogêneo.

A eficácia pro et contra teria utilidade de evitar o risco de litigiosidade de massa, assim como a eficácia para o futuro do precedente que será construído ${ }^{170}$.

Parece-nos assim, que ambos os institutos possuem vantagens e desvantagens, a ponto de tornar mais segura uma conclusão que preze pela atuação complementar de ambas as técnicas, sem exclusão recíproca, do que uma conclusão que opine por ser melhor uma técnica ou outra.

Na verdade, essa atuação complementar será plenamente factível, na medida em que demandas coletivas poderão ser objetos do incidente de resolução de demandas repetitivas; em tais hipóteses haveria uma união do processo coletivo com a técnica dos precedentes, de modo a proporcionar as vantagens e os riscos de ambas as técnicas.

Acrescenta-se ao que foi dito, importante modificação sofrida no projeto do novo Código construído na Câmara, por meio da qual o incidente só poderá ser suscitado "na pendência de qualquer causa de competência do tribunal"171, dando-nos a entender que só em processos que estiverem aguardando o julgamento de recurso, que poderá ser suscitado tal incidente.

\footnotetext{
${ }^{169}$ AMARAL, op. cit. p. 268, nota 165.

${ }^{170}$ YOSHIKAWA, op. cit. p. 263, nota 168.

${ }^{171}$ Disponível em: http://legis.senado.leg.br/mateweb/arquivos/mate-pdf/151972.pdf, p. 486. Acesso em: 27 de junho de 2014 .
} 
Se essa for efetivamente a intenção a Câmara parece que as diferenças dessa técnica em relação a ora proposta se agravam, conduzindo-nos a conclusão de que a nossa proposta é bem mais abrangente, pois disponibiliza a técnica de coletivização para o juiz de primeiro grau, que se encontra em condições de realizar tal ação com mais antecedência, já que, para que haja recurso, necessário haver decisão judicial prévia.

Assim, a proposta formulada pela Câmara restringe ainda mais o uso do incidente de resolução de demandas repetitivas, tornando-o menos abrangente e, consequentemente, menos apto ao alcance dos objetivos ansiados com a técnica de coletivização de demanda individual, quais sejam: mais celeridade e segurança jurídica para os casos de direitos indivisíveis ou individuais homogêneos.

Conclui-se,de todo modo, em reforço ao que vem sendo dito, pela existência de uma tendência de objetivação da atuação jurisdicional, que demonstra a convergência da proposta contida neste trabalho com as alterações legislativas, tradutoras, ao menos em tese, dos anseios e clamores sociais.

\subsection{A extensão dos efeitos de decisões relativas a direitos sociais constitucionais, proposta por CARLOS ALBERTO SALLES}

O autorCARLOS ALBERTO SALLESapresentou em um artigo, uma tese que em alguma medida se aproxima do que temos falado até então, mas com um espectro de abrangência menor, por se restringir a hipóteses de ações individuais que versem sobre direitos sociais constitucionais ${ }^{172}$.

Segundo o referido autor, o sistema constitucional pátrio já nos daria embasamento suficiente para, com base na isonomia e na impessoalidade que norteia os atos da

Administração Pública, superar os contornos individualistas dos limites subjetivos da coisa julgada, e estender in utilibus os seus efeitos, quando estes concernirem a prestações sociais que devam ser cumpridas pelo Estado ${ }^{173}$.

\footnotetext{
${ }^{172}$ Carlos Alberto SALLES. "Coisa julgada e extensão dos efeitos da sentença em matéria de direitos sociais constitucionais." In: Petronio CALMON; Mirna CIANCI; et al (Coord.).Em defesa de um novo sistema de processos coletivos: estudo em homenagem a Ada Pellegrini Grinover, p. 146-150.

${ }^{173}$ Ibid., p. 148-149. Segundo o autor: "Em primeiro lugar, o problema colocado pode encontrar resposta na interpretação da própria Constituição Federal, sendo possível - e correto - afirmar uma diversa extensão da
} 
Curioso destacar, que não se fala aqui, em problemas ligados a questão da legitimidade e competência, partindo-se da premissa, portanto, que tal proposta não encontra óbice nessas questões, ou seja, o individuo continuará como parte, com a intervenção do parquet e o processamento do feito na primeira instância originariamente.

Outrossim, os efeitos da decisão serão estendidos in utilibus, não havendo risco de prejuízo a qualquer terceiro que não tenha participado do contraditório, que só se beneficiará dessa técnica e mais, caso tenha desrespeitada a decisão por parte do Estado, apenas demonstrará sua situação em juízo e pedirá a satisfação da obrigação estatal, como um liquidação e execução de sentença genérica coletiva.

Para ilustrar a proposta, o autor trabalha com a técnica de ampliação do objeto e extensão in utilibusjá utilizada no processo penal e também no processo coletivo envolvendo direitos indivisíveis ${ }^{174}$.

Além disso, exemplifica a problemática que pode ser criada na atual sistemática, em que não ocorre essa extensão, citando o exemplo do serviço de transporte especial para pessoas com deficiência, afirmando que em face dos contornos individuais das demandas, outras pessoas em situação similar só terão o direito atendido caso ingressem com demanda similar, ou terão de esperar por uma ação coletiva, correndo ainda o risco de decisões divergentes ${ }^{175}$.

A simbioseentre a tese em questão é significativa em relação à tese elaborada neste trabalho, principalmente com relação aos fundamentos, pois a ideia de coletivização das demandas individuais tem espeque, também, na questão ligada à isonomia da proteção dos direitos, que não deve se restringir as hipóteses de direitos sociais constitucionais.

Afinal de contas, porque se admitir que uma decisão que reconheça um direito social constitucional seja transportada in utilibus, para beneficiar a terceiros na mesma situação, e a decisão que reconheça outro tipo de direito, também homogêneo, não o seja?

Seriam os direito sociais constitucionais mais importantes hierarquicamente, a ponto de justificar tal discriminação? Mas os direitos do consumidor ou de um meio ambiente saudável também não possuem status constitucional?

coisa julgada quanto (sic) relacionada a direito constitucionais e, mais exatamente, a direitos sociais consistentes em uma dada prestação pelo Estado ao sujeito de direito."

${ }^{174}$ Ibid., p. 145 e 153.

${ }^{175}$ Ibid., p. 147-150. 
Ao que parece, a possibilidade de transporte in utilibus deve se lastrear na indivisibilidade ou na homogeneidade do direito, e não na sua natureza social constitucional, pois tal particularidade não justificaria tal restrição.

Também os direitos que não são sociais constitucionais merecem ser protegidos com o máximo de eficiência, isonomia e racionalidade, tanto para tornar desnecessária a ida ao Judiciário de inúmeras pessoas, como simplesmente para evitar injustiças, ou seja, evitar que alguns consumidores tenham seus contratos revisados e outros não, ou que alguns trabalhadores recebam determinada vantagem e outros não, ou que algumas vítimas do comportamento do réu sejam indenizadas e outras não.

Se a natureza do direito permite o tratamento molecularizado, pelo fato dele ser indivisível ou homogêneo, proporcionando respostas uniformes com infinita econômica processual, ou seja, com muito mais segurança e celeridade, porque refutar tais benefícios, ou restringi-los a direito sociais?

As técnicas que propiciam a satisfação num maior grau, dos valores que orientam a atividade jurisdicional, devem ser observadas, a não ser que representem sacrifícios desproporcionais de outros valores igualmente importantes.

Conclui-se, portanto, que os fundamentos construídos por Salles, para justificar o transporte in utilibus da sentença sobre direitos sociais, em verdade, se espraiam e alicerçam também a tese de coletivização de demandas individuais, quando envolvendo direitos indivisíveis ou individuais homogêneos, pela mesma razão de prestigio à isonomia e mais, para racionalizar a atividade jurisdicional, evitando o desperdício de tempo e energia.

\section{A UTILIDADE DA COLETIVIZAÇÃO NA BUSCA POR CELERIDADE E EFETIVIDADE}

\subsection{A utilidade nos casos de direitos individuais homogêneos canalizados por milhões de ações repetitivas}


Diante do cenário narrado acima, de total congestionamento da atividade jurisdicional, demandada na maioria dos casos por causa de litigantes habituais, que possuem relações jurídicas homogêneas, como bancos, setor público e empresas de telefonia, o processo coletivo apresenta-se como uma possibilidade de redução do trabalho e do tempo despendido com essas demandas, podendo proporcionar economia e celeridade à atuação jurisdicional.

Nessa medida, a potencialização do uso do processo coletivo, obtida por meio da coletivização judicial de oficio de demandas individuais, pode se apresentar como uma medida salutar para o alcance do objetivo comum de proporcionar ao cidadão uma justiça mais célere e ágil, adequada aos tempos modernos, em que tudo acontece e se modifica rapidamente e num grande volume, devido à facilidade de acesso a informação e à massificação do acesso aos bens de consumo.

Se pensarmos que hoje são mais de noventa milhões de processos em tramite, e que os bancos, por exemplo, respondem por aproximadamente trinta por cento disso ${ }^{176}$, ou seja, trinta milhões de processos, poderemos ter uma noção de como são importantes instrumentos que tutelem de modo coletivo, direitos individuais homogêneos, ou seja, direitos com origem comum, seja ela fática ou jurídica ${ }^{177}$.

No cenário atual mostra-se imperioso o uso de instrumentos hodiernos, condizentes com a velocidade e a massificação dos tempos modernos, em que um único ato atinge a milhões de pessoas.

Também a jurisdição precisa, nos tempos atuais, por meio de um ato, em um processo, poder atingir a milhares de pessoas, para realizar a proteção do direito delas, já que racionalmente não se explica que todas elas venham discutir a mesma coisa e que, por tanto, a jurisdição tenha que repetir a mesma atividade milhares de vezes, com risco de julgamentos conflitantes.

O processo coletivo é uma exigência de racionalidade, numa era em que o mínimo trabalho e o máximo resultado se mostram fundamentais em todos os seguimentos da sociedade.

\footnotetext{
${ }^{176}$ Ver o capítulo 2.

${ }^{177}$ Teori Albino ZAVASCKI. "Reforma do processo coletivo: indispensabilidade de disciplina diferenciada para direitos individuais homogêneos e para direitos transindividuais." In: Ada Pellegrini GRINOVER; Aluisio Gonçalves de Castro MENDES; KazuoWATANABE(Coord.). Direito processual coletivo e o anteprojeto de Código Brasileiro de Processos Coletivos, p. 35.
} 
Dessa maneira, ao invés de milhões de processos discutindo o percentual de juros ou as cláusulas penais praticadas num modelo de contrato de adesão, se poderá com um único processo reconhecer a nulidade de todas as clausulas existentes em contratos concretos, condenar os bancos a se absterem de incluir tal cláusula, bem como a devolverem o valor recebido indevidamente.

O que dependeria de milhões de processos onde seriam discutidas as mesmas questões, será feito num único processo, beneficiando toda a coletividade e o próprio Judiciário, que terá mais tempo para se dedicar ao que realmente precise de uma atuação individualizada.

Conclui-se assim, que o processo coletivo, com a molecularização de demandas individuais,é um importante meio de redução do congestionamento processual atualmente existente, de modo que a coletivização dessas demandas individuais será importante na medida em que aumentará o uso da tutela coletiva.

Com o poder judicial de converter uma demanda individual em coletiva quando presentes os pressupostos, inúmeros casos em que não se tem uma atuação dos entes expressamente legitimados pelo CDC ou pela LACP, serão objeto de atuação numa dimensão coletivizada, com economia de esforços pela molecularização da atuação.

A coletivização judicial de demandas individuais representa a possibilidade de o Judiciário dizer, qual proporção terá a atuação a ser desempenhada em uma demanda,mas isso só será feito, naturalmente, após a análise dos pressupostos autorizadores a tanto, tais como a necessidade de se coletivizar e a homogeneidade das questões ${ }^{178}$.

A prova da eficácia da coletivização judicial de demandas para a redução do número de processos pode ser absorvida pela experiência vivenciada no STF, que após a criação da técnica da repercussão geral, por meio da qual também se coletiviza a atuação jurisdicional para a resolução de uma questão jurídica, com algumas nuances, é óbvio, teve uma redução drástica no número de processos aguardando julgamento ${ }^{179}$.

\footnotetext{
${ }^{178}$ Charles DONELAN. "Prerequisites to a Class Action Under New Rule 23." 10 B.C.L. Rev., p. 529-532, Disponível em: http: //lawdigitalcommons.bc.edu/bclr/vol10/iss3/6.

${ }^{179}$ BRASIL. Supremo tribunal federal. Estatísticas do STF: movimento processual. Brasília 2010. Disponível em: http://www.stf.jus.br/portal/cms/verTexto.asp?servico=estatistica\&pagina=movimentoProcessual. No mesmo sentido: Natalia Martins PIMENTA. Coletivização das demanda individuais: as técnicas processuais de julgamento das demandas individuais à luz do princípio do contraditório,p. 49-50.
} 
Perceba que, por meio da técnica da repercussão geral, apesar de não se ter uma coletivização de uma demanda individual, tem-se a coletivização da atuação jurisdicional, efeito que também se pretende com a técnica ora proposta, de modo que uma única decisão atinge a milhares de pessoas, tornando desnecessária a rediscussão infinita da mesma questão nos moldes individuais.

Deve-se registrar ainda, que a redução dos processos repetitivos, pela coletivização de demanda individual, beneficiará não só os titulares de direitos individuais homogêneos, mas todos que dependem da atuação jurisdicional, que poderão contar com um serviço mais dinâmico e menos sobrecarregado.

Não bastassem essas colocações voltadas à redução do número de demandas e do tempo para resolvê-las, insta frisar ainda que, na medida em que se tem uma ampliação do uso da tutela coletiva, tem-se de maneira mais eficaz a proteção de interesses que não seriam tutelados na via individual, pela inviabilidade econômica que isto representaria ${ }^{180}$.

Assim, bastará uma demanda individual cobrando um valor que para muitos não justificaria um litigio, para que o judiciário converta tal procedimento em um processo coletivo, beneficiando todos aqueles que despenderam tal quantia e impedindo o enriquecimento ilícito do réu; sem duvida, a coletivização torna mais fácil e prática a tutela desses direitos.

Outra observação importante, é que a ampliação do uso da tutela coletiva, por meio da coletivização de demandas individuais, poderá proporcionar a tutela de direitos pertencentes a pessoas vulneráveis, de poucas condições econômicas ou culturais, para a instauração e manutenção de um litigio contra uma grande empresa, fornecedora de um produto ou serviço ${ }^{181}$.

Nesse sentido, a partir de uma única demanda em que se constate a existência de direitos individuais homogêneos relacionados, o judiciário poderá coletivizar a sua atuação, para beneficiar pessoas que, muitas vezes, jamais reivindicariam a tutela dos seus direitos, por pertencerem a uma camada da sociedade que não tem acesso a todas as informações necessárias ou, tendo acesso, não tem dinheiro para contratar um advogado e

\footnotetext{
${ }^{180}$ Janet Cooper ALEXANDER."An introduction to Class Actions Procedure in the United States".Disponível em:http://law.duke.edu/grouplit/papers/classactionalexander.pdf, p. 1.

${ }^{181}$ José Carlos BARBOSA MOREIRA. “A efetividade do processo de conhecimento.” Revista de Processo, p. 136.
} 
sustentar um litigio, não podendo também contar com a defensoria, pois muitas vezes recebe acima do teto legalmente estipulado.

Por fim, não custa lembrar o benefício que o processo coletivo proporciona a isonomia, constitucionalmente preconizada como um direito fundamental, pois pelo modelo tradicional e individualista de resolução de conflitos, um mesmo grupo de indivíduos conterá membros que terão seu direito tutelado e outros que não, mesmo sendo homogêneos.

Isto se dá, porque uma decisão judicial não vincula a outra a ser proferida em outro caso individual, mesmo que o direito seja homogêneo, contudo, no processo coletivo fatalmente uma decisão favorável irá igualmente beneficiar a todos os indivíduos membros do grupo.

Desse modo, é reduzida a chance de membros do grupo, ficarem sem a tutela dos seus direitos enquanto outros a obtém, ou seja, é reduzida a chance do judiciário agir de maneira não isonômica.

O processo coletivo tem entre suas funções, justamente, equilibrar as desigualdades, e um dos meios,épelo prestígio a isonomia, decorrente do fato de todo o grupo ser beneficiado pela decisão coletiva.

Destarte, conclui-se que a coletivização judicial de demandas individuais poderá gerar muitos efeitos positivos para a sociedade e à atividade jurisdicional, na medida em que proporcione uma ampla redução no número de processos repetitivos, com uma ampliação do acesso à justiça para a tutela de direitos economicamente inviáveis ou para beneficiar grupos de vulneráveis culturais ou econômicos, e ainda proporcionando mais isonomia na atuação jurisdicional, com a proteção integral dos grupos de pessoas, nos casos em que isto se mostrar conforme o direito.

\subsection{A utilidade nos casos de direitos indivisíveis}

Antes de tudo é preciso esclarecer, que a admissão de demandas individuais versando sobre direitos indivisíveis não é compartilhada por todos os setores da 
doutrina $^{182}$, mas entendemos ser indispensável tal possibilidade, como um corolário do direito fundamental de acesso à justiça ${ }^{183}$, que, aliás, possui inúmeros exemplos ilustrados na lei infraconstitucional, onde o legislador autorizou expressamente o individuo, a demandar em nome de um grupo, sem que sua atuação prejudicasse aqueles que não

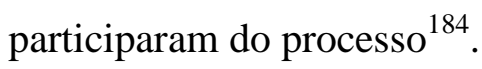

Fixada tal premissa, deve-se salientar que, em se tratando de direitos indivisíveis, a importância do poder judicial de coletivização de demandas individuais se espraia por outras questões que vão além da preocupação com a quantidade de demandas repetitivas, o que ainda assim é um fator significativo, se pensarmos em milhares de ações individuais que são propostas visando à intervenção judicial em concursos e até em politicas publicas, ou mesmo em deliberações tomadas por sociedades anônimas compostas por inúmeros acionistas.

Ainda que nesses casos entendamos que a coisa julgada em um afetará todos os demais, especialmente nos casos em que não for viável a aplicação da regra coisa julgada secundumeventum litis, como nos casos de anulação de assembleia de sociedades anônimas ou de questões de concursos públicos, já que haverá sempre dois grupos antagônicos que não podem ser tratados de maneira não isonômica, ainda nestes casos, costumaocorrera repetição de demandas individuais em grande número, o que além de congestionar o judiciário, provoca conflitos práticos entre coisas julgadas antagônicas ${ }^{185}$, podendo ser evitado com um instrumento que potencialize a utilização do processo coletivo ${ }^{186}$.

\footnotetext{
${ }^{182}$ Kazuo WATANABE. Relação entre demanda coletiva e demandas individuais. In: Ada Pellegrini GRINOVER; Aluisio Gonçalves de Castro MENDES;Kazuo WATANABE (Coord.). Direito Processual Coletivo e o anteprojeto de Código Brasileiro de Processos Coletivos, p. 160.

${ }^{183}$ Aluisio Gonçalves de Castro MENDES; Larissa CLare Pochmann da SILVA. "A legitimidade ativa do individuo nas ações coletivas." Revista de Processo,p. 43. No mesmo sentido: Aluisio Gonçalves de Castro MENDES. "A legitimação, representatividade adequada e a certificação nos processos coletivos e as ações coletivas passivas." Revista de Processo,p. 254.

${ }^{184}$ José Carlos BARBOSA MOREIRA. Litisconsórcio unitário.p. 131. Marcelo José Magalhães BONICIO; Heitor Vitor Mendonça SICA."Ensaio sobre os aspectos materiais e processuais do litisconsórcio unitário." In: Aluisio Gonçalves de Castro MENEDES; Teresa Arruda Alvim WAMBIER. O processo em perspectiva: jornadas brasileiras de direito processual, p. 280. HumbertoTHEODORO JÚNIOR. Curso de Direito Processual Civil: teoria geral do direito processual civil e processo de conhecimento, p. 116. FredieDIDIER JÚNIOR. Curso de Direito Processual Civil: teoria geral do processo e processo de conhecimento, p. 323.

${ }^{185}$ José Carlos BARBOSA MOREIRA.Litisconsórcio unitário,p. 143-144. Marcelo José Magalhães BONICIO; Heitor Vitor Mendonça SICA. "Ensaio sobre os aspectos materiais e processuais do litisconsórcio unitário." In: Aluisio Gonçalves de Castro MENEDES; Teresa Arruda Alvim WAMBIER. O processo em perspectiva: jornadas brasileiras de direito processual, p. 300.

${ }^{186}$ Aluisio Gonçalves de Castro MENDES. "A legitimação, representatividade adequada e a certificação nos processos coletivos e as ações coletivas passivas." Revista de Processo, p. 255.
} 
Nesses casos, verificado o ajuizamento de uma ação individual visando à anulação de uma questão de concurso ou uma deliberação de uma grande sociedade anônima, o juiz converteria o processo individual em coletivo, prevenindo um possível e caótico conflito prático entre coisas julgadas antagônicas sobre objeto indivisível, bem como tornando desnecessário o ajuizamento de milhares de ações individuais ${ }^{187}$, cabendo ao indivíduo a alternativa de tentar auxiliar na condução do processo coletivo.

Percebe-se de plano, então, uma dupla utilidade do poder judicial de coletivização de demandas individuais nos casos de direitos indivisíveis, quais sejam: redução do numero de demandas aliada a eliminação do risco de conflitos práticos entre coisas julgadas individuais antagônicas.

Esse último aspecto é irrelevante no caso de direito individuais homogêneos, porque lá, sendo divisível o direito, a coisa julgada individual ou mesmo coletiva nunca prejudicará o individuo que não participou do processo coletivo.

Contudo, no caso de direitos indivisíveis, caso sejam objetos de demandas individuais, costumeiramente a coisa julgada trará reflexos práticos em outras demandas com o mesmo objeto indivisível, pois não tem como se anular a questão de um concurso apenas para um candidato, muito menos anular a assembleia apenas para um acionista, ou incluir um medicamento no rol daqueles distribuídos gratuitamente pelo estado apenas para um cidadão ${ }^{188}$.

Nesses casos, a decisão que anula impede a decisão que reconheça a validade, de modo que a aplicação da regra da coisa julgada secundumeventum litis não se faz possível, sob pena de afronta a isonomia, já que beneficiaria apenas o grupo de pessoas interessado na anulação, em total detrimento daqueles que preferem a manutenção da questão ou das decisões assembleares ${ }^{189}$.

Em alguns casos, mesmo em se tratando de direitos indivisíveis, a utilização da coisa julgada secundumeventum litis se faz possível, como nos casos de demandas que visam àinterrupção de praticas poluentes por parte de uma empresa, por exemplo, já que não se concebe a existência de um grupo com legitimidade e interesse em pleitear a manutenção da prática.

\footnotetext{
${ }^{187}$ Ibid., p. 255

${ }^{188}$ BONICIO; SICA, op. cit. p. 3 e 18, nota 185.

${ }^{189}$ Ibid., p. 03.
} 
Entretanto, nos casos envolvendo direito potestativo de anulação ou declaração de validade de atos jurídicos o máximo que se consegue e a aplicação de uma coisa julgada secundumeventumprobationis, ou seja, o afastamento da coisa julgada apenas nos casos de sentença de improcedência por falta de provas, pois, insista-se, dizer que a coisa julgada só ocorreria na hipótese de anulação ou declaração de nulidade seria colocar em situação inferior o grupo de pessoas que tem interesse no reconhecimento da validade do ato, e teriam legitimidade para propor uma demanda nesse sentido.

Nessas situações, sendo inviável a aplicação da coisa julgada secundumeventum litis, as demandas individuais que versassem sobre tais objetos, ou afetariam a todos, sendo positiva ou negativa, ou não afetariam a ninguém, representando o fim da coisa julgada material.

Sendo assim, na primeira hipótese a anulação da assembléia ou da questão valeria também para aqueles que não participaram do processo, mas tinham interesse na manutenção das decisões assembleares ou da questão de um concurso, na segunda hipótese a anulação do ato não valeria para terceiros, que poderiam se opor com ações individuais, gerando conflitos práticos intermináveis e insolúveis ${ }^{190}$.

Deve-se salientar, que a alternativa do litisconsórcio necessário nem sempre se mostra viável, tendo em vista o número excessivo de pessoas que podem estar envolvidas na relação jurídica material ${ }^{191}$.

No caso da decisão judicial afetar a todos, teríamos um total desprestigio ao principio do contraditório, enquanto que, no caso de não afetar a ninguém, haveria prejuízo à coisa julgada e ao escopo de pacificação social, pois a todo o momento a demanda poderia ser reproposta.

Nessas situações, parece natural que o processo individual não se mostre adequado ao tipo de conflito ${ }^{192}$, cabendo ao judiciário adequar o modelo de processo instaurado em concreto, às necessidades que o conflito realmente apresenta.

\footnotetext{
${ }^{190}$ Ibid., p. 25. Os autores apresentam uma teoria muito interessante, argumentando que uma forma de se evitar isso, seria pela aplicação da coisa julgada secundumeventum litis apenas nos casos envolvendo relações jurídicas incindíveis, constituída por pessoas indeterminadas e indetermináveis (direitos difusos). Por outro lado, em se tratando de relações jurídicas constituídas por pessoas determinadas ou determináveis (coletivo stricto sensu), haverá a imutabilidade da coisa julgada em favor ou contra aqueles que não participaram do processo.

${ }^{191}$ Falando da numerosidade como requisito para a classaction: Charles DONELAN. "Prerequisites to a Class Action Under New Rule 23."10 B.C.L. Rev., p. 529-530, Disponívelem: http: //lawdigitalcommons.bc.edu/bclr/vol10/iss3/6.
} 
Conclui-se assim, que a importância da coletivização de demandas individuais que versem sobre direito indivisíveis concerne à possibilidade de, por meio do prestígio ao modelo coletivo de processo, se evitar conflitos práticos entre decisões judiciais divergentes sobre direitos indivisíveis, ou ainda, para outra vertente, se evitar a eternização dos conflitos, decorrente da contínua possibilidade de repropositura de demandas envolvendo o mesmo e único direito.

Resta salientar no ensejo, a importância da coletivização em relação a questão da extensão in utilibusdos efeitos da sentença coletiva que verse sobre direitos indivisíveis, o que é reconhecida como uma verdadeira ampliação objetiva da coisa julgada, similar a que ocorre no âmbito penal ${ }^{193}$.

Nesse sentido, o CDC prevê a possibilidade do individuo se valer da sentença coletiva que verse sobre direitos indivisíveis, para liquidar e executar suas pretensões individuais baseada em tais decisões, como, por exemplo, poderia ocorrer com uma sentença que determinasse a interrupção de certa atividade industrial, pela nocividade que tal conduta oferece ao meio ambiente.

Todo e qualquer indivíduo que tenha sofrido danos ambientais por conta dessa conduta judicial interrompida, poderá se valer da sentença para liquidar e executar seus danos, sem mais ter de discutir sobre o potencial ofensivo da conduta da indústria.

Ocorre que, se for admitida uma ação individual sobre direito indivisíveis, a sentença não terá essa mesma utilidade, de modo que cada indivíduo precisará discutir individualmente sobre a nocividade ou não da conduta.

No caso, por exemplo, de acionistas que tenham sido prejudicados pela deliberação de uma sociedade anônima que veio a ser declarada nula, se tal sentença for coletiva, proveniente de uma demanda coletiva, cada acionista poderá liquidar seus prejuízos com base na referida sentença, que reconheceu a ilegalidade da prática adotada com base em deliberação declarada nula, para posteriormente executar.

O que deverá ser comprovado em liquidação será apenas o prejuízo e o nexo causal, mas não será mais discutido se a deliberação que autorizou determinada conduta foi válida

\footnotetext{
${ }^{192}$ Aluisio Gonçalves de Castro MENDES. "A legitimação, representatividade adequada e a certificação nos processos coletivos e as ações coletivas passivas." Revista de Processo, p. 255.

${ }^{193}$ Ada Pellegrini GRINOVER. Coisa julgada erga omnes, secundumeventum litis e secundumprobationem. Revista de Processo,p. 20.
} 
ou não, se a conduta foi lícita ou não, o que encurta o debate, economiza esforços e recursos e propicia um resultado mais célere, que se reflete positivamente sobre todo os sistema.

Nesse mesmo exemplo de anulação de deliberação assemblear, caso isso ocorra por meio de uma sentença individual, a extensão in utilibuspara os indivíduos não ocorrerá, o que corrobora o extenso rol de vantagens que o processo coletivo apresenta em face do individual, mormente nos casos de direitos indivisíveis, e dá musculatura a presente proposta, de coletivização judicial de demandas individuais.

Verificada uma ação individual nesses termos, poderia o juiz então, convertê-la em coletiva, insista-se, observando sempre e criteriosamente a presença de todos os pressupostos e o dever de fundamentação, para que a sentença possa ser aproveitada pelos indivíduos com relação as suas pretensões individuais relacionadas ao direito indivisível objeto de julgamento.

Conclui-se assim, que a vantagem da coletivização judicial de demandas individuais, nos casos envolvendo direitos indivisíveis, vai além da possível redução do numero de processos repetitivos e, consequentemente, de trabalho desnecessário, para oferecer maior segurança e coerência jurídica com relação aos efeitos da coisa julgada, e também o aproveitamento in utilibus pelos indivíduos, que redundará, no fim das contas, na redução do número de processos, ou pelo menos da complexidade dos mesmos.

\section{UMA PERSPECTIVA CONSTITUCIONAL SOBRE O ASSUNTO}

Avançando na construção da proposta objeto deste trabalho, concernente à possibilidade de coletivização de processos individuais por meio de uma decisão judicial, mostra-se imperiosa uma análise de sua compatibilidade com o sistema constitucional, investigando-se a existência de alguma norma que pudesse representar um óbice, ou, pelo contrário, conferir subsídios a ela.

Para tanto, algumas normas constitucionais merecem destaque, pois se referem diretamente a um núcleo mínimo de direitos e garantias fundamentais processuais, inerentes a ideia guia de devido processo legal e processo equo egiusto ${ }^{194}$.

\footnotetext{
${ }^{194}$ Luigi Paolo COMOGLIO. Eticae técnica del “giusto processo”.p. 48-49.
} 
A primeira dessas normas que merece destaque éo direito fundamental de acesso à justiça, materializado especialmente nos incisos XXXIV e XXXV do artigo $5^{\circ}$ da Constituição Federal, que preveem o direito de petição ao Poder Público em caso de violação de direitos e a inafastabilidade da Função Jurisdicional ${ }^{195}$.

Tais normas, ao preverem tais direitos, obviamente não se resumem a garantir um simples serviço de protocolo de petições nos Fóruns da Comarca, mas sim preconizam o direito do individuo e da coletividade terem acesso a uma ordem jurídica justa ${ }^{196}$, com uma tutela jurisdicional efetiva, célere e segura, o que se traduz num acesso substancial ao Judiciário, e não meramente formal ${ }^{197}$.

Tal interpretação é decorrente de uma visão diferenciada e moderna do direito constitucional, que não mais reduz o Estado a um simples garantidor de liberdades, mas o considera também um promotor de justiça social e participação democrática, num modelo conhecido como Estado Democrático de Direito ${ }^{198}$.

Nesse modelo não se pode conceber que as normas constitucionais sejam meramente programáticas, desprovidas de sanção e possibilidade de aplicação coercitiva, pois a importância normativa da constituição e dos valores nela incrustrados mostrou-se fundamental para o alcance de um arquétipo mais justo de Estado e de intervenção estatal $^{199}$.

\footnotetext{
${ }^{195}$ Luciano Picoli GAGNO. Direito fundamental de acesso à justiça e técnicas de otimização da atividade e do juízo probatórios, p. 24-25.

${ }^{196}$ KazuoWATANABE. Acesso à justiça e sociedade moderna. In: Candido Rangel DINAMARCO et al.Participação e processo, p. 128.

${ }^{197}$ José Roberto dos Santos BEDAQUE. Tutela cautelar e tutela antecipada: tutelas sumárias e de urgência. (tentativa de sistematização), p. 73-74. Segundo o autor: "Em razão disso, a inafastabilidade do Poder Judiciário não pode representar garantia formal de exercício da ação. É preciso oferecer condições reais para a utilização desse instrumento, sempre que necessário. De nada adianta assegurar contraditório, ampla defesa, juiz natural e imparcial, se a garantia de acesso ao processo não for efetiva, ou seja, não possibilitar realmente a todos meios suficientes para superar eventuais óbices existentes ao pleno exercício dos direitos em juízo. [...] Essa garantia representa, portanto, o direito de obter do Estado mecanismo eficiente de solução de controvérsias, apto a proporcionar a satisfação efetiva ao titular de um direito, bem como impedir a injusta invasão da esfera jurídica de quem não se acha obrigado a suportá-la."

${ }^{198}$ Bruno GALINDO. Direitos Fundamentais: analise de sua concretização constitucional. Curitiba: Juruá, 2006, p. 67.

${ }^{199}$ Luis Roberto BARROSO. Fundamentos teóricos e filosóficos do novo direito constitucional brasileiro. In: (Coord.). A nova interpretação constitucional: ponderação, ..., p. 26. Segundo o autor: "Sem embargo da resistência filosófica de outros movimentos influentes nas primeiras décadas do século, a decadência do positivismo é emblematicamente associada à derrota do fascismo na Itália e do nazismo na Alemanha. Esses movimentos políticos e militares ascenderam ao poder dentro do quadro de legalidade vigente e promoveram a barbárie em nome da lei. Os principais acusados de Nuremberg invocaram o cumprimento da lei e a obediência a ordens emanadas da autoridade competente. Ao fim da Segunda Guerra
} 
Com a evolução do paradigma liberal para o social surge a noção de direitos a prestações positivas por parte do Estado, que não era mais visto apenas como ente que deveria se abster de intervir para garantir liberdade, emergindo nesse cenário as normas prevendo prestações sociais, carregadas de conteúdo axiológico, naturalmente vago e generalista $^{200}$.

Tais normas, entretanto, justamente pela sua abertura esbarravam no legalismo acrítico e somente a introdução de um paradigma pós-positivista na hermenêutica jurídica, justificado pelas decepções com o positivismo extremado ${ }^{201}$, fez com que os direitos fundamentais sociais e de participação deixassem de representar meras palavras, para terem eficácia supervisionada pelo Judiciário, responsável por limitar os excessos e suprimir a omissões.

No panorama atual, portanto, as normas constitucionais, mesmo as de caráter principiológico, pela sua abertura semântica ou estrutural ${ }^{202}$, possuem eficácia e aplicabilidade plena e imediata, como a própria constituição afirma, de modo que o direito fundamental a prestação jurisdicional efetiva deverá ser promovido pelo Estado, que não poderá apenas se abster de obstruí-lo.

Do contrário, ou seja, se reduzíssemos o papel do Estado frente a este direito, ele estaria indiretamente sendo obstruído, pois a omissão é uma forma disfarçada de se dificultar o acesso à justiça, quando se deixa de criar ou de se utilizar mecanismos mais expeditos no alcance dos objetivos jurisdicionais.

Dessa maneira, se compreendido o direito fundamental de acesso à justiça como um direito fundamental à prestação positiva, no afã de se proporcionar ao jurisdicionado um acesso substancial ao Judiciário, mais célere e seguro, e não simplesmente formal, poderemos concluir que tal norma confere total amparo à proposta do presente trabalho, pois esta visa à concepção de uma técnica processual, com algumas peças normativas já fornecidas pelo nosso ordenamento, capaz, principalmente, de reduzir o tempo de espera pelo acesso a uma justiça efetiva, sem oferecer riscos além daqueles inerentes a toda atividade judicante.

Mundial, a idéia de um ordenamento jurídico indiferente a valores éticos e da lei como estrutura meramente formal, uma embalagem para qualquer produto, já não tinha mais aceitação no pensamento esclarecido."

${ }^{200}$ Robert ALEXY. Teoria dos direitos fundamentais, p. 70-71.

${ }^{201}$ BARROSO, op. cit. p. 26, nota 199.

${ }^{202}$ ALEXY, op. cit. p. 70-71, nota 200. 
O fato da técnica em questão não poder ser extraída da literalidade da norma constitucional parece-nos um problema já superado pela doutrina, mormente aquela que, inspirada na jurisprudência alemã, trabalha com a ideia de normas atribuídas, nos casos em que, encerrando valores ou cláusula gerais (abertura semântica ou estrutural), as normas constitucionais careçam de maior densificação do seu significado ${ }^{203}$.

No caso em tela, quando se garante o direito de petição ou a inafastabilidade da jurisdição - o que pode ser sintetizado no acesso à justiça, se tem uma cláusula geral (abertura estrutural), por não se saber exatamente as consequências da aplicação ou inobservância de tal norma, totalmente desprovida de detalhamentos sobre a sua aplicação, o que faz com que o Judiciário complemente seu enunciado, para lhe atribuir significado num caso concreto.

Foi nessa senda, que a Corte Constitucional argentina, ao interpretar a cláusula constitucional que possibilita a defesa de direitos de "impacto coletivo", entendeu por admitir os indivíduos afetados pelo dano, como legitimados para o processo coletivo, mesmo que não houvesse um procedimento pormenorizado na lei, como ocorreu no caso Halabi, Ernesto v. Poder Executivo, onde se discutia a constitucionalidade da lei que permitia a interceptação telefônica sem autorização judicial préviaa ${ }^{204}$.

Fazendo um paralelo com a Constituição brasileira, podemos comparar a referida norma constitucional, com a nossa que fala sobre a inafastabilidade da tutela jurisdicional, tanto na dimensão individual como coletiva.

Conclui-se assim, que se a coletivização judicial de demandas individuais semostrar efetivamente apta a garantir maior celeridade e segurança, sem, para tanto, se incompatibilizar com o sistema jurídico em outros pontos, forçosa será a sua aplicação, pelo fato do direito não poder se resumir aos enunciados pormenorizadamente expressos em regras legais.

Naturalmente, o ato jurisdicional por meio do qual essa coletivização será promovida deverá observar outros cânones inerentes à ideia de um acesso à justiça substantivo, tais como contraditório, ampla defesa, fundamentação, publicidade e razoável duração.

\footnotetext{
${ }^{203}$ Ibid., p. 70-71.

${ }^{204}$ Aluisio Gonçalves de Castro MENDES; Larissa Clare Pochmann da SILVA. "A legitimidade ativa do individuo nas ações coletiva". Revista de Processo, p. 35.
} 
Desse modo, antes de qualquer decisão deverão as partes se manifestar sobre a possibilidade de coletivização, cabendo à posterior decisão motivar adequadamente a sua conclusão, observando o percurso estabelecido no capítulo quarto, a fim de proporcionar segurança e livre acesso à via recursal.

Alguém poderia suscitar um óbice constitucional à proposta em questão, lastreado na garantia do juiz natural, que veda a criação de tribunais de exceção, ou seja, de instâncias criadas posteriormente à ocorrência de um fato, com o fim de submetê-lo a julgamento $^{205}$.

Entretanto, quando um juiz coletiviza uma ação individual, em nada se assemelha a situação em que o Estado cria um tribunal de exceção, ou seja, um tribunal especifico para o julgamento de uma causa já ocorrida.

O juiz que coletivizar uma demanda individual será um juiz previamente constituído, encontrando-se em exercício em um órgão jurisdicional previamente já constituído também, com competência prevista em lei, anteriormente a propositura da ação, para o conhecimento de demandas individuais ou coletivas similares àquela que coletivizada.

Desse modo, a coletivização judicial de demandas individuais em nada caracterizará a criação de um tribunal de exceção ou violação ao cânone do juiz natural, que, em última analise, se propõe a garantir imparcialidade aos jurisdicionados.

Não bastassem tais fundamentos, importante destacar que, se a utilização do processo coletivo propicia maior celeridade e uniformidade no tratamento das questões, a sua utilização potencializada se mostra em total convergência com os direitos fundamentais à razoável duração do processo e à isonomia, devendo-se recordar que tais preceitos possuem aplicabilidade plena e imediata, de modo a autorizar a sua proteção diretamente pelo Judiciário, mediante uma decisão fundamentada e que respeite o direito ao contraditório e a ampla defesa.

Impende relevar no ensejo, a importância do processo coletivo para a satisfação do direito fundamental a um tratamento isonômico, impedindo assim a prolação de decisões incongruentes sobre fatos similares e muitas vezes sobre objetos indivisíveis, o que traz seríssimos problemas para a legitimação da atividade jurisdicional.

\footnotetext{
${ }^{205}$ Ada Pellegrini GRINOVER. O processo em evolução,p. 58.
} 
Desse modo, o processo coletivo, além de propiciar um isonômico tratamento de todos os direitos individuais homogêneos, ainda propicia o adequado tratamento dos direitos indivisíveis, impedindo a ocorrência de conflitos práticos, inerentes a prodigalização de demandas individuais sobre objetos indivisíveis, que só reduz a segurança jurídica e a legitimidade da intervenção estatal.

Alguma dúvida poderia remanescer, a respeito da compatibilidade da proposta em tela com o direito fundamental de liberdade individual, pois para muitos poderá soar autoritária a ideia de permitir que o próprio Judiciário converta uma ação individual em coletiva, contudo, para se contrapor a tal pensamento cabem pelo menos dois argumentos.

O primeiro consiste no fato da proposta em questão não pressupor a coletivização sem a participação das partes do processo, que deverão ser intimadas para apresentarem eventuais argumentos, baseados na demora que poderia ser causada, a fim de evitar a coletivização, que só será realizada quando não representar prejuízo à parte originária.

O segundo argumento consiste numa adequada interpretação do conceito de liberdade, que não significa permitir que o indivíduo possa fazer tudo que quiser, mas sim aquilo que todos também possam fazer ao mesmo tempo ${ }^{206}$, ou seja, o direito a liberdade pressupõe isonomia, na medida em que eu só tenho liberdade quando me equiparo ao meu semelhante em direitos e obrigações.

Desse modo, para que o individuo seja livre eu não preciso autorizá-lo a fazer tudo e, portanto, não preciso afirmar que caberá exclusivamente a ele a escolha pelo modelo de processo no caso em concreto, quando isto não lhe trouxer qualquer prejuízo na busca pelo seu direito.

A atividade jurisdicional é pública ${ }^{207}$, de modo que caberá a ela, subordinada à lei e à constituição, e com a participação das partes, definir a extensão subjetiva dos efeitos de sua decisão, a fim de proporcionar os melhores resultados possíveis (mais céleres e seguros), salvo quando isto for prejudicial aos interesses individuais em concreto.

Que liberdade seria essa, que autorizaria um individuo recusar a coletivização de sua demanda de maneira meramente caprichosa, ou seja, sem qualquer fundamento jurídico racional para tanto? Isso não se chama liberdade, mas sim alvedrio, que deve ser

\footnotetext{
${ }^{206}$ Fabio Konder COMPARATO. A afirmação histórica dos direito humanos, p. 21.

${ }^{207}$ Candido Rangel DINAMARCO. A Instrumentalidade do Processo, p. 447.
} 
evitado no desempenho de atividades estatais, tanto para se afastar o abuso estatal como o abuso de particulares sobre a máquina pública.

Outrossim, uma técnica processual que ambicione estender a proteção dos direitos ao maior número de pessoas possível, proporcionado uma tutela jurídica mais célere e segura, está mais próxima da ideia de liberdade - pois esta não existirá sem a proteção de direitos, do que da ideia de autoritarismo - pois este nega a existência efetiva de direitos.

Ainda que, baseado numa corrente garantista, se afirme que a atuação jurisdicional deverá ser mínima, a fim de não se consumar um desrespeito às garantias constitucionais $^{208}$, parece-nos incorreta tal perspectiva, na medida em que ela não aponta uma garantia constitucional específica que estaria sendo desrespeitada pela concepção publicista de processo.

Em verdade, os garantistas apenas se limitam a importar do processo penal o discurso de mínima atuação do juiz, o que naquela seara faz todo sentido, já que no direito penal um processo mal instruído beneficia o indivíduo e o seu direito fundamental a liberdade em detrimento da pretensão punitiva estatal, ao contrário do processo civil, em que um processo mal instruído fatalmente prejudicará um dos indivíduos envolvidos, que em sua essência possui o mesmo direito de acesso à ordem jurídica justa que a outra parte.

Percebe-se então, que não há como se falar em violação ao direito fundamental a liberdade, causada pela proposta de coletivização judicial das demandas individuais, a não ser que se distorça o milenar sentido da palavra liberdade e se prefira um juiz inerte, mais suscetível ao erro e a omissão indesejada no exercício da atividade, que deveria promover a tutela dos direitos, normalmente patrimoniais, entre indivíduos iguais.

Dessa maneira, finaliza-se a análise promovida neste capítulo, enveredando-se pelo rumo do devido processo legal, ou do processo equo e giusto, que nada mais é do que uma cláusula geral, que impõe a observância dos direitos e garantias constitucionais processuais, mormente aquelas relacionadas ao direito de defesa, para impedir o uso abusivo do poder estatal ${ }^{209}$.

\footnotetext{
${ }^{208}$ Franco CIPRIANI. El autoritarismo procesal (y laspruebasdocumentales). Revista IusetPraxis, versão online disponível em: www.scielo.cl/scielo.php?pid=S0718-00122007000200003\&script=sci_ar..., p. 4. Ver também: Franco CIPRIANI. "Nelcentenariodelregolamentodi Klein (Il processo civiletralibertà e autorità)."RivistadiDirittoProcessuale, p. 983.

${ }^{209}$ Luigi Paolo COMOGLIO. Eticae técnica del "giusto processo”,p. 49
} 
Com origens no direito anglo saxão, no século XIII, o devido processo legal surgiu como um mandamento visando a obstar o poder ilimitado do Estado, obrigando-o a respeitar os direitos de defesa daqueles que eram processados de alguma forma ${ }^{210}$.

Inicialmente previsto como o dever do soberano observar as leis da terra (lawoftheland) quando fosse processada uma pessoa, esse preceito jamais significou um mandamento de observância estrita da legalidade, mesmo porque, na época e local de sua concepção a noção de direito e legalidade era completamente diferente da que se tem hoje, seja porque o Reino Unido se funda na matriz jurídica do common law, onde os costumes e os precedentes conformam um direito muito mais retórico e casuístico, seja porque na época de sua previsão os ordenamentos jurídicos eram primitivos e, naturalmente, infinitamente mais simples.

Com a evolução das sociedades e do sistema jurídico britânico e norte-americano, o principio do devido processo legal ainda ganhou novos matizes, para significar não apenas uma cláusula de justiça procedimental, que garantia os direitos dos processados participarem e se defenderem no processo, para representar também um mandamento de justiça substancial, que impõe a observância da razoabilidade e proporcionalidade em todos os atos praticados pelo Estado, inclusive aqueles oriundos do legislativo, como já sedimentado pelo STF em precedente sobre o tema ${ }^{211}$.

Na Europa continental o devido processo legal é mais conhecido como processo equo e giusto, ou justo processo regulado por lei, cláusula que marcou a constituição italiana, mas que é entendida não apenas como uma garantia de legalidade, e sim de um processo ético e efetivo ${ }^{212}$, em que as partes estejam em situações equilibradas, com paridade de $\operatorname{armas}^{213}$ e possibilidade de fruir do direito pleiteado, ou seja, um núcleo mínimo de garantias que visam não somente resguardar a defesa como também a utilidade dos direitos $^{214}$, pois do contrário jamais se poderia falar em processo justo.

\footnotetext{
${ }^{210}$ Ibid., p. 47-48.

211 BRASIL. Supremo Tribunal Federal. ADI 173/DF, relator: Min. Joaquim Barbosa, julgamento: 25/09/2008, órgão julgador: Tribunal Pleno, requerente: Confederação Nacional da Indústria - CNI, requerido: Congresso Nacional, publicação: DJ 20-03-2009. Disponível em: <http://www.stf.jus.br/portal/jurisprudencia>. Acesso em: 03 de abr. 2014.

${ }^{212}$ Giuseppe TARZIA. Il giusto processo diesecuzione. RivistadiDirittoProcessuale, p. 339

${ }^{213}$ Nicola PICARDI. Il principio delcontraddittorio. RivistadiDirittoProcessuale, p. 679-680.

${ }^{214}$ José Rogério Cruz e TUCCI. “Garantia da prestação jurisdicional sem dilações ...”In: José Rogério Cruz e TUCCI; Rogério Lauria TUCCI. Devido processo legal e tutela jurisdicional, p. 106. Segundo o autor: O processo, como é curial, presta-se à concreção do direito a jurisdição, sendo que seu desenrolar, com estrita
} 
Percebe-se assim, que uma interpretação lastreada no método histórico não nos conduzirá a conclusão, de que a cláusula do devido processo legal signifique o dever de observância somente daquilo que esteja expressa e minuciosamente previsto em lei, mas sim como uma cláusula de justiça procedimental, que imponha ao Estado o dever de observância de um núcleo mínimo de garantias de defesa para o processado, tais como contraditório, ampla defesa, fundamentação, publicidade, imparcialidade e efetividade, e também de uma justiça substancial, fundada na razoabilidade e proporcionalidade dos atos estatais $^{215}$.

Não obstante, outros argumentos ainda devem ser levantados, a fim de que se enxergue que os preceitos constitucionais também são preceitos normativos, que englobam também efetividade, sendo impossível ao legislativo e à sua atividade, o acompanhamento do dinamismo social em suas relações jurídicas.

Ainda que se reduzisse o significado do devido processo legal à estrita obediência da lei, deveríamos então começar pela plena observância da lei de maior hierarquia, ou seja, a Constituição Federal, emprestando significado e eficácia às suas normas, mormente aquelas que garantem o direito de peticionar ao Poder Público visando a uma efetiva proteção dos direitos violados e a inafastabilidade da Jurisdição.

Tais direitos e garantias, se interpretados de maneira substancial, além da sua literalidade, de modo a se extrair toda sua real, plena e potencial eficácia, impedem que o devido processo legal se reduza a literalidade das regras, e impõem que o processo seja apto a propiciar o seu objetivo da maneira mais célere e segura possível.

Obviamente, tais normas gozam de uma abertura estrutural enorme (clausulas gerais), pois não indicam os meios para o alcance de tal finalidade, nem a sanção para o caso de descumprimento, mas isso não lhes retira a eficácia plena e imediata, que, muito pelo contrário, foi declarada constitucionalmente com status de cláusula pétrea.

Nesse cenário, não se pode negar que a compatibilidade do devido processo legal com as demais cláusulas fundamentais de acesso à justiça impede que o significado da primeira seja reduzido a observância da literalidade da regra processual, e impõe que tal norma seja entendida como a necessidade de se garantir ao cidadão um processo equilibrado, com igualdade de participação e paridade de armas, e ao mesmo tempo

observância dos regramentos ínsitos ao denominado dueprocessoflaw, importa a possibilidade de inarredável tutela do direito subjetivo material objeto de reconhecimento, satisfação ou assecuração, em Juízo. ${ }^{214}$

${ }^{215}$ COMOGLIO, op. cit. p. 48, nota 209. 
efetivo $^{216}$, ou seja, capaz de concretizar no plano dos fatos os resultados jurídicos alcançados, de modo a se aproximar o máximo possível do cumprimento espontâneo do direito.

Restringir o significado do devido processo legal a observância estrita das regras processuais seria o mesmo que negar todo o sistema constitucional processual, com os direitos e garantias fundamentais que lhe são pertinentes num cenário neo-positivista, emque os valores encerrados nas normas constitucionais são reconhecidamente eficazes, dependendo muitas vezes de prestações positivas, cujo excesso ou omissão deverão ser controlados pelo Judiciário.

Tais digressões nos permitem concluir que o devido processo legal, ou o processo equo e giusto, não representaria óbice algum a proposta de coletivização judicial de demandas individuais.

Por fim, não custa lembrar a total impossibilidade de se exigir do legislativo a mesma dinâmica apresentada pelas situações da vida moderna, onde as relações jurídicas, muito por causa da intensa evolução tecnológica, a todo momento se alteram e se complexificam, sem que a atividade legislativa de conta de normatizar, formal e materialmente, as nova situações que surgem.

Desse modo, forçoso admitir que a proposta em estudo, de coletivização judicial de demandas individuais, não encontra óbice constitucional algum, seja para sua adoção de lege lata ou de lege ferenda.

\section{UMA PERSPECTIVA INFRACONSTITUCIONAL SOBRE O ASSUNTO}

Além de uma análise sobre a repercussão da proposta contida neste trabalho no âmbito constitucional, mostra-se necessária ainda uma análise similar, mas com o foco voltado para a esfera infraconstitucional, onde princípios como o da inércia, da adstrição da sentença ao pedido e a causa de pedir, e o principio dispositivo poderiam se mostrar incompatíveis com a ideia de coletivização de demandas individuais.

${ }^{216}$ TUCCI, op. cit. p. 106-107, nota 214. 
Nesse sentido, o princípio da inércia ou da demanda, que veda a instauração oficiosa de qualquer processo jurisdicional, com raríssimas exceções expressamente previstas no sistema ${ }^{217}$, poderia ser suscitado por alguns como um aparente óbice a técnica de coletivização judicial de oficio de demandas individuais, entretanto, algumas considerações em sentido contrário merecem ser feitas.

Primeiro, porque vedar a instauração oficiosa de processos jurisdicionais não significa a mesma coisa que vedar a coletivização de um processo jurisdicional que já está em tramite, concluindo-se que uma simples interpretação literal da norma que positiva tal princípio não conduziria a identificação de um óbice à ideia de coletivização judicial de oficio de demandas individuais.

Outrossim, se analisarmos o fato de que a concepção de tal princípio ocorreu de maneira totalmente alheia a ideia de coletivização de demandas individuais, pois vivia-se num cenário completamente individualista do processo ${ }^{218}$, poderemos concluir que de nenhuma forma esse princípio teve por finalidade criar óbice a presente proposta.

Isso não significa uma negativa de vigência ao principio da inercia, muito pelo contrário, já que é inconteste a importância dele para a preservação da imparcialidade ${ }^{219} \mathrm{e}$ do próprio fim jurisdicional de pacificação social, mas deve-se esclarecer que a aplicação deste princípio deverá ocorrer apenas para ahipótese para qual ele foi concebido, merecendo uma leitura que não ignore as idiossincrasias e necessidades dos tempos atuais, em que uma única relação jurídica é compartilhada por milhares de pessoas ou se replica em milhares de relações jurídicas similares.

Se levadas em conta tais ponderações, poderá se concluir que não há qualquer incompatibilidade entre o princípio da inércia e a ideia de coletivização de oficio de demandas individuais.

\footnotetext{
${ }^{217}$ José Carlos BARBOSA MOREIRA. “O problema da 'divisão do trabalho' entre juiz e partes: aspectos terminológicos."Revista de Processo, p. 8-10. No mesmo sentido: Humberto THEODORO JÚNIOR. Curso de direito processual civil,p. 517.

${ }^{218}$ Ada Pellegrini GRINOVER. "Direito Processual Coletivo". In: Ada Pellegrini GRINOVER et al. Direito processual coletivo e o anteprojeto de código brasileiro de processos coletivos, p. 11. Segundo a autora, o processo coletivo passou a ter mais importância no Brasil - um dos pioneiros dentre os países de civil law, a partir da década de 80, com a criação de Lei de Ação Civil Pública e a Constituição Federal.

${ }^{219}$ Andrea PROTO PISANI. In: Enrico ALLORIO (Coord). Comentariodelcodice de proceduracivile, apud BARBOSA MOREIRA, op. cit. p. 13, nota 217. No mesmo sentido: THEODORO JUNIOR, op. cit. p. 517, nota 217.
} 
No que tange ao principio da adstrição ou congruência da sentença com o pedido, que veda o julgamento sobre objetos não articulados na inicial ${ }^{220}$, merece diferenciação a hipótese em que a coletivização envolve direitos indivisíveis, da hipótese em que a coletivização envolve direitos individuais homogêneos.

No primeiro caso a coletivização de demanda individual não implicará em nenhuma violação a adstrição da sentença ao pedido, pois se o objeto da demanda é indivisível, naturalmente os fatos articulados na inicial já serão suficientes para uma demanda coletiva e os pedidos fatalmente envolverão o objeto único, que não sofrerá qualquer ampliação.

Contudo, nos casos de direitos individuais homogêneos haverá sim uma releitura desse princípio, pois ao coletivizar uma demanda individual, quando identificar a possível existência de direitos com origem comum, o magistrado estará considerando fatos não mencionados na inicial e objetos distintos também.

Nesse sentido, deve-se esclarecer de imediato, que a concepção do princípio em análise também não considerou a realidade atual, tendo sido voltada para uma era totalmente individualista do processo, que ignorava por completo o hodierno contexto de demandas repetitivas e de massificação do acesso à justiça.

A finalidade da norma em questão também foi a de evitar a parcialidade no julgamento e o prejuízo ao contraditório, e a ampla defesa, pois julgando fatos ou objetos não trazidos na inicial o juiz demonstra conhecer os fatos específicos de maneira extraprocessual e impede que a parte contrária reaja, se opondo ao resultado que lhe poderá ser desfavorável.

Ocorre que, isso será verdade no caso em que uma demanda individual tenha fatos ou objetos não reivindicados, envolvendo as mesmas partes, submetidos a julgamento de oficio, contudo, no caso em que uma demanda individual é convertida em coletiva, o juiz não demonstra ter conhecimento específico sobre outro caso particular envolvendo as mesmas partes, de modo que sua imparcialidade não ficará comprometida.

Ele apenas deduz, com base em máximas de experiência, ou seja, naquilo que normalmente acontece ${ }^{221}$, levando em conta o conhecimento disseminado no âmbito geral

\footnotetext{
${ }^{220}$ THEODORO JUNIOR, op. cit. p. 517, nota 217.

${ }^{221}$ Michele TARUFFO. Funzionedella prova: lafunzionedimostrativa. Sui confini: scrittisullagiustiziacivile.p. 314.
} 
da civilização humana ${ }^{222}$, que existem relações jurídicas com origem similar àquela, de modo que o seu julgamento possa ser aproveitado para favorecer a todos que se encontrem em tal situação, proporcionado economia processual, celeridade, efetividade na proteção do direito material e segurança jurídica.

Todos esses resultados, precedidos de um debate com as partes, que proporcione o exercício do contraditório e da ampla defesa, não podem ser identificados como uma forma de se aviltar o direito a imparcialidade e ao contraditório amplo.

Insista-se, que na proposta em tela o juiz não demonstra ter conhecimento de um caso específico extraprocessual, envolvendo as mesmas partes, mas sim o conhecimento de que aquela situação sub judice se repete com inúmeras outras pessoas, de modo que a ausência de uma atuação coletiva leve ao total congestionamento da atividade jurisdicional e, consequentemente, à sua total ineficácia, por conta de demandas praticamente idênticas.

Repita-se também, que o objetivo inicial da vedação ao conhecimento de fatos ou objetos não realizados na inicial foi direcionado a impedir que o juiz decida causas diferentes daquelas trazidas pelas partes, mas envolvendo-as, o que poderia gerar a sua parcialidade e também prestigiar a hostilidade entre elas, situação que não ocorre no caso de coletivização de uma demanda individual.

Na proposta em foco, o juiz irá apenas ampliar o alcance da atividade jurisdicional desempenhada, levando em conta fatos e objetos não expressos na inicial, mas que estão sendo ou que poderiam ser repetidos em milhares de outras ações individuais, o que será realizado justamente para evitar tal fenômeno, reduzindo o impacto da massificação das relações sociais, com economia processual, celeridade, efetividade na proteção dos direitos e segurança jurídica.

Conclui-se assim, que a interpretação do princípio da adstrição da sentença ao pedido e a causa de pedir deverá levar em conta a nova realidade social, com as demandas e necessidades que lhe são típicas, diferentes das anteriores, a fim de que a atividade jurisdicional não se anule num completo imobilismo ante ao anacronismo de determinadas interpretações normativas, impertinentes e inadequadas ao contexto atual.

Por fim, deve-se falar a respeito da influência do princípio dispositivo na análise em questão, já que, pela sua nomenclatura e origem, pode-se constatar sua íntima relação com a

\footnotetext{
${ }^{222}$ Michele TARUFFO. Senso comune, esperienza e scienza ...Sui confini: scrittisullagiustiziacivile,p. 125 e 145 .
} 
ideia de disponibilidade do direito material, que deverá permanecer disponível mesmo após se tornar litigioso ${ }^{223}$.

Primeiro, destaca-se que esse princípio tem provocado ao longo do tempo diversas interpretações diferentes, que divergem no que tange a sua amplitude de incidência, ao ponto da corrente mais ampliativa o enxergar multifacetada, com as seguintes funções: a) impedir a instauração de oficio de processo jurisdicional; b) impedir o julgamento de objeto diverso do processo; c) impedir o magistrado de considerar fatos e produzir provas de oficio; d) impedir o magistrado de interferir nos atos de disposição patrimonial $^{224}$.

Uma corrente intermediária defende que tal princípio teria apenas a função de impedir a consideração de fatos e a produção de provas de ofício,alémda interferência em atos de disposição ${ }^{225}$, enquanto uma terceira, mais restritiva, lhe atribui apenas a função de impedir a interferência em atos de disposição de direito ${ }^{226}$.

Em nossa ótica, que acompanha doutrinadores de $\operatorname{escol}^{227}$, a corrente mais acertada é também a mais restritiva, já que as demais funções, de impedir a instauração de ofício de processo jurisdicional e de impedir a consideração de fatos, e a produção de provas, de oficio, já possuem outros princípios que lhe emprestam normatividade, tais como o princípio da inércia e da adstrição da sentença ao pedido e a causa de pedir, falados no início do capítulo, e o principio inquisitivo, que disciplina a atuação jurisdicional de modo a permitir a atuação probatória oficial ${ }^{228}$.

Outrossim, não há qualquer relação entre a disponibilidade do direito e o dever de inércia e adstrição da sentença ao pedido e a causa de pedir, pois nem nos casos de direitos indisponíveis as respectivas providencias oficiais são admitidas pelo ordenamento jurídico pátrio, que ao contrário, admite a relativização do dever de inércia e de adstrição em casos excepcionais de direitos disponíveis ${ }^{229}$.

O dever de inércia e adstrição da sentença ao pedido e a causa de pedir estão, como dito acima, ligados à ideia de imparcialidade, redução da litigiosidade e fruição do

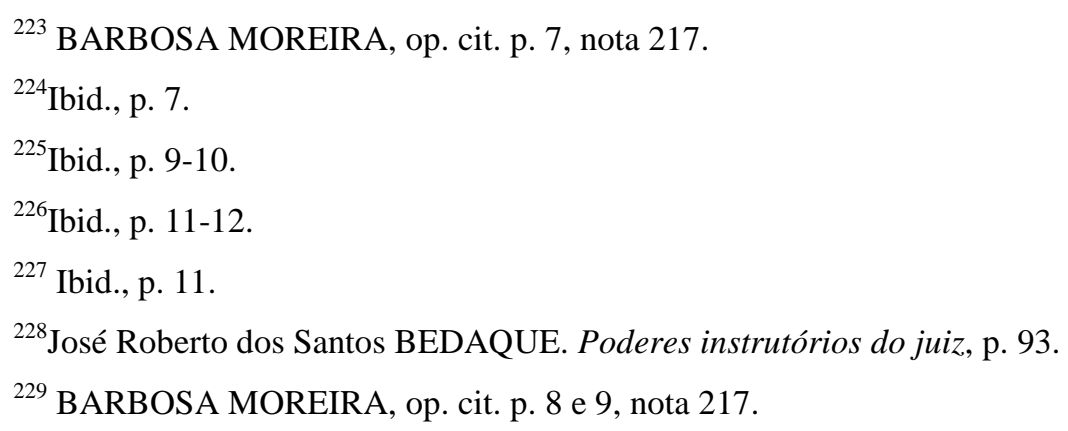


contraditório, pois se tem a noção, de que o juiz que instaura um processo de oficio, julga objeto diverso do litigioso ou leva em conta fatos que não foram narrados, não poderá ser considerado plenamente isento, nem um ente pacificador de conflitos, mas sim multiplicador dos mesmos, além do risco impingido ao contraditório quando fatos são conhecidos sem que haja um prévio debate.

Ainda assim, alguém poderia suscitar então, que ao coletivizar de oficio uma demanda individual, especificamente nos casos de direitos individuais homogêneos, o magistrado estaria interferindo no direito a disponibilidade que os indivíduos possuem em relação aos seus direitos, o que, entretanto, não é verdade, já que em qualquer momento a parte poderá expressamente renunciar ao seu direito individual ou, ainda, não liquidá-lo.

Aliás, da mesma forma que a tutela coletiva pode ser instaurada por um único representante, sem que isto configure violação à disponibilidade dos direitos, a tutela individual poderá ser coletivizada sem tal óbice, cabendo salientar que em muitos casos os direitos individuais homogêneos são indisponíveis, por se relacionarem a direitos do consumidor, do trabalhador ou de outros segmentos reconhecidamente vulneráveis.

Destarte, conclui-se que o principio dispositivo não representa óbice à atuação oficial do juiz, para converter demandas individuais em coletivas, pois ao agir dessa maneira o magistrado não impede o individuo de dispor dos seus direitos, mas apenas amplia o alcance da tutela coletiva para aqueles que quiserem ser tutelado com mais efetividade, sendo certo que, mesmo que houvesse qualquer prejuízo à disponibilidade do direito material, este não seria considerado em grande parte dos casos, em que serão tratados direitos indisponíveis.

\section{A INSTRUMENTALIDADE DO PROCESSO E A TECNICA DE COLETIVIZAÇÃO DE DEMANDAS: aspecto positivo e negativo}

Além de toda análise tecida a respeito da ausência de óbices legítimos, constitucionais e infraconstitucionais, à proposta em tela, de coletivização judicial de ofício de demandas individuais, mostra-se pertinente também, a consideração da influência da teoria da instrumentalidade do processo sobre o presente tema. 
Nesse cenário, é importante que se introduza o respectivo assunto, esclarecendo que a instrumentalidade das formas é uma vertente da instrumentalidade processual, denominada por Dinamarco de aspecto negativo da instrumentalidade, ou seja, o aspecto que nega a importância da forma pela forma, impondo que o processo seja aproveitado mesmo quando tenham atos omitidos ou praticados incorretamente, desde que isto não gera prejuízo a nenhuma garantia processual das partes ${ }^{230}$.

$\mathrm{O}$ aspecto positivo da instrumentalidade do processo impõe que do processo e dos seus atos seja extraída a máxima eficácia no alcance dos tradicionais escopos processuais $^{231}$, já que, normalmente, é isto que se espera de qualquer instrumento ou ferramenta, como é o processo em relação ao direito material.

Desse modo, a instrumentalidade do processo, numa vertente positiva, de afirmação do processo como meio efetivo, impõe uma nova postura dos operadores do direito e do legislativo, que deverão, no desempenho de suas atividades, primar pela universalização do acesso à justiça, ou melhor, à ordem jurídica justa, com a criação de juizados especiais, o maior uso do processo coletivo, o prestígio as atividades de conciliação e ao alcance da verdade dos fatos, além de outras medidas tendentes a oferecer mais celeridade e segurança aos resultados da atividade jurisdicional ${ }^{232}$.

Relacionando tais teorias com a proposta em tela pode-se dizer que ambas lhe dão sustentação.

A instrumentalidade das formas concede subsídio argumentativo à ideia de coletivização judicial de oficio de demandas individuais, pois, a menos que tal conduta represente prejuízo a alguma garantia processual, tal como contraditório, ampla defesa, juiz natural, devido processo legal, inércia ou outra, não haverá como se falar em nulidade quando um juiz converter, de oficio, uma ação individual em coletiva.

Se a instrumentalidade das formas preconiza que o processo e seus atos sejam aproveitados quando a informalidade não resultar em prejuízo a alguma garantia processual das partes, naturalmente pode-se concluir que, se a coletivização de uma demanda individual não trouxer qualquer prejuízo neste sentido, merecida será a aplicação

\footnotetext{
${ }^{230}$ Candido Rangel DINAMARCO. A Instrumentalidade do Processo, p. 381. No mesmo sentido: José Roberto dos Santos BEDAQUE. Efetividade do processo e técnica processual, p. 67 e 99.

${ }^{231}$ Ibid., p. 386. (DINAMARCO)

${ }^{232}$ Ibid., p. 400.
} 
da instrumentalidade das formas, para se permitir o aproveitamento da atividade jurisdicional em concreto.

Por outro lado, a instrumentalidade do processo, em seu aspecto positivo, também concede subsídio argumentativo à proposta em tela, pois na medida em que preceitua a máxima extração de eficácia dos instrumentos processuais, com mudanças posturais que devem desaguar num mais amplo e qualificado acesso à justiça, se identifica com tudo que vem sendo dito a respeito da coletivização de demandas individuais e seus prováveis resultados.

Como visto nos tópicos anteriores, a ampliação do uso da tutela coletiva permitirá o alcance de resultados mais céleres e uniformes ${ }^{233}$, aumentando a efetividade da jurisdição na proteção dos direitos materiais, inclusive de alguns que jamais seriam objetos de tutela - seja pelo seu baixo valor econômico seja pela vulnerabilidade de seus detentores, bem como a compatibilidade entre as decisões judiciais, principalmente aquelas que decidam sobre direitos indivisíveis.

Nesse sentido, percebe-se que a ampliação do uso da tutela coletivo vai ao encontro da ideia de instrumentalidade do processo, não sendo outra a razão que conduziu o CÂNDIDO RANGEL DINAMARCO a criticar o uso tímido dessa modalidade de tutela, para a qual tão poucos entes encontram-se expressamente legitimados pela lei ${ }^{234}$.

Destarte, se a coletivização judicial de oficio de demandas individuais é capaz de proporcionar a ampliação do uso da tutela coletiva, por razões claras, já que transcende o problema da legitimidade e da iniciativa, atingindo a extensão que os resultados da atividade jurisdicional deverão ter na atual conjuntura, será forçoso concluirmos que ela se mostra confluente com os ideais da instrumentalidade do processo, de ampliação da sua eficiência, pois isso é um consectário natural da ampliação do uso da tutela coletiva.

Obviamente, que tal aumento de eficiência não poderá ocorrer a todo custo, ou seja, com o sacrifício das garantias constitucionais, mas a todo o momento tem se mostrado e discutido, que a ideia de coletivização de demandas individuais, no modelo ora proposta, não representa nenhum prejuízo a qualquer garantia processual, seja de índole constitucional ou infraconstitucional.

\footnotetext{
${ }^{233}$ José Carlos BARBOSA MOREIRA. "Notas sobre o problema da 'efetividade' do processo". Revista da AJURIS,p. 77-78. Ver também: José Carlos BARBOSA MOREIRA. "A efetividade do processo de conhecimento." Revista de Processo, p. 128-129.

${ }^{234}$ DINAMARCO op. cit. p. 397, nota 229.
} 
Conclui-se, portanto, que os objetivos da técnica processual ora proposta estão condizentes com a instrumentalidade do processo, tanto em seu aspecto positivo, como em seu aspecto negativo, motivo pelo qual o presente trabalho se apropria dos fundamentos da instrumentalidade para defender a coletivização judicial de oficio das demandas individuais que se apresentarem aptas a tanto, conforme os requisitos explicitados acima, que deverão sempre ser observados. 


\section{UMA ANÁliSE DA AUSÊNCIA DE PREVISÃo LEGAL EXPRESSA SOBRE A LEGITIMIDADE INDIVIDUAL PARA DEMANDAS COLETIVAS E SUA INFLUÊNCIA SOBRE O TEMA}

Talvez o principal problema a ser enfrentado pela temática em questão, de coletivização judicial de demandas individuais, seja a ausência de regra expressa, que atribua ao indivíduo, legitimidade para a propositura de demanda coletiva, sendo que, via de regra, sempre que o juiz coletivizar uma demanda individual, ele esbarrará neste suposto óbice.

No ordenamento jurídico pátrio, os dois principais diplomas existentes em relação ao processo coletivo, quais sejam: a Lei de Ação Civil Pública e o Código de Defesa do Consumidor, não preveem legitimidade para o indivíduo atuar como substituto processual em demandas coletivas, omissão que, obviamente, é interpretada pela doutrina tradicional como uma ausência de legitimidade individual para demandas coletivas ${ }^{235}$.

Apenas a Lei de Ação Popular prevê a possibilidade do cidadão ingressar com demanda coletiva, visando à proteção do patrimônio público contra atos lesivos a este e aos bens indicados modernamente pelo constituinte ${ }^{236}$.

\footnotetext{
${ }^{235}$ Ricardo de Barros LEONEL. Manual do processo coletivo, p. 162.

${ }^{236}$ Ibid., p. 116.
} 
Além disso, outros exemplos existem, em que um indivíduo atua como substituto processual, numa sistemática muito parecida com a dos processos coletivos, sem que a lei reconheça expressamente tal situação, o que será melhor enfocado mais abaixo, quando tratadas as hipóteses de coletivização de demandas individuais versando sobre bens indivisíveis, suscitando-se os exemplos das ações anulatórias de assembleias de sociedades anônimas ou condominiais, de demandas possessória envolvendo bens condominiais e de cobrança de crédito com credores solidários.

Contudo, para nós, a ausência de previsão expressa não significa um óbice intransponível à conclusão de que, no atual sistema jurídico, o indivíduo aparenta possuir legitimidade para propor ações coletivas.

A ausência de previsão não pode significar automaticamente uma vedação, principalmente, se considerarmos o arsenal axiológico contido em nossa constituição, que despeja uma carga ética significativa no modelo constitucional de processo ${ }^{237}$ e impõe um ideal de maximização da justiça ${ }^{238}$, sem perda de segurança ou inobservância dos demais valores, o que parece se coadunar com uma ampliação da legitimidade para demandas coletivas, e não para o seu encurtamento, como se verá nos tópicos seguintes.

Os argumentos contrários orbitam basicamente em torno do risco do processo coletivo ser utilizado com fins espúrios, por indivíduos que visam apenas ao beneficio singular, sem qualquer preocupação com a coletividade ali representada, o que poderia gerar prejuízos desnecessários aos réus, obrigados a se defenderem em processo iniciados sem qualquer fundamento legítimo ${ }^{239}$, e à coletividade, que má representada, poderia ser prejudicada com resultados desfavoráveis ${ }^{240}$.

\footnotetext{
${ }^{237}$ Luis Roberto BARROSO. Fundamentos teóricos e filosóficos do novo direito constitucional brasileiro. In: p. 28. (Org.). A nova interpretação constitucional: ponderação, direitos fundamentais e relações privadas,

${ }^{238}$ Candido Rangel DINAMARCO. A instrumentalidade do processo, p. 391. Para o autor: "A universalidade da tutela jurisdicional constitui acentuadíssima tendência generosa da atualidade e está presente nas preocupações e nos movimentos dos processualistas mais modernos. As tradicionais limitações ao ingresso na Justiça, jurídicas ou de fato (econômicas, sociais) são óbices graves à consecução dos objetivos processuais e, do ponto-de-vista da potencial clientela do Poder Judiciário, constituem para cada qual fator de decepções em face de esperanças frustradas e insatisfações que se perpetuam; [...]", o que contribui e estimula os estudos de processo com o foco voltado para técnicas capazes de proporcionar maior eficácia, sem perda de qualidade.

${ }^{239}$ Aluisio Gonçalves de Castro MENDES; Larissa Clare Pochmann da SILVA. "A legitimidade ativa do indivíduo nas ações coletivas." Revista de Processo,p. 39.

${ }^{240}$ Ibid., p. 37-38.
} 
Nesse contexto, esses argumentos passam a ser enfrentados um a um, de modo a se alcançar uma conclusão ao final, sobre a existência ou não de legitimidade individual para o ajuizamento de ações coletivas.

\subsection{Os mecanismos de inibição do abuso processual}

Um dos principais argumentos utilizados por quem se opõe a legitimação individual para a propositura de ações coletivas se baseia na possibilidade de tais demandas serem ajuizadas de maneira abusiva, com o objetivo de atender apenas ao interesse individual do autor ou de alguém que esteja por de trás deste, manipulando os seus atos ${ }^{241}$.

Tentando ilustrar esse risco, por vezes se recorre ao exemplo da ação popular, que em alguns casos é utilizada com fins eleitoreiros, visando não à defesa do patrimônio público, mas sim o constrangimento e a difamação de um politico ${ }^{242}$, que mesmo não tendo praticado qualquer ilegalidade, seria injustamente processado para somente ao final ser reconhecido como probo.

Nada obstante à aparente pertinência de tais argumentos, os mesmos parecem não prosperar, pois existem no sistema jurídico atual, os mecanismos adequados à inibição do uso abusivo do processo, não só em âmbito coletivo, como também no plano das demandas individuais.

\footnotetext{
${ }^{241}$ Ada Pellegrini GRINOVER; Nelson NERY JÚNIOR;Kazuo WATANABE et al. Código Brasileiro de Defesa do Consumidor: comentado pelos autores do anteprojeto, 9.ed. p. 834. Segundo os autores: "Pelas regras que disciplinam as obrigações indivisíveis, seria admissível, em linha de princípio, a legitimação concorrente de todos os indivíduos para a defesa dos interesses difusos ou coletivos de natureza indivisível. Mas ponderações várias, como as pertinentes ao conteúdo politico das demandas, à possibilidade de pressões quanto à propositura e prosseguimento da demanda, à produção de provas adequadas e ao prosseguimento destemido nas instâncias superiores, e a necessidade, enfim, de um fortalecimento do autor da demanda coletiva, fizeram com que se excluísse a legitimação individual para a tutela dos consumidores a título coletivo".

"Algumas experiências vividas no campo da ação popular, que tem sido utilizada, com alguma frequência, como instrumento politico de pressão e até de vindita, serviram também para o perfilhamento da opção legislativa mencionada". Percebe-se então, que o receio da doutrina com relação a legitimidade individual para a demanda coletiva, gravita em torno da desconfiança sobre a idoneidade do interesse subjacente a propositura da ação coletiva, que poderia ser egoístico ou objeto de manipulação politica, e da desconfiança sobre a capacidade do individuo realizar uma boa representação, livre de pressões, com suficiente produção de provas e franca atuação nos Tribunais. Por rumo semelhante: Elton VENTURI. Processo civil coletivo: a tutela jurisdicional dos interesses difusos, coletivo e individuais ..., p. 169-172.

${ }^{242}$ Ibid., p. 834.
} 
Assim, por exemplo, o Código de Processo Civil autoriza a aplicação de multas e a fixação de indenizações, quando se concluir que a parte tenha agido com má-fé num processo, deduzindo pretensão sabidamente inviável, alterando a verdade dos fatos ou visando à satisfação de um objetivo ilegal.

A multa por conta da prática de tais atos pode ser baixa, mas existe a possibilidade de ser fixada indenização também, a fim de compensar os eventuais danos causados pelo processo abusivo.

Temor parecido, mas relacionado ao uso abusivo das ações coletivas pelas associações, já foi objeto de estudo dos autores Grinover, Watanabe, Nery Júnior e outros, que rechaçaram tal receio, entendendo que "o legislador cuidou de prever sanções para a litigância de má-fé, estabelecendo a penalização não somente da associação, como também dos diretores responsáveis pela propositura da ação (art. 87 e paragrafo único)"243.

No mesmo sentido, a Lei de Ação Popular $^{244}$ e a de Ação Civil Pública - que se remete ao CDC neste assunto, também preveem mecanismos de inibição da má-fé processual em casos de demandas coletivas, com multas baseadas no décuplo das custas processuais, que também não impedem a fixação de indenização processual cumulativamente $^{245}$.

Outrossim, não bastassem esses mecanismos de apenamento do litigante de má-fé, existem ainda mecanismos de economia processual, que impedem o desenvolvimento desnecessário de demandas manifestamente inadmissíveis ${ }^{246}$.

Nesse sentido, por exemplo, eventual petição inicial que contenha pretensão ilegítima, travestida de demanda coletiva, poderá de plano ser indeferida, quando

\footnotetext{
${ }^{243}$ Ibid., p. 842.
}

${ }^{244}$ José Carlos BARBOSA MOREIRA. “A ação popular no direito brasileiro como instrumento de tutela jurisdicional dos chamados 'interesses difusos". Revista de Processo, p. 13. JOSÉ CARLOS BARBOSA MOREIRA visualiza a possibilidade de o juiz fixar multa baseado no decuplo do valor das custas, como uma forma de se "desestimular as iniciativas sem seriedade, maliciosas, mal intencionadas, nascidas de mero capricho ou do desejo de intimidar ou por em situação incomoda perante a opinião publica autoridades pouco dispostas a satisfazer pretensões ilegítimas."

${ }^{245}$ Ibid., p. 13. Ensina o autor carioca ainda, que: "A sanção prevista na regra especifica do art. 13 da Lei 4.717 não exclui, aliás, a incidência das normas codificadas acerca da responsabilidade por dano processual: [...]".

${ }^{246}$ José Roberto dos Santos BEDAQUE. Efetividade do processo e técnica processual,p. 259. Segundo JOSE ROBERTO DOS SANTOS BEDAQUE: “A compreensão da técnica representada pelas condições da ação possibilita que, verificada a ausência de uma delas, o processo seja extinto o quanto antes - o que atende ao principio da economia processual. Se a sentença de mérito é inadmissível, melhor impedir o desenvolvimento inútil da atividade jurisdicional". 
juridicamente impossível o seu pedido ou sua causa de pedir, ou quando o pedido não decorrer logicamente dos fatos, podendo ainda ter de plano o seu mérito analisado e repelido, caso o mesmo juízo tenha proferida sentenças de improcedências em causas similares.

Percebe-se então, que o sistema já se encontra devidamente provido dos meios necessário a obstar o uso abusivo do processo, seja ele individual ou coletivo, com mecanismos que não só apenam o autor, como também impedem o curso desnecessário de processos infrutíferos.

Se os mecanismos existentes são brandos ou insuficientes, dependeriam de reforma legislativa que os recrudescessem ou aumentassem sua amplitude, e não de entendimento que restrinja a legitimidade individual para demandas coletivas, pela aparente desproporcionalidade em tal restrição.

A proporcionalidade de um ato ou uma norma, como já visto, se afere pela sua adequação ao fim pretendido, pela necessidade de sua adoção, sem que haja alternativa menos sacrificante aos valores conflitantes, e pelo sopesamento entre os direitos envolvidos ${ }^{247}$.

No caso em tela, pode-se enxergar que a restrição à legitimidade individual para demandas coletivas não é adequada para evitar o abuso do processo, pois este poderá ser praticado também pelos entes legitimados, como, por exemplo associações, que sejam constituídas ou manipuladas com tal fim, ante a facilidade existente para tanto.

Ainda que se concebesse como adequada a propiciar a segurança anunciada, a restrição à legitimidade individual para demandas coletivas ainda se mostraria desnecessária, ante a existência de outros meios, mais aptos à inibição do uso abusivo da tutela coletiva, como a aplicação de multa, fixação de indenização, extinção liminar do processo - todas estas já existentes no ordenamento pátrio, e até a criação de um cadastro que restrinja o acesso a demandas coletivas apenas ao individuo com histórico de litigância de má-fé.

Conclui-se, assim, que a restrição à legitimação individual para demandas coletivas não é capaz de evitar demandas abusivas, já havendo ferramentas para tanto no sistema

\footnotetext{
${ }^{247}$ Virgílio AFONSO DA SILVA. Direitos fundamentais: conteúdo essencial, restrições e eficácia, p. 174175 .
} 
atual, mostrando-se ainda desnecessária, ante a desnecessária limitação que tal restrição traz ao direito fundamental de acesso à justiça.

Desse modo, o argumento ora enfrentado mostra-se aparentemente frágil e desproporcional, não devendo prosperar face às razões ora espraiadas.

\subsection{O risco de má representação pelo indivíduo e sua mitigação pela participação obrigatória do Ministério Público}

Outro argumento, utilizado por quem se opõe à abertura da legitimidade ativa nas ações coletivas, é o de que a má representação da coletividade poderia acarretar prejuízos para esta, já que muitos indivíduos não teriam condições de contratar bons escritórios de advocacia para atuarem no feito, nem teriam condições de arcar com custos relacionados à produção de toda espécie de provas $^{248}$, ou o que é pior, poderiam se unir em colusão com a parte contrária ou desistir de demandas visando a benefícios individuais ${ }^{249}$.

Apesar de se basear num fato pacífico, qual seja: o de que a maioria da população brasileira não teria condições financeiras de sustentar um litigo coletivo com todos os investimentos que ele normalmente requer, tal argumento parece ignorar aspectos da legislação processual, que muito provavelmente afastariam os efeitos nocivos da carência econômica da população brasileira, bem como os entraves decorrentes de posturas desonestas.

O principal deles refere-se à necessária atuação do Ministério Público numa demanda coletiva ${ }^{250}$, independentemente do representante que se encontre no polo ativo desta, o que decorre de previsão expressa tanto na Lei de Ação Civil Pública como no Código de Defesa do Consumidor, e lhe confere as mesmas faculdades, ônus e deveres que

\footnotetext{
${ }^{248}$ Ada Pellegrini GRINOVER; Nelson NERY JÚNIOR;Kazuo WATANABE et al. Código Brasileiro de Defesa do Consumidor: comentado pelos autores do anteprojeto, 9.ed. p. 834 e 844.

${ }^{249}$ BARBOSA MOREIRA, op. cit. p. 12-13, nota 244.

${ }^{250}$ Ibid. p. 12-13. No mesmo sentido: Elton VENTURI. Processo civil coletivo: a tutela jurisdicional dos interesses difusos, coletivo e individuais ..., p. 169, entendendo que a intervenção do parquet reduz ao mínimo possível a chance de prejuízo pela má representação. Neste sentido também: Aluisio Gonçalves de Castro MENDES; Larissa Clare Pochmann da SILVA. "A legitimidade ativa do individuo nas ações coletivas." Revista de Processo,p. 42.
} 
teria como parte, cabendo-lhe recorrer das decisões injustas ${ }^{251}$ e aditar a peça inicial, quando esta lhe parecer carente de fundamentação ou de pedidos, mesmo porque, obrigá-lo a entrar com outra ação nestas hipóteses seria completamente anti-econômico ${ }^{252}$.

Outros aspectos, concernentes aos poderes instrutórios do juiz, aos benefícios da gratuidade de justiça e a existência da defensoria pública, também amenizam o problema da má representação que o indivíduo poderia proporcionar numa demanda coletiva, mas a atuação obrigatória do Ministério Público como custus legis parece afastar de uma vez por todas, quaisquer riscos ensejados por tal problema ${ }^{253}$, a não ser que se admita uma suposta hipossuficiência desse órgão, que muito pelo contrário, é composto na sua maioria por profissionais bem preparados e bem remunerados, ativos e comprometidos com o ideal que norteia as ações dessa instituição.

Dessa maneira, por exemplo, ainda que o mau profissional, contratado com um baixo custo pelo indivíduo, deixe o processo paralisado, não articule alguns fatos ou argumentos, não realize os pedidos adequados, não recorra da sentença, não produza determinada prova ou não tenha recursos financeiros para tanto, o representante do

\footnotetext{
${ }^{251}$ Hugo Nigro MAZZILlLI. A defesa dos interesses difusos em juízo: meio ambiente, consumidor, patrimônio ..., p. 78. Segundo o autor: "O princípio da obrigatoriedade ilumina não só a propositura da ação pelo Ministério Público, como também sua intervenção em ação já proposta. Tanto tem o dever de recorrer da sentença ilegal na ação civil pública que ajuizou como naquela em que compareceu como interveniente."

252 Ibid., p. 306-307. Também admitindo a intervenção litisconsorcial voluntária: Candido Rangel DINAMARCO. Litisconsórcio,p. 54-55, 333-335. Aliás, na página 334, CANDIDO RANGEL DINAMARCO expressamente exemplifica essa intervenção, utilizando-se o M.P.: "E também acontece a intervenção litisconsorcial voluntária de co-legitimados- pessoas portadoras de legitimidade em relação ao próprio objeto do processo pendente e que, por essa razão, poderiam figurar como litisconsorte desde o início. Pode-se pensar, a propósito, [...]; ou ainda no cidadão que ingressa no polo ativo de ação popular já proposta, ou mesmo na associação ou no Ministério Público como litisconsortes ulteriores voluntários na ação civil pública”. Apesar de o autor afirmar que a intervenção litisconsorcial de co-legitimados mantém integro o objeto do processo, isto não significa que o litisconsorte ulterior não possa trazer uma demanda conexa ou afim, já que esta ampliação ocorre quando não há co-legitimidade entre os litisconsortes - apenas conexão ou afinidade de questões (p. 334). A construção do autor parece mais concernir ao que normalmente acontece, do que ao que efetivamente pode acontecer.

${ }^{253}$ Em interessante artigo BRUNO SILVEIRA DE OLIVEIRA defende a legitimidade subordinada do individuo, para ações coletivas versando sobre direitos difusos ou coletivos stricto sensu, com espeque no direito fundamental de acesso à justiça. Contudo, o individuo ficaria dependendo da participação do Ministério Público, que o próprio autor afirma ser obrigatória por lei sempre nessas hipóteses, como em todas as hipóteses relativas a processos coletivos. Sendo assim, pergunta-se, como se falar em legitimidade subordinada, se a circunstância à qual está submetida a legitimidade, deverá sempre ocorrer, por decorrência de lei, não ficando a disposição da vontade humana? Quando você subordina a legitimidade de alguém à participação de outrem, você o faz para que o outro participe da decisão pela propositura ou não da demanda, o que não será o caso do parquet, que deverá participar de todo processo coletivo, razão pela qual se propõe o seguinte raciocínio: se a participação do M.P. supre a complementa a legitimidade individual no caso de direitos indivisíveis, pois ele representa a coletividade, porque não supriria nos casos de direitos individuais homogêneos? Ver mais em: Bruno Silveira de OLIVEIRA. "Flexibilização do binômio 'processo tradicional' I 'processo coletivo'. Breve análise da presença do individuo em processos coletivos". Revista da Procuradoria Geral do Estado do Espirito Santo,p. 83-85.
} 
Ministério Público poderá fazê-lo, alegando o que tiver de ser alegado, pedindo o que tiver de ser pedido, interpondo o recurso pertinente e requerendo a prova cabível ${ }^{254}$, podendo eventuais custos serem ao final ressarcidos, caso haja a procedência dos pedidos.

É certo ainda, que em caso de abandono processual o Ministério Público já seria intimado a assumir a demanda de qualquer modo ${ }^{255}$, como dispõe a Lei de Ação Civil Pública, que fala ainda na atribuição desse órgão para executar as sentenças não executadas por mais de sessenta dias do trânsito em julgado.

Sendo assim, retoma-se a questão: a má representação decorrente da hipossuficiência econômica do individuo poderia efetivamente trazer prejuízo à tutela coletiva, mesmo com a intervenção obrigatória do Ministério Público no processo como fiscal da lei?

A resposta parece que será negativa, pois todas as omissões praticadas pelo indivíduo e seu advogado, inclusive com relação à causa de pedir, ao pedido, à instrução probatória e a interposição de recursos, poderão ser supridas pelo representante do parquet, que tem a atribuição legal de assim proceder, haja vista o interesse social que permeia as demandas coletivas e as previsões legais expressas neste sentido, insculpidas não só na Lei de Ação Civil Pública como no Código de Defesa do Consumidor também ${ }^{256}$.

Deve-se considerar ainda, que inúmeras associações, legitimadas para o uso da tutela coletiva, também não dispõem de condições financeiras privilegiadas para o sustento de uma grande lide coletiva, mas nem por isto a lei lhes caça a respectiva legitimidade ${ }^{257}$, mesmo porque, se assim o fizesse estaria estabelecendo tratamento altamente discriminatório.

\footnotetext{
${ }^{254}$ Ibid., p. 86. Segundo o autor: “[...] é próprio que o Ministério Público ajuíze a ação justamente para zelar pelo correto cumprimento da lei; e, mesmo quando seja mero interveniente, ainda é considerado parte na relação processual (podendo, v.g., produzir provas ou recorrer). Em sentido convergente: José Carlos BARBOSA MOREIRA. A ação popular no direito brasileiro como instrumento de tutela jurisdicional dos chamados "interesses difusos". Revista de Processo, p. 12-13. Para o autor carioca o parquet também pode “'apressar a produção da prova", e ainda "'juntar documentos e certidões, produzir prova em audiência e requerer medidas ou diligencias necessárias ao descobrimento da verdade"”, o que ele assere tendo como fonte subsidiária o CPC.

255 Ibid., p. 13.

${ }^{256}$ Bruno Silveira de OLIVEIRA. 'Flexibilização do binômio 'processo tradicional' / 'processo coletivo'. Breve análise da presença do individuo em processos coletivos". Revista da Procuradoria Geral do Estado do Espirito Santo,p. 84-85.

${ }^{257}$ Aluisio Gonçalves de Castro MENDES; Larissa Clare Pochmann da SILVA. "A legitimidade ativa do individuo nas ações coletivas." Revista de Processo,p. 41.
} 
Igualmente discriminatório é restringir a iniciativa individual para o ajuizamento de ações coletivas, sob o argumento de que o individuo não teria meios de suportar os custos de um processo coletivo ${ }^{258}$.

O acesso à justiça é um direito fundamental e, modernamente, não só o acesso ao instrumento de proteção dos direitos individuais deve ser assim considerado, como também o acesso ao instrumento de proteção dos direitos coletivos, envolvendo bens indivisíveis ou individuais homogêneos, de modo que, eventuais carências econômicas suportadas pelos indivíduos na realização desses direitos, devam ser assumidas pelo Estado ${ }^{259}$, e não servir de argumento para impedir que o indivíduo seja parte ativa legitima numa ação coletiva.

Quando se restringe a legitimidade individual para demandas coletivas, se restringe a liberdade individual e humana de assim proceder, tanto para a proteção de um bem indivisível como para a proteção de um bem individual, mas homogêneo.

Não se fala aqui, que o homem tem o dever de agir em prol da coletividade sempre que verificar uma lesão a esta, apesar de se acreditar neste dever moral; o que se sustenta é a possibilidade do homem assim proceder, como consectário de sua racionalidade, autonomia e liberdade, bem como de outros valores éticos consagrados em âmbito constitucional, tais como justiça e solidariedade.

Novamente parece faltar proporcionalidade em se suprimir a legitimidade individual para demandas coletivas a fim de garantir a segurança da coletividade, ou seja, para que ela não seja representada de modo frágil, pois faltará adequação ao alcance de tal fim, bem como necessidade de se suprimir uma liberdade individual de atuar em favor da coletividade.

Se a condução de um processo coletivo por uma parte hipossuficiente pudesse efetivamente apresentar riscos à coletividade, o mais adequado seria que o Estado

\footnotetext{
${ }^{258}$ Ibid., p. 41. Segundo os autores, o elevado custo processual não seria um problema para nenhum país da América Latina.

${ }^{259}$ Elton VENTURI. Processo civil coletivo: a tutela jurisdicional dos interesses difusos, coletivo e individuais ..., p. 136. O autor é enfático em defender tanto o papel do Estado moderno, de realizador dos direitos sociais, dentre eles o de acesso à justiça, como um discernimento do acesso à justiça, que abranja igualmente o acesso numa dimensão coletiva. Segundo ele: “[...], na medida em que o sistema processual brasileiro hoje disponibiliza não só a via individual, mas também a via coletiva, com o escopo de atuação dos direitos fundamentais, o acesso à justiça passa a ser garantido pela conjugação de ambas, na forma legalmente prevista, não sendo admissíveis, sob a ótica constitucional, restrições legislativas ou judiciais ao pleno desenvolvimento desse sistema".
} 
proporcionasse meios de superação dessas dificuldades ${ }^{260}$, não sendo adequado, simplesmente, impedir que o indivíduo litigue em demandas coletivas, mesmo porque, insista-se, existem associações com muito mais dificuldades do que alguns indivíduos isolados.

Por outro ângulo, ainda que se admitisse adequada tal medida, ela seria desnecessária, pois haveria outros meios de se garantir uma atuação robusta pelo legitimado ativo (muitos desses meios já mencionados no trabalho, como os poderes instrutórios, a gratuidade de justiça e a própria intervenção obrigatória do parquet), e de se abrandar os efeitos deletérios de uma má-representação (como a sistemática da coisa julgada secundumeventum litis ou probationis), sem a necessidade de se restringir a liberdade individual para atuar em favor da coletividade.

Conclui-se, portanto, que a legitimidade individual para demandas coletivas não pode ser obstada sob o argumento do risco da má representação individual poder prejudicar a condução de um processo coletivo, mormente quando se tem um órgão poderoso, que obrigatoriamente atuará no processo como fiscal da lei, não havendo proporcionalidade em tal argumento, que parecer ignorar o papel do Estado como realizador dos direito sociais e do acesso à justiça numa dimensão coletiva, como um direito fundamental.

\subsection{O risco de má representação pelo indivíduo e sua mitigação pelos poderes instrutórios do juiz}

Outra forma de se reduzir drasticamente o risco da má representação da coletividade pelo individuo, ocorre com o uso de amplos poderes instrutórios pelo juiz, de utilidade discutida nos processos individuais ${ }^{261}$, mas que no processo coletivo não costuma encontrar resistência ${ }^{262}$.

\footnotetext{
${ }^{260}$ Ibid., p. 136-137.

${ }^{261}$ Autores que estabelecem obstáculos ao uso dos poderes instrutórios nos processo individuais, com base na imparcialidade e na disponibilidade do direito privado, apesar de admiti-los excepcionalmente, em casos de direitos indisponíveis ou em caráter complementar: Hernando Devia ECHANDIA. Teoria general de laprueba judicial,p. 81. João Batista LOPES. Os poderes do juiz e o aprimoramento ...Revista de Processo, p. 37. Alguns autores, denominados de escola neoprivatista de processo, concebem os poderes instrutórios como uma afronta as garantias e liberdades processuais, um ato de autoritarismo do Estado, que não poderia intervir com tanto vigor na esfera de interesses privados, entretanto, eles não especificam qual garantia processual estaria sendo subvertida, numa aparentemente frágil importação do discurso garantista germinado
} 
Por meio dos poderes instrutórios, como é cediço, o juiz deverá produzir as provas necessárias ao conhecimento dos fatos alegados, quando as partes assim não procederem, evitando-se, com isto, a sentença que refuta uma versão fática pela ausência de provas, ao menos quando estas estiverem à sua disposição ${ }^{263}$.

Exemplo emblemático neste caso é o do juiz que determina a produção de prova pericial, mesmo sem requerimento da parte autora, em demanda onde se alega a ocorrência de danos incapacitantes e se pleiteia uma indenização.

No processo coletivo, pode-se imaginar a demanda versando sobre um dano ambiental, cuja prova pericial ou a exibição de documento ou coisa venha a ser determinada de ofício pelo juiz.

Nesse contexto, ajuizada uma demanda coletiva por um indivíduo que não tenha condições de contratar os melhores profissionais para atuar em defesa da coletividade, deverá o juiz ordenar a produção de toda e qualquer prova que esteja ao seu alcance e que seja necessária ao julgamento justo da causa.

Caso isso não ocorra, aí sim o juiz estará sendo parcial e protegendo a parte desonerada, pois estará beneficiando-a conscientemente em detrimento da parte onerada, sabendo da possível injustiça de sua decisão quanto ao mérito da questão, que poderia ser decidido de maneira diferente e mais conforme a desejada verdade, caso uma prova

no processo penal, mormente por LUIGI FERRAJOLI, que convive com uma realidade axiológica bem distinta do civil, já que no âmbito penal a dúvida deve beneficiar o réu, individuo, em detrimento do Estado. No âmbito civil esse raciocínio se mostra impertinente, pois não há uma parte mais frágil que deva ser beneficiada pela dúvida, ou seja, no processo civil a duvida não representa uma garantia do individuo contra a pretensão punitiva do Estado. Como representantes da escola neoprivatista pode ser citado: Franco CIPRIANI. El autoritarismo procesal (y laspruebasdocumentales). Revista IusetPraxis, versão on-line disponível em: www.scielo.cl/scielo.php?pid=S0718-00122007000200003\&script=sci_ar..., p. 4.

Nelcentenariodelregolamentodi Klein (Il processo civiletralibertà e autorità). RivistadiDirittoProcessuale,p. 983. Não obstante, LUIGI PAOLO COMOGLIO noticia que na Itália, a jurisprudência vem admitindo a atividade instrutória oficial, não com um caráter substitutivo, mas apenas suplementar: Luigi Paolo COMOGLIO. Le prove civili,p. 116-117.

${ }^{262}$ Nesse sentido: Marcelo ABELHA RODRIGUES. "A distribuição do ônus da prova no Anteprojeto do Código Brasileiro de Processos Coletivos."In: Ada Pellegrini GRINOVER;Aluisio Gonçalves de Castro MENDES;Kazuo WATANABE. Direito processual coletivo e o anteprojeto de Código Brasileiro de Processos Coletivos, p. 239-240.

${ }^{263}$ Em defesa dos poderes instrutórios: José Carlos BARBOSA MOREIRA. "A função social do processo civil moderno e o papel do juiz ..."Revista de Processo, p. 147. "Breves reflexiones sobre lainciviativa oficial ...”Temas de Direito Processual Civil,p. 37. "O juiz e a prova."Revista de Processo,p. 180. ___ . "A garantia do contraditório na atividade de instrução."Revista de Processo, p. 232. José Roberto dos Santos BEDAQUE. Poderes instrutórios do juiz, p. 154. Michele TARUFFO. "Poteriprobatoridelle parti e delgiudice in Europa."Rivistatrimestraledidiritto e proceduracivile,p. 452-458. Sobre a ausência de óbices decorrentes do princípio dispositivo: José Carlos BARBOSA MOREIRA. "O problema da divisão do trabalho entre juiz e partes ..."Revista de Processo,p. 11. Mauro CAPPELLETTI. "Iniciativa probatória deljuez ....'In: Oralidad y laspruebasenel processo civil,p. 122. 
relevante e pertinente, que já havia sido visualizada por ele como importante, mas que foi ignorada pela parte, tivesse sido produzida de ofício ${ }^{264}$.

O juiz que sabe que decidirá desfavoravelmente a uma parte, pela não produção de uma determinada prova, já vislumbrada por ele como necessária, mas olvidada pela parte, prova esta relevante e pertinente ao julgamento da causa, age com parcialidade, pois conscientemente beneficia alguém que ele não sabe se é a detentora da razão.

De outro lado, a determinação da produção da prova de ofício não quebra a imparcialidade, pois o juiz não sabe o resultado da prova antecipadamente ${ }^{265}$, sabe apenas que deve conhecer o máximo possível os fatos, para que a posterior aplicação da norma ao caso se dê adequadamente.

Aliás, mesmo que ele soubesse antecipadamente o resultado, seria completamente reprovável que ele se omitisse e decidisse de maneira contrária ao seu conhecimento, escondendo-se para tanto na omissão da parte.

Nesse cenário, caso a sentença julgue improcedente a pretensão coletiva com base na falta de provas, além da nulidade da decisão, caso a prova estivesse à disposição do juiz, como já defendemos outrora ${ }^{266}$, haverá, ainda, a possibilidade de repropositura da mesma ação coletiva com base na prova não utilizada ${ }^{267}$, conforme se verá no tópico seguinte, sem prejuízo, também, dos interesses individuais envolvidos.

Percebe-se assim, que a má representação consubstanciada na omissão instrutória da parte, desidiosa, propositadamente ou não, no seu ônus de demonstrar a veracidade dos fatos constitutivos do direito por ela alegado, não ensejará problema algum para a

\footnotetext{
${ }^{264}$ José Roberto dos Santos BEDAQUE. Poderes instrutórios do juiz, p. 108. O autor questiona: "não seria parcial o juiz, tendo conhecimento de que a produção de determinada prova possibilitará o esclarecimento de um fato obscuro, deixe de fazê-lo e, com tal atitude, acabe beneficiando a parte que não tem razão?"

${ }^{265}$ José Carlos BARBOSA MOREIRA. “O juiz e a prova."Revista de Processo,p. 180. No mesmo sentido: BEDAQUE, op. cit. p. 107, nota 264.

${ }^{266}$ Luciano Picoli GAGNO. Direito fundamental de acesso à justiça e técnicas de otimização da atividade e do juízo probatórios. p. 109. Nessa oportunidade sustentamos que: "Face a tais constatações, não há como se negar a ocorrência de nulidade processual, a ser sanada em segunda instância, caso o magistrado, ignorando o seu dever de aprimoramento da técnica processual e de oferecimento da melhor decisão possível, se mantenha inerte diante de uma alegação fática e rejeite os respectivos fatos por ausência de prova em sua decisão, não determinando a produção de um meio de prova que esteja ao seu alcance, ou seja, cuja fonte já tenha sido indicada pela parte ou por outros meio de prova, explicita ou implicitamente".

${ }^{267}$ Ada Pellegrini GRINOVER; Linda MULLENIX;KazuoWATANABE. Os processos coletivos nos países de civil law e common law: uma análise de direito comparado, p. 240 e 305. No mesmo sentido: Leslie Shérida FERRAZ; Marcos Paulo VERÍSSIMO. In:Susana Henriques da COSTA (Coord.). Comentários à lei de ação civil publica e lei de ação popular, p. 275 e 535-536.
} 
coletividade, em vista do dever que o juiz tem de produzir tais provas para proferir uma sentença coletiva justa.

Alguns poderiam destacar que o poder instrutório pode ser ignorado pelo juiz, que pode não se dar conta da possibilidade de produção oficial da prova, o que provocaria uma sentença de improcedência em desfavor da coletividade.

Em que pese nosso entendimento já manifestado outrora, sobre o fato do poder instrutório ser na verdade um dever, a ponto de tornar nula a sentença que, com base na ausência de provas, refute um fato alegado quando as provas estiverem à disposição do juiz, ainda que não houvesse nulidade alguma, não haveria nenhum prejuízo para a coletividade, pois a sentença lastreada na falta de prova não impedirá a propositura de uma nova ação coletiva idêntica, com os mesmos elementos da anterior, nem prejudicaria os indivíduos.

Conclui-se então, que além da participação do Ministério Público, a existência de poderes instrutórios por parte do juiz também contribui para minoração do risco da coletividade ser mau representada pelo indivíduo numa ação coletiva, risco este, que conforme se verá no tópico seguinte, resta ainda mais abrandado pela sistemática da coisa julgada nas ações coletivas.

\subsection{O risco de má representação pelo indivíduo e sua mitigação pelo regime da coisa julgada coletiva}

Indo por rumo complementar ao debate acima traçado, poderia se objetar contra a proposta de legitimidade individual para demandas coletivas, a possibilidade da má representação desempenhada pelo indivíduo acarretar prejuízos para a coletividade, decorrentes da suposta imutabilidade dos resultados desfavoráveis.

Naturalmente, poderia ser um risco grande para a coletividade, ter uma demanda sobre um bem indivisível ou um direito individual homogêneo, conduzida por um individuo comum, sujeito às instabilidades do espírito humano, a ponto de ser corrompido ou desestimulado pelos mais diversos fatores, em detrimento de todo o grupo representado no respectivo processo, causando resultados irreversíveis em desfavor da coletividade e dos membros que a compõem. 
Não à toa, nos Estados Unidos faz-se o controle da representatividade adequada, a fim de se evitar que uma demanda coletiva seja instaurada e conduzida por uma pessoa incapacitada - sob os mais diversos aspectos, para assim proceder ${ }^{268}$.

Contudo, tal receio não se mostra pertinente no ordenamento jurídico pátrio, não só por tudo que já foi dito nos tópicos anteriores, mas também em vista da sistemática da coisa julgada aqui adotada, bem diferente da adotada no modelo americano.

No Brasil, a coisa julgada produzida em um processo coletivo jamais poderá prejudicar direitos individuais daqueles que pertençam ao grupo, seja o objeto do processo indivisível - quando a coisa julgada só se estenderá as pretensões individuais in utilibus, seja ele divisível, mas homogêneo ${ }^{269}$.

${ }^{268}$ GRINOVER; MULLENIX; WATANABE, op. cit. p. 238, nota 266. Sobre a relação deste instituto com a coisa julgada, Grinover ensina que "esse pré-requisito - que diz respeito à seriedade, credibilidade, capacidade técnica e até econômica do legitimado à ação coletiva - é particularmente importante nos ordenamentos que escolhem a extensão a terceiros da coisa julgada, sem temperamentos; [...]”. Contribuindo para o discernimento do instituto: Suzana Henriques da COSTA. A representatividade adequada e litisconsórcio: o projeto de lei 5.139/2009. In: Petronio CALMON; Mirna CIANCI et al (Coord.). Em defesa de um novo sistema de processos coletivos: estudos em homenagem a Ada Pellegrini Grinover, p. 626. A autora ensina que: "O conceito de representatividade adequada surgiu no direito norte-americano. Trata-se de um dos requisitos para que uma demanda possa seguir como classaction e que corresponde à capacidade de a parte que litiga em nome da classe ou coletividade defendê-la de forma eficaz. O representante adequado, para o direito norte-americano, é aquela pessoa, membro da classe, que tem aptidão para satisfatoriamente fazer valer os interesses da coletividade perante a Corte". No mesmo sentido: Pedro da Silva DINAMARCO. Ação civil pública,p. 134-135. SUSANA HENRIQUES DA COSTA entende ainda, que no Brasil também ocorre o controle da representatividade adequada pelo juiz, quando o mesmo afere se há entre o autor da demanda "ligação teleológica com o interesse em jogo no processo ...", Ibid., p. 630-631. PEDRO DA SILVA DINAMARCO segue caminho diverso, falando que aqui a representatividade adequada é ope legis, Ibid., p. 201. De todo modo, todos os autores reconhecem o vinculo que há entre representatividade adequada e devido processo legal, pois sem aquela haveria grave violação ao acesso à justiça, em desfavor dos indivíduos que não participaram do processo coletivo, mas tenham sido afetados negativamente pela decisão.

${ }^{269}$ Ada Pellegrini GRINOVER; Nelson NERY JUNIOR;Kazuo WATANABEet al. Código Brasileiro de Defesa do Consumidor: comentado pelos autores do anteprojeto. 9. ed. p. 951-952 e 954. Segundo os autores: "Nos termos do disposto no $\S 1^{\circ}$ do art. 103, os efeitos da coisa julgada (ou a autoridade da sentença, na teoria de Liebman) não prejudicarão interesses e direitos individuais dos integrantes da coletividade, que poderão promover ações pessoais de natureza individual após a rejeição da demanda coletiva." E mais: "Mas na hipótese de improcedência da ação coletiva, as pessoas lesadas, que não tiverem participado da relação processual como litisconsortes do autor coletivo, ainda poderão propor ação indenizatória a titulo individual." Da mesma forma, em ações pseudoindividuais envolvendo bens indivisíveis, o sistema não admite resultado prejudicial a quem não foi parte, conforme dispõe o artigo 274 do Código Civil, apesar da doutrina moderna vir modificando seu pensar, para entender que terceiros podem ser afetados por decisões proferidas em ações pseudoindividuais, apenas no que concerne ao objeto indivisível destas, como já ocorre no processo coletivo envolvendo bens indivisíveis (difuso ou coletivo stricto sensu). Nesse sentido: Ada Pellegrini GRINOVER. Coisa julgada erga omnes, secundumeventum litis e secundumprobationem.Revista de Processo, p. 13-15. Precursor no Brasil do entendimento atual de ADA PELLEGRINI GRINOVER, ver: José Carlos BARBOSA MOREIRA. Litisconsórcio unitário,p. 26-27. Para o autor carioca, não há como se admitir a incompatibilidade prática ocorrida em caso de julgamentos contraditórios sobre objeto indivisível. Uma terceira via é trazida pelos professores MARCELO BONICIO e HEITOR SICA, que concluem pela eficácia erga omnes da sentença de improcedência envolvendo direito indivisível, pretendido pela via pseudoindividual, apenas quando a relação jurídica base já tenha nascido "envolvendo mais de duas pessoas", ou seja, apenas nos casos de direitos coletivos stricto sensu. Quando ela decorrer de um único ato de direito 
A chance de prejuízo, consistente numa decisão judicial transitada em julgado desfavoravelmente à coletividade, reduz-se às hipóteses dos direitos essencialmente coletivos, ou seja, difusos ou coletivos stricto sensu, quando uma decisão de improcedência sobre um bem indivisível poderá transitar em julgado, se não se fundar na insuficiência de provas, atingindo todos os codetentores do direito coletivo, no que se conhece como coisa julgada secundumeventumprobationis ${ }^{270}$ e se justifica pela indivisibilidade do objeto ${ }^{271}$.

Nesse contexto, um mau representante que, por exemplo, não recorresse de uma decisão teratológica de primeira instância, que julgasse improcedente demanda coletiva sobre um bem indivisível com base apenas no direito, sem utilizar-se, portanto, da regra do onusprobandi, poderia prejudicar a coletividade e, consequentemente, os indivíduos codetentores desse direito.

Tal risco, entretanto, é mitigado pela participação obrigatória do M.P., que é um ente legitimado expressamente pela lei, para ajuizar toda ação coletiva sem qualquer controle de representatividade, podendo fazer todas à vezes da parte autora, como visto, não só aditando a peça inicial, como interpondo recurso contra qualquer decisão, concluindo-se neste caso, que o possível prejuízo decorrerá não só da má-representação proporcionada pelo individuo, mas também pelo parquet, situação que não será resolvida nem se tomarmos por certo o rol restritivo de legitimados expressos para ação coletiva, já que nele insere-se, insista-se, aquele que obrigatoriamente deve participar de toda demanda coletiva, ou seja, o Ministério Público.

material, a partir do qual pessoas que não se consegue identificar se ligam de alguma forma, como no caso de direitos difusos, só haveria extensão para beneficiar. Nesse sentido: Marcelo José Magalhães BONICIO; Heitor Vitor Mendonça SICA. "Ensaio sobre os aspectos materiais e processuais do litisconsórcio unitário.”In: Aluisio Gonçalves de Castro MENEDES; Teresa Arruda Alvim WAMBIER. O processo em perspectiva: jornadas brasileiras de direito processual,p. 300-304. Para nós, conforme se esclarecerá mais adiante, a coisa julgada produzida em demanda pseudoindividual apenas será erga omnes se a demanda tiver sido convertida em coletiva, já que a autoridade erga omnes é própria do modelo coletivo de processo, da mesma forma que a restrição da coisa julgada às partes é própria do modelo individual.

${ }^{270}$ Ada Pellegrini GRINOVER. “Ações coletivas para a tutela do ambiente e dos consumidores - a lei 7.347, de 24.7.85."Revista de Processo, p. 117. Em sentido convergente: José Carlos BARBOSA MOREIRA. "A ação popular no direito brasileiro como instrumento de tutela jurisdicional dos chamados interesses difusos"”. Revista de Processo, p. 13. Elton VENTURI. Processo civil coletivo: a tutela jurisdicional dos interesses difusos, coletivo e individuais ..., p. 169. GRINOVER, NERY JUNIOR, WATANABE, op. cit. p. 929-930, nota 269.

${ }^{271}$ José Carlos BARBOSA MOREIRA. Litisconsórcio unitário,p. 26-27. 
O risco em menção, portanto, não decorre da legitimação individual para demandas coletivas, ou não apenas desta, mas da possível leniência do M.P. no exercício do seu papel, já destacado no tópico anterior.

Ainda assim, no que tange aos direitos individuais, ou seja, àqueles que pertençam exclusivamente a um único individuo, mesmo quando homogêneos, jamais poderão sofrer os efeitos deletérios da coisa julgada coletiva desfavorável, mesmo em se tratando de decisões proferidas em demandas sobre direitos indivisíveis, aos quais os direitos individuais estejam conexos (como por exemplo: indenização por dano material decorrente da poluição despejada no meio ambiente por uma indústria, tendo a ação ambiental para obter a interrupção da poluição sido julgada improcedente).

Nesses casos, a coisa julgada só repercutirá sobre direitos essencialmente individuais para beneficiar, no que se conhece como a extensão in utilibus da coisa julgada coletiva, discernida pela doutrina como uma ampliação objetiva da tutela coletiva ${ }^{272}$.

Nesse sentido, se a ação coletiva versar sobre direito individuais, mas homogêneos, com muito mais razão de ser a coisa julgada só poderá beneficiar os titulares dos direitos individuais representados.

Tal situação, relacionada à coisa julgada secundumeventum litis, é alvo de diversas críticas por parte daqueles que entendem haver uma desigualdade no tratamento da parte autora de uma ação coletiva em detrimento da parte ré, individual, que jamais terá uma coisa julgada produzida num processo coletivo, que a livre por completo de uma possível decisão diferente sobre o mesmo assunto, numa dimensão individualizada do processo e do seu objeto ${ }^{273}$.

Nos Estados Unidos, a coisa julgada pode tanto prejudicar como beneficiar a coletividade e os direitos individuais daqueles que pertencentes a ela, tanto no que se refere

\footnotetext{
${ }^{272}$ Ada Pellegrini GRINOVER. Coisa julgada erga omnes, secundumeventum litis $e$ secundumprobationem.Revista de Processo, p. 20.

${ }^{273}$ José Rogério Cruz e TUCCI. Código do Consumidor e processo civil: aspectos polêmicos. Revista dos tribunais,p. 37. Além do autor, pode-se consultar também JOSÉ IGNACIOBOTELHO MESQUITA, amplamente citado pelo primeiro. A professora ADA PELLEGRINI GRINOVER ensina que autores italianos como VIGORITI e LUISO, chamam atenção para o desequilíbrio em relação à defesa, bem como para o risco de julgados pragmaticamente contraditórios, no que são acompanhados pelas lições do professor carioca JOSÉ CARLOS BARBOSA MOREIRA. Não obstante, na mesma Itália, autores como ALLORIO, PUGLIESE e CARPI defendem a coisa julgada secundumeventum litis. Sobre o assunto, consultar os seguintes autores, que defenderam a sistemática pátria, com base no contraditório, na ampla defesa e no devido processo legal: Ada Pellegrini GRINOVER; Nelson NERY JÚNIOR;Kazuo WATANABEet al. Código Brasileiro de Defesa do Consumidor: comentado pelos autores do anteprojeto, 9. ed.p. 928-931. LENZA, Pedro. Teoria Geral da Ação Civil Pública, p. 255-260.
} 
aos direitos essencialmente coletivos, como no que se refere aos direitos individuais homogêneos, diferentemente do que ocorre aqui; isto por conta do sistema de opt out que lá predomina para os casos de classactions for damages $^{274}$.

Nesse sistema, caso a demanda envolva bem indivisível, não há escolha, o resultado afetará tanto a coletividade como os seus indivíduos, seja qual for o resultado ${ }^{275}$; caso a demanda envolva direitos ou bens divisíveis, mas homogêneos, aí serão afetados apenas os que não se manifestarem pela sua exclusão, ou seja, serão realizados atos de informação no processo $^{276}$, visando à informação de todos os indivíduos que possam se interessar; aqueles que se mantiverem silentes, não comparecendo ao processo para pedir sua exclusão, serão abrangidos pelos efeitos da decisão e pela imutabilidade da coisa julgada.

Esse sistema é repetido em diversos países, principalmente baseados no common law, sendo menos comum na Europa continental, onde é preferido o seu extremo oposto, denominado de opt $i^{277}$, ou seja, as pessoas se manifestam para concordarem em ser afetadas pela coisa julgada.

Alguns países ainda mesclam os dois métodos, não no mesmo processo obviamente, pois eles se excluem mutuamente, mas estabelecendo o opt out para algumas hipóteses e o opt in para outras ${ }^{278}$.

O sistema brasileiro, denominado de coisa julgada secundumeventum litis, preferido pelos países Ibero-americanos (com exceção de Portugal, Colômbia e a província argentina

\footnotetext{
${ }^{274}$ Ibid., p. 37 (TUCCI). O autor explica que o modelo de coisa julgada secundumeventum litis vigorou também nos Estados Unidos, até a reforma legislativa de 1966, que atribuiu ao juiz o papel de examinar a adequação da representatividade desempenhada pelo autor, além de impor "a notificação, pessoal ou por edital, de todos os integrantes do grupo, para que, dentro de um prazo razoável, venham, se o desejarem, exercer, no processo, direito de auto-exclusão, vale dizer, a manifestação de vontade de não ser atingido pelos efeitos da sentença transitada em julgado."

${ }^{275}$ Humberto Dalla Bernardina de PINHO. A natureza jurídica do direito individual homogêneo e sua tutela pelo Ministério Público como forma de acesso à justiça,p. 138, 144, 150-151. No mesmo sentido: Ada Pellegrini GRINOVER; Linda MULLENIX;Kazuo WATANABE,Os processos coletivos nos países de civil law e common law: uma análise de direito comparado, p. 240 e 307.

${ }^{276}$ Ibid., p. 141-142 (PINHO). Neste ponto, o autor traz à baila caso concreto em que a notificação individualizada, exigida pela literalidade da Regra 23 e ratificada pela Suprema Corte, prejudicou os resultados de ação coletiva envolvendo mais de duas milhões de pessoas.

${ }^{277}$ Ada Pellegrini GRINOVER; Linda MULLENIX;Kazuo WATANABE. Os processos coletivos nos países de civil law e common law: uma análise de direito comparado, p. 242-243 e 304. Segundo os autores ADA PELLEGRINI GRINOVER e KAZUO WATANABE, países como Alemanha, França, Itália e Suécia preferem o opt in. Apenas Holanda, Portugal e um dos Projetos da Itália utilizam-se do sistema opt out.

${ }^{278}$ Ibid., p. 243 e 304-305. Países como Israel, Noruega, Suécia e o Projeto da Dinamarca, aderem ao critério opt in, mas utilizam o critério opt out para hipóteses residuais, de baixo valor econômico, nos quais é diminuto o interesse de intervenção.
} 
de Catamarca ${ }^{279}$,só permite que o direito individual seja afetado pela coisa julgada coletiva, se for para beneficiá-lo; caso o resultado tenha sido contrário aos interesses individuais, seus respectivos indivíduos terão a possibilidade de obter um julgamento sobre o mérito da sua causa específica, pela via individual.

No plano das ações coletivas, a ação julgada improcedente não impedirá a propositura de outra ação coletiva idêntica por qualquer parte, ou ate mesmo de ações pseudoindividuais ${ }^{280}$, se a improcedência decorrer de falta de provas ${ }^{281}$, técnica conhecida por coisa julgada secundumeventumprobationise que evita em parte prejuízos à coletividade e aos entes expressamente legitimados ao uso da demanda coletiva ${ }^{282}$.

Por outro lado, no mesmo plano coletivo, se a sentença coletiva de improcedência estiver fundada nas provas ou apenas no direito, impedirá tanto o ajuizamento de ações coletivas com o mesmo objeto, como de ações pseudoindividuais com o mesmo objeto ${ }^{283}$, ficando resguardada, por obvio, as ações individuais, ainda que de alguma forma ligadas

${ }^{279}$ Ibid., p. 243-245 e 305-306.

${ }^{280}$ Sobre a relação entre demandas individuais e coletivas, que dá origem ao termo ações pseudoindividuais: KazuoWATANABE. Relação entre demanda coletiva e demandas individuais. In: Ada Pellegrini GRINOVER; Aluisio Gonçalves de Castro MENDES; KazuoWATANABE. Direito processual coletivo e o anteprojeto de Código Brasileiro de Processos Coletivos, p. 156. No mesmo sentido: Marcelo José Magalhaes BONICIO; Heitor Vitor Mendonça SICA. "Ensaio sobre os aspectos materiais e processuais do litisconsórcio unitário.”In: Aluisio Gonçalves de Castro MENEDES; Teresa Arruda Alvim WAMBIER. $O$ processo em perspectiva: jornadas brasileiras de direito processual, p. 285.

281 Apesar dos autores refutarem a coisa julgada secundumeventumprobationis para demandas coletivas envolvendo direitos individuais homogêneos, pela suposta ausência de previsão legal, parece-nos que o melhor entendimento é aquele que interpreta as normas relativas à coisa julgada coletiva numa ótica sistemática, por meio da qual, eventuais lacunas sejam internamente supridas. Nesse caso, por uma questão de coerência sistemática, no plano das ações coletivas pensamos que a coisa julgada será sempre sencudumeventumprobationis, e no plano individual, sempre secundumeventum litis. Para exemplificar como pensa a doutrina pátria: Ada Pelegrini GRINOVER; Nelson NERY JÚNIOR;Kazuo WATANABE et al. Código Brasileiro de Defesa do Consumidor: comentado pelos autores do anteprojeto, 9.ed. p. 930. GRINOVER; MULLENIX; WATANABE, op. cit. p. 243 e 306, nota 276. Pedro LENZA. Teoria Geral da Ação Civil Pública, p. 235.

${ }^{282}$ Ada Pellegrini GRINOVER. “Ações coletivas para a tutela do ambiente e dos consumidores - a lei 7.347, de 24.7.85."Revista de Processo, p. 117. Em sentido convergente: José Carlos BARBOSA MOREIRA. A ação popular no direito brasileiro como instrumento de tutela jurisdicional dos chamados "interesses difusos”. Revista de Processo, p. 13. Elton VENTURI. Processo civil coletivo: a tutela jurisdicional dos interesses difusos, coletivo e individuais ..., p. 169. GRINOVER, NERY JUNIOR, WATANABE, op. cit. p. 929-930, nota 281.

${ }^{283}$ Marcelo José Magalhaes BONICIO; Heitor Vitor Mendonça SICA. "Ensaio sobre os aspectos materiais e processuais do litisconsórcio unitário.”In: Aluisio Gonçalves de Castro MENEDES; Teresa Arruda Alvim WAMBIER. O processo em perspectiva: jornadas brasileiras de direito processual, p. 293 e 296. 
ou conexas a direito indivisível julgado em sentença coletiva, já que esta estende seus efeitos apenas para beneficiar as pretensões essencialmente individuais ${ }^{284}$.

Destaca-se no ensejo, que mesmo assim, a má-representação desempenhada por um individuo isoladamente numa ação essencialmente coletiva, ou seja, sobre objeto indivisível, não terá o condão de prejudicar outros indivíduos no que tange ao direito coletivo do qual seriam codetentores, insista-se, pois o M.P. participará obrigatoriamente da lide, cabendo a ele, como ente expressamente legitimado que é, desempenhar as mesmas funções do autor da ação, como visto no tópico acima.

Se o parquet também não proceder adequadamente, então o problema não será exclusivamente da legitimidade individual para ações coletivas, mas sim de representatividade adequada, independentemente do ente legitimado e, portanto, já será passível de ocorrer na sistemática atual, em que o individuo não se encontra expressamente legitimado para todo tipo de ação coletiva.

Dessa maneira, questiona-se, se a coisa julgada coletiva nunca prejudicará direitos individuais, e nem agrava o risco já existente sobre os direitos essencialmente coletivos, como justificar a ausência de legitimidade individual para demandas coletivas, com base no suposto risco de uma eventual má representação gerar resultados prejudiciais à coletividade e aos indivíduos componentes do grupo?

Aparentemente sem sentido, portanto, se mostra esse argumento no âmbito do nosso ordenamento jurídico; nos países com sistemas baseados em outros métodos também, tendo-se em vista a possibilidade de manifestação pela exclusão ou pela inclusão.

Repita-se apenas, que alguém poderia até suscitar, que a má representação desempenhada por um indivíduo pode gerar prejuízos à coletividade e aos indivíduos codetentores de direitos indivisíveis, na medida em que poderia impedir novas demandas

\footnotetext{
${ }^{284}$ Ada Pellegrini GRINOVER. Coisa julgada erga omnes, secundumeventum litis $e$ secundumprobationem.Revista de Processo, p. 20. Para contribuir, a autora cita o seguinte exemplo, demonstrando como uma demanda essencialmente coletiva pode trazer benefícios essencialmente individuais: "Exemplificando, se a ação ambiental em defesa de interesses difusos levou a uma sentença que reconheceu a existência de dano e condenou a sua reconstituição, as pessoas que sofreram prejuízos pessoais em decorrência do mesmo dano ambiental não precisarão ajuizar ações de conhecimento de índole reparatória, mas bastará que procedam à liquidação, quantificando os danos individuais e provando o nexo etiológico entre estes e o dano ambiental geral reconhecido pela sentença coletiva". Se a sentença do exemplo fosse de improcedência com base nas provas, impediria apenas novas ações coletivas ambientais cujo objeto era difuso, ou pseudoindividuais com o mesmo objeto, mas nunca impediria ações individuais reparatórias, ainda que tais pretensões fossem conexas ao dano ambiental refutado na referida sentença.
} 
coletivas idênticas ou até ações pseudoindividuais, por meio das quais o individuo consiga relacionar a sua esfera jurídica individual com um bem coletivo.

Nesse ponto, deve-se registrar insistentemente, que a ação coletiva ou a pseudoindividual poderá sempre ser reproposta, quando a sentença coletiva for de improcedência por falta de provas, o que, insista-se, é conhecido por coisa julgada secundumeventumprobationis ${ }^{285}$.

Com essa técnica, não há o risco de um comportamento desidioso ou malicioso da parte, no que tange à prova dos fatos, desaguar numa imutabilidade absoluta de uma decisão de mérito de improcedência ${ }^{286}$.

Além do mais, estando em companhia do Ministério Público, se prejuízo houver não será pela simples leniência do individuo, mas também do parquet, que sendo um legitimado expressamente reconhecido pelas leis atuais, livre de qualquer controle de representatividade, já proporciona o risco de prejuízo em questão, à coletividade e aos indivíduos nos direitos indivisíveis compartilhados, quando a demanda for ajuizada pelo próprio M.P.

Pode-se concluir, portanto, pela aparente improcedência do argumento que defende a ausência de legitimidade individual para demandas coletivas, com base no suposto risco de obtenção de resultados desfavoráveis.

Mesmo que o indivíduo, muitas vezes não proporcione a melhor atuação no processo coletivo, ainda assim é melhor que ele possa atuar, sendo efetivamente livre e participativo no Estado Democrático de Direito, do que se restringir essa participação, sob o falso pretexto dela gerar riscos inconsistentes ou já existentes, mas que em nada serão aumentados.

\footnotetext{
${ }^{285}$ GRINOVER, op. cit. p. 117, nota 282. Em sentido convergente: BARBOSA MOREIRA, op. cit. p. 13, nota 282. VENTURI, op. cit. p. 169, nota 282.

${ }^{286}$ GRINOVER, MULLENIX, WATANABE, op. cit. p. 241, nota 277. Segundo Grinover: "Essa regra, contra a qual se insurge o relator de Portugal por considerá-la contrária ao princípio da igualdade das partes, encontra origem na lei brasileira sobre Ação Popular, de 1965, e é aplaudida pela doutrina como uma salvaguarda eficaz contra a possível colusão entre demandante e demandado, que poderiam almejar uma coisa julgada erga omnes desfavorável ao autor popular, atingida pela via de uma atividade probatória insuficiente. Aliás, o próprio relator português admite que, nesse caso, a previsão é útil, verberando apenas sua generalização". Em sentido convergente: GRINOVER, NERY JÚNIOR, WATANABE, op. cit. p. 929930, nota 281.
} 


\subsection{A ação penal privada subsidiária da pública e sua relação com a legitimidade individual para demandas coletivas}

No âmbito do direito processual penal existem as ações penais públicas e as ações penais privadas, o que irá variar conforme o crime praticado, sendo certo, que a regra é a propositura de ação penal pública ${ }^{287}$, baseada no interesse público subjacente à aplicação da pena nos respectivos $\operatorname{casos}^{288}$.

O legitimado expressamente previsto em lei para a propositura de uma ação penal pública é o Ministério Público ${ }^{289}$, que será o titular da ação penal; não obstante, caso o parquet não realize o seu mister no prazo legal, poderá o particular assim proceder, constituindo tal norma uma cláusula pétrea e um direito fundamental do indivíduo, insculpido no artigo $5^{\circ}$, LIX da CRFB ${ }^{290}$.

Percebe-se aí, uma hipótese legal em que o indivíduo terá legitimidade extraordinária para representar o Estado e buscar a aplicação da pena em desfavor do culpado por um delito ${ }^{291}$.

Nessa situação, tem-se um típico caso de legitimação individual para demanda pública $^{292}$, assumindo o indivíduo o papel de guardião da sociedade, uma vez que a lei

\footnotetext{
${ }^{287}$ Paulo RANGEL. Direito processual penal,p. 216. Segundo o autor: "A regra é que toda ação penal é pública (cf. art. 100 do CP), porém, excepcionalmente, o legislador (por isso exceção) legitima o particular a propor ação, surgindo, assim, a ação penal de iniciativa privada".

${ }^{288}$ José FREDERICO MARQUES. Elementos de direito processual penal, p. 394. Pondera o autor, contudo, a necessidade de também haver hipóteses de ação privada, pois: "O interesse público em que se funda o direito de punir do Estado não pode, em determinados casos, sufocar os interesses de caráter privado que a norma penal também tutela".

${ }^{289}$ Eugenio PACELLI DE OLIVEIRA. Curso de processo penal,p. 103. No mesmo sentido: RANGEL, op. cit. p. 215-216, nota 287.

${ }^{290}$ Ibid. p. 161 (PACELLI). Segundo o autor: "Ocorre que a Constituição da República institui,como garantia fundamental, o oferecimento da ação penal privada subsidiária, conforme o disposto no seu art. $5^{\circ}$, LIX". Outrossim, o professor PAULO RANGEL identifica intimo contato entre a norma retro mencionada e o inciso XXXV do mesmo artigo $5^{\circ}$, que estabelece o principio da inafastabilidade da tutela jurisdicional, conforme RANGEL, op. cit. p. 288, nota 287.

${ }^{291}$ FREDERICO MARQUES, op. cit. p. 287. Neste caso, o autor paulista ensina que: "Como o Estado é o único titular do direito de punir, o ofendido ou querelante, na ação penal privada, não invoca nenhum direito material seu. A pretensão punitiva deduzida em juízo tem no Estado seu titular, pelo que este transfere ao ofendido tão-só o direito de acusar".

${ }^{292}$ PACELLI DE OLIVEIRA, op. cit. p. 160, nota 289. O fato do querelante ser um particular, não torna a ação privada.
} 
penal tem o escopo de proporcionar segurança a todos que vivem sob a autoridade de um Estado $^{293}$.

Nesse horizonte, surge a questão: se o individuo pode ser autor, ainda que subsidiariamente, de ação penal que deveria ser pública, pelo crime praticado, por que não poderia ser autor de ação civil, igualmente pública?

E mais: se a ação penal privada subsidiaria da pública é um direito fundamental do indivíduo, não deveria ser assim considerada também a ação civil pública, já que em ambos os casos tem-se a atuação do individuo não para a satisfação de um interesse privado, mas sim de um interesse público e um fim social?

O que difere a ação penal pública da ação civil pública é somente o objeto da ação, já que em uma se tem por objeto a aplicação de uma pena e noutra se busca a tutela de um bem coletivo ou coletivamente tratado ${ }^{294}$.

Contudo, tal diferença não parece ser suficiente para justificar o tratamento desigual no plano da legitimidade, já que não torna a tutela penal mais importante que a cível ou vice e versa.

Em contrapartida, como ponto em comum, pode-se dizer que o objetivo mirado ao se garantir a ação penal privada subsidiaria da pública, de atuação da ordem jurídica, garantia da autoridade estatal e da liberdade dos indivíduos, também será proporcionado com a ação civil pública, onde um indivíduo, mesmo não sendo o único titular do bem, atua em favor da sociedade e da ordem jurídica, primando pela sua observância e, consequentemente, pela manutenção da autoridade estatal, da segurança e da liberdade das pessoas, já que ninguém pode se dizer verdadeiramente livre se não tiver seus direitos respeitados.

Numa compreensão teleológica da norma que legitima o particular para a ação penal pública subsidiariamente, nota-se a relevância social do direito penal e o objetivo de se impedir que eventuais desvios de conduta por parte do principal legitimado, o parquet,

\footnotetext{
${ }^{293}$ Eugenio Raúl ZAFFARONI. Tratado de derecho penal: parte general, p. 43-44. "El derechotiene por funcion possibilitar la existência, lo que implica assegurar laco-existencia, porque la existência humana siempre -e ineludiblemente- es co-existencia. Este aseguramiento se obtieneintroduciendounorden coactivo que impidala guerra civil, esto es, la guerra de todos contra todos."

${ }^{294}$ Candido Rangel DINAMARCO. Fundamentos do processo civil moderno,p. 306 e 322 . O autor ensina que objeto se confunde com mérito e que este, outra coisa não é senão aquilo que a parte pretende obter com a demanda, o pedido. No demanda penal pede-se a aplicação de uma pena, na civil a proteção de um bem jurídico.
} 
obstruam a sua aplicação, preocupação que merece ser estendida ao âmbito cível, para os casos de direitos coletivos lato sensu, pois, além de sua relevância social inconteste, estes por vezes são relegados pelos entes expressamente legitimados pela lei. Não se justifica a outorga de maior importância ao direito penal.

Se o individuo tem o direito fundamental de obter a aplicação do direito penal num caso em que tenha sido vitima de um crime, mesmo não cabendo a ele o direito de punir, que é do Estado ${ }^{295}$, mostra-se natural que o individuo tenha o direito fundamental de obter a proteção coletiva de um direito indivisível ou divisível, mas homogêneo, num caso em que tenha o interesse próprio também envolvido.

Nota-se, que em ambos os casos se tem a busca pela tutela de um direito que não pertence ao individuo, ou não pertence exclusivamente a ele, pois no direito penal a vitima não tem o direito de punir seu algoz, cabendo-o ao Estado ${ }^{296}$, e no direito coletivo haverá uma indivisibilidade ou homogeneidade que permite ao direito transcender a individualidade.

Sob esse prisma, se o acesso à justiça, para que se tenha a aplicação de uma pena ao culpado por um crime, constitui um direito fundamental do individuo, mesmo este não tendo direito material algum, por se partir da premissa que o direito penal é socialmente relevante, o acesso para que se tenha a proteção de um bem indivisível, ou divisível, mas homogêneo, também poderá ser considerado, já que em ambos os casos se tem a violação à ordem jurídica, de modo a atingir direitos indisponíveis ou bens de relevância social, afrontando a segurança e a liberdade de um grupo de pessoas, e criando uma desconfiança na capacidade do Estado resolver os conflitos eclodidos sob a sua soberania.

Mesmo nos casos envolvendo direito individuais homogêneos, ainda que individualmente o direito possa ser considerado disponível, aparentando justificar uma restrição na legitimidade individual, tem-se que ele se torna indisponível e de relevância social quando homogêneo, ou seja, capaz de ser tratado coletivamente, de modo, aliás, a

\footnotetext{
${ }^{295}$ Afrânio SILVA JARDIM. Ação penal pública: princípio da obrigatoriedade, p. 13. Segundo o autor carioca: "É de todos sabido que a aplicação de uma determinada sanção penal não está voltada para a satisfação retributiva da vítima, embora se possa reconhecer como natural a sua vontade de ver punido o agressor. A pena não tem a função de reparar o dano causado, não tem caráter reparatório". No mesmo sentido: FREDERICO MARQUES, op. cit. p. 393, nota 291.

${ }^{296}$ Ibid., p. 15 (SILVA JARDIM).
} 
justificar a legitimidade do parquet para tais demandas ${ }^{297}$, mesmo porque, o trato coletivo de tais questões repercute em outros valores essenciais ao Estado Democrático de Direito, tais como justiça e eficiência no acesso à justiça, dentro de um prazo razoável ${ }^{298}$.

Ainda que determinado direito não seja indisponível, o direito a sua satisfação da maneira mais rápida, eficiente e abrangente o $e^{299}$, e isto pressupõe o uso do processo coletivo, não havendo justificativa para se restringir seu uso apenas aos casos de direito indisponível, muito pelo contrário, as razões que existem conduzem no sentido de se estender ao máximo possível o uso do processo coletivo.

Destaca-se no ensejo, que na esfera penal, a outorga de legitimidade extraordinária ao individuo é muito mais arriscada, já que a sistemática da coisa julgada não terá como proteger o substituído em detrimento do direito fundamental de liberdade do acusado, ou seja, se este for absolvido, independentemente do motivo, aquela ação penal não poderá ser reproposta, o que acaba por justificar a subsidiariedade da legitimidade individual, sem que tal limitação possa ser importada para o âmbito cível.

Conclui-se assim, pela existência de relação entre a legitimidade individual para ação penal privada subsidiária da pública e a legitimidade individual para demandas coletivas, de modo que a positividade da primeira possa subsidiar a defesa da segunda, mormente quando, sendo um direito fundamental do individuo, permite classificar essa segunda também como um direito fundamental, ante a identidade ontológica entre tais instrumentos, que na essência constituem um mecanismo único, para permitir que o indivíduo tenha meios de proteger bens relevantes socialmente, coletivos ou homogêneos,

${ }^{297}$ Tanto o STF como o STJ vem manifestando entendimentos favoráveis pela legitimidade do Ministério Público, para pleitear a tutela de direitos individuais homogêneos. Neste sentido: AgRg no AI 516.419/PR, 2a Turma do Supremo Tribunal Federal, Rel. Min. Gilmar Mendes, DJe de 30/11/2010; REsp 797963/GO, Recurso Especial 2005/0189670-8, Rel. Min. Nancy Andrighi, $3^{\text {a }}$ Turma do Superior Tribunal de Justiça, DJe de 05/03/2008. No primeiro excerto, o Min. Gilmar Mendes entende que a legitimidade do parquet fica restrita aos direito individuais homogêneos com relevância social, ao contrário da decisão da Min. Nancy Andrighi, que entende pela relevância social estar intrínseca em toda hipótese de direito individual homogêneo.

${ }^{298}$ Candido Rangel DINAMARCO. Fundamentos do processo civil moderno,p. 210. Aqui o autor justifica a inclusão da razoável duração como cláusula constitucional, salientando algumas medidas pragmáticas com o condão de atendê-la, adotadas pela reforma do Judiciário.

${ }^{299}$ Candido Rangel DINAMARCO. A instrumentalidade do processo,p. 70-74. Conforme o autor: "Evidentemente, não é apenas nesses pontos que se mostra o caráter público do processo. Sua natureza instrumental impõe que todo o sistema processual seja permeado dessa conotação, para que realmente apareça e funcione como instrumento do Estado para a realização de certos objetivos por ele traçados; com o aspecto ético do processo não se compadece o seu abandono à sorte que as partes lhe derem, ou uma delas em detrimento da mais fraca, pois isso desvirtuaria os resultados do exercício de uma atividade puramente estatal e pública, que é a jurisdição." 
sem que tal proteção fique condicionada ao arbítrio de um órgão ou das pessoas que o compõem.

Por fim, registra-se que a própria Constituição afirma que os direitos fundamentais não se resumem àqueles expressamente previstos no seu artigo $5^{\circ}$, devendo ser plena $\mathrm{e}$ imediatamente satisfeitos, ainda que inexista previsão legal em tal sentido.

\subsection{A legitimidade individual para a ação popular e sua extensão para os demais campos da tutela coletiva}

Para a propositura de uma ação popular, tanto a constituição federal como a lei específica garantem ao cidadão legitimidade para individualmente demandar sobre objetos $\operatorname{difusos}^{300}$, quais sejam: o patrimônio público, a moralidade administrativa, o meio ambiente, além de outros, trazidos pelo Diploma Político de 1988.

Aliás, a Constituição Federal coloca a legitimidade para a ação popular, assim como para a ação penal privada subsidiária da pública, como um direito fundamental do indivíduo, impossível de ser suprimido pela via derivada, constituindo assim, elemento fundamental da democracia participativa pertinente ao atual Estado Democrático de Direito $^{301}$.

Por esse rumo, em consonância com o exposto acima, devemos nos questionar: por que apenas haveria legitimidade individual para a propositura de ação popular, e não para as demais ações coletivas? Que diferença faz que a lesão tenha sido cometida por meio de um ato público ou privado? Seria razoável restringirmos o acesso à tutela coletiva apenas para proteção dos direitos difusos violados ou ameaçados por atos da administração pública ou de entes específicos?

\footnotetext{
${ }^{300}$ José Carlos BARBOSA MOREIRA. “A ação popular no direito brasileiro como instrumento de tutela jurisdicional dos chamados "interesses difusos"'. Revista de Processo, p. 9. Em seu trabalho, o autor carioca explica que não pretende discutir aspectos ligados à essência ou à definição dos direito difusos, "mas apenas oferecer à consideração dos especialistas alguns dados referentes a um instrumento que, dentro de certos limites, pode servir e tem servido a esse fim no Direito Brasileiro.”, qual seja: à proteção dos direitos difusos.

${ }^{301}$ José AFONSO DA SILVA. "O sistema representativo, democracia semidireta e democracia participativa."Revista do Advogado, p. 103. Segundo JOSÉ AFONSO DA SILVA: “A ação popular, enfim, constitui um instituto de democracia participativa, e o cidadão, que a intenta, fá-lo em nome próprio, por direito próprio, na defesa de direito próprio, que é o de sua participação na vida política do Estado, fiscalizando a gestão do patrimônio público e dos interesses difusos.”
} 
O fato de se tratar de ação originariamente reduzida à proteção do patrimônio público $^{302}$ não parece justificar tal restrição, mesmo porque a constituição amplia o uso dessa ação para a proteção do meio ambiente e do patrimônio histórico e cultural, o que, aliás, a doutrina ensina que, de certa forma, já havia sido feito pela lei infraconstitucional e por alguns posicionamentos jurisdicionais isolados, que estenderam sabiamente o significado do termo patrimônio para além de pecúnia ${ }^{303}$.

Com essa ampliação, parece que o objetivo do constituinte foi, seguindo com maior vigor a tendência inaugurada pelo legislador ordinário e pelos tribunais, o de ampliar o uso dessa ação, para toda hipótese em que houver alegada violação a um direito difuso, pois sendo difuso, o bem tutelado será público, ou seja, não pertencerá a determinados indivíduos, e terá igual relevância, independentemente de sua natureza, o que significa dizer que não há uma escala racional, que nos permita graduar certos direitos difusos como mais importantes que outros, a ponto de restringirmos a legitimidade individual para alguns apenas.

Por mais que o ato lesivo praticado pelo próprio Estado, ou pelos seus agentes, seja mais hediondo e, indiscutivelmente, mais nocivo ao modelo democrático de direito, é certo também que para a vítima, direito lesado é direito lesado, tenha essa lesão sido causada pelo Estado e seus agentes, ou só por um particular.

E tanto legislador como constituinte colocaram no mesmo patamar a importância do erário, do meio ambiente e dos bens de valores históricos, culturais ou estéticos, não havendo meios de se defender com razoabilidade, uma concepção míope dessa ação constitucional, que entenda que apenas alguns direitos difusos podem ser tutelados em procedimento de iniciativa cidadã, ou seja, pela via da ação popular .

Portanto, a justificativa originária para a ação popular, de que todos têm de ter legitimidade para fiscalizar a coisa pública, com o poder de controle de tais atos, já que

\footnotetext{
${ }^{302}$ José AFONSO DA SILVA. Ação popular constitucional: doutrina e processo,p. 38-39. No mesmo sentido: Rodolfo de Camargo MANCUSO. Ação Popular,p. 61-65.

${ }^{303}$ BARBOSA MOREIRA, op. cit. p. 10-11, nota 300. O autor carioca traz um exemplo em que o Tribunal mineiro estendeu o significado da disposição legal sobre ação popular, a fim de tutelar situação relacionada ao nível qualitativo da vida da população.
} 
todos são seus codetentores ${ }^{304}$, estende-se a todos os bens difusos, ou seja, que pertençam em alguma medida a todas as pessoas relacionadas por alguma circunstância fática ${ }^{305}$.

Esse contexto, portanto, parece consagrar a possibilidade do individuo buscar a tutela de outros direitos difusos, ainda que não decorram de violação consubstanciada em ato administrativo, ou que não estejam expressamente previstos no rol da Lei de Ação Popular, a nosso ver exemplificativo, por se tratar de norma garantidora de direitos fundamentais individuais, que não se esgotam nas hipóteses abstratas insculpidas nos diplomas, conforme dispõe a própria Constituição, ou seja, permitem resultados extensivos na sua compreensão, desde que para ampliar ou favorecer a proteção dos direitos fundamentais $^{306}$.

Da mesma forma, o fato do réu ser um ente privado, totalmente desvinculado da administração pública e de seus atos, também não representaria uma diferença ontológica capaz de justificar a legitimidade individual apenas para a ação popular no sistema, pois, insista-se, direito lesado é direito lesado, não havendo como se graduar um direito difuso em face do outro, ainda que se leve em conta se o autor da lesão era uma entidade pública, um agente público ou um simples particular isolado.

O que se quer dizer, é que não aparenta haver racionalidade em se autorizar o individuo demandar em prol de bem difusos, somente quando se inserir no rol de responsáveis pela lesão um ente público ou seus agentes, autores de ato administrativo que lhe cause lesão, pois tanto neste caso como nos outros, a qualidade do bem justificaria a legitimação individual para agir, não havendo diferença em que o direito tenha sido lesado por A ou B.

Percebe-se assim, que uma interpretação teleológica do texto constitucional e do sistema infraconstitucional, nos permite afirmar com serenidade, que o individuo possui legitimidade para demandar a proteção de qualquer direito difuso, com amparo na ação popular, pelas razões elencadas, de igualdade de importância entre tais bens e indiferença com relação à natureza jurídica do ato ou da autoridade responsável pela lesão.

\footnotetext{
${ }^{304}$ AFONSO DA SILVA, op. cit. p. 19, nota 302.

${ }^{305}$ Ada Pellegrini GRINOVER. "Ações coletivas para a tutela do ambiente e dos consumidores - a lei 7.347, de 24.7.85." Revista de Processo, p. 114. A autora define o que são os direitos difusos, com base na existência de algum fato que atribua a todos os indivíduos por ele abrangidos, interesse na proteção de um bem indivisível.

${ }^{306}$ Ingo Wolfgang SARLET. A eficácia dos direitos fundamentais: uma teoria geral dos direitos fundamentais ..., p. 81 .
} 
A ideia é que a tutela de tais direitos jamais fique em lugar inalcançável pelo cidadão, seu codetentor, que não pode ter a proteção desses bens públicos, exclusivamente condicionada a atuação de terceiros legitimados, que se mantidos inertes poderiam prejudicar a coletividade sem possibilidade de reação, o que não é desejável numa democracia.

Contudo, novamente surge a questão que norteia esta parte do trabalho no seguinte sentido: por que estabelecer a legitimidade individual apenas para demandas envolvendo direitos difusos, excluindo-se os coletivos stricto sensu e os individuais homogêneos?

Nesse ponto, percebe-se que não são razões pragmáticas, ligadas ao risco de abuso ou de má representação, que nortearam tal aparente restrição, já que abusos e má representações também podem ocorrer no âmbito das ações populares - como denunciado pela doutrina ${ }^{307}$, não se tratando também de uma suposta veia axiológica liberal e acrítica, incapaz de refletir legitimamente a unidade valorativa costurada pela Constituição.

Muito pelo contrário, razões indicam que tenha havido aí o fenômeno em que legislador diz menos do que pretendia ${ }^{308}$.

Ao que parece, a intenção do constituinte foi a de impedir que o cidadão sofra prejuízo pela lesão a um patrimônio difuso, ou seja, pertencente a um grupo de pessoas indetermináveis ligadas por uma circunstância de fato ${ }^{309}$, sem poder apresentar qualquer tipo de resistência, o que seria opressor por demais.

Nessa senda, parece natural que a mesma razão então, deve justificar a legitimidade individual para o ajuizamento de ação coletiva, ainda que não se chame de popular, visando à proteção de bem indivisível, mas coletivo stricto sensu, já que, tanto em um caso como no outro, se o individuo não possuir legitimidade para tanto, ficará refém da ação de entidades representativas, que apesar de terem de ser ativas nas suas finalidades, não podem representar obstáculo à atuação individual.

\footnotetext{
${ }^{307}$ José Carlos BARBOSA MOREIRA. “A ação popular no direito brasileiro como instrumento de tutela jurisdicional dos chamados "interesses difusos"”. Revista de Processo, 12-13. Interessante o fato de o autor trazer inúmeras soluções aos riscos da legitimidade individual para ação popular, todas elas incorporadas ao trabalho em tela para justificar a legitimidade individual para todo e qualquer tipo de demanda coletiva.

${ }^{308}$ Antonio Carlos de Araújo CINTRA; Ada Pellegrini GRINOVER; Candido Rangel DINAMARCO. Teoria Geral do Processo,p. 102. Como ensinam os autores das Arcadas: "Se considera a lei aplicável a casos que não estão abrangidos pelo seu teor literal, é extensiva a interpretação (lexplusvoluitquam dixit)".

${ }^{309}$ GRINOVER, op. cit. p. 114 , nota 305.
} 
Percebe-se, que também nos casos envolvendo direito coletivos stricto sensu, há um bem indivisível pertencente a uma coletividade, na qual indivíduos se inserem e, portanto, são codetentores do respectivo bem, podendo-se, com base nisto, transpor para esta seara os argumentos da legitimação individual para ação popular, baseados no corolário poder que o individuo deve ter, de obter tutela para um bem que, apesar de não ser exclusivamente dele, também pertence a ele.

Assim, da mesma forma que o individuo tem legitimidade para ajuizar ação popular visando à proteção do erário ou do meio ambiente, ele deve poder ingressar com ação coletiva visando à proteção de qualquer outro bem indivisível, como, por exemplo, o direito a segurança ou a informação do consumidor, nos casos envolvendo propagando enganosa ou mercantilização de produtos nocivos à saúde, ainda que figure no polo passivo apenas um ente privado, não havendo como se mensurar qual direito difuso é mais importante que o outro, a ponto de justificar uma restrição à legitimidade individual.

Em relação aos direito coletivos stricto sensu, da mesma forma, não há como se graduar sua relevância em relação aos direitos difusos, a ponto de justificar que somente no caso destes o cidadão estaria legitimado a agir, havendo exemplos, como no caso de atuação individual para melhoria do ambiente de trabalho, que ilustram com perfeição o que se quer dizer, ou seja, a posição de abertura da via jurisdicional, para que o indivíduo tenha a proteção dos seus direitos, desvinculada da atuação de determinados entes, mesmo quando o respectivo bem não pertencer exclusivamente a ele.

Dessa maneira, poderia se afirmar que, somente a restrição à legitimidade individual, para ações coletivas envolvendo direito individuais homogêneos, teria sido uma opção do constituinte e do legislador, que poderia ter preferido priorizar valores típicos de uma sociedade extremamente liberal, onde cada um deve cuidar de sua esfera jurídica, sem qualquer interferência alheia, mesmo que para beneficiar.

Entretanto, tal conclusão estaria aparentemente divorciada do texto constitucional em sua integridade, como visto, mormente quando esse diploma consagra como objetivos elementares: justiça, liberdade e solidariedade, fixando como fundamentos do Estado democrático brasileiro a cidadania, a democracia e a dignidade da pessoa humana ${ }^{310}$.

\footnotetext{
${ }^{310}$ Luis Roberto BARROSO. Fundamentos teóricos e filosóficos do novo direito constitucional brasileiro. In: Luis Roberto BARROSO (Coord.). A nova interpretação constitucional: ponderação, ...p. 37-41.
} 
Outrossim, estaria também em dissonância com relação ao direito de acesso à ordem jurídica justa, para uma apreciação mais eficiente da lesão ou ameaça a direito, pois este direito impinge o maior empenho possível na atividade de tutela dos direitos ${ }^{311}$.

Percebe-se assim, que axiologicamente a norma constitucional que prevê a legitimidade individual para a ação popular, não parece ter tido o condão de impedir a legitimidade individual para as demais ações coletivas, mas pelo contrário, teve o papel de abrir o caminho para elas, o que se afirmar visando a respostas coerentes com o sistema jurídico, compreendido na sua essência e não apenas na sua forma.

No mesmo sentido, conclui-se que tal norma constitucional não teria razões pragmáticas para criar óbice algum, pois, insista-se, o mesmo prejuízo que o abuso ou a má-representação poderia gerar no caso de ações coletivas propostas por indivíduos, também poderá haver no caso de ações populares ${ }^{312}$, expressamente aceitas pela constituição, o que ratifica toda argumentação supra sobre a ausência de tais riscos.

Não havendo razões axiológicas nem pragmáticas, conclui-se que não parece haver razoabilidade alguma em se afastar a legitimidade individual das demais ações coletivas, o que, mesmo que tivesse sido feito expressamente em algum diploma legislativo, provavelmente padeceria de vicio substancial, insista-se, pela ausência de razoabilidade, ou melhor, pela ausência de razão legítima em tal restrição, sendo certo, que qualquer restrição ao direito de liberdade e de participação das pessoas, num Estado Democrático de Direito, deve vir acompanhado de fortes razões, lastreadas em valores igualmente importantes.

\footnotetext{
${ }^{311}$ Luciano Picoli GAGNO. Direito fundamental de acesso à justiça e técnicas de otimização da atividade e do juízo probatórios, p. 37-41. Nessa oportunidade afirmamos que: "A resposta ora obtida permite a afirmação, então, de que as normas em comento, relativas ao acesso à justiça, para cumprirem o seu escopo, permitindo uma proteção concreta da autonomia e da igualdade humana, devem ser compreendidas como deveres impostos ao Estado (legislador e juiz), de e elaboração e constante aperfeiçoamento da técnica processual $[\ldots] "$.

${ }^{312}$ José Carlos BARBOSA MOREIRA. "A ação popular no direito brasileiro como instrumento de tutela jurisdicional dos chamados 'interesses difusos"'. Revista de Processo, p. 12-13. O autor ilustra como a márepresentação poderia se consumar numa ação coletiva, elencando hipóteses como: risco de colusão entre as partes, uso da ação popular com fim egoístico ou politiqueiro, e negligencia na sua condução. No mesmo sentido: Aluisio Gonçalves de Castro MENDES. "A legitimação, representatividade adequada e a certificação nos processos coletivos e as ações coletivas passivas." Revista de Processo, p. 254-255.
} 


\subsection{A legitimidade individual para hipóteses de direitos indivisíveis - ações pseudoindividuais - e sua influência sobre a legitimação do indivíduo para demandas coletivas}

Existem situações no Direito, que pela natureza indivisível da relação jurídica material que se discute no processo, a tutela jurisdicional reivindicada por um indivíduo fatalmente afetará a esfera jurídica de outras pessoas envolvidas na mesma relação material, que por suaincindibilidade, não pode sofrer qualquer intervenção externa, sem que os efeitos dessa intervenção repercutam na vida de todos aqueles que participam de tal relação ${ }^{313}$.

Tal fenômeno, quando ocorre na presença de mais de um integrante da relação material indivisível, é denominado de litisconsórcio unitário e obriga o magistrado a proferir sentença uniforme para todos os litisconsortes.

Aliás, para prestigiosa corrente doutrinaria brasileira, a imutabilidade de uma sentença judicial, proferida sobre uma relação material indivisível, afetaria também os demais participantes da relação, que não atuaram no processo, pela simples razão, de que solução diversa implicaria numa incompatibilidade prática entre julgados, que poderiam dispor de comandos normativos diferentes para uma mesma relação, gerando uma antinomia inconciliável ${ }^{314}$.

O único tempero que se poderia utilizar, para mitigar os efeitos deletérios de tal constatação em face dos princípios do contraditório e da participação, seria a coisa julgada

\footnotetext{
${ }^{313}$ José Carlos BARBOSA MOREIRA. Litisconsórcio unitário, p. 142-143. Contrariando uma visão puramente processual do fenômeno, o autor define em sua obra, a causa do litisconsórcio unitário, por meio de uma analise das "características - [...] - da situação jurídica substancial a que se há de aplicar a regra concreta formulada na sentença definitiva". Em sentido convergente: Marcelo José Magalhães BONICIO; Heitor Vitor Mendonça SICA. "Ensaio sobre aspectos materiais e processuais do litisconsórcio unitário." In: Aluisio Gonçalves de Castro MENEDES; Teresa Arruda Alvim WAMBIER. O processo em perspectiva: jornadas brasileiras de direito processual, p. 09-10. Candido Rangel DINAMARCO. Litisconsórcio, p. 8889. KazuoWATANABE. "Relação entre demanda coletiva e demandas individuais."In: Ada Pellegrini GRINOVER; Aloisio Gonçalves de Castro MENDES; Kazuo WATANABE (Coord.). Direito processual coletivo e o anteprojeto de Código Brasileiro de Processos Coletivos, p. 156.

314 Ibid., p. 138 (BARBOSA MOREIRA). Para os autores MARCELO BONICIO e HEITOR SICA, a imutabilidade só atingirá terceiros, nas hipóteses em que se tenha por objeto relação jurídica única, concebida em sua origem com a participação de um grupo determinado de pessoas, como nos casos de sociedades anônimas ou condomínios. Uma solução muito inteligente, que reduz a coisa julgada secundumeventum litis às hipóteses em que se mostra viável o emprego dessa técnica. Neste sentido: Marcelo José Magalhães BONICIO; Heitor Vitor Mendonça SICA. "Ensaio sobre aspectos materiais e processuais do litisconsórcio unitário.”In: Aluisio Gonçalves de Castro MENEDES; Teresa Arruda Alvim WAMBIER. O processo em perspectiva: jornadas brasileiras de direito processual,p. 25.
} 
secundumeventumprobationis, que evitaria aperenização de sentenças de improcedência baseadas na ausência de provas.

Para nós, entretanto, como será visto mais adiante, a coisa julgada, produzida em demanda individual envolvendo direitos indivisíveis, deverá ser secundumeventum litis, a não ser para as hipóteses em que se inviabilize o uso dessa técnica, pelo fato de haver um direito potestativo em jogo, que é objeto de litigio entre a própria classe, como no exemplo de acionistas de uma sociedade anônima, que divergem sobre a nulidade ou a validade de uma assembleia.

Tal anomalia, de extensão subjetiva da coisa julgada desfavorável, deverá ser aceita excepcionalmente, como se verá mais adiante, tendo em vista a inviabilidade de outra solução para esses casos envolvendo direitos potestativos, a não ser a conversão da demanda individual em coletiva, com os consectários legais de um procedimento coletivo, quando então se poderia aceitar a extensão subjetiva da coisa julgada sem se questionar a satisfação do devido processo legal e do contraditório ${ }^{315}$.

Pois bem, isso será objeto de uma reflexão mais profunda logo adiante, cabendo a nós no ensejo, questionarmos o seguinte: como o sistema jurídico pode aceitar que o individuo seja legitimo para demandar direitos indivisíveis, e, ao mesmo tempo, em total contradição, vedar o ajuizamento de ação coletiva pelo individuo? Não se mostra incoerente tal postura?Outrossim, não seria inócua em parte?

Se o sistema entende, que o individuo pode demandar direito indivisíveis, é porque parte da premissa, que esse poder decorre do direito de acesso à justiça, que não deve ficar obstado pelo comportamento de terceiros.

Nesse sentido, se questiona, por que o individuo pode ajuizar demanda individual versando sobre direito indivisível, mas não pode ajuizar ação coletiva para buscar a tutela do mesmo direito? Não seria em parte inócua tal vedação, já que, vedada a via coletiva sempre restará a individual?

Alguém poderia suscitar, que se o individuo ajuizasse ação coletiva sobre direito indivisível, o sistema de coisa julgada secundumeventumprobationis, pertinentea esta hipótese, permitiria que uma má argumentação da parte, sobre matéria de direito, pudesse prejudicar a coletividade, com a obtenção de uma sentença de improcedência sobre matéria

\footnotetext{
${ }^{315}$ Aluisio Gonçalves de Castro MENDES. “A legitimação, representatividade adequada e a certificação nos processos coletivos e as ações coletivas passivas.” Revista de Processo,p. 255.
} 
exclusivamente de direito, tornando-se imutável, ao contrário do que ocorreria, via de regra, no modelo de processo individual, em que se tenta prestigiar a coisa julgada secundumeventum litis.

Mas já foi visto anteriormente, que o individuo não estará sozinho nessa empreitada coletiva, pois, em se tratando de ação coletiva, um dos principais legitimados pelo sistema, o parquet, obrigatoriamente participará dessa relação, de modo a poder sanar eventual inaptidão da parte autora, sabendo-se ainda, que o comportamento do magistrado deverá ser diferenciado, externando maior preocupação com a justiça de sua decisão, e a participação de terceiros será franqueada, especialmente com a publicação de editais e intimações com este propósito.

Ademais, a possibilidade da sentença coletiva, que verse sobre direito indivisíveis, se tornar imutável apenas quando se basear nas provas, torna a utilização da tutela coletiva ainda mais atraente, pois evita o prejuízo para a coletividade, decorrente da sentença baseada na ausência de provas, e elimina o risco de incompatibilidade prática, presente quando se tem demandas individuais versando sobre direito indivisíveis, evitando-se ainda, a perenização da litigiosidade sobre a matéria, que se suporta quando apenas a sentença de procedência é capaz deimutabilizar-se.

Caso se pense igual aJOSÉ CARLOS BARBOSA MOREIRA, seguido porADA PELLEGRINI GRINOVER, no sentido de que a ação individual, sobre direito indivisível,sempre afeta a todos, a admissão da demanda individual para tais hipóteses torna a incoerência ainda mais patente, pois os efeitos de uma demanda individual seriam exatamente os mesmos de uma demanda coletiva.

Então, insista-se, por que não se autorizar a demanda coletiva pelo individuo?

Percebe-se assim, não haver uma razão consistente, que nos permita justificar a contradição ora apontada, concernente a falta de legitimidade individual para ações coletivas que versem sobre direitos indivisíveis.

Muito pelo contrário, o que existem são forte argumentos para se admitir o individuo como parte legitima em demanda versando sobre direito indivisível do qual ele seja codetentor, pois esta parece ser a vontade do legislador, quando ele legitima qualquer 
um dos eventuais credores para reivindicar sozinho em juízo o cumprimento da obrigação $^{316}$.

Por consequência, na mesma toada e pelas mesmas razões, pode-se afirmar também como anacrônica, a vedação à legitimidade individual para ações coletivas que versem sobre direitos individuais homogêneos, onde não há qualquer hipótese de prejuízo a direitos individuais, somente benefícios, que não se limitam às partes, mas alcançam o próprio Poder Judiciário, que passa a otimizar sua atuação, com a ampliação da eficácia e da imutabilidade de suas decisões, e a diminuição do número de demandas a serem julgadas.

\subsection{A instrumentalidade do processo e sua influência sobre a legitimidade individual para demandas coletivas}

A instrumentalidade do processo, segundo CANDIDO RANGEL DINAMARCO, um dos precursores dessa nova mentalidade no Brasil, impõe um novo modo de pensar, que encare o processo não mais como o resultado de teorias abstratas capazes de lhe conferir cientificidade e autonomia dentro de um universo dogmático jurídico hermético, alheio aos problemas práticos decorrentes da repercussão dos institutos processuais na sociedade $^{317}$, mas como um instrumento realizador de justiça, que tem escopos sociais, políticos e jurídico a serem alcançados, destacando-se dentre eles o de pacificação social e o de aplicação do ordenamento jurídico ${ }^{318}$.

Esse novo paradigma, que proporciona uma nova maneira de se discernirem os institutos processuais fundamentais, permite extrair dos mesmos o maior nível de aproveitamento e eficácia possível, apresentando reflexos no acesso à justiça, no modo de ser do processo, na justiça das decisões e na sua utilidade ${ }^{319}$.

\footnotetext{
${ }^{316}$ José Carlos BARBOSA MOREIRA. "Notas sobre o problema da 'efetividade' do processo". Revista da AJURIS, p. 85.

${ }^{317}$ Candido Rangel DINAMARCO. A instrumentalidade do processo,p. 386. O autor ensina que: "É preciso implantar um novo 'método de pensamento', rompendo definitivamente com as velhas posturas introspectivas do sistema e abrindo os olhos para a realidade da vida que passa fora do processo".

${ }^{318}$ Ibid., p. 214-216.

${ }^{319}$ Ibid., p. 390.
} 
No que tange ao acesso à justiça, destaca-se a identificação pela teoria instrumentalista, da necessidade de ampliação do uso do processo coletivo como instrumento de realização de justiça ${ }^{320}$, o que foi salientado por Dinamarco em meados dos anos 80 e se relaciona plenamente com a proposta ora espraiada, que vê na falta de legitimidade individual para ações coletivas um anacronismo injustificável ${ }^{321}$.

$\mathrm{Na}$ medida em que se propõe a legitimação individual para o ajuizamento de demandas coletivas, se propõe, por consectário, uma ampliação do uso do processo coletivo e, por conta disto, uma otimização da função jurisdicional pelos seus resultados, causada também por uma alteração no seu acesso, mais democrático, abrangente, eficaz e econômico.

Ao proporcionar a realização de direitos para o maior número de pessoas possível com o julgamento de uma única demanda, o processo coletivo permite um avanço, pois aumenta a efetividade da atuação estatal na atividade de pacificação social e realização dos direitos, ou seja, a jurisdição se torna mais efetiva, porque o processo se torna mais efetivo, ao realizar direitos para o maior número de pessoas possível.

Uma justiça mais capaz de proporcionar resultados concretos na vida das pessoas atende à ideia de instrumentalidade do processo em todos os seus escopos, já que, como instrumento realizador de justiça, com pacificação social e aplicação do direito, esse método será tanto melhor quanto mais abrangentes forem seus resultados, com o mínimo esforço e sem depreciação de sua qualidade.

\footnotetext{
${ }^{320}$ Ibid., p. 400-401. "O direito brasileiro não evoluiu ainda até a ampla tutela aos interesses difusos, ou aos coletivos, nem chegou a algo que se assemelhasse às classactions do sistema norte-americano; são modo de levar o exercício do poder sub espéciesjurisdictionis a elevados graus de solidarismo, com a ruptura de velhos preconceitos individualistas, como o da própria legitimação e o dos estreitos limites subjetivos da eficácia direta ou da autoridade da sentença. A recente conquista legislativa pode constituir-se, todavia, em significativo marco inicial de uma caminhada do sistema processual brasileiro por essa trilha instrumentalista, mediante técnicas capazes de dotar o processo de mais carga de utilidade social e politica".

${ }^{321}$ Ibid., p. 397. Criticando a tratamento restritivo à legitimidade processual, CANDIDO RANGEL DINAMARCO ensina que: "Tal disciplina consiste numa interpretação acanhada e insuficiente da garantia constitucional da ação e da inafastabilidade do controle jurisdicional, em contraste com as tendências solidaristas do Estado e do direito contemporâneos. Hoje, importa menos 'dar a cada um o que é seu', do que promover o bem de cada um através do bem comum da sociedade, tratando o individuo como membro desta e procurando a integração de todos no contexto social. Aquela linha de legitimação individual, válida na maioria dos casos, corresponde ao tratamento 'atômico' tradicionalmente dado aos conflitos, sem cogitar da dimensão supra-individual que estes podem muitas vezes apresentar; sucede-lhe agora o impulso doutrinário no sentido da 'molecularização' do direito e do processo, ou seja, do tratamento dos conflitos a partir de uma ótica solidarista e mediante soluções destinadas também a grupos de indivíduos e não somente a indivíduos enquanto tais".
} 
Não parecem haver razões para a restrição do processo e dos seus resultados, ainda mais se vista tal questão pelo ângulo da instrumentalidade. Se o processo é instrumento, do qual se deve extrair o máximo de resultados, ele deve ser o melhor instrumento, e se o seu objetivo é proporcionar paz e justiça, que isto ocorra na maior medida do possível, para o maior número de pessoas e não para grupos restritos.

Para tanto, a ampliação da legitimação individual para o processo coletivo se mostra um importante mecanismo, ao proporcionar a extensão dos efeitos positivos de um processo a todos que sejam codetentores do mesmo bem ou estejam em situação homogênea, sem que eles precisem despender os esforços que um processo individual exige.

Percebe-se então, a plena consentaneidade entre a proposta em foco e o paradigma da instrumentalidade do processo, uma instrumentalidade voltada para a repercussão social dos resultados do processo $^{322}$, com o foco no ser humano e nos direitos fundamentais insculpidos no arcabouço ético de nossa constituição ${ }^{323}$, que não ignora o caráter cientifico do conhecimento, mas também não se conforma com as barreiras impostas pelo comodismo da ausência de reflexão pragmática e axiológica.

\subsection{A teoria da instrumentalidade das formas e sua influência sobre a legitimidade individual para demandas coletivas}

A teoria da instrumentalidade das formas se baseia na máxima "não há nulidade sem prejuízo", do francês "pas de nulitésansgrief",324, ou seja, não há necessidade de declaração de nulidade de um ou mais atos processuais, com a sua eventual repetição,

\footnotetext{
322 Ibid., p. 221.

${ }^{323}$ Luciano Picoli GAGNO. Direito fundamental de acesso à justiça e técnicas de otimização da atividade e do juízo probatórios, p. 98. Dissemos nessa oportunidade, que: "Assim sendo, não há como se recusar, hodiernamente, com o aparecimento de convenções mundiais e continentais sobre direitos humanos, que estabelecem globalmente as diretrizes a serem observadas pelos Estados em busca de efetividade e proteção da liberdade, a existência de uma técnica recheada com preceitos éticos, que coloca a dignidade humana no foco das atenções e, assim, alia-se a novos objetivos a serem alcançados, diferentes do simples cumprimento das regras postas (objetivos como o de proteção das liberdades e de participação social nas decisões estatais ilustram bem essa atual perspectiva valorativa)."

${ }^{324}$ José Roberto dos Santos BEDAQUE. Efetividade do processo e técnica processual,p. 425-426.
} 
quando a prática defeituosa ou a omissão em relação à forma não houver acarretado prejuízo ao direito das partes, que se visa a proteção com a estrita observância da forma.

Essa teoria parte da premissa de que a forma tem por escopo a satisfação de dois valores, quais sejam: celeridade e segurança, que além de informarem o procedimento, precisam ser harmonizados, a fim de que um não se sobreponha desproporcionalmente ao outro $^{325}$.

Sendo assim, todas as normas processuais tem o condão de garantir um instrumento seguro e eficaz, capaz de produzir uma decisão justa e realizadora de efeitos concretos no mundo fenomenológico, de modo que, toda vez que a segurança e a eficácia não restarem prejudicadas pela inobservância da forma, o defeito não precisará ser reconhecido, prosseguindo-se com o processo normalmente.

Obviamente haverá algumas situações em que esse raciocínio não poderá ser aplicado, pois o prejudicado pela inobservância da forma é a própria atividade jurisdicional, como no caso de impedimento ou de incompetência absoluta ${ }^{326}$.

Ademais, a aplicação dessa teoria pressupõe uma análise retrospectiva do processo, ou seja, ao seu final, já que, se identificada no primeiro instante da sua prática, como consequência de uma visão prospectiva do processo, a nulidade merecerá sempre ser sanada, a fim de que se economizem atos potencialmente desnecessários, que nem sempre poderão ser aproveitados com base na instrumentalidade das formas ${ }^{327}$.

Os exemplos clássicos de utilização de uma visão retrospectiva no processo, para tentar aproveitá-lo ao máximo, são: o processo em que houve citação nula, mas a sentença foi de improcedência do pedido ${ }^{328}$, ou o caso em que o menor não fora representado por

\footnotetext{
${ }^{325}$ Ibid., p. 49. Segundo JOSÉ ROBERTO DOS SANTOS BEDAQUE: "Processo efetivo é aquele que, observado o equilíbrio entre os valores segurança e celeridade, proporciona às partes o resultado desejado pelo direito material. Pretende-se aprimorar o instrumento estatal destinado a fornecer tutela jurisdicional. Mas constitui perigosa ilusão pensar que simplesmente conferir-lhe celeridade é suficiente para alcançar a tão almejada efetividade. Não se nega a necessidade de reduzir a demora, mas não se pode fazê-lo em detrimento do mínimo de segurança, valor também essencial ao processo justo".

${ }^{326}$ Ibid., p. 193-194.

${ }^{327}$ Ibid., p. 172-173.

${ }^{328}$ Ibid., p. 463-464.
} 
um capaz, ou não teve a intervenção do parquet, mas a sentença lhe foi integralmente favorável $^{329}$.

Nesses casos, percebe-se claramente que, apesar de inobservada forma garantidora de segurança, em um caso ao réu (citação), no outro caso ao menor, o processo deverá ser aproveitado, inclusive a sentença, tendo em vista a ausência de prejuízo para as partes protegidas pela forma desrespeitada, ao se sagrarem vencedoras da demanda; a forma tinha justamente este objetivo, proporcionar chance de vitória.

Por esse rumo, o mesmo raciocínio pode ser aqui implantado para justificarmos a legitimidade individual para ações coletivas, mormente para aqueles que não compartilham integralmente da leitura dos valores constitucionais ora realizada, afastando os supostos óbices pragmáticos de tal proposta, relativos aos riscos da má-representação individual.

Isso porque, se a coisa julgada produzida em processo coletivo nunca poderá prejudicar o individuo, face ao seu caráter secundumeventum litis, e a coletividade nunca será prejudicada pela leniência do autor, tendo-se em vista a coisa julgada secundumprobationem e a participação obrigatória do M.P. - ente expressamente legitimado, não aparenta haver porque se defender a exclusão do individuo do rol de legitimados para demandas coletivas.

Nesse ponto, pode-se adaptar a máxima da instrumentalidade, pois se não houver chance de prejuízo para a coletividade, não há que se atribuir nulidade a demanda coletiva conduzida por individuo.

A restrição da legitimidade mostra-se como uma formalidade inútil, desnecessária, ante aos demasiados mecanismos de proteção da coletividade contra a má-representação (participação do M.P., poderes instrutórios oficiais e coisa julgada diferenciada), ou até mesmo nociva, na medida em que reduz as possibilidades do seu manejo.

Percebe-se então, que mesmo que não houvesse fundamento jurídico constitucional para se defender uma abertura axiológica pertinente à legitimidade individual para demandas coletivas, ainda assim esta poderá ser admissível, com base na instrumentalidade das formas, que preconiza a ausência de nulidade se não houver prejuízo pela inobservância estrita da forma.

\footnotetext{
${ }^{329}$ Ibid., p. 446. Falando também sobre o aproveitamento da sentença proferida sem a intervenção do parquet, nos casos em que a lei a exige: Humberto THEODORO JÚNIOR. "As nulidades no Código de Processo Civil."Revista de Processo, p. 52.
} 
Alguém poderia objetar a impossibilidade de se aplicar tal proposta, pelo fato do juiz ter o dever de ofício de reconhecer a nulidade no primeiro momento em que identificala, de modo que, havendo ilegitimidade, esta teria que ser reconhecida de plano, numa visão prospectiva do processo, a não ser que uma circunstância tão explícita como essa só fosse percebida no final, comportando o julgamento em prol da economia, pela total ausência de chance de prejuízo decorrente da coisa julgada.

Entretanto, contra tal pensamento, devem ser registrados os seguintes argumentos.

Primeiro, o de que a legitimidade individual para ações coletivas, ainda que considerada uma inobservância da forma estrita, seria uma informalidade incapaz de prejudicar valores como a segurança ou a celeridade, como visto.

Muito pelo contrário, vimos que a os poderes instrutórios do juiz, a participação obrigatória do parquet e a sistemática da coisa julgada no processo coletivo brasileiro não dão chances a qualquer crise de segurança.

No que tange a celeridade, a legitimação individual para demandas coletivas tem justamente o condão de conferir maior capacidade ao processo, de concretização dos seus efeitos no mundo dos fatos, na medida em que a sentença tem sua eficácia estendida apenas para favorecer as pessoas que não foram partes, o que permite a redução do número e da complexidade de demandas individuais.

Percebe-se então, a particularidade que há nessa hipótese de suposta inobservância da forma, diferenciando-a da maioria, para as quais a teoria da instrumentalidade fora concebida.

A hipótese ora concebida, de um processo coletivo conduzido por parte individual, assim como a de inobservância de outras formas residuais, que não possuem mais razão de ser, comportaria plenamente um juízo de instrumentalidade das formas, ou seja, de aproveitamento do ato praticado sem a observância da devida forma, mesmo numa dimensão prospectiva do processo, ou seja, ainda no seu inicio, o que decorre justamente da ausência de fundamento para a forma restritiva da legitimidade ${ }^{330}$, e da existência de

\footnotetext{
${ }^{330}$ Ibid., p. 425 (BEDAQUE). Sintetizando o pensamento instrumentalista, JOSÉ ROBERTO DOS SANTOS BEDAQUE conclui que: "Esta é a base do raciocínio instrumentalista, segundo o qual pressupõe-se seja a disciplina legal do ato processual a mais adequada e idônea ao fim pretendido. E a observância dela é exigida apenas na medida em que se revele realmente necessária a que o escopo seja alcançado. A ideia fundamental é, pois, a relação de adequação entre a forma e o fim".
} 
fundamento para a sua ampliação, com base na celeridade e na busca por efetividade sem perda de segurança.

É o mesmo que acontece com a exigência de que a reconvenção e a exceção de incompetência venham em peças autônomas em relação à contestação ${ }^{331}$.

Se inobservada essa regra, ainda que no início do processo, ou seja, no primeiro instante após o oferecimento da reconvenção ou da exceção, o juiz poderá ignorar o vicio de forma e admitir a resposta na integra, com base na ausência de prejuízo tangente a inobservância estrita do procedimento.

Tudo isto, simplesmente porque não existe fundamento racional para que se exija que a reconvenção e a exceção de incompetência venham em peças autônomas.

Não bastasse isso, releva-se ainda o fato de que, se o ajuizamento de uma ação coletiva por um indivíduo fosse uma nulidade, ela seria sanada com a integração do Ministério Publico como fiscal da lei, já que nesta condição a referida instituição poderá exercitar as mesmas faculdades da parte autora numa demanda coletiva, como visto no tópico atinente a tal tem.

Conclui-se, então, que pela incapacidade de causar prejuízo a quem não foi parte, bem como pela obrigatória participação de entidade expressamente legitimada pela lei, pode-se admitir a legitimidade individual para demandas coletivas, ainda que se considere tal proposta despida de fundamento constitucional, com base numa aplicação particularizada da teoria da instrumentalidade das formas, baseada na capacidade dessa técnica supostamente subversiva proporcionar maior grau de efetividade ao processo, ao contrário do que normalmente ocorre quando há a prática de um ato ao arrepio da lei.

\subsection{Legitimidade extraordinária do indivíduo: democracia ou abuso?}

Como visto até aqui, defende-se a ampliação da legitimidade para o processo coletivo como medida confluente com os valores constitucionais e com os resultados práticos que se esperam do processo.

\footnotetext{
${ }^{331}$ Ibid., p. 416. O autor noticia que a jurisprudência vem relativizando esse tipo de erro. No STJ pode ser conferido o seguinte precedente: REsp 549587/PE, Recurso Especial 2003/0099712-8, Rel. Min. Felix Fischer, $5^{\text {a }}$ Turma do Superior Tribunal de Justiça, DJe de 10/05/2004.
} 
Dentre os valores constitucionais, o que concerne ao modelo democrático de Estado, expressamente designado na Constituição Federal como sendo inspirador do Estado brasileiro $^{332}$, merece destaque nesta oportunidade, para que se debata se realmente a legitimação do individuo para demandas coletivas reforça a democracia ou se, diferentemente, representaria um abuso.

Para tanto, mostra-se importante fazermos um breve esclarecimento do que se entende por democracia, para ao final construirmos o que pode ser entendido atualmente por democracia e aí, concluirmos se a legitimidade individual para demandas coletivas é democrática ou abusiva.

Por democracia entende-se a forma de governo do povo, pelo povo e para o povo $^{333}$, por meio da qual todos os cidadãos podem participar $^{334}$, o que tem como símbolo mais emblemático o sufrágio universal, pelo qual os indivíduos escolhem seus representantes políticos, que ocuparão vagas no legislativo e no executivo representando a população.

Democracia, portanto, é o sistema de governo que permite a todos participarem das decisões do Estado, direta, indireta ou semidiretamente ${ }^{335}$.

Nesse sentido, questiona-se, como o individuo participa da decisão relacionada ao ajuizamento ou não de uma ação coletiva?

Se a democracia pressupõe participação do individuo no governo de um Estado, e se o Estado tem por função a proteção dos direito, não seria mais democrático permitir que os indivíduos também participem dessa atividade de maneira mais ampla e livre, mormente quando tal participação não encontra óbices materiais que dificultem ou encareçam-na, muito pelo contrário, pois geram economia para a Jurisdição e, consequentemente, para o Estado?

\footnotetext{
${ }^{332}$ Miguel REALE. O estado democrático de direito e o conflito das ideologias,p. 1-2.

${ }^{333}$ Hans KELSEN. A democracia.p. 140.Norberto BOBBIO. Estado, governo, sociedade: para uma teoria geral da politica, p. 135. Dalmo de Abreu DALLARI. Elementos de teoria geral do estado,p. 145. Paulo BONAVIDES. Ciência Política, p. 266. Luis Fernando BARZOTTO. A democracia na constituição, p. 1317. LUIZ FERNANDO BARZOTTO faz uma interessante explanação, atribuindo a Abraham Lincoln a conhecida fórmula: "governo do povo, pelo povo e para o povo", e traduzindo a concepção democrática de autores como Rousseau, Kelsen e Aristóteles, como plebiscitária, procedimental e deliberativa respectivamente.

${ }^{334}$ BOBBIO, op. cit. p. 137, nota 333 .

${ }^{335}$ José AFONSO DA SILVA. "O sistema representativo, democracia semidireta e democracia participativa."Revista do Advogado, p. 96.
} 
Nesse contexto, registra-se que a legitimação individual para ações coletivas pode proporcionar uma participação mais efetiva, ou seja, mais capaz de produzir resultados, pois permite ao cidadão também decidir sobre o ajuizamento ou não de uma ação coletiva, sobre a demanda pela proteção ou não de um direito coletivo.

Não parece ter sentido, no atual estágio de evolução democrática, excluirmos o cidadão dessa decisão, principalmente quando ele é o principal afetado por ela, ou seja, ele tem que pode demandar direitos coletivos, já que é um codetentor dos mesmos, possuindo por vezes um direito individual, que pode ser protegido simultaneamente para todos que se encontram na mesma situação.

O cidadão tem que poder decidir pelo ajuizamento de uma ação coletiva, sempre que houver um direito difuso ou coletivo em jogo, ou sempre que houver um direito individual que possa ser tratado coletivamente.

Essa é uma decisão que não pode ficar na esfera exclusiva de entidades públicas ou privadas, porque a democracia pressupõe a participação de todos os atores possivelmente afetados com um determinado ato ${ }^{336}$.

A democracia indireta é uma solução encontrada dentro do novo cenário social, econômico e politico existente ${ }^{337}$, para que todos possam participar sem que a atividade legislativa, principal corolário da democracia ${ }^{338}$, se torne caótica, mas sempre que a participação direta for possível, ou ao menos a semidireta, com um sistema de participação diferenciado, elas deverão ser prestigiadas, por proporcionarem maior nível de participação.

Apesar de ser impensável que todos os indivíduos possam participar diretamente de uma demanda coletiva, tendo em vista a ausência de meio materiais para tanto, o que justificaria uma atuação por meio de representantes, é certo também que esses representantes não podem excluir a possibilidade de atuação do individuo, sob pena de se criar desproporcional restrição ao direito fundamental de acesso à justiça, de petição aos Poderes Públicos para a proteção dos direito, ao devido processo legal, e, por fim, ao próprio modelo democrático de Estado.

\footnotetext{
${ }^{336}$ KELSEN, op. cit. p. 142, nota 333.

${ }^{337}$ BONAVIDES, op. cit. p. 273, nota 333. Para o autor, no contexto mundial de hoje mostra-se impossível supor a realização de uma democracia direta.

${ }^{338}$ Jean Jacques ROUSSEAU. Do contrato social: princípios de direito político, p. 58-59.
} 
Na hipótese em que um indivíduo tem um direito violado, mas não pode agir para obter sua tutela em vista da sua indivisibilidade, ou apenas pode agir para si, mesmo em se tratando de uma hipótese homogênea, obviamente haverá um déficit de participação, já que o ideal é que o individuo amplie suas formas de influenciar nos atos do Estado, inclusive no ato de proteção dos direitos.

Outro aspecto que deve ser relevado no ensejo, que auxilia significativamente na argumentação ora espraiada, de associação da legitimidade individual para ações coletivas à democracia, é o fato da legalidade, que impõe a todos, igualmente, a observância das normas jurídicas, ser um consectário da democracia ${ }^{339}$.

Nesse cenário, pode-se concluir que, na medida em que eu tenho violação a direitos coletivos ou individuais homogêneos olvidadas pelo Estado, pelo fato de nenhum ente expressamente legitimado ter agido, eu tenho um prejuízo indireto à legalidade consubstanciado no desrespeito em massa às leis e, por via de consequência, à democracia, homologado pelo próprio Estado.

Se o Estado tem o dever de proteger os direitos individuais, difusos, coletivos e individuais tratados coletivamente, e se o individuo tem o direito democrático de participar dos atos e decisões do Estado, por consectário ele deve poder ajuizar demandas para a proteção de direitos individuais, difusos, coletivos e individuais tratados coletivamente, ao menos quando o direito em jogo diga respeito a ele.

Insista-se, que participação nas decisões do Estado ou nos processos de decisão do Estado, não significa apenas poder votar, sendo certo que a democracia abrange além da ideia de participação, a ideia de legalidade, como resultado dos valores fundamentais a qualquer Estado Democrático, quais sejam: liberdade e igualdade ${ }^{340}$.

Quando o Estado, por meio dos seus entes legitimados, ingressa ou deixa de ingressar com uma ação coletiva, foi tomada uma decisão sem que os cidadãos tenham sido ouvidos diretamente, de modo que o cidadão não pode se manter prejudicado, submetido a uma situação de violação de direito, sem poder reagir e sem poder reivindicar igual proteção para todos que se encontrem em situação similar.

Obviamente, seria impossível a realização de um plebiscito com tal objeto, de modo que a única forma de se afastar o déficit democrático decorrente de tais limitações, é pela

\footnotetext{
${ }^{339}$ Norberto BOBBIO. O futuro da democracia: uma defesa das regras do jogo, p. 65-66.

${ }^{340}$ KELSEN, op. cit. p. 205, nota 333.
} 
legitimação individual para ações coletivas, para que o individuo possa também decidir, quando ele quiser ingressar com uma demanda coletiva para a proteção de determinado direito.

Novamente, não parece haver razão que justifique a exclusão do individuo dessa decisão, como vem sendo discutido durante todo este tópico, muito pelo contrário, as razões preponderam flagrantemente para o reconhecimento da legitimidade individual para ações coletivas.

Ainda que o indivíduo não possa participar diretamente das decisões, que são tomadas para o ajuizamento ou não de ações coletivas, pela inviabilidade prática que isto encontraria, que ele ao menos possa tomar decisões, caso possua uma insatisfação com a violação de um direito coletivo ou tratado coletivamente.

Dessa maneira ele participará democraticamente das decisões que podem lhe afetar, não dizendo se concorda ou não com as propostas dos outros, mas decidindo pelo fazer, o que caracteriza também uma forma de participação.

Insista-se, participar das decisões não deve significar apenas poder votar, principalmente no atual contexto, em que as relações tecidas na sociedade são altamente complexas e massificadas.

Diante das novas realidades que são apresentadas constantemente, temos de apresentar respostas diferenciadas, sendo certo que, diante da possibilidade de haver demandas coletivas, tem que haver a possibilidade do individuo também demandar coletivamente.

Somente podendo decidir pelo agir o cidadão participará da questão envolvendo a necessidade ou não de se demandar coletivamente sobre determinado direito, sendo certo que ele participa diretamente e com maior proximidade das atividades estatais quando assim decide.

Do contrário, como um individuo insatisfeito com a leniência dos entes expressamente legitimados pela lei, poderia proceder para proteger um direito difuso, coletivo ou individual homogêneo que esteja sendo violado?

Poder decidir não pode ser resumir a poder votar, devendo significar também, poder demandar via processo coletivo, a proteção de direitos difusos, coletivos ou individuais 
homogêneos, mormente quando estes vêm sendo ignorados pelas entidades que deveriam se preocupar com eles, em afronta a legalidade democrática.

Deve-se registrar ainda, que a legitimidade individual para demandas coletivas está inserida, também, dentro da esfera de liberdade individual, que toda pessoa deve ter em um Estado Democrático, por não parecer ter razoabilidade nem racionalidade, a ideia de que um indivíduo deva amargar com a violação perene do direito do qual ele é codetentor, ou de que a sua atuação não possa beneficiar pessoas que se encontram em situação de análoga violação de direitos.

O homem livre tem que ser livre para defender seus direitos e, também, para atuar em defesa da sociedade se assim decidir; qualquer restrição neste sentido terá que ser herculeamente fundamentada.

No contexto em que estamos inseridos, o acesso à justiça é elementar não apenas para a proteção individual, mas constitui direito fundamental de se reivindicar a tutela de direitos coletivos ou a tutela coletiva de direitos individuais homogêneos ${ }^{341}$, pois como ser ético, que deve além de não fazer o mal ao próximo, fazer o bem sempre que possível ${ }^{342}$, o homem tem sua esfera de dignidade reduzida quando impedido de alcançar o fim que sua natureza lhe deu.

Retirar do cidadão essa faculdade é consolidar um Estado autoritário, que desconfia da capacidade e idoneidade dos seus indivíduos vistos isoladamente.

Conclui-se então, que a democracia parece se fortalecer com a possibilidade do individuo decidir pela propositura de uma ação coletiva, seja pela ampliação da participação individual no Estado, seja pela ampliação dos mecanismos de proteção à legalidade, o que pressupõe a legitimação individual para tanto, permitindo-se asserir, com isto, que a legitimação individual para demandas coletivas pode ser um pressuposto da democracia moderna, que convive com relações massificadas e violações de direitos em massa, devendo proporcionar ao indivíduo a chance de optar pela busca de uma justiça de

\footnotetext{
${ }^{341}$ Elton VENTURI. Processo civil coletivo: a tutela jurisdicional dos interesses difusos, coletivo e individuais ..., p. 102.

${ }^{342}$ Fábio Konder COMPARATO. A afirmação histórica dos direitos humanos, p. 23. Referindo-se às lições de Kant, FABIO KONDER COMPARATO afirma que: "Ademais, disse o filósofo, se o fim natural de todos os homens é a realização de sua própria felicidade, não basta agir de modo a não prejudicar ninguém. Isto seria uma máxima meramente negativa. Tratar a humanidade como um fim em si implica o dever de favorecer, tanto quanto possível, o fim de outrem. Pois, sendo o sujeito um fim em si mesmo, é preciso que os fins de outrem sejam por mim considerados também como meus".
} 
massa, não ficando refém das decisões tomadas pelos entes legitimados previstos na lei e nem de irreversíveis situações de violação coletiva de direitos.

Se a democracia é um direito fundamental, a ser satisfeito na maior medida do possível como os demais direitos fundamentais ${ }^{343}$, nada mais natural que se legitime o indivíduo para demandas coletivas, a partir do momento em que se conclui que isto proporciona um ganho para a democracia de um Estado, já que aumenta o nível de participação do individuo nas atividades estatais, especialmente a sua participação na realização da função jurisdicional.

\subsection{As vantagens obtidas com a legitimidade individual para demandas coletivas}

Dentre os aspectos técnicos fundamentais que necessariamente se ligam à análise da legitimidade individual para demandas coletivas, destaca-se o concernente a existência de vantagens práticas decorrentes desse instituto.

Sabendo-se que a jurisdição possui o fim de resolver conflitos com a proteção dos direitos $^{344}$ e que o processo é o instrumento que proporciona o alcance desse objetivo, por meio da instauração de uma relação jurídica animada por um procedimento em contraditório $^{345}$, tem-se por natural, que a legitimação individual para demandas coletivas, como técnica processual que é, será vantajosa na medida em que proporcione um melhor desempenho dessa atividade de resolução de conflitos com a proteção de direitos.

O processo, por ser um instrumento, tem que possuir institutos condizentes com os resultados esperados, de maneira que, se estes resultados são a resolução de crises com a proteção de direitos, ele deve proporcionar a melhor resposta possível e o seu manuseio deve extrair o máximo de resultado, conforme preconiza a postura instrumentalista do processo $^{346}$.

\footnotetext{
${ }^{343}$ Robert ALEXY. Teoria dos direitos fundamentais, p. 90.

${ }^{344}$ Antonio Carlos de Araújo CINTRA; Ada Pellegrini GRINOVER; Candido Rangel DINAMARCO. Teoria Geral do Processo, p. 129.

${ }^{345}$ Candido Rangel DINAMARCO. Fundamentos do processo civil moderno, p. 103.

${ }^{346}$ Candido Rangel DINAMARCO. A instrumentalidade do processo, p. 386.
} 
Buscando a utilização de critérios que possam orientar essa análise sobre possíveis benefícios derivados da legitimidade individual para demandas coletivas, pode-se afirmar que a atividade de resolução de conflitos pode ser considerada melhor sob dois critérios diferentes, quais sejam: o quantitativo, relacionado ao tempo necessário para o julgamento das causas e ao número de causas que é resolvido, e o qualitativo, relacionado à justiça das decisões proferidas e do procedimento observado.

Essa asserção decorre da premissa já estabelecida em importantes trabalhos, de que o processo efetivo orbita em torno de dois valores fundamentais, quais sejam: segurança e celeridade $^{347}$, sendo o alcance de um processo maximamente célere e seguro a quimera maior de todo processualista.

Como dito por GIUSEPPE CHIOVENDA, "o processo deve proporcionar a quem tem um direito tudo aquilo e precisamente aquilo que ele tem o direito de obter" ${ }^{\text {"34 }}$, de modo que, quanto mais céleres forem os resultados do processo, mais próximos eles estarão do que a parte receberia, caso o direito lhes fosse satisfeito espontaneamente; no mesmo rumo, quanto mais seguros forem os resultados do processo, também.

O grande dilema é que em muitos casos a obtenção de maior celeridade representa uma perda de segurança e vice-versa ${ }^{349}$.

Sem embargo, toda vez que identificada uma técnica que proporcione maior celeridade sem que haja uma perda de segurança, ou o inverso, mais segurança sem perda de celeridade, essa deve ser aproveitada, concluindo-se assim, que um instituto ou técnica processual é vantajoso, na medida em que acrescente celeridade ou segurança ao processo, sem que a satisfação de um valor represente renuncia ao outro, já que, nessa medida, o instituto ou técnica processual contribuirá para o alcance da finalidade jurisdicional, para a qual o processo é feito.

\footnotetext{
${ }^{347}$ José Roberto dos Santos BEDAQUE. Efetividade do processo e técnica processual,p. 49 e 54. Na página 49 de sua obra, o autor ensina que: "Processo efetivo é aquele que, observado o equilíbrio entre os valores segurança e celeridade, proporciona às partes o resultado desejado pelo direito material [...]. Não se nega a necessidade de reduzir a demora, mas não se pode fazê-lo em detrimento do mínimo de segurança, valor também essencial ao processo justo". No mesmo sentido: José Rogério Cruz e TUCCI. "Garantia da prestação jurisdicional sem dilações indevidas como corolário do devido processo legal." Revista de Processo, p. 73.

${ }^{348}$ Giuseppe CHIOVENDA. Dell'azione nascente dal contrato preliminare. In: Saggidi dir. proc. civ.p. 110 , apud DINAMARCO, op. cit. p. 385, nota 346.

${ }^{349}$ BEDAQUE, op. cit. p. 48, nota 347. TUCCI, op. cit. p. 73, nota 347.
} 
No caso em tela, a legitimidade individual para demandas coletivas parece apresentar as seguintes vantagens:

a) propicia ao indivíduo pleno acesso à justiça, com a possibilidade dele obter a tutela de bens indivisíveis (difusos ou coletivos stricto sensu) ${ }^{350}$, o que, até então, ou vem sendo feito de maneira inconsciente e atécnica, por meio de ações pseudoindividuais, ou vem sendo negado em flagrante violação ao direito fundamental de acesso à justiça do individuo. Essa ampliação do acesso à justiça se traduz num ganho de justiça procedimental, qualidade e segurança ao processo, que passa a assegurar o acesso à proteção judicial a um maior número de pessoas;

b) propicia uma maior participação do individuo lesado no processo, o que contribui para a elaboração da causa de pedir e a demonstração dos fatos ${ }^{351}$, se traduzindo num ganho de qualidade e segurança, já que, muitas vezes tais fatores são prejudicados pelo distanciamento entre o ente coletivo legitimado e os fatos;

c) propicia um aumento no número de demandas coletivas levadas ao exame do Judiciário, o que se traduz em mais celeridade para que a sociedade e o indivíduo obtenham a tutela do direito lesado, já que o processo coletivo pode eliminar ou simplificar bastante os processos individuais $^{352}$ e, muitas vezes, proporciona a tutela de direitos que jamais seriam objetos de ações exclusivamente individuais, seja pela desinformação das pessoas, seja pelo baixo valor econômico do direito lesado se considerado individualmente ${ }^{353}$, o que se traduz em mais segurança para a sociedade.

Os entes expressamente legitimados, por diversas razões, dentre elas a timidez de suas ações e o distanciamento dos fatos, não dão vazão a quantidade de conflitos coletivos ou coletivizáveis existentes na sociedade, o que se constata por uma rápida reflexão sobre as inúmeras situações da vida moderna, que proporcionam relações massificadas das mais variadas, envolvendo milhares e às vezes milhões de pessoas, que sofrem com cláusulas ou

\footnotetext{
${ }^{350}$ Aluísio Gonçalves de Castro MENDES; Larissa Clare Pochmann da SILVA. "A legitimidade ativa do individuo nas ações coletivas." Revista de Processo, p. 43. No mesmo sentido: Aluisio Gonçalves de Castro MENDES. "A legitimação, representatividade adequada e a certificação nos processos coletivos e as ações coletivas passivas.” Revista de Processo,p. 254.

${ }^{351}$ Bruno Silveira de OLIVEIRA. "Flexibilização do binômio 'processo tradicional' / 'processo coletivo'. Breve análise da presença do individuo em processos coletivos". Revista da Procuradoria Geral do Estado do Espirito Santo, p. 71.

${ }^{352}$ Aluisio Gonçalves de Castro MENDES. “A legitimação, representatividade adequada e a certificação nos processos coletivos e as ações coletivas passivas.” Revista de Processo,p. 255.

${ }^{353}$ Aluísio Gonçalves de Castro MENDES; Larissa Clare Pochmann da SILVA. "A legitimidade ativa do individuo nas ações coletivas." Revista de Processo,p. 44.
} 
práticas injustas nas relações de consumo, com a degradação do meio ambiente causada por grandes indústrias, pela vulnerabilidade do trabalhador e grupos minoritários, e com o abuso ou a omissão do Estado.

Com o aumento no número de demandas coletivas, pressupõe-se a obtenção de diversos benefícios, tais como:

a) a redução do número de demandas individuais, ou pelo menos a sua simplificação, já que a coisa julgada positiva beneficiará a todos os indivíduos, e ainda a coisa julgada negativa afetará as demandas pseudoindividuais, conforme se verá mais abaixo;

b) a potencialização da tutela jurisdicional, com a ampliação de sua abrangência, de modo a incidir sobre mais bens e para um maior número de pessoas, que muitas vezes desconhecem seus direitos ou não possuem interesse econômico na sua obtenção isolada;

c) e maior atenção ao princípio da isonomia e à segurança jurídica, já que a eficácia erga omnes da sentença se encarregará de dar tratamento igualitário a todos os membros da coletividade representada.

Percebe-se assim, que a legitimação do individuo para figurar como autor de demanda coletiva poderá ser benéfica, na medida em que efetivamente proporcione os resultados acima prospectados, sem trazer os prejuízos elencados por muitos dos que se opõem a essa legitimação, que ao temerem abusos e a má-representação, ignoram as inúmeras respostas que o próprio sistema já oferece (controle judicial da litigância de máfé, participação obrigatório do M.P., poderes instrutórios do juiz, coisa julgada secundumeventum litis e probationis), conforme visto no corpo desta pesquisa.

Alguns dos principais benefícios trazidos pela legitimação do individuo ora discutida, se fundam, então, nas seguintes premissas:

a) é benéfica uma ampliação do uso da tutela coletiva e;

b) ocorre uma ampliação do uso da tutela coletiva na medida em que se autoriza o seu manejo pelo individuo ${ }^{354}$.

Se o uso ampliado da tutela coletiva é benéfico, por tudo que se disse até agora, especialmente no que tange ao contexto social e econômico moderno, e aos novos

\footnotetext{
${ }^{354}$ Aluísio Gonçalves de Castro MENDES; Larissa Clare Pochmann da SILVA. "A legitimidade ativa do individuo nas ações coletivas." Revista de Processo, p. 44. No mesmo sentido: Aluisio Gonçalves de Castro MENDES. "A legitimação, representatividade adequada e a certificação nos processos coletivos e as ações coletivas passivas.” Revista de Processo, p. 255.
} 
contornos das relações jurídicas concebidas nesse novo cenário mundial; e se a legitimação do individuo será capaz de proporcionar um maior número de demandas coletivas ajuizadas, já que os entes coletivos mostram-se incapazes de absorver toda litigiosidade contida na sociedade, o que se constata pela reflexão sobre inúmeras situações, que poderiam ser objeto de demandas coletivas e não o são, talvez pela distância que muitas vezes tais entes possuem em relação aos fatos veiculados nas demandas coletivas; pode-se concluir, então, que a legitimação do individuo será positiva para o sistema jurisdicional brasileiro.

A partir dessa mudança, pensa-se que a jurisdição poderá oferecer respostas mais rápidas e isonômicas, resolvendo conflitos e protegendo direitos para um maior número de pessoas e sobre uma maior variedade de bens, o que vai ao encontro dos fins jurisdicionais, de resolução de conflitos com a proteção de direitos, para os quais o processo deve sempre estar voltado.

Quando a jurisdição passa a resolver conflitos envolvendo bens que até então não eram objetos de proteção, para um maior número pessoas - que muitas vezes nem seriam protegidas, de maneira mais rápida e isonômica, ela ganha em celeridade e segurança, ou seja, nos seus valores centrais, já que, além da maior velocidade, assegura uma proteção jurisdicional mais ampla e igualitária.

Dessa forma, conclui-se que a legitimação do individuo para demandas coletivas é uma técnica processual aparentemente condizente com os fins jurisdicionais, de recomendável adoção nas sociedades atuais e futuras, por ser capaz de proporcionar as vantagens espraiadas no presente item, sem contrastar com valores igualmente importantes.

\subsection{A restrição criada pelo rol de legitimados da Lei de ACP e do CDC}

Mediante uma rápida leitura das leis relativas à Ação Civil Pública e ao Código de Defesa do Consumidor, percebe-se que em ambas, o rol de legitimados para o manejo das respectivas ações coletivas exclui o indivíduo.

A partir dessa constatação, inserida em toda argumentação axiológica e técnica até então despendida, é de se discutir se tal restrição pode ser considerada adequada, ou se a 
sua inconstitucionalidade material ${ }^{355}$ pode ser arguida, na medida em que os valores constitucionalmente positivados parecem preconizar rumos diversos daquele que exclui o individuo do rol de legitimados para o processo coletivo.

A realização desse debate passa necessariamente por uma análise dos resultados prospectados com a ampliação da legitimidade ora proposta - conforme o tópico passado, em cotejo com os resultados aparentemente desejados pelas normas da constituição, mormente as concernentes aos princípios que regem o Estado Democrático brasileiro, de liberdade, justiça, solidariedade e dignidade humana, e aos direitos fundamentais de acesso à justiça, ação penal subsidiaria da pública, ação popular e devido processo legal ${ }^{356}$, este último, tanto sob uma ótica formal como substancial ${ }^{357}$.

Foi visto no tópico antecedente, que a legitimação individual para demandas coletivas pode proporcionar ao individuo, pleno acesso à justiça para obtenção de tutela relativa a direitos indivisíveis, além de proporcionar maior proximidade do autor da ação com os fatos, o que facilita não só a condução argumentativa da causa como a própria iniciativa em se propor uma demanda coletiva, ampliando a sua utilização de modo a abranger uma litigiosidade contida ${ }^{358}$, traduzida em pessoas que jamais obteriam proteção jurisdicional sobre o respectivo direito, seja por desinformação, seja pela baixa expressão econômica de uma demanda individual isolada ${ }^{359}$.

\footnotetext{
${ }^{355}$ Luiz Guilherme MARINONI; Daniel Francisco MITIDIERO; Ingo Wolfgang SARLET. Curso de direito constitucional, p. 783. Segundo os autores: "A inconstitucionalidade material se relaciona com o que acaba de ser dito, uma vez que tem a ver com o conteúdo da lei, ou melhor, com a não conformação do ato do legislador, em sua substância, com as regras e princípios constitucionais. Há inconstitucionalidade material quando a lei não está em consonância com a disciplina, valores e propósitos da Constituição."

${ }^{356}$ Norma constitucional da qual também se extrai o valor efetividade, conforme lição de: José Rogério Cruz e TUCCI. "Garantia da prestação jurisdicional sem dilações ..."In: ; Rogerio Lauria TUCCI. Devido processo legal e tutela jurisdicional,p. 106. Segundo o autor: "O processo, como é curial, presta-se à concreção do direito a jurisdição, sendo que seu desenrolar, com estrita observância dos regramentos ínsitos ao denominado dueprocessoflaw, importa a possibilidade de inarredável tutela do direito subjetivo material objeto de reconhecimento, satisfação ou assecuração, em Juízo.

${ }^{357}$ Sobre o devido processo legal substantivo: BRASIL. Supremo Tribunal Federal. ADI 173/DF, Relator: Min. Joaquim Barbosa, julgamento: 25/09/2008, órgão julgador: Tribunal Pleno, requerente: Confederação Nacional da Indústria - CNI, requerido: Congresso Nacional, publicação: DJ 20-03-2009. Disponível em: <http://www.stf.jus.br/portal/jurisprudencia〉. Acesso em: 30 de out. 2009.

${ }^{358}$ Quem trabalha com a ideia de litigiosidade contida, marcadamente caracterizada pelas pequenas causas, pela desinformação e pela massificação dos conflitos, é o professor Watanabe, que introduz ao tema em: Kazuo WATANABE. "Acesso à justiça e sociedade moderna." In: Candido Rangel DINAMARCOet al.Participação e processo,p. 132.

${ }^{359}$ José Carlos BARBOSA MOREIRA, “A efetividade do processo de conhecimento.” Revista de Processo, p. 136. No mesmosentido: Janet Cooper ALEXANDER. "An introduction to Class Actions Procedure in the United States”.Disponível em:http://law.duke.edu/grouplit/papers/classactionalexander.pdf, p. 1.
} 
Verificou-se, que além de benefícios diretos, ligados à qualidade do acesso à justiça, mais pleno e aproximado da realidade cotidiana, a legitimação individual para demandas coletivas pode proporcionar também benefícios indiretos, ligados diretamente à ampliação do uso da tutela coletiva.

Utilizado o processo coletivo em maior escala, mais direitos, de mais pessoas, podem ser protegidos com menor gasto de tempo e recursos, esta foi uma das premissas estabelecidas no tópico anterior.

Percebe-se então, que quando falamos em ampliação do acesso à justiça pela autorização de que o individuo demande coletivamente sobre bem indivisível, e na qualificação desse acesso pela proximidade que o individuo possui com os fatos e o interesse em discussão, estamos ligando diretamente alguns efeitos da legitimação individual ora estudada, com o direito fundamental de acesso à justiça e ao devido processo legal, além dos valores de justiça, liberdade e dignidade humana.

Isso porque, não podemos pensar na satisfação de tais valores, sem que o indivíduo tenha meios de proteger os bens dos quais ele seja codetentor (direitos indivisíveis), o que fica nítido quando analisamos os institutos da ação popular e das ações pseudoindividuais, as quais o próprio sistema aparenta reconhecer como necessárias e imanentes à ideia de acesso à justiça.

Sem essa autonomia individual, além do acesso à justiça, ficaria prejudicado também o devido processo legal, além dos valores liberdade e justiça, já que as pessoas privadas dos bens que detém, ainda que se tratem de bens indivisíveis, não gozam de autonomia para dispor dos mesmos e, portanto, sofrem restrição à sua esfera de liberdade injustamente ${ }^{360}$.

Sobre o devido processo legal, este não se reduz a uma norma que impõe a observância de regras procedimentais ou direitos de defesa, mas abrange o direito a um processo équo e giusto ${ }^{361}$, capaz propiciar a tutela prometida pelo direito material e pelo

\footnotetext{
${ }^{360}$ Luciano Picoli GAGNO. Direito fundamental de acesso à justiça e técnicas de otimização da atividade e do juízo probatórios, p. 31-32.

${ }^{361}$ Luigi Paolo COMOGLIO. Etica e técnica del "giusto processo", p. 48-49 e 58-59.
} 
Estado Democrático de Direito, pois a efetividade não é algo avesso ao devido processo, muito pelo contrário, é um pressuposto deste ${ }^{362}$.

Não bastasse, a ideia substancial de devido processo legal, que irradia para o uso da proporcionalidade, recomenda que, para se atender ao valor preponderante em uma determinada hipótese, não se sacrifique completamente o valor conflitante, excesso que parece se consumar quando simplesmente se nega a legitimação individual para a ação coletiva, fora das hipóteses da ação popular, sob o pretexto dos riscos de abuso ou de prejuízo para a coletividade.

Como visto acima, o próprio sistema legal já é pródigo em mecanismos que reduzem significativamente tais riscos, de modo que não se justifica a restrição do rol de legitimados, por ser mostrar excessiva e desnecessária.

Outrossim, quando falamos que a legitimação do individuo proporcionará o aumento no uso de demandas coletivas, com os consectários positivos daí advindos, também conseguimos relacionar estes com as normas constitucionais e sua finalidade.

Desse modo, podemos falar que, com a celeridade auferida em virtude dos processos coletivos, obtém-se a satisfação de direitos fundamentais como: acesso à justiça, devido processo legal e razoável duração do processo.

Ademais, valores como justiça e solidariedade são também atendidos pelo aumento do uso do processo coletivo, pois este distribui justiça a mais pessoas, sobre bens que até então não se pensava tutelar - às vezes pelo seu baixo valor econômico ou pela falta de informação, em total sintonia também com os direitos fundamentais de acesso à justiça e devido processo legal.

Os direitos fundamentais, como mandamentos de otimização, impõem que os fins sejam alcançados na maior medida possível ${ }^{363}$, de modo que, havendo alternativas com relação à definição dos legitimados para o manejo da ação coletiva, deverá ser escolhida aquela que proporcione o maior acesso à justiça possível, sem o sacrifício desnecessário de valores que podem se mostrar colidentes em certa situação ${ }^{364}$, como o contraditório por exemplo.

\footnotetext{
${ }^{362}$ José Rogério Cruz e TUCCI. "Garantia da prestação jurisdicional sem dilações ..."In: Lauria TUCCI. Devido processo legal e tutela jurisdicional,p. 106-107.

${ }^{363}$ Robert ALEXY. Teoria dos direitos fundamentais,p. 90.

${ }^{364}$ Ibid., p. 119. ; Rogerio
} 
Sempre que a satisfação máxima de um direito fundamental se mostrar complexa pela existência de valores igualmente fundamentais, mas colidentes, caberá à realização de uma proporcionalidade em sentido estrito ${ }^{365}$, aferir dentre as medidas adequadas à consecução daquele fim, qual se mostra mais necessária e quais se mostram desnecessárias $^{366}$.

No caso em tela, contudo, a legitimação do individuo para demandas coletivas, como visto, não traz prejuízos ao contraditório ou ao acesso à justiça, por conta de toda a técnica que envolve o processo coletivo brasileiro, relativa especialmente à participação obrigatória do M.P., aos poderes instrutórios do juiz e a coisa julgada secundumeventum litis e probationis, que tornam a tutela coletiva pretendida pelo individuo igualmente segura em relação à tutela coletiva pretendida por qualquer outro ente.

Percebe-se então, que a conclusão pela inconstitucionalidade da restrição em questão - de legitimidade individual para o ajuizamento de ações coletivas, em virtude do rol previsto na LACP e no CDC, apesar de difícil de ser sustentada, demanda um exercício de proporcionalidade, aliado à compreensão das normas constitucionais e à aferição de conformidade entre os efeitos obtidos com o atual rol de legitimados e o sistema constitucional pátrio, confrontando-se em seguida, os resultados deste raciocínio, com a hipótese inversa, por meio da qual se análise a congruência dos efeitos da legitimação individual para demandas coletivas em relação às mesmas normas constitucionais em comento.

Feito isto, poderemos ver maior conformidade na compreensão do rol expresso na LACP e no CDC com a Constituição, se suas previsões puderem ser consideradas simplesmente exemplificativas de legitimados à ação coletiva e que, portanto, não excluam a legitimidade individual, por todas as razões que vem sendo expostas até então, o que, entretanto, não nos dá segurança suficiente para falar e inconstitucionalidade de normas.

Juridicamente falando, tem-se toda possibilidade de se interpretar as regras de legitimidade da LACP e do CDC em conformidade com a Constituição Federal, como

\footnotetext{
${ }^{365}$ Ibid., p. 116-117 e 119-120.

${ }^{366}$ Virgílio AFONSO DA SILVA. Direitos Fundamentais: conteúdo essencial, restrições e eficácia, p. 171. $\mathrm{O}$ autor explica bem o exame da necessidade envolvido na ponderação de princípios, ensinando que: "Não há, nesse sentido, relação alguma entre necessidade ou exigibilidade e imposição da conduta. Em segundo lugar porque o exame da necessidade de uma medida, nos termos da regra da proporcionalidade, é um teste comparativo. Isso significa que um ato estatal é necessário, quando comparado a outras alternativas que poderiam ter sido utilizadas para a mesma finalidade".
} 
dispõe a Lei da ADIn, que trata tanto da técnica de interpretação conforme como da declaração parcial de nulidade sem redução de texto ${ }^{367}$, ambas aplicáveis também às hipóteses de controle difuso ${ }^{368}$, ou seja, o controle de constitucionalidade ora sugerido independente do seu manejo pela via concentrada e abstrata.

Por fim, não podemos olvidar o acréscimo de isonomia que a ampliação do uso do processo coletivo traz, pela eficácia erga omnes que atinge suas decisões, sendo este justamente o cerne dos seus benefícios.

Sem dúvida alguma, não é desejável que as pessoas se dividam entre aquelas que tiveram o direito reconhecido em juízo e as que tiveram o mesmo direito negado, já que essa divergência de posicionamento, sendo oriunda de um mesmo Estado, traz insegurança às relações sociais, justamente o que não se deseja quando se instaura um processo.

No mais, ressalta-se apenas que, como dito anteriormente, os valores liberdade e participação também são afetados quando eu excluo o individuo do rol de legitimados para a ação coletiva, pois eu tiro da sua esfera individual uma faculdade, qual seja: a de representar a coletividade numa demanda dessa espécie.

Sem a faculdade de poder decidir pelo ajuizamento de uma ação coletiva ou não, resta ao individuo apenas participar do litigio como litisconsorte, o que não lhe confere o mesmo grau de participação na sociedade e nas decisões do Estado, que lhe seria conferido com o direito de instaurar uma demanda coletiva.

Conclui-se assim, que a interpretação da LACP e do CDC, no que concerne ao rol de legitimados à ação coletiva, deve ser realizada de modo a se concluir por serem exemplificativas tais previsões, sem que delas se possa excluir a legitimidade individual para ações coletivas, técnica de interpretação conforme que permite o controle de constitucionalidade das leis e o aprimoramento do ordenamento, sem a necessária declaração de inconstitucionalidade da norma.

\footnotetext{
${ }^{367}$ Luiz Guilherme MARINONI; Daniel Francisco MITIDIERO; Ingo Wolfgang SARLET. Curso de direito constitucional,p. 823.

${ }^{368}$ Ibid., p. 823.
} 
PARTE III - ANÁLISE PROSPECTIVA DOS RESULTADOS IDEALIZADOS COM A COLETIVIZAÇÃO SOBRE DIREITOS INDIVISIVEIS OU INDIVIDUAIS HOMOGÊNEOS

12A COLETIVIZAÇÃO DE DEMANDAS VERSANDO SOBRE DIREITOS INDIVISIVEIS 


\subsection{Os casos de ações pseudoindividuais: a ausência de taxatividade e a decisão que converte uma ação pseudoindividual em coletiva}

Em diversos momentos, o legislador brasileiro dispôs expressamente sobre a legitimidade individual para hipóteses envolvendo direitos indivisíveis, sem, no entanto, exigir que todos envolvidos fizessem parte da relação processual $^{369}$, o que aparenta a sua preocupação com o direito fundamental de acesso à justiça, numa perspectiva individualizada.

Para que o individuo não sofra prejuízos em relação a direitos que ele compartilhe com terceiros, em caso de violação desses direitos, qualquer codetentor poderá reivindicar a tutela jurisdicional, sem ficar condicionado ao comportamento de qualquer outro e sem ser obrigado a incluir, no polo passivo, todas as pessoas que fazem parte da relação material, já que isto inviabilizaria o andamento do processo.

Como consequência desse prestígio ao direito fundamental de acesso a justiça, a coisa julgada obtida numa demanda individual, que verse sobre direitos indivisíveis, poderá ensejar problemas, com hipóteses de conflitos práticos entre sentenças que, regulando a mesma relação, disponham de comandos normativos antagônicos ${ }^{370}$, o que será objeto de maior atenção no tópico seguinte, onde exploraremos as alternativas para tal problemática.

Essas demandas, que versam sobre direitos indivisíveis, denominadas pela doutrina de ações pseudoindividuais ${ }^{371}$, já que propagam efeitos sobre uma relação jurídica material multipolarizada, podem ser ilustradas, com a admissão que o legislador positivou, por exemplo, para que o sócio de sociedade anônima questione a validade de assembleia, ou

\footnotetext{
${ }^{369}$ José Carlos BARBOSA MOREIRA. Litisconsórcio unitário,p. 131. Marcelo José Magalhães BONICIO;Heitor Vitor Mendonça SICA. "Ensaio sobre os aspectos materiais e processuais do litisconsórcio unitário." In: Aluisio Gonçalves de Castro MENEDES; Teresa Arruda Alvim WAMBIER. O processo em perspectiva: jornadas brasileiras de direito processual, p. 280. Humberto THEODORO JÚNIOR. Curso de Direito Processual Civil: teoria geral do direito processual civil e processo de conhecimento, p. 116. FredieDIDIER JÚNIOR. Curso de Direito Processual Civil: teoria geral do processo e processo de conhecimento, p. 323.

${ }^{370}$ Ibid., p. 143-144 (BARBOSA MOREIRA). BONICIO; SICA, op. cit. p. 300, nota 369.

${ }^{371}$ Kazuo WATANABE. "Relação entre demanda coletiva e demandas individuais."In: Ada Pelegrini GRINOVER; Aluisio Gonçalves de Castro MENDES; Kazuo WATANABE (Coord.). Direito Processual Coletivo e o anteprojeto de Código Brasileiro de Processos Coletivos, p. 156. BONICIO; SICA, op. cit. p. 285 , nota 369.
} 
reivindique a tutela do patrimônio social, em desfavor do diretor responsável por um eventual dano ${ }^{372}$.

Não obstante, na doutrina e na jurisprudência, em diversos momentos se trabalha com outros exemplos, tais como: ação visando à inclusão de determinado medicamento na lista de medicamentos fornecidos pelo SUS, ou ação visando à reparação de danos causados pela poluição ambiental, na qual se requer a paralisação da atividade danosa ${ }^{373}$.

Apesar de setor respeitado da doutrina, entender pela inadmissibilidade de demandas pseudoindividuais, que deveriam ser manejadas apenas na forma coletiva ${ }^{374}$, pensamos que uma intepretação sistemática do ordenamento conduz à conclusão contrária, de que o direito fundamental de acesso à justiça do individuo não pode ser submetido à natureza indivisível do direito, existindo a intenção na legislação pátria, de se prestigiar esse direito fundamental, quando se permite que o indivíduo busque a tutela jurisdicional, para bens que não pertencem exclusivamente a ele.

Destarte, por que o sistema admitiria uma ação individual visando à declaração de nulidade de uma assembleia de sociedade anônima, e não admitiria uma ação em que se pede o desligamento de uma chaminé industrial, ou a instalação de um filtro capaz de reduzir a poluição ambiental?

Tanto em um caso como noutro, tem-se um direito transindividual, que não pode ter sua tutela obstada somente por este aspecto, ou seja, somente porque pertence a uma coletividade, especialmente quando as entidades coletivas, que deveriam se preocupar com tal situação, se mantém inertes, permitindo que os indivíduos, codetentores desse direito, sejam prejudicados.

Entende-se, portanto, que a demanda pseudoindividual sempre será possível, nos casos envolvendo direitos transindividuais, como um consectário do direito fundamental de acesso à justiça no atual Estado Democrático de Direito ${ }^{375}$, não havendo taxatividade nas hipóteses que o legislador expressamente previu.

\footnotetext{
372 BARBOSA MOREIRA, op. cit. p. 130, nota 369.

${ }^{373}$ BONICIO; SICA, op. cit. p. 280 e 295, nota 369.

${ }^{374}$ WATANABE, op. cit. p. 160, nota 371.

${ }^{375}$ Aluísio Gonçalves de Castro MENDES; Larissa Clare Pochmann da SILVA. "A legitimidade ativa do individuo nas ações coletivas." Revista de Processo,p. 43. No mesmo sentido: Aluisio Gonçalves de Castro MENDES. "A legitimação, representatividade adequada e a certificação nos processos coletivos e as ações coletivas passivas.” Revista de Processo,p. 254.
} 
Contudo, parece ideal que essas demandas sejam processadas pelo modelo do processo coletivo $^{376}$, especialmente criado para hipóteses que tenham por objeto, direitos indivisíveis ou individuais homogêneos, pela particularidade existente neste seguimento do direito material, para que a tutela jurisdicional seja prestada com maior adequação e, com isto, proporcione resultados mais céleres e seguros ${ }^{377}$.

Mais adiante se falará nos benefícios que advirão dessa conversão, cabendo por ora, considerar como a o juiz deverá fazer essa conversão.

Verificando o juiz, que o caso em concreto envolve direitos indivisíveis, deverá ele, primeiramente, analisar se não se trata de hipótese de litisconsórcio necessário, ou seja, se não será obrigatória a participação de todos os envolvidos no litigio.

Não havendo necessariedade, pela impossibilidade prática de se conduzir uma demanda que envolva um número excessivo de partes $^{378}$, mostrar-se-á muito mais conveniente, que essa demanda tramite por meio de um processo coletivo, no juízo determinado como competente pela LACP e o CDC, com a participação obrigatória do M.P. e a incidência do regime de coisa julgada secundumeventumprobationis.

Entretanto, o magistrado deverá considerar, previamente, se o autor da ação ao menos se afirma codetentor do direito indivisível discutido ${ }^{379}$, já que do contrário faltaria total legitimidade processual ativa, até para a demanda pseudoindividual.

Sendo hipótese de direito indivisível, havendo pluralidade excessiva de indivíduos ligados ao mesmo direito, de modo a tornar inviável a presença de todos no mesmo

\footnotetext{
${ }^{376}$ Aluisio Gonçalves de Castro MENDES. "A legitimação, representatividade adequada e a certificação nos processos coletivos e as ações coletivas passivas." Revista de Processo, p. 255.

${ }^{377}$ José Roberto dos Santos BEDAQUE. Direito e processo: influencia do direito material sobre o processo, p. 46-47. O autor demonstra a preocupação que o modelo coletivo traz com a questão da representação, afirmando que: "O processo de massa pressupõe o direito coletivo. A efetivação deste vai depender de provimento jurisdicional apto a solucionar conflitos envolvendo interesses de grupo. É a tutela jurisdicional coletiva, que traz consigo inúmeros problemas a serem resolvidos, dentre eles um de natureza politica: eficácia e autoridade da sentença atingindo pessoas que não participaram do contraditório."

${ }^{378}$ Cassio Scarpinella BUENO. As classactions norte-americanas e as ações coletivas brasileiras: pontos para uma reflexão conjunta. Revista de Processo, p. 93. Falando sobre as classactions, o autor ensina que: "Seu cabimento restringe-se àquelas hipóteses em que a união de todos que poderiam ser partes em um mesmo processo (que se afirmam titulares da lide levada ao Estado-juiz, portanto) não é plausível (até porque seu numero poderia chegar a milhões) ou porque sua reunião, em um só processo, daria ensejo a dificuldades insuperáveis quanto à jurisdição e à competência."
}

${ }^{379}$ Jack H. FRIEDENTHAL; Mary Kay KANE; Arthur R. MILLER.Civil procedure,p. 727.Sobreessaquestão, a doutrinaamericanaentendeque: "If they have a personal stake in the outcome of the litigation, the representatives are likely to undertake a full prosecution or defense.", o quesignifica, queosrepresentantesatuam com maisempenho, se tiverem um interesseenvolvido no litígio. 
processo, e havendo legitimidade processual ativa para uma demanda pseudoindividual, tendo em vista, o fato de o autor participar da relação jurídica indivisível, então será possível a conversão da ação individual em coletiva, após previa realização de um contraditório sobre o assunto, com o ingresso do M.P., que poderá aditar a inicial e praticar todos os demais atos necessários ao exercício de sua função institucional, como visto em tópico anterior.

Lembra-se apenas, que a constatação sobre a indivisibilidade do direito passará pela análise da relação jurídica material, que só poderá ser considerada incindível, sea intervenção praticada sobre ela se imutabilizar sobre todos os demais participantes ${ }^{380}$.

Sendo o direito indivisível, caberá ainda ao juiz, diagnosticar qual espécie, se difuso ou coletivo stricto sensu, pois se difuso, deverá ser exposta qual circunstância fática passou a ligar a coletividade à parte contraria, e se coletivo strito sensu, qual relação jurídica prévia havia entre os membros da coletividade, ou entre estes e a parte contrária.

Aliás, a menção aos elementos acima especificados, propiciará maior qualidade à fundamentação e maior controle sobre a decisão, já que obrigará o magistrado a expor todo o percurso do seu raciocínio sobre a indivisibilidade do direito, tornando a decisão mais transparente e fácil de ser discutida ${ }^{381}$.

\subsection{A sistemática da coisa julgada em relação às ações pseudoindividuais}

A coisa julgada, como um atributo da decisão judicial que se torna imutável, deve se restringir às partes que participaram do processo no qual a respectiva decisão fora produzida, o que se designa de limite subjetivo da coisa julgada ${ }^{382}$.

\footnotetext{
${ }^{380}$ José Carlos BARBOSA MOREIRA. Litisconsórcio unitário,p. 146.

${ }^{381}$ T. SAUVEL. Histoire du jugement motive, p. 5-6, apud Chaïm PERELMAN.Lógica juridical, p. 213.

${ }^{382}$ Marcelo José Magalhães BONICIO; Heitor Vitor Mendonça SICA. "Ensaio sobre os aspectos materiais e processuais do litisconsórcio unitário." In: Aluisio Gonçalves de Castro MENEDES; Teresa Arruda Alvim WAMBIER. O processo em perspectiva: jornadas brasileiras de direito processual,p. 298.
} 
Tal delimitação tem sua razão nos direitosfundamentais ao devido processo legal eao contraditório ${ }^{383}$, que tem como consectários, outros princípios constitucionais como:ampla defesa, publicidade efundamentação, e que, ao estabelecer a possibilidade de defesa efetiva, como um requisito constitucional para a legitimidade das decisões judiciais, impede que terceiros estranhos à relação processual sejam atingidos pela imutabilidade inerente à coisa julgada ${ }^{384}$.

Dessa maneira, apenas as partes são impedidas de submeter novamente ao crivo do Judiciário, causas que já tenham sido tratadas em demandas anteriores, seja pela proibição de ações idênticas, seja pela eficácia preclusiva da coisa julgada.

Problema grave surge, quando o objeto de julgamento em uma demanda traduz uma intervenção em relação jurídica incindível, de modo que a prestação da tutela afetará igualmente, de maneira uniforme, a todos que participem de tal relação.

A eficácia da sentença sobre terceiros é algo reconhecido como existente e admitido como válido, entretanto, toda vez que essa eficácia interferir de alguma forma na esfera jurídica de um terceiro, por respeito ao contraditório, esse necessariamente deve ter a oportunidade de discutir essa situação em juízo, podendo, com isto, obter a tutela da sua esfera jurídica.

Assim, por exemplo, ocorre nas hipóteses de embargos de terceiro, ou de maneira antecipada na demanda de oposição, sempre envolvendo bens ou direitos relacionados a litígios multipolarizados.

Não obstante, nas hipóteses de direitos indivisíveis, decorrentes de relações jurídicas incindíveis, a possibilidade de revisão dos efeitos da decisão judicial transitada em julgado que atinja terceiros, poderá implicar em conflitos práticos entre decisões judiciais igualmente importantes ${ }^{385}$, resultando na fulminação da ideia de coisa julgada, pela sua total vulneração.

Em se tratando de uma tutela de intervenção em relação incindível, toda vez que isto ocorresse a pedido de um interessado envolvido na relação, se poderia ter um comando

\footnotetext{
${ }^{383}$ BUENO, op. cit. p. 100-101, nota 378. O autor traça um paralelo entre a representatividade adequada e a extensão subjetiva da coisa julgada, ensinando que, no processo coletivo, apenas se admite maior amplitude subjetiva de tal instituto, por se considerar que o contraditório não fica prejudicado quando o representante da coletividade for tido como adequado pelo Judiciário.

${ }^{384}$ Sobre a questão relativa à inexistência, ineficácia ou nulidade da decisão proferida sem a participação do réu: José Roberto dos Santos BEDAQUE. Efetividade do processo e técnica processual,p. 463-480.

${ }^{385}$ BARBOSA MOREIRA, op. cit. p. 144, nota 380.
} 
diferente do anterior, que pela unitariedade do objeto, afetaria a todos, abrindo margem para novas insatisfações, traduzidas em novas demandas e potenciais novas mudanças, num indo e vindo infinito e indesejado para a estabilidade das relações humanas.

Exemplo clássico pode-se extrair, da hipótese de demanda que visa à anulação de questão de concurso público ${ }^{386}$. Anulada a questão, ocorrerá alteração na ordem de classificação, o que, fatalmente, desagradará às pessoas que não se beneficiaram da anulação, por terem acertado a questão, por exemplo.

Imaginem se outros candidatos entrassem com uma ação para que fosse declarada válida a questão. Se tramitassem simultaneamente, os processos poderiam ser reunidos e julgados ao mesmo tempo, mas, em se tratando de demandas ajuizadas em momentos distantes, poderia se ter uma decisão judicial que anulasse a questão e alterasse a ordem e classificação, e outra que não, mantendo-a, perguntando-se aí: qual prevaleceria?

Problema semelhante, a doutrina identificou em casos envolvendo assembleias e patrimônio de sociedades anônimas e condomínios ${ }^{387}$, ou ainda em ações visando à interrupção da poluição no meio ambiente ou a sua recuperação ${ }^{388}$.

Nos casos ambientais, por exemplo, podemos imaginar duas sentenças: uma primeira, julgando improcedente o pedido de desligamento de uma chaminé, por se entender que os materiais, despejados na atmosfera por ela, não oferecem risco suficiente à saúde humana e ao ecossistema; e uma segunda, determinando o desligamento da mesma chaminé, por se entender que ela despeja na atmosfera, poluentes altamente nocivos a vida humana e ao ecossistema da região.

Os julgados acima, tanto num como noutro, apresentam grave conflito prático e não meramente lógico, de modo a impedir que ambas as decisões sejam satisfeitas simultaneamente, pois a preservação de uma prejudicará a outra.

Percebe-se que no primeiro caso, se tem demandas diametralmente opostas, ajuizadas por pessoas diferentes, mas que integram a mesma relação jurídica unitária,onde se visa à interferência, seja para lhe alterar, seja para lhe ratificar.

\footnotetext{
${ }^{386}$ BONICIO E SICA, op. cit. p. 280, nota 382.

${ }^{387}$ BABROSA MOREIRA, op. cit. p. 130, nota 380. BONICIO; SICA, op. cit. p. 297, nota 382.

${ }^{388}$ BONICIO; SICA, op. cit. p. 289 e 294, nota 382.
} 
No segundo caso, se tem demandas parecidas, ajuizadas por pessoas diferentes e com fatos que podem conter algumas nuances, mas visando ambas à tutela de um direito indivisível, qual seja: o meio ambiente.

Nesses casos, como a aplicação das regras comuns de coisa julgada acabaria por fulminar a coisa julgada, a doutrina propôs a regra da coisa julgada secundumeventum litis, que funciona bem ou mal na segunda hipótese, onde demandas ambientais similares obtém julgados diferentes, mas não quando se tem demandas diametralmente opostas sobre um único objeto $^{389}$, revelando interesses antagônicos, mas legítimos, entre os membros da relação unitária.

Pela coisa julgada secundumeventum litis, a imutabilidade só é adquirida quando a demanda é julgada procedente, todavia, na primeira hipótese, como se tem demandas diversas, com pedidos diametralmente antagônicos sobre uma única relação jurídica, a aplicação da coisa julgada secundumeventum litis não resolveria nada.

Aparentemente, sempre que possívela obtenção de duas sentenças de procedência, que disponham sobre o mesmo objeto de maneira antagônica, tendo sido requeridas por partes diferentes, que pertencem a uma única relação material, mas possuam interesses contrários, então não será viável a aplicação da coisa julgada secundumeventum litis.

Nesses casos, a existência de membros da mesma relação material, mas com interesses completamente opostos, impedirá que se use a técnica de se imutabilizar apenas a sentença de procedência, pois com ela, um grupo de pessoas seria beneficiado injustamente em detrimento do outro, de modo que, a coisa julgada, qualquer que seja, ou deverá valerá para todos, ou não valerá para ninguém, acabando-se com ela neste último caso.

Parece que fora pensando nessas hipóteses, que JOSÉ CARLOS BARBOSA MOREIRAafirmou que a coisa julgada envolvendo relações incindíveis afetaria a todos os

\footnotetext{
${ }^{389}$ Sobre o assunto: Enrico Tulio LIEBMAN. Eficácia e autoridade da sentença e outros escritos sobre a coisa julgada,p. 93-100. Candido Rangel DINAMARCO. Processo Empresarial, p. 494-505.

Litisconsórcio, p. 217-218. José Rogério Cruz e TUCCI. Limites subjetivos da eficácia da sentença e da coisa julgada, p. 256. Eduardo TALAMINI. "Partes, terceiros e coisa julgada (os limites subjetivos da coisa julgada)". In:Fredie DIDIER JÚNIOR; Teresa Arruda Alvim WAMBIER (Coord.). Aspectos polêmicos e atuais sobre os terceiros no processo civil e assuntos afins, p 196-246. Para esses autores, terceiros estranhos ao processo não podem ser atingidos pela coisa julgada, ainda que se trate de direito indivisível, o que fatalmente trará problemas, se pensarmos no exemplo de demandas diametralmente opostas sobre o mesmo objeto, propostas por autores diferentes.
} 
envolvidos na relação ${ }^{390}$, o que diante dos exemplos acima, parece mesmo impossível de se contestar, a não ser, insista-se, que admitamos o fim da coisa julgada para essas hipóteses, o que também não parece ideal.

Tentando superar essa dicotomia, a jurisprudência reconheceu a necessariedade do litisconsórcio nessas hipóteses, para que todos envolvidos na relação incindível participem também do processo ${ }^{391}$, o que na prática, transforma a situação num litisconsórcio multitudinário, impedindo o desenvolvimento do processo.

É especialmente para hipóteses de relação indivisível, que gerariam litisconsórcios multitudinários, que surge o processo coletivo (como as classactions), visando à conciliação entre a coisa julgada e o contraditório ${ }^{392}$.

Com isso, nem a coisa julgada fica prejudicada nessas hipóteses, para que se prestigie o contraditório, nem o inverso, pois a representação permite uma satisfação, ainda que por meio de uma ficção, do contraditório efetivo.

Fixa-se no ensejo, a conclusão ora erigida, de que a solução oferecida pela técnica de coisa julgada secundumeventum litis, não resolve todos os problemas envolvendo coisa julgada e os direitos indivisíveis, mas apenas parte deles, já que tal técnica se deparará com interesses legítimos sobre a mesma relação, mas diametralmente opostos,pretendidos por pessoas diferentes, mas que participam da mesma relação material unitária, sem poder definir qual polo se beneficiará com taldinâmica, ou seja, qual procedência que prevalecerá, se a anulação ou se a declaração de validade.

\footnotetext{
${ }^{390}$ José Carlos BARBOSA MOREIRA. Litisconsórcio unitário,p. 144. Os autores MARCELO BONICIO e HEITOR SICA encontram uma solução interessantíssima para esse problema, que mescla elementos das duas correntes existentes, trabalhando com a plena extensão subjetiva da coisa julgada apenas nos casos que envolvam relações jurídicas constituídas em sua origem por um grupo determinado de pessoas, como nos casos de uma sociedade anônima ou um condomínio. Marcelo José Magalhães BONICIO; Heitor Vitor Mendonça SICA. "Ensaio sobre os aspectos materiais e processuais do litisconsórcio unitário." In: Aluisio Gonçalves de Castro MENEDES; Teresa Arruda Alvim WAMBIER. O processo em perspectiva: jornadas brasileiras de direito processual,p. 302.

391 BRASIL.AgRg no REsp 1436274 / PI,Agravo Regimental no Recurso Especial 2014/0006756-6, Min. Humberto Martins, Órgão Julgador: Segunda Turma, data do julgamento: 01-04-2014, data da publicação: DJe 07/04/2014, disponível em: www.stj.jus.br. Nesse julgado, o STJ afasta a necessidade de litisconsórcio necessário nos casos envolvendo concurso público, mas deixa registrada toda a divergência jurisprudencial que já houve anteriormente sobre o assunto.

${ }^{392}$ Humberto Dalla Bernardina de PINHO. A natureza jurídica do direito individual homogêneo e sua tutela pelo Ministério Público como forma de acesso à justiça,p. 132-133. O autor traz uma informação histórica importante, ao ensinar que: "[...], no século XVII foi editado o chamado Bill of Peace, que autorizava o processamento de uma ação sob a forma coletiva. Isto se dava em torno da ideia do common interest ou commonality, em que a coisa julgada abrangia os direitos de todos os membros da classe de maneira uniforme, uma vez que o numero de pessoas envolvidas era muito grande e inviabilizava a formação de um litisconsórcio".
} 
Nesse contexto, adere-se, então, ao posicionamento do autor Barbosa Moreira, inspirado na doutrina alemã e parte da italiana ${ }^{393}$, seguido posteriormente por Grinover ${ }^{394}$, ao menos para essas hipóteses às quais não se presta outra solução.

Nesses casos, a coisa julgada terá de afetar a terceiros, se se quiser que ela continue a existir para tais hipóteses, sem criar desigualdades injustificáveis.

Nesse ponto, passamos a desenvolver então, os benefícios que a conversão de uma demanda individual em coletiva proporcionará em tais situações.

\subsection{As vantagens decorrentes da coletivização de demanda individual que verse sobre direitos indivisíveis: a coisa julgada secundumeventumprobationise a extensão objetiva da coisa julgada (aproveitamentein utilibus)}

Pela explanação acima, percebe-se que a coletivização de demandas individuais, que versem sobre direitos indivisíveis, proporcionará benefícios claros com relação aos limites subjetivos da coisa julgada, já que permitirá, com plena adequação e respaldo jurídico, que uma única decisão seja imutável para todos codetentores do direito objeto da demanda, seja ela de procedência ou de improcedência, desde que não se funde na insuficiência das provas, o que se conhece como coisa julgada secundumeventumprobationis.

Dessa maneira, nas ações individuais que versem sobre direitos indivisíveis, mas comportem autilização da coisa julgada secundumeventum litis, por inexistir interesse antagônico legítimo de outras pessoas que não façam parte do processo,como no exemplo da ação ambiental onde se requer o desligamento de uma chaminé, com a sua conversão para uma demanda coletiva, a coisa julgada que será produzida impossibilitará a todos codetentores do direito à proteção ambiental, de reivindicar novos julgamentos sobre a matéria, salvo se a sentença se fundar na insuficiência de provas ou se ocorrerem fatos novos.

\footnotetext{
${ }^{393}$ BARBOSA MOREIRA, op. cit. p. 26 e 62-65, nota 390.

${ }^{394}$ Ada Pellegrini GRINOVER. Coisa julgada erga omnes, secundumeventum litis e secundumprobationem. Revista de Processo,p. 13.
} 
Tal efeito reduziria a litigiosidade sobre a questão e, consequentemente, o número de demandas judiciais envolvendo o mesmo objeto, sem prejudicar os direitos individuais relacionados.

Tal resultado não seria alcançado no modelo individual de processo, já que neste casoa sentença não poderia prejudicar a terceiros, ou seja, se de improcedência, a sentença não poderia se tornar imutável para todos codetentores do direito, que não tiveram oportunidade de participação no processo.

Por outro lado, nas demandas individuais que versem sobre direitos indivisíveis, onde seja impossível a utilização da coisa julgada secundumeventum litis, já que, por exemplo, não há como se anular uma assembleia de sociedade anônima, se já houver sentença transitada em julgado declarando sua validade, a não ser que se acabe de uma vez com a própria coisa julgada, a conversão da demanda pseudoindividual em coletiva atribuirá plena legitimidade a toda amplitude subjetiva da coisa julgada ${ }^{395}$, já que é próprio do modelo coletivo de processo, um regime de coisa julgada diferenciado, que torne imutável a sentença judicial para todos codetentores do direito, quando este seja indivisível.

Admitir que issoocorra no processo individual é uma excepcionalidade, altamente nociva ao sistema, já que o modelo individual de processo não é recoberto das mesmas garantias que o processo coletivo, não sendo comum a participação obrigatória do M.P., nem a plena consciência sobre a repercussão que será proporcionada pela coisa julgadaou pela sentença que se baseia na insuficiência de provas, já que na maioria das vezes isto é ignorado no contraditório de demandas individuais.

Outrossim, alguns outros nuances, como os incontestáveis poderes instrutórios e a invariável publicação de editais para permitir maior participação, atribuem ao modelo coletivo de processo, um ambiente mais propicio ao alcance de uma decisão mais qualificada.

Não bastassem tais benefícios, pode-se dizer que outra vantagem da coletivização de demanda individual, que verse sobre direito indivisível, concerne à ampliação do objeto do processo, que ocorre quando a coisa julgada coletiva, envolvendo direito difuso ou coletivostricto sensu, é utilizada por indivíduos, que apenas liquidam e requerem a

\footnotetext{
${ }^{395}$ Aluísio Gonçalves de Castro MENDES. “A legitimação, representatividade adequada e a certificação nos processos coletivos e as ações coletivas passivas." Revista de Processo,p. 255.
} 
satisfação dos direitos individuais homogêneos a eles relacionados, de maneira similar ao que ocorre com o aproveitamento da coisa julgada penal no cível ${ }^{396}$.

Jamais se poderia falar, por exemplo, que uma ação individual, por meio da qual se determinasse o desligamento de uma chaminé industrial poluidora, fosse aproveitada por indivíduos que tenham sofrido danos individuais decorrentes de tal poluição.

Mas é plenamente possível que tal aproveitamentoin utilibus ocorra em se tratando de uma sentença semelhante, proferida numa demanda coletiva.

Desse modo, pensa-se que esses dois fundamentos, ligados a uma diferenciação do regime de coisa julgada do processo individual e do coletivo, e a uma diferenciaçãoda amplitude objetiva da sentença proferida numa demanda individual e numa coletiva, justifiquem a coletivização de demandas individuais, que versem sobre direitos indivisíveis, seja por que tais diferenças proporcionam uma redução no numero de processo e na sua complexidade, seja porque proporcionam maior harmonia e segurança ao evitar, com legitimidade e observância dos direitos fundamentais, conflitos práticos, não sendo aparentes, desvantagens suficientes capazes de infirmar os benefícios mencionados.

\section{A COLETIVIZAÇÃO DE DEMANDAS VERSANDO SOBRE DIREITOS INDIVIDUAIS HOMOGÊNEOS}

\subsection{Uma visão ampliada dos direitos individuais homogêneos e a decisão que converte uma ação individual em coletiva}

\footnotetext{
${ }^{396}$ GRINOVER, op. cit. p. 20, nota 394.
} 
Uma questão secundária, mas que mostra grande importância no estudo ora desenvolvido, concerne ao correto significado do termo: direitos individuais homogêneos, pois, dependendo da abrangência que se dará a este, se terá mais ou menos hipóteses de coletivização de demandas individuais.

Basicamente, os posicionamentos divergem entre aqueles que entendem pela restrição de tal significado, de modo que ele não abranja todas as lides com origem comum, mas somente aquelas que possuam preponderância de questões comuns, e aqueles que enxergam em tal conceito uma abrangência maior, de modo a envolver todos os direitos com origem comum, o que se coaduna ao nosso posicionamento, conforme passa a ser visto nos tópicos que seguem.

\subsubsection{O significado do termo homogêneo}

Não obstante o CDC, em seu art. 81, Par. Único, inciso III, defina os direitos individuais homogêneos como sendo aqueles de origem comum, autores complementam tal conceituação, afirmando que apenas são homogêneos os direitos que, além da origem comum, possuem ainda uma predominância de questões comuns. ${ }^{397}$.

Conforme se pode observar, para parcela da doutrina, não basta haver origem comum para que a homogeneidade dos direitos individuais reste configurada, sendo necessária, que haja também, nos casos concretos, uma prevalência das questões comuns sobre as individuais, a justificar a tutela coletiva do respectivo direito, o que, em verdade, deriva do direito americano, berço das classactions for damages e que vê, no requisito mencionado, um pressuposto lógico para a existência da superioridade da tutela coletiva

\footnotetext{
${ }^{397}$ Ada Pelegrini GRINOVER. Das classaction fordamages à ação de classe brasileira:os requisitos de admissibilidade.Revista Forense,p. 10. Segundo a autora: "Parece evidente, no entanto, que a origem comum - sobretudo se for remota - pode não ser suficiente para caracterizar a homogeneidade. No consumo de um produto potencialmente nocivo, não haverá homogeneidade de direitos entre um titular que foi vitimado exclusivamente por esse consumo e outro, cujas condições pessoais de saúde lhe causariam um dano físico, independentemente da utilização do produto ou que fez deste uso inadequado. Não há homogeneidade entre situações de fato ou de direito sobre as quais as características pessoais de cada um atuam de modo completamente diferente".
} 
sobre a individual, outro requisito a ser observado para a admissão da demanda coletiva, visando à tutela de direitos individuais naquele país ${ }^{398}$.

Em diversas decisões, os Tribunais americanos vêm inadmitindo classactions for damages, principalmente nos casos de danos causados por vício do produto ${ }^{399}$, onde as idiossincrasias individuais podem ser determinantes no resultado de um processo, o que retiraria a eficácia e a utilidade de uma hipotética decisão coletiva ${ }^{400}$, pois, mesmo após uma sentença reconhecer o dever de indenizar, o que poderia demorar muito, o nexo de causalidade ainda teria que ser demonstrado individualmente e, diga-se de passagem, mediante complexos procedimentos periciais, o que geraria ainda mais atrasos.

O argumento acima parece muito razoável e fundado em fortes digressões pragmáticas, todavia, mostra-se imprescindível, ainda que somente para suscitar um importante debate, sem grandes pretensões de infirmar o conceito de homogeneidade predominante, que sejam feitos os seguintes questionamentos: porque um processo que apenas assenta uma premissa maior e genérica, sem maiores demonstrações sobre a causalidade individual do dano, seria inútil? Será que não haveria nenhum aproveitamento dos atos praticados em seu âmbito? Será que tal aproveitamento não poderia tornar desnecessárias, milhares de reproduções do mesmo ato, trazendo assim, mesmo que de maneira diminuta, uma economia de tempo e dinheiro? Será que em um país como o Brasil, onde os direitos de massa carecem tanto de proteção em decorrência de inúmeros fatores, tais como econômico, cultural, entre outros, o entendimento norte-americano deve prevalecer?

Antes de se adentrar ao tópico seguinte, faz-se relevante somente uma explicação, que justifica a opção americana no tratamento dos direitos individuais homogêneos, qual seja: nos Estados Unidos, as indenizações são fixadas no próprio processo coletivo, para toda a classe ou com alguns ajustes para certos segmentos dela, e não mediante processos de liquidação individuais como no Brasil, sendo certo que, por isto, o procedimento de "liquidação" lá é diferenciado, admitindo-se no máximo uma distinção entre grupos da mesma classe ${ }^{401}$.

\footnotetext{
${ }^{398}$ Ibid., p. 5.

${ }^{399}$ Ibid., p. 7.

${ }^{400}$ Ibid., p. 7-9.

${ }^{401}$ Cássio Scarpinella BUENO. As classactions norte-americanas e as ações coletivas brasileiras:pontos para uma reflexão conjunta. Revista de Processo, São Paulo, n. 82, p. 92-151, abril-junho de 1996, p.
} 
Nota-se assim, que nos EUA, a sentença de liquidação é una, não havendo processos de liquidação distintos e individuais como no Brasil, concluindo-se, portanto, que o procedimento estabelecido para fixação das indenizações individuais justifica a opção dos norte-americanos por um conceito tão rígido de homogeneidade - o que não é o caso do Brasil.

No ensejo, deve ser feito o registro de que, nos EUA, mesmo diante do óbice procedimental existente, ainda assim, algumas demandas coletivas envolvendo direitos individuais supostamente "heterogêneos" têm sido admitidas, o que se iniciou principalmente a partir de meados dos anos 80, com o exame de casos envolvendo o "Agente Laranja" - produto químico utilizado na guerra do Vietnã e que trouxe diversos danos aos militares e seus familiares ${ }^{402}$.

Analisando esses exemplos, especialmente o mencionado na nota de rodapé, percebe-se como o alargamento da via das ações coletivas para proteção de direitos individuais homogêneos pode ser eficaz, já que, caso contrário, mais de 87.000 pessoas entrariam com demandas individuais, onde se discutiria além do dano, sua extensão e o nexo causal, a nocividade do amianto e a sua capacidade de produzir certos malefícios específicos no corpo humano.

Conclui-se assim, que não é tão escorreita a afirmativa concernente à suposta inefetividade de ações coletivas para a proteção de direitos individuais sem predominância de questões comuns, que só possuam em comum a origem, sem a prevalência de questões comuns, o que será mais profundamente discutido nos tópicos seguintes.

\footnotetext{
113.Segundo o autor: "Nestes casos, os Tribunais podem assumir três diferentes tarefas tendo em vista o acolhimento do pedido formulado. Devem resolver sobre a responsabilidade do réu, calcular o montante de danos sofridos à (ou pela) classe litigante, e, por fim, distribuir aos (ou cobrar dos) membros da classe, enquanto indivíduos que são, sua proporção exata na quantificação do dano. Pra tanto, é bastante comum que, para a consecução de um ou de outra destas etapas, haja necessidade de fragmentação ou individualização da classe". No mesmo rumo: GRINOVER, op. cit. p. 6, nota 396. A autora complementa, ensinando que: "numa etapa posterior, passa-se à liquidação dos danos, culminando na sentença final de liquidação".

${ }^{402}$ Sérgio Cruz ARENHART. A tutela de direitos individuais homogêneos e as demandas ressarcitórias em pecúnia.In: Ada Pellegrini GRINOVER; Aloisio Gonçalves de Castro MENDES; Kazuo WATANABE (Coord.). Direito processual coletivo e o anteprojeto de código brasileiro de processos coletivos, p. 219. O autor noticia ainda que: "Notabiliza-se, na jurisprudência recente dos Estados Unidos, o caso envolvendo as vítimas do amianto (que ultrapassam o número de 87.000), cujas pretensões indenizatórias foram tratadas de diversas formas na evolução da jurisprudência americana a respeito da ação de classe, sendo um dos ícones na atual tendência à admissão da tutela coletiva de interesses indenizatórios".
} 


\subsubsection{A maior eficiência mesmo nas hipóteses de direitos sem a predominância de questões comuns}

Para aqueles que refutam a utilidade das ações coletivas para a proteção de direitos individuais que, apesar de terem a mesma origem, supostamente não são homogêneos, por não possuírem predominância de questões comuns, o principal argumento centra-se na efetividade e economia processual ${ }^{403}$.

Para essa vertente, um processo coletivo envolvendo direitos individuais sem a predominância de questões comunspoderia ser ineficaz, não se prestando aos fins inerentes ao processo judicial, de pacificação social com a resolução da crise de direito material ${ }^{404}$, o que, todavia, tentar-se-á demonstrar adiante, que não é bem assim.

Parece irrefutável, de fato, que, quanto menor a predominância de questões comuns em um processo coletivo, que vise à tutela de direito individuais, menor será a eficácia da sentença proferida em seu bojo, o que, todavia, não significa dizer que a mesma será totalmente ineficaz e, por isto, vedada no ordenamento jurídico brasileiro ${ }^{405}$.

Para que se torne mais tangível a conclusão ora defendida, permita-se a visualização de um exemplo, similar ao que fora utilizado em outro texto para justificar posição distinta da presente ${ }^{406}$ : imagine que tenha sido ajuizada uma ação coletiva, visando à reparação dos danos causados pelo uso de um produto; na ação, articula-se o argumento de que tal produto é nocivo à saúde, tendo causado danos a inúmeras pessoas, e que tal informação não fora divulgada pelo fabricante.

Bem, com base nas regras do ônus da prova, será imprescindível a realização de uma perícia, apta a comprovar a alegação de que o produto em questão causa mal a saúde; realizada a referida perícia e constatada a alegada nocividade, é proferida sentença

\footnotetext{
${ }^{403}$ Ada Pelegrini GRINOVER. Das classaction fordamages à ação de classe brasileira:os requisitos de admissibilidade.Revista Forense,p. 11 e 13. Na página 11 a autora afirma que: "Ora, a prova do nexo causal pode ser tão complexa no caso concreto, que tornará praticamente ineficaz a sentença condenatória genérica do art. 95, a qual só reconhece a existência do dano geral. Nesse caso, a vítima ou seus sucessores deverão enfrentar um processo de liquidação tão complicado quanto uma ação condenatória individual, até porque ao réu devem ser asseguradas as garantias do devido processo legal, e notadamente o contraditório e a ampla defesa. E a via da ação coletiva terá sido inadequada para a obtenção da tutela pretendida”.

${ }^{404}$ Ibid., p. 13.

${ }^{405}$ Ibid., p. 10-11.

${ }^{406}$ Ibid., p. 12.
} 
genérica, na qual se condena o fabricante do produto a indenizar os consumidores, pelos danos causados.

Segundo a corrente doutrinária ora enfocada, um caso como este jamais seria tutelável mediante uma ação coletiva, pois as questões individuais se sobreporiam as coletivas, já que seria possível a formulação de exceções pessoais ${ }^{407}$, fundadas, por exemplo: no conhecimento da nocividade do produto, na pré-existência de doenças ou numa pré-disposição genética, no uso de outros produtos com o mesmo componente nocivo, entre outros ${ }^{408}$, o que, ao final, obrigaria uma liquidação com provas periciais de altíssima complexidade a serem produzidas, demandando muito tempo e retirando, com isto, toda a efetividade do processo coletivo ${ }^{409}$.

Em contrapartida, parece que algumas benesses advirão sim do processo coletivo ora comentado, em prol dos indivíduos afetados pelo produto nocivo, sendo que tal afirmativa pode ser propalada com base em diversos motivos.

Inicialmente, o primeiro benefício perceptível no caso em exame, é a fixação de uma premissa maior, em decorrência do processo coletivo, a partir da qual todos os casos concretos, que se subsumirem a ela, serão resolvidos do mesmo modo, ou seja, a partir do referido processo coletivo não se discutirá mais em nenhuma liquidação, a nocividade do produto em questão, possuindo a sentença coletiva efeito semelhante ao de uma lei.

Neste sentido, cumpre reprisar que tal premissa já fundada, evita que nas liquidações individuais se retome a discussão sobre a questão por ela respondida e, consequentemente, dispensa que cada indivíduo produza prova pericial sobre a nocividade do produto em questão, ou seja, milhares de provas periciais podem ser evitadas pela fixação da premissa maior mencionada, o que só será feito por meio de um processo coletivo.

Em caso de inexistência do referido processo coletivo, ou seja, caso cada indivíduo tivesse que demandar em juízo para comprovar a nocividade do produto objeto da ação coletiva, teria cada um de produzir uma prova pericial no seu processo individual.

Obviamente, tal obstáculo poderia ser ultrapassado com o instituto da prova emprestada, todavia, nem sempre uma pessoa comum ou o seu advogado teriam meios de

\footnotetext{
${ }^{407}$ Ibid., p. 4.

${ }^{408}$ Ibid., p. 12.

${ }^{409}$ Ibid., p. 13.
} 
obter a prova já produzida em outro processo, sendo certo, também, que dificilmente o fabricante do produto requereria a juntada de tal prova, se a mesma tivesse conteúdo desfavorável a ele, o que, ainda que fosse feito, não vincularia o magistrado.

Percebe-se assim, que a premissa genérica firmada no processo coletivo em exemplo, apesar de "menos" eficiente que o almejado pela doutrina, possibilitaria a não repetição do mesmo ato em inúmeros, talvez milhares de processos.

Como corolário de tal situação, não há como se negar, que uma quantia significativa de dinheiro seria economizada, seja por parte do consumidor, seja por parte do Réu - em caso de inversão do ônus da prova ${ }^{410}$, o que, permita a descontração, só não seria bom para os peritos.

Não bastasse a economia de atos processuais e de dinheiro mencionadas, há que se salientar, ainda, outro argumento, relativo à redução do tempo dos processos individuais, o que seria uma consequência lógica da redução de atos processuais.

Se em um processo era necessária a realização de duas perícias, como no exemplo retro formulado, uma para se constatar a nocividade do produto e, outra, para se constatar o nexo causal, com o manejo ampliado da ação coletiva, só seria exigível a realização da perícia para demonstração do nexo causal, o que geraria uma economia de tempo no processo específico e, por efeito cascata, em todos os outros processos que concorressem à um julgamento com aquele específico, principalmente se pensado for, que, ao invés de uma perícia para comprovar a nocividade do produto, com a demanda coletiva em estudo poderia se impedir a realização de milhares de pericias em todo o Brasil, para a obtenção da mesma conclusão, ou seja, milhares de processos poderiam ter seus cursos acelerados, o que traria um reflexo positivo inexorável para os demais processos em trâmite, ainda que alheios a demanda coletiva.

Outrossim, a ação coletiva versando sobre direitos individuais sem predominância de questões comuns teria como virtude, ainda, ao fixar a premissa maior referida nos parágrafo anteriores, proporcionar maior segurança jurídica aos jurisdicionados.

Isto porque tornaria impossível, ao menos em tese, em virtude dos seus efeitos erga omnes, uma decisão que contradissesse tal premissa, nos mais diversos casos individuais, ou seja, evitaria que uma demanda fosse julgada procedente, por reconhecer a nocividade

\footnotetext{
${ }^{410}$ Eduardo CAMBI. A prova civil,p. 410-412.
} 
do produto e o nexo causal, e outra fosse julgada improcedente, por entender que o produto não é nocivo à saúde, o que, felizmente ou não, é plenamente possível no modelo doutrinário ora discutido, que prima pelas demandas individuais.

Além dos fundamentos supra, resta ainda consignar, que uma ação coletiva envolvendo direitos sem predominância de questões comuns, teria ainda uma função educadora, ou melhor, de conscientização, já que a maior parte da população não tem qualquer informação sobre a vastidão e a amplitude dos direitos próprios e alheios, nem dos meios para efetivá-los ${ }^{411}$, o que seria colocado em mais evidência, permitindo assim um maior acesso à justiça, em termos quantitativos, se alargada fosse à via das ações coletivas para proteção de direitos individuais.

Por fim, além da falta de informação, deve-se alertar ainda para a falta de recursos financeiros suportada pela população, que fica impedida de contratar profissionais e mais, profissionais de boa qualidade, que tenham a real noção da importância da função que exercem e que tenham conhecimentos profundos sobre o direito, o que, na verdade, se mostra como mais um dos fundamentos a justificar a dilação da via das ações coletivas para proteção de direitos individuais.

A carência financeira da maior parte da população pode ser invocada também, com base nos custos inerentes a produção de prova pericial, o que, apesar de ser passível de inversão, poderia gerar muitos problemas, pois a inversão possui alguns requisitos, que nem todos os magistrados poderiam considerar preenchidos nos diversos casos concretos $^{412}$, o que às vezes, causaria o entupimento dos Tribunais com recursos - mais do que já estão, sendo certo ainda, que existem correntes, a defender que a inversão só é cabível em caso de relação de consumo ${ }^{413}$, além dos que falam que a inversão do ônus da prova não significa inversão do custo da perícia ${ }^{414}$, o que, em verdade, em muitos casos esvazia o próprio sentido de tal técnica, mas sem dúvida alguma, traria muitas decisões paradoxais.

\footnotetext{
${ }^{411}$ Candido Rangel DINAMARCO. A instrumentalidade do processo,p. 224-225.

${ }^{412}$ Eduardo CAMBI. "Divergência jurisprudencial:inversão do ônus da prova e o ônus de antecipar o pagamento dos honorários periciais."Revista Sintese de Direito Civil e Processual Civil, p. 17-18.

${ }^{413}$ CAMBI, op. cit. p. 422-426, nota 410.

${ }^{414}$ CAMBI, op. cit. p. 18-22, nota 412.
} 
Todos os argumentos ora explanados, apesar de serem passíveis de ponderação como qualquer outro argumento $^{415}$, se encontram em total consonância com os escopos ${ }^{416} \mathrm{e}$ princípios do processo, principalmente os do processo coletivo. ${ }^{417}$

Dentre os princípios que respaldam o posicionamento ora adotado, não parece demasiado lembrar o principio da universalidade da jurisdição, reconhecido por Grinover como ligado ao princípio do acesso à justiça ${ }^{418}$.

Como se pode perceber, somente com o manejo mais amplo das demandas coletivas é que o direito fundamental de participação ${ }^{419}$ e acesso à justiçą ${ }^{420}$ do individuo será integralmente preservado, pois as ações coletivas para a proteção de direito individuais permitem uma divulgação muito mais ampla da existência do direito e da sua tutela, fazendo com que os mais humildes tenham um real acesso à justiça e cumprindo com o escopo social e jurídico do processo $^{421}$, sem falar no prestigio ao princípio da econômica processual que isto traz ${ }^{422}$, ainda que seja somente para evitar a repetição de atividades instrutórias sobre questões idênticas.

\subsubsection{A técnica de ampliação objetiva da demanda coletiva e sua relação com uma compreensão mais abrangente do termo homogêneo}

\footnotetext{
${ }^{415}$ Samuel Meira BRASIL JÚNIOR. Justiça, direito e processo. A argumentação e o direito processual de resultados justos, p. 104.

${ }^{416}$ DINAMARCO, op. cit. p. 207-215, nota 411.

${ }^{417}$ Elton VENTURI. Processo civil coletivo: a tutela jurisdicional dos interesses difusos, coletivo $e$ individuais ..., p. 135-161.

${ }^{418}$ Ada Pelegrini GRINOVER. "Direito Processual Coletivo." In: ___ _ Aluisio Gonçalves de Castro MENDES; KazuoWATANABE (Coord.). Direito processual coletivo e o anteprojeto de código brasileiro de processos coletivos, p. 12. Para a autora, a universalidade da jurisdição: "[...] assume dimensão distinta no processo coletivo, pois é por intermédio deste que as massas têm a oportunidade de submeter aos tribunais as novas causas, que pelo processo individual não tinham sequer como chegar a justiça. $\mathrm{O}$ tratamento coletivo de interesses e direitos comunitários é que efetivamente abre as portas à universalidade da jurisdição".

${ }^{419}$ Luiz Guilherme MARINONI. Curso de Processual Civil: Teoria Geral do Processo, p. 430.

${ }^{420}$ Ibid., p. 204-205.

${ }^{421}$ DINAMARCO, op. cit. p. 233-234, nota 411.

${ }^{422}$ GRINOVER, op. cit. p. 13, nota 418.
} 
Não bastassem todos os fundamentos articulados acima, no sentido de tentar ampliar a compreensão do termo homogêneo e, consequentemente, a via da ação coletiva para a proteção de direitos individuais, deve-se alertar ainda para o seguinte fato: a restrição causada pela interpretação diminuta do termo homogêneo deverá resultar inócua, na maior parte dos casos, já que poderá ser burlada por meio de demandas que, diante da vedação ora discutida, objetivarão a proteção de direitos difusos ou coletivos stricto sensu, gerando, da mesma forma, os efeitos individuais benéficos, que poderiam ter sido gerados por uma demanda coletiva para a proteção de direito individuais sem predominância de questões comuns.

Esta afirmação pode soar um tanto quanto improvável, todavia, com o mesmo exemplo citado no tópico acima, é possível se comprovar tal afirmativa, senão observe: ao invés de ser ajuizada uma ação para proteção de direitos individuais sem predominância de questões comuns, para indenização dos consumidores lesados pelos malefícios do produto comercializado, o ente legitimado, sabendo de uma possível barreira que poderia encontrar, ajuíza uma ação visando à tutela de direitos difusos, bastando que, para tanto, ao invés de se requerer a indenização do lesados, se requeira a condenação do fabricante na obrigação de informar aos consumidores, sobre os riscos decorrentes do uso do produto.

Sendo produzida a prova pericial, que determine a nocividade do produto, e sendo proferida sentença, que obrigue o fabricante a informar aos consumidores sobre os riscos decorrentes da utilização do produto, os indivíduos, nas suas respectivas demandas individuais poderão, por força do artigo $103, \S 3 .^{\circ}$ do CDC, se aproveitar da condenação referida, o que significa dizer, que a prova sobre os malefícios do produto será dispensada nas demandas individuais de liquidação que surgirão; pode soar estranho, mas é o próprio código que fala da possibilidade de se iniciar a liquidação, com base na coisa julgada formada no processo coletivo que verse sobre direitos difusos ou coletivos stricto sensu.

Perceba desta forma a contradição: não obstante a doutrina entenda por ineficaz uma ação coletiva para a proteção de direito individuais sem predominância de questões comuns, o próprio diploma consumerista autoriza a liquidação individual das sentenças proferidas em ações versando sobre direitos difusos e coletivos, por considerar eficaz tais sentenças, que reduzirão o campo cognitivo do magistrado nas respectivas liquidações.

Após tal constatação, deve-se consignar que, no que tange ao fato da coisa julgada produzida em processos coletivos envolvendo direitos individuais homogêneos beneficiar os indivíduos, não há que se falar em qualquer surpresa, mesmo porque, este é justamente 
o principal propósito de tais demandas, que têm como objeto justamente a indenização de todos os lesados pela conduta omissiva ou comissiva da parte contrária.

Todavia, o fato da coisa julgada produzida em processo coletivos, envolvendo direitos difusos e coletivos stricto sensu, ser estendida para beneficiar as causas individuais, fundadas no mesmo ato constritor de interesses transindividuais gera, ao menos a priori, uma sensação de novo, tendo em vista, que experiência igual somente se vislumbrava quando do aproveitamento da coisa julgada produzida na esfera penal, transportando-a para a esfera cível.

Para se conferir maior palpabilidade às hipóteses concernentes a ações coletivas envolvendo direitos transindividuais, em que se mostra altamente eficiente o transporte da coisa julgada positiva em prol de demandantes individuais, justificando-se, assim, a respectiva técnica, pode ser concebido o seguinte exemplo, envolvendo um interesse difuso hipoteticamente violado por uma empresa, que despeja dejetos em um rio, degradando, com isto, a flora e a fauna que circundam e dependem deste rio, além da população ribeirinha, que consome a respectiva água e os animais que nela habitam.

Diante de tal quadro, ajuíza-se uma ação coletiva para a proteção do meio ambiente, cujo pedido visa somente à interrupção da poluição, por meio de qualquer medida apta a alcançar este resultado, bem como a restauração da degradação promovida pela poluição despejada pela empresa requerida.

Ressalte-se, que muitas vezes, para os ribeirinhos prejudicados com tal poluição, que tenham padecido com doenças ou até lucros cessantes decorrentes da redução da pesca, seria muito difícil iniciar e prosseguir até o fim em uma ação individual contra a empresa poluidora, normalmente bem estruturada economicamente e instruída juridicamente, motivo pelo qual, a demanda coletiva acima mencionada pode apresentar-se como único meio, às vezes, de auxilio na efetivação dos seus direitos individuais que vêm sendo violados.

Neste contexto, julgada procedente a demanda, a empresa será condenada a parar de despejar detritos no rio, além de ser condenada a restaurar o meio-ambiente ali degradado; observe que a hipotética sentença de procedência, envolvendo interesses difusos, ajudará em muitos os ribeirinhos que tenham ingressado ou venham a ingressar com demandas individuais reparatória de danos pessoais, pois permitirá que estas já partam 
da premissa da existência do ato danoso poluidor, que deverá agora, apenas ser conectado ao caso concreto e quantificado, a fim de que haja uma justa reparação.

Nota-se assim, que grande parte da complexidade que permeia qualquer demanda judicial e que obriga as partes a produzirem prova pericial, com debates técnicos, já terá sido resolvida pela coisa julgada concebida no processo coletivo.

Foi essa a visão do legislador, quando fez constar do diploma consumerista, previsão expressa da técnica em estudo, devendo essa visão, por consequência lógica, autorizar também o manejo de ações coletivas para a proteção de direito individuais, que só possuam uma origem comum, sem a predominância de questões comuns, pois a eficácia dela será igual à já reconhecida às sentenças positivas, proferidas em demanda coletivas que versem sobre direitos difusos e coletivosstricto sensu.

Percebe-se, por meio do exemplo mencionado, a importância do dispositivo em estudo, que constitui uma importante inovação do $\mathrm{CDC}^{423}$, ao prever a extensão dos benefícios da coisa julgada produzida no âmbito de uma ação coletiva ajuizada para a proteção de interesses difusos ou coletivos stricto sensu, para as ações indenizatórias individuais.

Percebe-se também, que a ação utilizada no exemplo, pode ser vista, de maneira complementar, como um meio de auxilio na obtenção da tutela individual, sendo tal finalidade uma decorrência do princípio da máxima interação entre as tutelas coletivas e individuais.

Outrossim, se mantida a mentalidade ora discutida, sobre a compreensão restritiva do termo homogêneo contido na lei, perceber-se-á que o exemplo dado, também servirá como meio de se burlar o controle de admissibilidade de demandas coletivas, porque, se no caso do exemplo, o magistrado não admitisse uma ação coletiva que visasse a reparação individual dos danos decorrentes da poluição, bastaria que o autor mudasse a causa de pedir e os pedidos, para, da mesma forma, beneficiar os indivíduos ribeirinhos prejudicados com a poluição, sendo que a coisa julgada produzida nessa ação, se não tivesse eficácia prática e real sobre as demandas individuais.

Para findar o presente debate, cumpre registrar, que o fenômeno ora analisado necessita ser compreendido não só por meio de ilustrações práticas, mas também,

\footnotetext{
${ }^{423}$ Ada Pelegrini GRINOVER; Nelson NERY JÚNIOR; KazuoWATANABE, Kazuo; et al. Código Brasileiro de Defesa do Consumidor:comentado pelos autores do anteprojeto, 9.ed. p. 911.
} 
teoricamente, à luz do instituto da extensão ope legis do objeto do processo, para incluir na coisa julgada a decisão sobre o dever de indenizar ${ }^{424}$.

Conforme se observa, o fenômeno em questão, de extensão in utilibus da coisa julgada coletiva envolvendo direito difuso ou coletivo stricto sensu, em favor delitigantes individuais, decorre de uma ampliação determinada por lei, do objeto do processo coletivo, que, se julgado procedente, passa a abranger o dever de o réu indenizar os indivíduos lesados pelo mesmo ato que lesou os interesses difusos tutelados em espécie.

Neste sentido, cumpre-se apenas reprisar, que tal técnica se encontra em total consonância com o princípio da economia processual ${ }^{425}$, vez que impede a prática de atos desnecessários, já praticados com idêntica finalidade em processo distinto, reduzindo-se, assim, o tempo e o custo do processo individual, o que a torna plenamente compatível, também, com o princípio da razoável duração do processo, da instrumentalidade do processo $^{426}$ e do acesso à justiça, visto como um direito fundamental sob o paradigma constitucional do Estado Democrático de Direito ${ }^{427}$.

\subsubsection{A decisão que coletiviza ação individual versando sobre direitos individuais homogêneos}

De maneira similar ao que foi falado no tópico sobre a decisão que coletiviza demanda individual, que verse sobre direito indivisível, a decisão que coletivize demanda

\footnotetext{
${ }^{424}$ Ada Pelegrini GRINOVERet al. Código brasileiro de defesa do consumidor: comentado pelos autores do anteprojeto.8. ed. p. 911. Para a autora: "Trata-se de fenômeno conhecido, mas até agora restrito, no nosso ordenamento, aos efeitos civis da sentença penal condenatória: nos termos do art. 91, I, CP, a condenação penal torna certa a obrigação de indenizar os danos causados pelo crime, passando-se desde logo à liquidação e execução da sentença no juízo civil (arts. 63, CPP e 584, II, CPC). Exatamente o mesmo fenômeno ocorre agora, por força do Código de Defesa do Consumidor, quanto à sentença favorável coletiva, a ser imediatamente liquidada e executada com relação aos danos sofridos pelas pessoas individualmente lesadas."

425 Ibid., p. 934.

${ }^{426}$ Candido Rangel DINAMARCO. A instrumentalidade do processo,p. 206-207.

${ }^{427}$ Luiz Guilherme MARINONI. Curso de Processual Civil: Teoria Geral do Processo,p. 204-205.
} 
individual, mas que verse sobre direitos individuais homogêneos, deverá observar os mesmos pontos fundamentais.

Nesse sentido, mostra-se imprescindível que, primeiro, o magistrado identifique se o direito individual em questão é efetivamente homogêneo, ou seja, possui origem comum em relação a outros direitos individuais, ainda que essa comunidade de origem não se baseie em um único fato ${ }^{428}$, momento em que deverá observar os pontos definidos no tópico sobre a decisão que converte demanda individual em coletiva.

Outrossim, deverá o magistrado analisar se o uso do modelo coletivo de processo se justifica, ou se o numero de pessoas envolvidas na situação comportaria uma tutela individual na forma de litisconsórcio.

Por fim, caberá ao magistrado analisar, se o autor da demanda individual tem legitimidade processual, ou seja, se ele participa da relação material que consubstancia sua causa de pedir, pois do contrário, ou seja, se lhe faltar legitimidade ad causam, não haverá como se falar em legitimidade para a demanda coletiva, num raciocínio que se aproxima muito da logica definida na rule 23 , que exige que o representante da coletividade faça parte da classe ${ }^{429}$.

Quando o magistrado se propuser a analisar a natureza do direito em litigio, para concluir se se trata ou não de um direito coletivo ou que possa ser tratado coletivamente, deverá ele avaliar, primeiramente, se a situação fática, na qual se insere o direito alegado, propicia a existência de um numero maior de pessoas em situação similar, o que ele deverá constatar, com base num juízo de probabilidade, ou seja, lastreado no que normalmente acontece, com o auxilio do instituto jurídico das máximas de experiência ${ }^{430}$.

Não ficará o juiz adstrito, para constatar a homogeneidade do direito, à existência de demandas similares, onde se pretendam direitos individuais com a mesma origem.

Aliás, parece notoriamente deficiente uma técnica que, primando pela celeridade e economia processual, obrigue milhares de indivíduos a entrar com suas demanda

\footnotetext{
${ }^{428}$ KazuoWATANABE et al.Código brasileiro de Defesa do Consumidor: comentado pelos autores do anteprojeto, 6. ed.p. 724.

${ }^{429}$ Jack H. FRIEDENTHAL; Mary Kay KANE; Arthur R. MILLER.Civil Procedure,p. 727.

${ }^{430}$ Sobre o uso de máximas de experiência no processo civil: Michele TARUFFO. "Senso comune, esperienza e scienzanelragionamentodelgiudice."In: Sui confini: scrittisullagiustiziacivile, p. 140145.
} 
individuais, para só a partir daí se poder constatar a homogeneidade do direito e se proporcionar a tutela ao individuo.

O processo coletivo pressupõe justamente, que o individuo não precise demandar em juízo, pois esta é a premissa para que se reduzam o número de demandas e, com isto, se otimize a atividade desempenhada, dotando-a de maior qualidade e eficácia, resultados que são prejudicados pelo número excessivo de processos aguardando julgamento parecidos.

Quando o sistema obriga que a pessoa entre com sua demanda individual, para que fique caracterizada a homogeneidade do direito e se distribua a tutela por meio de um julgamento uniforme, se impõe, desnecessariamente, quemilhares de pessoas ingressem com suas iniciais, para somente depois se tomar uma providencia.

Em verdade, o raciocínio deve ser preventivo, ou seja, devemos pensar em técnicas que previnam o ajuizamento de milhares de demandas, evitando-o, e não que exijam tal situação.

Ainda que se argumente, que mesmo no modelo coletivo o ajuizamento de ações individuais seria inevitável em algum momento, em decorrência da necessidade de liquidação e execução individual dos direitos reconhecidos, sabe-se, por outro lado, que alguns direitos individuais homogêneos não precisaram de liquidação e execução, quando satisfeitos por tutelas declaratórias e constitutivas.

Outrossim, no tópico abaixo discutiremos novas técnicas, que podem promover a redução do numero de liquidações e execuções individuais, mesmo em se tratando de tutelas condenatórias, o que será melhor discutido adiante.

Por fim, deve-se registrar ainda, que as milhares de liquidações e execuções individuais só surgirão se o direito individual for efetivamente reconhecido e mais, propiciarão muito menos complexidade às partes e ao Judiciário, do que o processamento de milhares de processo de conhecimento sobre a existência ou não de um direito, mesmo porque, sabe-se do grande percurso recursal que existe no sistema, e que é sentido em dobro, quando além de liquidar e executar um titulo, se tem que obter a sua constituição individualmente.

Desse modo, caberá ao magistrado, quando analisar a natureza do direito em litigio, apenas constatar se é provável, com base em máximas de experiência, que aquele direito se trate de um direito individual homogêneo, por abranger um numero provavelmente maior de pessoas, que se encontra em situação similar. 
As máximas de experiência, nada mais são do que aquilo que normalmente acontece e pode ser percebido por um homem médio, mediante um juízo de razoabilidade e não de certeza, que permita alcançar uma conclusão generalizante ${ }^{431}$.

Por exemplo, diante de uma demanda em que se discuta a validade de uma clausula constante em um contrato de adesão, relacionado a um serviço de crédito promovido por uma instituição financeira, onde se prevê a incidência de taxas abusivas para a hipótese de mora, pode-se concluir que um vasto número de pessoas se encontre em tal situação, já que os serviços de crédito são utilizados por uma parcela significativa da população, e o contrato de adesão possui um formato uniforme, que não é passível de conter particularidades.

Por outro lado, se a demanda versa sobre um dano decorrente de fato gerado pelo produto, dificilmente se poderá considerar como homogêneo tal direito, ao menos a priori, já que é razoável que apenas um único produto tenha vindo com defeito capaz de gerar o fato danoso.

Esses exemplos, obviamente, não tornam a situação simplória, mas demonstram que o reconhecimento da homogeneidade prescinde da existência de demandas similares.

Outro ponto a ser analisado com atenção, refere-se à justificativa para o trato coletivo da questão, já que nem sempre os direitos individuais homogêneos envolverão numero suficiente de pessoas, a justificar o uso da modelo coletivo de processo.

Dificilmente seria tangível o estabelecimento na lei, de um numero exato que defina quando será ou não conveniente o uso do processo coletivo no lugar do individual com litisconsórcio, tanto é assim, que ao estabelecer vedação ao litisconsórcio multitudinário, o legislador não fixou numero algum que caracterizasse tal anomalia.

Sendo assim, a análise da conveniência da demanda coletiva, com base na existência de numero suficiente de pessoas, que justifique a adoção do modelo coletivo de

\footnotetext{
${ }^{431}$ TARUFFO, op. cit. p. 141, nota 430. Segundo o autor: “[...], lamassima d'esperienza e una regolagenerale que vienecostruitainduttivamentesulla base dell'esperienza relativa a determinatistatidi cose. Questaregolapuoesserepoiimpiegatadalgiudice come critério per fondare i suoiragionamenti: essendo una regolagenerale, essa serve al giudice come premessamaggiore dei silogismi in cui si articolail suo ragionamento". EM português: "[...], a máxima de experiência e uma regra geral que é construída indutivamente sobre uma experiência relativa à determinados estados de coisas. Essa regra pode ser empregada pelo juiz como critério para fundar suas decisões: sendo uma regra geral, ela serve ao juiz como premissa maior dos silogimos nos quais se articula sua decisão".
} 
resolução de conflitos, dependerá do tempo e do espaço no qual a decisão se situa, bem como dos precedentes que se estabelecerão ${ }^{432}$.

Estabelecido que se trata de um direito individual homogêneo, para o qual o uso do processo coletivo mostra-se conveniente, deverá o juiz analisar se o autor da demanda individual está legitimado para ela, por fazer parte da relação jurídica material que consubstancia a causa de pedir.

Havendo a legitimidade ad causam, por tudo que foi dito, pode-se considerar que o autor da demanda representará a classe de pessoas portadora de direito similar, daí em diante com a participação do Ministério Publico, que, como visto, poderá se litisconsorciar à demanda, com uma maior preocupação do juiz com a direção do processo, para que omissões e formalismos não prevaleçam e nem prejudiquem a justiça da decisão, e com a convocação de interessados a participação, respeitada a inviabilidade do litisconsórcio multitudinário.

Convertida a ação individual em coletiva, a coisa julgada poderá beneficiar todo grupo de pessoas que possuam direito individual semelhante, baseado em origem comum, sem poder prejudicá-los, ressalvados aqueles que atuarem como litisconsortes.

\subsection{A molecularização das lides individuais e o problema das liquidações e execuções atomizadas}

Uma grave crítica que pode ser feita ao processo coletivo e àqueles que defendem a ampliação do seu uso, concerne ao fato da técnica processual coletiva no Brasil, especificamente nos casos envolvendo direitos individuais homogêneos, ainda não ter alcançado um grau satisfatório de utilização e efetividade, por causa da necessidade, em

\footnotetext{
${ }^{432}$ Segundo o autor CASSIO SCARPINELLA BUENO, a doutrina americana aponta para um numero entre vinte e cinco a quarenta pessoas, como sendo suficiente para justificar o modelo coletivo de resolução de conflitos. Cassio Scarpinella BUENO. "As classactions norte-americanas e as ações coletivas brasileiras: pontos para uma reflexão conjunta."Revista de Processo, p. 111.
} 
muitas dessas situações, de instauração de milhares de processos de liquidação e execução da sentença condenatória coletiva ${ }^{433}$, que é genérica nos termos do artigo 95 do CDC.

A necessidade de milhares de liquidações e execuções individuais, das sentenças condenatórias coletivas versando sobre direitos individuais homogêneos, de fato mina a técnica processual coletiva, na medida em que contradiz a sua característica fundamental, de molecularização das demandas.

Ainda que reste dispensada a liquidação de sentença coletiva que condene ao cumprimento de obrigação de fazer ou não fazer, relativa a direito individual homogêneo, o que decorre da natureza dessas obrigações, as execuções individuais persistem, de modo que cada indivíduo tenha de pleitear a satisfação do seu direito.

Isso é um prato cheio para aqueles que querem se opor à modificação do modelo de processo jurisdicional brasileiro, pois permite que se questione a eficiência de tal mudança, prejudicando a proposta presente nesta pesquisa, razão pela qual se mostra fundamental o enfrentamento desse ponto, na tentativa de se diagnosticar uma técnica adequada, que reduza a necessidade de liquidações e execuções individuais de sentenças condenatórias coletivas e, com isto, potencialize sua efetividade.

Nesse contexto, buscou-se no presente ensaio, uma resposta à seguinte questão: como se poderia reduzir a necessidade de processos de liquidação e execução individuais, na busca pela efetivação de direito individuais homogêneos reconhecidos em sentença coletiva condenatória?

Uma das propostas existentes, mas que não será objeto de adesão nesta pesquisa, é aquela que sugere a realização da liquidação no próprio processo coletivo, sempre que isto for viável, de maneira parecida com o que ocorre no direito norte-americano, para que se tenha uma sentença coletiva líquida ${ }^{434}$.

Essa técnica, prevista no anteprojeto do Código Brasileiro de Processos Coletivos, tornariam desnecessárias, milhares de liquidações individuais e, quem sabe, milhares de execuções individuais também, fazendo-se tudo de maneira coletiva, num suposto ambiente solidarista.

\footnotetext{
${ }^{433}$ Sergio Cruz ARENHART; Aluísio Gonçalves de Castro MENDES; Gustavo OSNA. "Cumprimento de sentenças coletivas: da pulverização à molecularização.” Revista de Processo,p. 60-61.

${ }^{434}$ Aparentemente nesse sentido, quando fala em "sentenças intrinsecamente executáveis": Ibid. p. 62.
} 
O refugo à proposta em questão se deve a inúmeros fatores, que não serão objeto de aprofundamento, para que se mantenha o foco.

Sem embargo, deve-se registrar que o maior fator de não aceitação do modelo norte-americano, refere-se ao fato da liquidação na fase de conhecimento não reduzir o trabalho proporcionado pela necessidade de aferição individual de relação jurídica entre o individuo e o condenado, mas apenas concentrar esse trabalho em um único procedimento, o que gera vários efeitos colaterais.

Ao proceder dessa maneira, a tutela coletiva também se deforma, perdendo parte do seu aspecto molecular e se aproximando do modelo atomizado, que se desenvolveu na tradição romano-germânica.

Ainda que não haja inúmeras liquidações individuais, na liquidação coletiva haverá uma complexidade similar à que se teria com a soma de todas aquelas; isto porque, todos os documentos que deveriam ser juntados e analisados em cada liquidação individual por artigos, serão juntados e analisados no processo coletivo, sob o jugo de um único magistrado e sob a atuação de alguns poucos advogados.

Também a execução coletiva, prevista no artigo 98 do CDC como possível mecanismo de aceleração da tutela, se mostrará um grande litisconsórcio, na medida em que a inicial será instruída com fatos e documentos individuais, passíveis de discussão individualizada nas impugnações, cabendo depois, o rateio do objeto da expropriação entre todos os indivíduos, nos casos envolvendo pagamento de quantia.

O que se pretende com a presente análise é a construção de uma técnica processual diferente, que dispense, ou ao menos reduza a própria necessidade de liquidação e execução dos direitos individuais homogêneos reconhecidos em sentença coletiva condenatória em sentido amplo, o que é diferente de propor a concentração do procedimento de liquidação e execução.

Destarte, buscar-se-á no desenvolvimento desta empreitada, uma forma de se proporcionar a satisfação de direito individual homogêneo reconhecido em sentença coletiva condenatória, sem a instauração de fase ou processo de liquidação individual ou coletiva, por se partir da premissa que a tutela jurisdicional coletiva ganhará em efetividade com isto.

Obviamente, essa técnica terá de se compatibilizar com as demais normas do sistema, não podendo ser um resultado a ser buscado a qualquer custo. 
Além disso, se tem a consciência de que em alguns casos a necessidade de liquidação, individual ou coletiva, será intransponível, quando as circunstancias fáticas especificas assim impuserem, seja porque o valor a ser restituído é apenas estimado pela parte - como nas indenizações por danos morais, dependendo de muitas nuances, ou mesmo por dependerem de provas individuais de danos emergentes e lucros cessantes decorrentes de ilícitos.

Assim, parece natural, que em uma demanda coletiva, onde se apurem eventuais danos pela contaminação decorrente do consumo de um produto será indispensável uma liquidação individual, que indique os valores que deverão ser pagos a titulo de danos morais e materiais.

Entretanto, existem demandas coletivas versando sobre direitos individuais homogêneos, que podem ser satisfeitos com a dispensa da liquidação e execução, apesar da natureza condenatória da sentença, e independentemente da natureza da obrigação.

Nos casos, por exemplo, em que o réu é condenado a não reajustar o valor de determinadas parcelas, a aplicar determinado índice no reajuste de contratos, a disponibilizar determinados serviços, a restituir a cobrança de determinada taxa ilegal, a pagar determinado direito a empregados ou a servidores, ou a cumprir qualquer outra prestação, desde que ele tenha como identificar os beneficiários da decisão e eventuais quantias envolvidas, por conta de características das relações jurídicas existentes entre as partes.

Registra-se no ensejo, que tal possibilidade não é remota, basta que o réu tenha com os indivíduos beneficiados pela decisão, relação jurídica que lhe permita identificá-los, bem como identificar outras informações como: valores pagos e recebidos, o que é normal no atual cenário econômico e tecnológico, onde o atraso de poucos dias no pagamento de uma conta de luz, telefone, cartão de crédito ou qualquer outro produto consumido em massa, pode gerar a aplicação de inúmeras restrições.

Sendo assim, pode-se estabelecer a seguinte indagação secundária: sempre que o réu tiver a possibilidade de identificar, por conta própria, com suporte em sua base de dados, quem são os beneficiários da tutela coletiva e eventuais valores envolvidos, verse a sentença sobre obrigação de fazer, não fazer ou pagar quantia, deverá obedecer aos direitos individuais homogêneos reconhecidos, independentemente de liquidação e execução, a fim 
de se preservar o caráter molecular das demandas coletivas, conferindo-lhe mais efetividade?

Nesse instante, surge outro questionamento secundário: que interesse o réu teria em assim proceder, em contraste com a inércia típica dos condenados judiciais, que, via de regra, esperam as execuções para cumprir os provimentos?

A técnica visualizada por ora, como capaz de proporcionar o resultado ambicionado, qual seja: a satisfação voluntária dos direitos individuais homogêneos, reconhecidos em sentença coletiva condenatória, é o uso da tutela mandamental, que se traduz em ordens emanadas pela autoridade judicial, passíveis de coerção em caso de descumprimento.

É como se o juiz desse uma ordem, um mandamento, que pode e deve ser cumprido pela parte, independentemente de inciativas individualizadas, principalmente em casos envolvendo a coletividade.

Dessa maneira, prolatada uma sentença coletiva condenatória, envolvendo direitos individuais homogêneos, o juiz, dependendo das características dos fatos litigiosos - desde que o réu tenha condições de identificar os beneficiários da sentença e o eventual valor das prestações a serem realizadas, fixaria uma multa pelo descumprimento individual da decisão coletiva, a ser cobrada pelo individuo que não tiver o direito satisfeito em seu favor, em processo de liquidação e execução próprio, sendo indiferente a natureza da obrigação.

Deve-se ter em conta, que a presente proposta é diferente do que ocorre atualmente no cumprimento de sentença individual, aplicável à execução das sentenças coletivas, onde se tem uma multa aplicada pelo descumprimento de uma sentença já líquida.

Aqui, se está a cogitar da possibilidade de dispensa da liquidação, com um estímulo ao réu para que ele coopere, apurando os beneficiários da decisão e eventuais valores devidos, e adimplindo a respectiva obrigação, seja ela de fazer, não fazer ou pagar, consubstanciando-se esse estímulo em sanção pelo descumprimento da respectiva ordem judicial.

Outrossim, a proposta em questão não decorre naturalmente do artigo 461 do CPC, ainda quando as obrigações relacionadas aos direitos individuais homogêneos sejam de fazer ou não fazer, por não existir disposição expressa nem prática consolidada, que 
orientem pelo estabelecimento de multa automática pelo descumprimento individual de sentença coletiva.

Nos tópicos seguintes, serão discutidos os diversos aspectos envolvidos na técnica sugerida, relacionados: ao que se entende por tutela mandamental, à possibilidade jurídica do seu uso com esse propósito, à forma como se daria o seu manejo na sentença coletiva e eventuais execuções individuais, às particularidades que as diferenças na natureza das obrigações (de fazer, não fazer e pagar) podem apresentar, ao valor da multa, que deverá ser suficiente para estimular o réu, bem como à sua possibilidade de exclusão ou alteração em variadas hipótese e com diversificados propósitos, e à necessidade de observância do contraditório na sua fixação.

\subsubsection{A possibilidade de uso da tutela mandamental como meio de potencialização da efetividade da tutela coletiva de direitos individuais}

No contexto atual, de nova conformação estrutural e substancial da sociedade, que impõe um novo modelo de jurisdição e processo, voltado não mais para os casos individuais, mas sim e com igual ou maior importância para os casos envolvendo interesses coletivos lato sensu, os estudos devem se voltar aos mecanismos que possibilitem um aprimoramento da tutela jurisdicional realizada nesses conflitos de massa.

Como dito, nos casos de demandas coletivas envolvendo direitos individuais homogêneos, muitas vezes se padece com uma falta de efetividade, decorrente da necessidade de instauração de inúmeras liquidações e execuções individuais ${ }^{435}$ após a concessão da tutela coletiva, independentemente da natureza da obrigação, pois tradicionalmente os réus se mantêm inertes, mesmo após o transito em julgado da causa e mesmo em se tratando de obrigação de fazer ou não fazer ${ }^{436}$, esperando sempre pela

\footnotetext{
${ }^{435}$ Sergio Cruz ARENHART; Aluísio Gonçalves de Castro MENDES; Gustavo OSNA. "Cumprimento de sentenças coletivas: da pulverização à molecularização.” Revista de Processo,p. 60-61.

${ }^{436}$ Segundo o STJ, em julgamento proferido em sede de AgRg no AgRg no REsp 888328 / RS, de Relatoria do Min. Arnaldo Esteves Lima, 5a Turma, prolatado no dia 06 e publicado no dia 24/11/2008, ficou consignado que:1. "São devidos honorários advocatícios pela Fazenda Pública nas execuções individuais de sentença proferida em ações coletivas, ainda que não embargadas" (Súmula 345/STJ). 2. Em se tratando de execução de sentença que concede a servidores públicos reajuste salarial, é possível a cumulação de execução de pagar quantia certa (referente às parcelas vencidas) e de fazer (para incorporação do reajuste aos vencimentos)". (grifo nosso). Disponível em: www.stj.gov.br. Acesso em: 11 de jun. de 2012. Percebe-se daí, a necessidade de execução individual, mesmo em se tratando de obrigações de fazer envolvendo a Fazenda Pública.
} 
provocação do credor para dar início ao cumprimento da sentença, mormente em se tratando de sentença coletiva.

Nesses casos, deve-se pensar numa maneira de se reduzir a necessidade de tais procedimentos, de modo que o direito seja satisfeito independentemente deles, surgindo daí questão relativa à possibilidade de tanto.

Tradicionalmente, a liquidação e a execução são técnicas voltadas à quantificação do bem devido e à sua entrega, respectivamente.

No processo coletivo, contudo, a liquidação ganha maior amplitude, pois além de ser apurar o quantum debeatur, se deve apurar o cuidebeatur, ou seja, a quem é devido ${ }^{437}$, de modo que o autor deverá demonstrar a existência de relação jurídica entre ele e o condenado, o que poderá ser feito diretamente na execução individual, nas hipóteses de obrigação de fazer ou não fazer, que não comportam liquidação ${ }^{438}$.

A sentença coletiva será genérica, nos termos do artigo 95 do CDC, na medida em que apenas reconhecerá a obrigação, sem dizer a quem é devido e o quanto é devido nas obrigações de pagar, o que é consequência de razões diferentes da sentença genérica do processo individual.

A sentença genérica individual pressupõe a impossibilidade de quantificação do bem devido na fase de conhecimento do processo ${ }^{439}$.

Já a sentença coletiva será genérica pela dificuldade de se identificar todos os beneficiários no bojo da fase de conhecimento, bem como os valores das eventuais prestações devidas a cada um, se for o caso.

Uma atividade dessa magnitude, como ocorre no direito norte-americano ${ }^{440}$, aumentaria em demasia os custos e a demora da tutela coletiva, razão pela qual, no Brasil

\footnotetext{
${ }^{437}$ Luiz Rodrigues WAMBIER; Teresa Arruda Alvim WAMBIER. "Anotações sobre a liquidação e a execução das sentenças coletivas.”In: Ada Pelegrini GRINOVER; Aluisio Gonçalves de Castro MENDES; Kazuo WATANABE (Coord.). Direito processual coletivo e o anteprojeto de Código Brasileiro de Processos Coletivos,p. 273.

${ }^{438}$ Paulo Henrique dos Santos LUCON. In: Antonio Carlos MARCATO (Coord.). Código de Processo Civil interpretado, p. 1771. Candido Rangel DINAMARCO. Instituições de Direito Processual Civil, vol. IV, p. 215. Ambos os autores refutam a liquidação envolvendo obrigação de fazer ou não fazer, apesar de não convergirem sobre a necessidade de liquidação de obrigação de entregar coisa. $O$ primeiro entende desnecessária, já o segundo não.

${ }^{439}$ Cassio Scarpinella BUENO. In: Antonio Carlos MARCATO (Coord.). Código de Processo Civil interpretado, p. 884-885.

${ }^{440}$ Cassio Scarpinella BUENO. “As classactionsnorte-americanas e as ações coletivas brasileiras: pontos para uma reflexão conjunta.”Revista de Processo, p. 113-114.
} 
se transfere ao indivíduo credor essa faculdade, que provocará a máquina estatal por meio da demanda de liquidação individual.

A proposta em debate é para que o indivíduo continue realizando a liquidação e a execução do julgado coletivo, mas desta vez, é o indivíduo réu que deverá fazê-lo, e extrajudicialmente, pois em diversas demandas coletivas envolvendo direitos individuais homogêneos, o próprio réu tem meios de identificar os beneficiários de uma sentença condenatória coletiva, independentemente da natureza da obrigação, bem como aferir eventuais valores devidos a eles.

Em casos envolvendo o reajuste abusivo de mensalidades, por exemplo, onde uma sentença coletiva determine a aplicação de um índice de reajuste inferior, bem como a restituição daquilo que foi pago a mais, via de regra, o respectivo réu terá condições de identificar quais são seus clientes que terão uma redução no índice de reajuste, bem como quanto deverá ser devolvido a cada um, ainda que não haja liquidações e execuções individuais.

Naturalmente, essa atividade gerará um grande trabalho para o réu, entretanto, se não for assim, o grande trabalho será do indivíduo beneficiário, que dependerá de um processo de liquidação e execução, e do Estado-Jurisdição, que terá de apurar o nexo e concretizar o eventual direito existente.

Não se trata propriamente, de eliminar o trabalho de liquidação e execução, mas de transferi-lo ao réu, considerado sem razão no julgamento do mérito da demanda coletiva.

$\mathrm{Na}$ atual conjuntura, além de se concentrarem os litígios e as pretensões em demandas coletivas, para se responder às necessidades dos novos tempos, devem-se também distribuir atividades que seriam típicas do Judiciário aos particulares, sempre que possível.

Essa postura, contida, por exemplo, nas defesas de técnicas de execução extrajudiciais, retira do Estado a sobrecarga de atribuições que emergiram após a evolução dos modelos de Estado, distribuindo-a entre os particulares, na medida do possível, ou seja, naquilo em que os objetivos não restem desnaturados ou desrespeitados por tal ação.

A tutela mandamental surge nesse contexto, como única técnica processual apta a proporcionar resultados úteis em relação à proposta acima, pois do contrário, como se obrigaria o particular a realizar a atividade que, tradicionalmente, competia aos próprios 
beneficiários dela? Como obrigar o réu a proceder com uma conduta que lhe trará prejuízos?

A tutela mandamental, como bem ensinado por Barbosa Moreira em fantástico estudo sobre o tema, tem suas origens na doutrina Alemã, capitaneada por Kutner, que originariamente, assim classificava as sentenças nas quais se emitia uma ordem endereçada a outro órgão do Estado, que não havia sido parte no processo ${ }^{441}$.

O objetivo do professor tedescoera, ao que dá conta Barbosa Moreira, o de investigar a vinculação à coisa julgada por parte dos órgãos públicos que, mesmo não tendo sido partes no processo, eram obrigados a atender os comandos jurisdicionais necessários à satisfação do provimento ${ }^{442}$.

Para a doutrina alemã, portanto, a decisão que determina o registro de uma sentença de usucapião, por exemplo, no cartório de registro de imóveis, seria mandamental, na medida em que impõe uma ordem a outro órgão público, terceiro no processo ${ }^{443}$.

Nada obstante, no Brasil a tutela mandamental foi pioneiramente estudada por FRANCISCO DE CAVALCANTI PONTES DE MIRANDA, que lhe atribuiu significado bem diferente, aproveitando apenas a ideia de ordem, da noção alemã original ${ }^{444}$.

Segundo o referido autor, a sentença mandamental caracterizava-se pela emissão de uma ordem a uma pessoa, que poderia ser um particular, que como parte no processo deveria atender ao que o juiz manda ${ }^{445}$.

Esse conceito predominou na doutrina pátria e sua inclusão dentre as espécies de sentenças ou tutelas existentes deu ensejo à concepção da teoria quinaria, contraposta à ternária, apesar dos desvios científicos proporcionados por essa inclusão, que mistura na classificação das sentenças o critério tradicional, baseado no efeito do provimento judicial em relação ao direito material, com o critério baseado nas técnicas usadas para a obtenção dos efeitos previstos na sentença ${ }^{446}$.

\footnotetext{
${ }^{441}$ José Carlos BARBOSA MOREIRA. "A sentença mandamental da Alemanha ao Brasil."Revista de Processo,p. 02.

${ }^{442}$ Ibid., p. 02

${ }^{443}$ Ibid., p. 03

${ }^{444}$ Ibid., p. 03

${ }^{445}$ Francisco Cavalcanti PONTES DE MIRANDA. Tratado das Ações. t. VI, p. 3.

${ }^{446}$ José Roberto dos Santos BEDAQUE. Efetividade do processo e técnica processual,p. 519-520, afirma que: "[...] a classificação quinaria, além de não contribuir para o aperfeiçoamento cientifico do direito
} 
Sendo assim, a tutela mandamental hoje é entendida como a proteção consubstanciada numa ordem endereçada à parte, para que esta proceda como manda a decisão judicial, sob pena de não o fazendo, ter de suportar as respectivas sanções ${ }^{447}$.

Percebe-se assim, a utilidade da tutela mandamental para a proposta ora desenvolvida, já que, por meio dela, o juiz determinará que o próprio réu liquide a sentença coletiva, quando tal providencia estiver ao seu alcance, identificando os seus beneficiários e eventuais quantias devidas a eles, realizando, em ato conseguinte, a satisfação dos direitos identificados, independentemente de pedidos individuais.

Assim sendo, o réu condenado por uma sentença coletiva, que tutele direitos individuais homogêneos, terá de proceder à liquidação e satisfação voluntárias dos respectivos direitos, sempre que isto for possível a ele, sob pena de sofrer a incidência de sanções tendentes a sua coação, como por exemplo, multas individuais, que deverão ser suficientes, como se discutirá ao final, para estimular o réu em tal ação.

Tratando-se de obrigação de fazer ou não fazer relativa a direito individual homogêneo, que dispensam a liquidação, caberá ao réu satisfazer os direito reconhecidos em juízo, independentemente de execuções individuais com este objeto, sob pena de pagar multas individuais pelo descumprimento, ou seja, por cada execução individual que sua omissão dê ensejo.

Tratando-se de obrigação de pagar quantia relativa a direito individual homogêneo, caberá ao réu satisfazer os direitos reconhecidos em juízo, antes que sejam instauradas as respectivas liquidações e execuções, sob pena de também incorrer em multas por cada execução individual ajuizada justamente.

Face a esse panorama, surgem questões relevante, relacionadas à possibilidade do uso da tutela mandamental visando à satisfação de obrigações de pagar quantia, e a forma do seu uso em relação às obrigações de fazer e não fazer, que mesmo possuindo

processual, também do ponto de vista prático não apresenta grande utilidade. Ao contrário, é teoricamente criticável, visto que fundada em critérios heterogêneos".

${ }^{447}$ LUCON, op. cit. p. 1870-1871, nota 438. Nesse sentido, se afirma que: "Em alguns casos, pode ser conferido ao título que se executa caráter mandamental, com a imposição de medidas coercitivas e de apoio exemplificadamente relacionadas no art. 461". E ainda: "A multa confere um atributo de mandamentalidade à sentença que impõe o cumprimento de uma obrigação especifica”. BUENO, op. cit. p. 1406, nota 439, vai mais direto ao ponto, afirmando que: "Por tutela (ou sentença) mandamental deve-se entender a técnica que pretende extrair do devedor o cumprimento voluntário (não espontâneo, que significaria prescindir da intervenção jurisdicional) da obrigação, isto é, que pretende que o próprio obrigado, por ato seu, cumpra a obrigação, tal qual lhe foi imposta pela lei ou ajustada, por contrato, entre as partes". 
autorização expressa contida no artigo 461 do CPC, deixa dúvidas sobre o seu manejo adequado, especialmente no campo da tutela coletiva.

\subsubsection{O seu uso nos casos envolvendo obrigações de fazer e não fazer}

Como visto no tópico acima, a tutela mandamental tem a aptidão de proporcionar maior efetividade aos provimentos jurisdicionais, na medida em que lhes outorga a forma de uma ordem judicial, que, se descumprida, resultará na utilização de meios coercitivos, a fim de coagir o réu a cumprir voluntariamente a obrigação, dispensando-se, com isto, o uso de meios sub-rogatórios.

Nem sempre a tutela mandamental se mostrará a mais adequada, pois há casos em que os meios sub-rogatórios se mostram dotados de eficácia suficiente e satisfatória.

No caso das obrigações de fazer e não fazer a tutela mandamental atualmente é imprescindível, ganhando cada vez mais espaço conforme a importância dada à satisfação in natura dessas obrigações.

A cultura liberal que emergiu no século XVIII estabeleceu como paradigma jurídico no âmbito civil, a impossibilidade de se constranger alguém a fazer algo diferente de sua vontade, o que desaguava na necessidade de conversão das obrigações de fazer ou não fazer inadimplidas, em perdas e danos, prosseguindo a execução como de pagamento de quantia ${ }^{448}$.

Tudo basicamente se resolvia em perdas e danos, o valor universal do dinheiro era tido como a solução única para os problemas de inadimplemento obrigacional, independentemente da natureza da obrigação, uma vez que não se admitia a coerção de individuo algum ao cumprimento de uma ação.

Admitia-se a invasão no seu patrimônio, por meio sub-rogatórios, mas não na sua esfera de liberdade, com a coação ao cumprimento de um fazer ou não fazer.

\footnotetext{
${ }^{448}$ José Manuel ARRUDA ALVIM NETTO. “Obrigações de fazer e não fazer - direito material e processo."Revista de Processo, p. 5. Nesse sentido, o autor ensina que: "Isto porque, conquanto o não adimplemento de uma obrigação de fazer ou de não fazer fosse um ilícito, não é menos certo que o Direito não proporcionava - e não os tinha porque a ideia de liberdade não admitia tais meios - instrumentos, como os hoje enseja francamente preordenados para coagir o inadimplente, ao adimplemento, senão que, a única solução conhecida e aceita era a tutela ressarcitória, depois do processo de conhecimento".
} 
O uso de técnicas coercitivas era tido como incompatível com o direito humano à liberdade, que a cultura iluminista, concebida principalmente na França, prestigiava com preponderância; não à toa, o Código Civil francês prescreve que o descumprimento de obrigação de fazer ou não fazer resolve-se em perdas e danos ${ }^{449}$, o que consta no Código Civil brasileiro até hoje, para os casos de obrigações de fazer infungíveis, sem que possa ser reduzido à ideia de vedação ao uso de meio coercitivos.

Aliás, segundo JOSÉ MANUEL ARRUDA ALVIM NETTO, na própria França se desenvolveu o antídoto contra esse posicionamento extremadamente liberal, quando a jurisprudência passou a aceitar o uso das astreintes, primeiro com fins reparatórios, ficando limitada ao valor da obrigação, mas num segundo momento, com o fim de coerção e estímulo ao cumprimento de obrigações de fazer ou não fazer reconhecidas em decisões judiciais $^{450}$.

De igual modo, as últimas reformas legislativas brasileiras no âmbito processual convergiram pela autorização expressa, do uso de meios coercitivos como meio de execução apto não só a satisfação de obrigações de fazer e não fazer, como de entregar coisa, merecendo destaque especial a LACP, pioneira nessa técnica com seu artigo 11, e posteriormente o Código de Defesa do Consumidor, em seu artigo 84, ambos inspiradores dos posteriores artigos $461^{451}$.

Essa mudança foi resultado da crise de efetividade padecida por essas espécies de obrigação, mormente as de fazer e não fazer, o que impôs reflexão e mudanças nos mecanismos de realização de tais direitos.

Engraçado lembrar, que desde o Código de 1939 havia previsão da ação cominatória, ignorada no Código de 1973, de modo a ensejar o ajuizamento de ações declaratórias (para que se reconhecesse a existência e o conteúdo da obrigação), seguidas de ações cautelares inominadas (para liminarmente se obter uma ordem de abstenção) ${ }^{452}$.

\footnotetext{
${ }^{449}$ Ibid., p. 7.

${ }^{450}$ Ibid., p. 7. Afirma o autor que: "No direito francês, que sabidamente foi asede desse entendimento de as perdas e danos solucionarem os inadimplementos em relação às obrigações de fazer e de não fazer, aí nasceram por pura construção pretoriana as astreintes".

${ }^{451}$ Ada Pelegrini GRINOVER. "Tutela jurisdicional nas obrigações de fazer e não fazer."Revista de Processo, p. 3 .

${ }^{452}$ José Carlos BARBOSA MOREIRA. "A tutela especifica do credor nas obrigações negativa.”In: Temas de Direito Processual, p. 41.
} 
Nessa esteira, hoje não restam dúvidas sobre a consolidação do uso de meios coercitivos a fim de se constranger o devedor ao cumprimento de uma obrigação de fazer ou não fazer, numa senda contraposta a que prevaleceu durante muitos anos e frustrou a expectativa de muitas pessoas na obtenção da tutela especifica, ou seja, de tutela idêntica ao que se teria com o cumprimento espontâneo de obrigação envolvendo bem especifico $^{453}$.

Destarte, em sede individual, proferida decisão que reconheça direito ao cumprimento de uma obrigação de fazer ou não fazer, a própria decisão deve prever uma multa ou outra medida executiva para o caso de descumprimento, de modo que se estimule o cumprimento voluntário da decisão, ou, na pior das hipóteses, se garanta um resultado prático equivalente.

Ainda que o meio executivo não tenha sido previsto na própria decisão a ser executada, nada impede a sua adição posterior $^{454}$.

Já em âmbito coletivo, a sentença que reconhece direito ao cumprimento de uma obrigação de fazer ou não fazer envolvendo direitos individuais homogêneos poderá seguir duas receitas, havendo uma que encontra maior convergência com o caráter molecular do processo coletivo e, por isto, encontra apoio neste ensaio.

Uma primeira forma seria a simples prolação da decisão condenatória em sentido $\operatorname{amplo}^{455}$, que em seguida seria objeto de inúmeras execuções individuais, onde o réu seria citado para cumprir a obrigação de fazer ou não fazer em determinado prazo, sob pena de multa.

Outra forma, mais condizente com o caráter molecular da tutela coletiva, seria a decisão coletiva ordenar o cumprimento de obrigação de fazer ou não fazer relativa à direito individual homogêneo, já estabelecendo uma multa individual para o caso de descumprimento voluntário, com o fito de se eliminar, ou ao menos reduzir, a necessidade de ajuizamento de milhares de execuções individuais, quando possível ao réu identificar os beneficiários da decisão coletiva.

\footnotetext{
${ }^{453}$ Teori Albino ZAVASCKI. “Antecipação de tutela e obrigações de fazer e de não fazer.”Revista Jurídica,p. 20.

${ }^{454}$ José Carlos BARBOSA MOREIRA. “A sentença mandamental da Alemanha ao Brasil.”Revista de Processo,p. 6.

${ }^{455}$ José Roberto dos Santos BEDAQUE. Efetividade do processo e técnica processual,p. 535. Para o autor, a tutela mandamental e a executiva estão relacionadas com a condenatória.
} 
Dessa maneira, a sentença coletiva apenas dirá o que deverá ser feito ou não, estabelecendo um prazo para tanto e ordenando que assim se proceda, sob pena do réu ter de adimplir multas individuais, caso execuções individuais sejam instauradas.

Como dito alhures, essa técnica pressupõe que o réu tenha formas de identificar os beneficiários da decisão e, portanto, cumpri-la voluntariamente.

Sempre que essa identificação se mostrar impossível ou muito difícil, será incabível e desproporcional impor um ônus excessivo ao réu, mostrando-se a medida inadequada ao alcance dos fins pretendidos ${ }^{456}$, que não são o de prejudicar nenhuma parte, mas apenas acelerar e simplificar a atividade jurisdicional.

Além disso, sempre que a identificação tiver sido realizada, mas o cumprimento voluntário tiver sido comprovadamente obstado pelo individuo, não se mostrará adequada a aplicação de qualquer sanção, tendo em vista a mora do credor.

Sem embargo, toda vez que houver uma execução individual visando à satisfação de ordem relativa à obrigação de fazer ou não fazer, caberá ao réu adimpli-la com a multa pelo descumprimento individual da respectiva obrigação, ressalvada a hipótese de se provar a colocação de óbices, propositais ou não, pelo próprio credor.

Buscando-se exemplificar o que se está a falar, pode-se trabalhar com o seguinte caso: imagine que o Judiciário tenha proferido decisão que impõe ao réu, Fazenda Pública com milhares de servidores, a observância de determinado patamar de reajuste, a ser incluído mensal e continuamente na remuneração de diversos servidores ${ }^{457}$.

\footnotetext{
${ }^{456}$ Marcelo José Magalhães BONICIO. Proporcionalidade e processo: a garantia constitucional da proporcionalidade, a legitimação do processo civil e o controle das decisóes judiciais, p. 27-28. O autor trabalha com os subprincípios da proporcionalidade, dentre eles o da adequação, que impõe o uso de meios aptos à consecução do objetivo almejado. Os outros subprincípios são da necessidade e proporcionalidade em sentido estrido. No presente ensaio, percebe-se que é inadequado, por não proporcionar o objetivo ansiado, determinar que o réu faça algo impossível ou extremamente difícil. Robert ALEXY. Teoria dos direitos fundamentais,p. 116-117. ROBERT ALEXY fala da imprescindibilidade do manuseio da proporcionalidade quando da aplicação de princípios, pelas colisões advindas de tal aplicação, como consequência da estrutura aberta dessas normas.

${ }^{457}$ Segundo o STJ, em julgamento proferido em sede de AgRg no AgRg no REsp 888328 / RS, de Relatoria do Min. Arnaldo Esteves Lima, 5a Turma, prolatado no dia 06 e publicado no dia 24/11/2008, ficou consignado que:1. "São devidos honorários advocatícios pela Fazenda Pública nas execuções individuais de sentença proferida em ações coletivas, ainda que não embargadas" (Súmula 345/STJ). 2. Em se tratando de execução de sentença que concede a servidores públicos reajuste salarial, é possível a cumulação de execução de pagar quantia certa (referente às parcelas vencidas) e de fazer (para incorporação do reajuste aos vencimentos)". (grifo nosso). Disponível em: www.stj.gov.br. Acesso em: 11 de jun. de 2012. Percebe-se daí, a necessidade de execução individual, mesmo em se tratando de obrigações de fazer envolvendo a Fazenda Pública.
} 
Essa decisão, para que se prestigie o caráter molecular da tutela coletiva, deverá prever em seu bojo medida executiva que estimule o seu cumprimento voluntário, dispensando-se execuções individuais, ainda que se trate da Fazenda Pública, pois esta tem plenos meios de identificar os beneficiários da decisão e os valores que farão parte das novas remunerações.

Dessa maneira, a ré deverá automaticamente, após o inicio da eficácia da decisão, cumpri-la e passar a adimplir voluntariamente o reajuste devido a todos os servidores beneficiários da decisão, sob pena de pagar multa individual por cada inadimplemento e execução individual que der causa.

Havendo recusa, não haverá jeito, caberá ao individuo vir a juízo e executar a sentença coletiva a fim de obter o fazer que lhe é devido, mais a multa pelo descumprimento da obrigação, podendo o réu, em sede de impugnação, defender-se alegando, por exemplo, a não ocorrência da recusa e sim a mora do credor.

Não obstante, grandes chances haverá de o réu cumprir voluntariamente a obrigação, principalmente se a multa tiver sido fixada em valor compatível com esse propósito, e no caso da Fazenda Pública, houver meios de também se coagir os agentes responsáveis pelo fazer devido, o que será assunto para outros estudos.

Em exemplo envolvendo obrigações de não fazer, pode-se pensar naquelas hipóteses envolvendo reajuste abusivo de valores decorrentes de seguros de saúde.

Havendo uma ordem que imponha a não cobrança de reajuste abusivo de clientes de uma determinada operadora, esta deverá cumprir de imediato a decisão, independentemente do ajuizamento de execuções individuais, fixando-se multa individual pelo descumprimento.

Diante de qualquer execução individual na qual se pretenda o cumprimento da obrigação de não fazer descumprida, ou seja, que seja extirpada a cobrança ilegal do reajuste, deverá ser realizada não só a tutela específica, como também deverá ser adimplida a multa decorrente do não cumprimento voluntário, que resultou na execução individual.

Nesse cenário, a tutela mandamental ganha contornos similares aos das inujunctions americanas, amplamente utilizadas nos processos coletivos envolvendo direitos difusos ou coletivos stricto sensu, para a realização de reformas estruturais em 
grandes instituições públicas como escolas, presídios e hospícios, dotadas de burocracias incompatíveis com os valores constitucionais modernos ${ }^{458}$.

Nada obstante, no caso em tela as grandes estruturas a serem reformadas não se restringem à esfera pública, estando abarcadas as grandes corporações privadas, que usam e abusam do poder econômico e mantém relações jurídicas com milhares de pessoas lesadas pelo seu comportamento ilegal, estabelecendo teias no seio da sociedade, muito mais sólidas e influentes que diversos entes estatais.

Outrossim, os direitos tutelados pela proposta em análise são divisíveis e, portanto, individualizáveis, características que, contudo, não retiram o grande aspecto reformador e transformador da tutela coletiva em questão, que intervirá na seara privada ou pública, a fim de fazer cessar ilegalidade por ação ou omissão, estabelecida de maneira estrutural de modo a atingir a coletividade.

Conclui-se assim, ser de extrema importância a dotação da tutela coletiva envolvendo obrigações de fazer ou não fazer relativa à direitos individuais homogêneos, de técnica mandamental, a ponto de justificar o desenvolvimento de meios, convergentes com o ordenamento pátrio, de aprimoramento dessa tutela, que autorizem a fixação de multas individuais no título executivo coletivo, com o escopo de se evitar a necessidade de execuções individuais, quando possível ao réu.

\subsubsection{O seu uso nos casos envolvendo obrigação de pagar quantia}

No que tange às obrigações de pagar quantia, que tradicionalmente não admitiam o uso da tutela mandamental, ressalvados os alimentos novos decorrentes de relação de paternidade, o exame merece maiores cuidados.

Sobre o uso da tutela mandamental nas hipóteses de pagamento de quantia, FLÁVIO LUIZ YARSHELL já se posicionou contrariamente em estudo anterior, no qual

\footnotetext{
${ }^{458}$ Owen FISS. Um novo processo civil: estudos norte-americanos sobre Jurisdição, Constituição e sociedade, p. 27. Para o autor: "A reforma estrutural é baseada na noção de que a qualidade de nossa vida social é afetada de forma significativa pela operação de organizações de grande porte e não somente por indivíduos, agindo dentro ou fora dessas organizações. É também baseada na crença de que os valores constitucionais norte-americanos não podem ser totalmente assegurados, sem que mudanças básicas sejam efetuadas nas estruturas dessas organizações. O processo judicial de caráter estrutural é aquele no qual um juiz, enfrentando uma burocracia estatal no que tange aos valores de âmbito constitucional, incumbe-se de reestruturar a organização para eliminar a ameaça imposta a tais valores pelos arranjos institucionais existentes. Essa injunction é o meio pelo qual essas diretivas de reconstrução são transmitidas".
} 
identificou como desnecessário o uso de medidas coercitivas para obtenção de prestações de pagar quantia, ressalvadas as hipóteses previstas em lei, com as mitigações trazidas pela jurisprudência, ou ainda, a possibilidade de qualificação da obrigação como de fazer ${ }^{459}$.

Segundo o autor, que assim se manifestou anteriormente a criação do artigo 475-J do CPC, o ordenamento brasileiro nesses casos, apenas autorizaria o uso de técnicas subrogatórias, com a expropriação do patrimônio do devedor e a entrega do bem ou da quantia ao credor, sendo, portanto, desnecessária a fixação de multas, que poderiam acarretar numa violação ao principio da proporcionalidade ${ }^{460}$.

A tutela mandamental só seria realmente necessária, quando apta a impor ao réu conduta que facilite a satisfação do crédito pretendido, como, por exemplo, para se evitar atos atentatórios à dignidade da justiça ${ }^{461}$.

Esse posicionamento respalda o uso da tutela mandamental em sede coletiva, para coagir o réu a liquidar a sentença genérica por conta própria, quando isto for possível, bem como a satisfazer obrigações de fazer ou não fazer sem que haja execuções individuais, o que é parte da proposta ora encampada, mas não respaldaria o uso dessa técnica para constranger o réu a satisfazer obrigações de pagar quantia.

De fato, o uso da tutela mandamental no que tange a obrigações de pagar quantia, anteriormente à edição do artigo 475-J do CPC, era excepcional, já que a natureza da obrigação permite a sua satisfação pelo uso exclusivo da técnica sub-rogatória, sem a necessidade de meios coercitivos.

Não se admitia o seu uso ordinário apenas sob o pretexto de acelerar o processo individual; se havia patrimônio em nome do devedor, que fosse expropriado e adimplida a obrigação.

Nada obstante, em se tratando de processo coletivo envolvendo direitos individuais homogêneos, concernentes à obrigação de pagar quantia, a tutela mandamental se mostra necessária, não para acelerar o resultado de um único processo, mas sim com o escopo de dispensar inúmeras execuções individuais e manter íntegro o caráter coletivo, molecular da

\footnotetext{
${ }^{459}$ Flavio Luiz YARSHELL. "Tutela mandamental nas obrigações de pagamento de quantia."Revista da Procuradoria Geral do Estado de São Paulo, p. 274-275.

${ }^{460}$ Marcelo José Magalhães BONICIO. Proporcionalidade e processo: a garantia constitucional da proporcionalidade, a legitimação do processo civil e o controle das decisões judiciais, p. 27-28. Ainda que apta ao alcance de um fim, uma medida pode ser considerada desproporcional por ser desnecessária, ou seja, por haver outro meio de se conseguir o mesmo resultado com menor sacrifício a outros valores envolvidos.

${ }^{461}$ YARSHELL, op. cit. p. 277-278, nota 459.
} 
proteção oferecida, atendendo ao anseio por maior efetividade que acompanha esse tipo de processo $^{462}$.

Nas demandas coletivas, apesar da viabilidade dos meios sub-rogatórios para a satisfação de obrigações de pagar quantia, esses traduzem grande decréscimo de eficácia à tutela jurisdicional, por não reduzirem a necessidade de demandas individuais.

O uso da técnica mandamental no caso em tela, portanto, se justifica por razões diferentes de uma eventual proposta para a sede individual, qual seja: pela necessidade de preservação do caráter molecular da tutela coletiva, inexistente na tutela individual, mas que deve ser preservado sempre que possível, ainda que isto imponha o uso de forma não prevista em lei.

Aliás, essa postura é albergada pelo princípio da adequação, que influi no processo coletivo, impondo que a técnica processual pertinente seja adequada para proporcionar os resultados esperados ${ }^{463}$, e pelo direito fundamental de acesso à justiça ${ }^{464}$, plena e imediatamente aplicável, para proporcionar o acesso à ordem jurídica justa.

A ausência de previsão legal específica não pode servir de argumento, pois ainda que inexista forma específica para o uso de uma técnica, essa omissão não poderia traduzir-se em desrespeito ao direito fundamental de acesso à justiça, já que este não impõe a simples possibilidade de qualquer acesso, mas sim o melhor acesso possível ${ }^{465}$, sendo certo ainda, que nos casos de lacuna na lei devem ser aplicadas a analogia, os costumes e os princípios gerais do direito, ainda que se trate de omissão na lei processual, como dispõem o CPC e a LICC (Lei de Introdução ao Código Civil), em seus artigos 126 e $4^{\circ}$ respectivamente.

\footnotetext{
${ }^{462}$ Candido Rangel DINAMARCO. A instrumentalidade do processo, p. 397. O autor considera que a disciplina da legitimatio ad causamestreita a via de acesso à justiça, ignorando um ambiente solidarista, em que se poderia ter maior molecularização na atividade de resolução de conflitos.

${ }^{463}$ FredieDIDIER JÚNIOR; Hermes ZANETI JÚNIOR. "Principio da adequação jurisdicional do processo coletivo - benfazeja proposta contida no projeto da nova lei de ação civil pública."In: Petronio CALMON et al (Coord.). Em defesa de um novo sistema de processos coletivos: estudos em homenagem a Ada Pelegrini Grinover, p. 248. No mesmo sentido, mas com o foco voltado para os processos individuais: José Roberto dos Santos BEDAQUE. Efetividade do processo e técnica processual,p. 62-63. DINAMARCO, op. cit. p. 416, nota 462.

${ }^{464}$ Luciano Picoli GAGNO. Direito fundamental de acesso à justiça e técnicas de otimização da atividade e do juízo probatórios, p. 39. No trabalho, é desenvolvida a ideia de que o juiz é livre para adotar formas não previstas em lei, com o fim de aprimorar a efetividade processual, desde que respeitado o modelo constitucional de processo. Esse poder do Judiciário decorreria do direito fundamental de acesso à justiça, e estaria limitado pelos demais direitos fundamentais que gravitam no sistema constitucional.
}

${ }^{465}$ Ibid., p. 39. 
Além do mais, tudo que vem sendo dito conflui perfeitamente com o atual paradigma de cooperação no processo judicial, segundo o qual todos os seus atores devem agir de maneira a colaborar com a atividade judicial.

Se o réu tem em suas mãos todas as informações e meios necessários à satisfação de obrigações previstas em sentenças coletivas, deverá disponibilizá-los a fim de que os objetivos jurisdicionais não se vejam dificultado pela inércia da parte, nem o Estado seja onerado com o ajuizamento de milhares de demandas.

Somente assim, também o direito à razoável duração do processo poderá ser atendido em maior medida, como impõem os direitos fundamentais ${ }^{466}$.

Outra questão a se saber, é se o artigo 475-J do CPC já não autorizaria o que vem sendo falado, ao prever a aplicação de multa pelo inadimplemento de condenação ao pagamento de quantia líquida transitada em julgado.

Nesse cenário, deve-se esclarecer que em âmbito coletivo, a aplicação do artigo 475-J se daria somente após a liquidação individual, tendo em vista a iliquidez da sentença coletiva que condena ao pagamento de quantia, o que é diferente da técnica examinada neste trabalho, de coerção prévia à liquidação individual da sentença coletiva, a fim de se evitar a fragmentação dessa tutela, sempre que possível ao réu saber o que seria revelado na liquidação.

Registra-se, portanto, que a técnica insculpida no artigo 475-J do CPC e que autoriza a imposição de multa pelo não adimplemento de obrigação de pagar quantia, não se confunde nem prejudica a presente proposta, muito pelo contrário, demonstra a sua pertinência contextual, na medida em que também confia à tutela mandamental o anseio por maior efetividade.

A diferença é que, na esfera individual se pretende acelerar evitando-se a fase de execução, enquanto na esfera coletiva, o que se propõe é acelerar evitando-se a liquidação e a execução individuais, muito mais nocivas para a demanda coletiva, que a simples necessidade de fase executiva para a demanda individual.

Destarte, a coerção em discussão deverá ser operada por ordem contida na sentença coletiva, anteriormente a liquidação individual.

\footnotetext{
${ }^{466}$ Robert ALEXY. Teoria dos direitos fundamentais, p. 90. Segundo o autor tedesco, os direitos fundamentais, normas com estrutura principiológica, configurariam mandamentos de otimização, que impõem a feitura de algo na maior medida das possibilidades fáticas e jurídicas.
} 
Deve-se distinguir as técnicas, portanto, pelos matizes nos seus propósitos e dimensões, que redundam em diferentes modos de aplicação; a multa prevista no artigo 475-J pretende reduzir a necessidade de longas e frustrantes fases executivas, incidindo sobre condenações de pagar quantias líquidas; já a técnica coercitiva em debate, pretende reduzir o número de liquidações e execuções individuais de sentença coletiva, incidindo sobre condenações de pagar quantias liquidáveis pelo réu.

Se o réu não liquidar e satisfizer tempestivamente obrigação de pagar quantia, relativa à direito individual homogêneo reconhecido em sentença coletiva, quando possível a realização dessa atividade por ele, a partir de então incidirá multa pelo descumprimento de ordem continente de tal incumbência, e não da intimação para pagar quantia líquida, como ocorre no artigo 475-J do CPC. ${ }^{467}$

Incidindo a multa pela omissão do réu, o beneficiário poderá exigi-la, em liquidação e execução individual, juntamente com a obrigação principal, devendo-se discutir, em tópico próprio, os limites para tanto.

Nessa altura, poderia se perguntar se tudo não acabaria dando no mesmo, com milhares de liquidações e execuções individuais, onde se exigiria além da prestação principal a multa.

Em verdade, o proveito a ser extraído dessa proposta, assim como no caso da medida executiva contida no artigo 475-J do CPC, dependerá da vontade do réu, que é livre para bem dispor do seu patrimônio, como sempre ocorre com o uso da técnica mandamental, que pressupõe a vontade do réu no cumprimento da obrigação, estimulada por meios coercitivos (indiretos) de execução.

Se ele quiser optar pelo oferecimento de resistência à efetividade da tutela jurisdicional, não só o Estado-Jurisdição arcará com esse custo, como tradicionalmente ocorre, mas também o réu, adimplindo multas suficientemente relevantes e estimulantes ao cumprimento voluntário da obrigação.

Caso o réu opte pela economia de milhares ou milhões de reais em multas, milhares ou milhões de liquidações e execuções individuais também serão economizadas, gerando

\footnotetext{
${ }^{467}$ O STJ já pacificou o entendimento de que o prazo para pagamento de quantia prevista em sentença transita em julgado, conta-se da intimação do seu advogado. Conferir o resultado do recurso de Agravo Regimental no Recurso Especial ${ }^{\circ}$ 1264045/RS, da lavra do Min. Mauro Campbell Marques, Segunda Turma, julgado em 11/10/2012, publicado em 18/10/2011. Disponível em: www.stj.gov.br. Acesso em: 12 de jun. de 2012.
} 
ganho de tempo e recursos para todos, principalmente para o individuo que teve o direito lesado.

Deve-se descortinar no ensejo, o propósito de um novo modo de pensar embutido na técnica em exame, que retira do Estado o dever de realização de determinadas prestações, transferindo-as ao particular, juntamente com sanções pelo seu descumprimento, a fim de que se ganhe em liberdade, com a menor necessidade de intervenção estatal na esfera privada e uma consequente maior responsabilização pelo mau uso dessa liberdade.

Pode-se exemplificar a proposta em análise com o seguinte caso: sentença coletiva condenou o réu, empresa de telefonia, a restituir valores cobrados indevidamente dos seus clientes durante determinado período.

Na própria sentença genérica será reconhecida a facilidade com que a empresa ré pode identificar os beneficiários da decisão e os valores que serão devidos a cada, ordenando-se que ela assim proceda, satisfazendo voluntariamente os direitos individuais homogêneos identificados, em prazo razoável, sob pena multa pelo descumprimento individual.

Descumprida a obrigação, surgirá a execução individual na qual serão exigidas a obrigação principal e a multa.

Percebe-se assim, que apesar de não possuir previsão legal, a proposta em questão também não é vedada, sendo, muito pelo contrário, conforme o sistema jurídico pátrio, analisado tanto na ótica constitucional do direito fundamental de acesso à justiça, como na ótica infraconstitucional, não havendo que se falar em violação a qualquer regra ou princípio concernente ao devido processo constitucional ${ }^{468}$.

No tópico seguinte, serão discutidos aspectos relacionados a essa multa, principalmente no que tange a observância do contraditório, condição essencial para que a técnica em estudo funcione sem excessos ou distorções.

\footnotetext{
${ }^{468}$ José Roberto dos Santos BEDAQUE. Efetividade do processo e técnica processual,p. 26 . O autor decifra o devido processo constitucional como um processo justo, onde a observância das formas seja um simples meio de se garantir os valores constitucionais. Segundo ele: "A técnica processual, em última análise, destina-se a assegurar o justo processo, ou seja, aquele desenhado pelo legislador ao estabelecer o modelo constitucional ou o devido processo constitucional".
} 


\subsubsection{O contraditório na fixação da multa e a possibilidade de exclusão ou modificação do seu valor}

O princípio do contraditório é ponto fundamental para uma análise de técnicas processuais aptas ao aprimoramento da tutela jurisdicional, pela necessidade de sua confluência com os preceitos constitucionais que estruturam o modelo de processo justo ${ }^{469}$.

Nesse contexto, pensada a utilização da tutela mandamental no bojo de uma decisão coletiva nos moldes ora discutidos, seja ela antecipatória ou definitiva, mostra-se necessário o contraditório prévio, mesmo porque, em demandas coletivas não fica caracterizada nenhuma situação particular de dano iminente; caso o particular padeça de tal emergência, o mais adequado a ele será a demanda individual ou ao menos a execução individualizada.

Assim sendo, a principal razão para o prestígio ao contraditório prévio à utilização da tutela mandamental proposta, concerne à necessidade de debate, sobre o fato de o réu ter ou não condições de identificar os beneficiários da decisão coletiva e eventuais valores a serem pagos; é importante que a ré tenha condições de influir nesse exame, pois essa é a ideia moderna de contraditório ${ }^{470}$.

Poderá o réu discutir o fato de haver ou não em seu poder, documentos suficientes que permitam a liquidação e a satisfação dos direitos individuais homogêneos por conta própria, admitindo-se, inclusive, instrução probatória neste sentido, em consonância com a garantia de ampla defesa ${ }^{471}$.

Isso não significa que a tutela mandamental só possa ser utilizada na sentença, mas apenas, que é necessário o respeito ao contraditório prévio a utilização de tal técnica, por ser necessário a uma decisão mais justa, e ser desproporcional a supressão desse direito, seja pela falta de adequação, seja pela falta de necessidade.

\footnotetext{
${ }^{469}$ Luigi Paolo COMOGLIO. Eticae tecnicadel “giusto processo”, p. 54. O autor trabalha com um núcleo mínimo de garantias relativas a um processo justo, tais como: direito de ação, de defesa, e a um juiz imparcial.

${ }^{470}$ Nicola PICARDI. Jurisdição e Processo,p. 142-143. Para o autor, o contraditório é fundamental para a qualificação da decisão.

${ }^{471}$ BEDAQUE, op. cit. p. 484-485, nota 468. O autor entende a ampla defesa como um consectário de um contraditório efetivo. Nas suas palavras: “Representam as duas expressões - 'defesa' e 'contraditório' visões diversas da mesma realidade, consistente em garantir às partes a possibilidade de real participação no desenvolvimento do processo, objetivando a tutela de seus interesses".
} 
Portanto, nada obsta que eventual omissão na decisão antecipatória ou na sentença, a respeito do uso de meios coercitivos com o fim de se evitar liquidações e execuções individuais, seja sanada em decisão posterior, de oficio e mesmo após o trânsito em julgado, de modo coerente com a sistemática do artigo 461 do CPC.

Por se tratar de matéria exclusivamente processual, de interesse público e divorciada do mérito da causa, a utilização de meios executivos coercitivos para se obter a efetivação de decisão judicial não encontra óbice em institutos como o da preclusão ou coisa julgada, tanto que o próprio legislador foi claro ao autorizar modificações no valor e na periodicidade da multa ${ }^{472}$.

Da mesma forma ocorre com os meios sub-rogatórios, tendo-se a penhora como exemplo; ninguém cogita que possa precluir o direito do exequente requerer a penhora de um bem, muito menos que a penhora tenha de constar da sentença acobertada pela coisa julgada.

Os limites da coerção judicial, existentes principalmente em âmbito constitucional e jurisprudencial, tais como contraditório, juiz natural, publicidade, proporcionalidade e vedação ao enriquecimento sem causa ${ }^{473}$, estão relacionados mais ao devido processo legal, em sentido formal e substancial ${ }^{474}$, que a qualquer outro instituto relacionado ao mérito da causa ou às faculdades processuais das partes.

Destarte, independentemente do momento em que utilizada a tutela mandamental para efetivação dos direitos individuais homogêneos, fundamental será a observância do contraditório pleno e prévio, a fim de que não prevaleçam atos autoritários.

\footnotetext{
${ }^{472}$ Paulo Henrique dos Santos LUCON. In: Antonio Carlos MARCATO (Coord.). Código de Processo Civil interpretado, p. 1874. O autor observa que: "A multa periódica está fora do título e constitui legitima medida de coerção da qual o juiz pode valer-se para que a obrigação seja cumprida tal como determinado ou pactuado; por isso, a multa confere atributo mandamental ao provimento jurisdicional que se deseja ver atuado. Daí essa possibilidade de o julgador alterar seu valor sem que essa circunstância caracterize a modificação do que foi julgado. O que o ordenamento deseja é fazer com que o obrigado cumpra a obrigação exatamente como estabelecido no título".

${ }^{473}$ O STJ tem o entendimento consolidado no sentido de ser passível a revisão do valor da multa acumulada, quando capaz de gerar enriquecimento sem causa, ou por ser irrisória. Conferir o aresto proferido no Agravo Regimental no Agravo em Recurso Especial n ${ }^{\circ}$ 103853/SC, da lavra do Min. Sidnei Beneti, Terceira Turma, julgado em 27/03/2012 e publicado em 12/04/2012. Disponível em: www.stj.gov.br. Acesso em: 13 de jun. de 2012.

${ }^{474}$ Sobre o substantive dueprocess, consultar o julgamento da ADI $\mathrm{n}^{\circ}$ 173/DF, cuja relatoria coube ao Min. Joaquim Barbosa, realizado em 25/08/2008 e publicado 20/03/2009. Disponível em: www.stf.gov.br. Acesso em: 30 de out. de 2009. O devido processo legal substantivo se identifica com a ideia de razoabilidade e proporcionalidade, e seus respectivos postulados de adequação, necessidade e proporcionalidade em sentido estrito.
} 
Ainda que haja uma hipótese coletiva de urgência, o ideal é que o réu seja ouvido previamente sobre suas condições de satisfazes voluntariamente a obrigação; sendo efetivamente impossível a realização do contraditório, aí caberá ao juiz ter muito critério no exame dos requisitos antecipatórios e realizar uma ponderação de interesses, de maneira similar a realizada nos casos de risco de dano irreparável para ambas as partes, caso concedida ou negada a tutela antecipada ${ }^{475}$.

Registra-se ainda, a necessidade de que seja colocada em discussão nesse contraditório, questão relacionada ao prazo razoável para o cumprimento da decisão em favor dos seus beneficiários individualmente.

Obviamente, não se poderão manejar, na aplicação da técnica em questão, os prazos típicos da tutela individual, fazendo-se importante uma lembrança do que dispõe o $\S 4^{\circ}$ do artigo 461 do CPC, ao preceituar que a multa incidirá somente após o decurso de prazo razoável fixado pelo juiz, se a obrigação ainda não tiver sido prestada.

Percebe-se, que a vagueza da norma ao se utilizar do vocábulo razoável, concede ao magistrado a liberdade necessária ao exame em foco, para fixar um prazo dentro do qual seja possível o cumprimento de todas as obrigações, anteriormente às execuções individuais.

A necessidade de fixação de um prazo razoável, inexistente no direito positivo, decorre ainda do princípio da adequação, segundo o qual a técnica processual pode ser moldada às necessidades do caso concreto, respeitados os preceitos fundamentais do devido processo constitucional.

Nesse contexto, parece natural que o juiz não poderá fixar um prazo de 15 dias, para que o réu identifique, liquide e pague a todos os consumidores lesados por prática abusiva.

Elementos do caso concreto e suas características, tais como: os valores envolvidos, o número de pessoas beneficiadas, a dificuldade na organização das informações e até a situação financeira do réu, deverão ser objeto de consideração, tanto por parte do juiz que

\footnotetext{
${ }^{475}$ José Roberto dos Santos BEDAQUE. In: Antonio Carlos MARCATO (Coord.). Código de Processo Civil interpretado, p. 800. O autor se utiliza da garantia constitucional de acesso à justiça e efetividade, para afirmar que nesses casos o direito aparente tem de ser protegido, com uma necessária ponderação de valores e o recurso ao principio da proporcionalidade. Poderá o magistrado exigir caução, quando possível, a fim de assegurar eventual reparação no caso de modificação da decisão sumária.
} 
decidir, como pelas partes ao exercitarem o indispensável contraditório, com a respectiva produção de provas, se necessário.

Estando madura a questão do uso da tutela mandamental para ordenar o cumprimento de sentença coletiva sem demandas individuais, caberá ao juiz se utilizar da técnica, em caso de condenação, impondo um prazo razoável para o cumprimento da decisão, e uma sanção eficaz, ou seja, que não seja ínfima, para o caso de descumprimento.

Quanto à multa fixada para atender a pretensão em tela, mostra-se mais adequada à fixação de uma multa única e individual, que será cobrada por cada indivíduo obrigado a executar individualmente a sentença coletiva.

A multa diária com esse propósito poderia onerar demais o réu e mostrar-se causa de comportamentos sorrateiros, como os de autores que se acomodam com o descumprimento da decisão, na expectativa de acumular um grande valor de multa ${ }^{476}$.

Naturalmente, nada impedirá que nas execuções individuais se aplique multa diária, por exemplo, para a coação ao cumprimento de obrigação de fazer, ou nova multa única para se constranger a cumprir obrigação de não fazer, o que vai variar conforme a natureza do direito material ${ }^{477}$, sendo disciplinado pelos limites conhecidos atualmente nas hipóteses individuais.

Nas obrigações de pagar quantia, parece natural, que além da multa por permitir a execução individual da decisão coletiva, padecerá ainda o réu com a aplicação daquela prevista no artigo 475-J do CPC, que, como visto, possui escopo diverso, de impedir delonga no procedimento individual.

Portanto, a multa com o fim de obrigar o réu a cumprir decisão coletiva que reconheça direitos individuais homogêneos não poderá ser excessiva, para não criar um encargo insuportável para o réu, mas também terá de ser suficiente para estimulá-lo ao cumprimento da obrigação, ou seja, cumprir a decisão tem que valer mais a pena do que o contrário, sendo o alcance deste equilíbrio uma missão dificílima, mas que nem por isto pode ser refutada.

\footnotetext{
${ }^{476}$ FredieDIDIER JÚNIOR. "Multa coercitiva, boa-fé processual e supressio: aplicação do dutytomitigatetheloss no processo civil."Revista de Processo, p. 46-47.

${ }^{477}$ Teori Albino ZAVASCKI. “Antecipação de tutela e obrigações de fazer e de não fazer.”Revista Jurídica,p. 24.
} 
Por fim, registra-se a possibilidade de exclusão dessa multa fixada no título coletivo, sempre que o réu infirmar a execução individual por meio de impugnação ou outro meio, ou então, provar que se utilizou de todas as formas para identificar e satisfazer o beneficiário da sentença, encontrando óbices além dos razoáveis, por vezes impostos pelo próprio particular, propositalmente ou não.

Se o réu provar, por exemplo, que mandou correspondência ao indivíduo, comunicando-o de sua disposição de pagar uma indenização ou cumprir obrigação de fazer, não o tendo localizado, nem obtido resposta formal com informações necessárias ao depósito da quantia ou a realização de um fazer consubstanciado num serviço, deverá ser isentado da multa, pelo fato do propósito desta ter sido obstado por causas estranhas à vontade do devedor.

Em outros casos, como pagamento de reajuste a servidores, ou cumprimento de obrigação de não fazer consistente na extirpação de reajuste abusivo das contas dos clientes, dificilmente haverá casos de obstáculos ao cumprimento da decisão, seja pela natureza da obrigação, seja pelas características do vínculo existente entre a parte e os indivíduos.

\section{A REMESSA NECESSÁRIA COMO UMA GARANTIA EXTENSÍVEL A TODO PROCESSO COLETIVO EM QUE SE TENHA RESULTADO DESFAVORÁVEL À COLETIVIDADE}

A remessa necessária, requisito para que ocorra o trânsito em julgado de determinadas sentenças ${ }^{478}$, fora prevista expressamente na Lei de Ação Popular, em seu artigo 19, tanto para as hipóteses de improcedência, como para as hipóteses de carência de ação ou de extinção sem resolução do mérito por qualquer outra razão ${ }^{479}$.

\footnotetext{
${ }^{478}$ Rodrigo KLIPPEL. "Aspectos atuais sobre a remessa necessária."Revista da Procuradoria Geral do Estado do Espirito Santo, p. 58.

${ }^{479}$ Helena Najar ABDO; et al. In: Susana Henriques da COSTA (Coord.). Comentários à Lei de Ação Civil Pública e Lei de Ação Popular,p. 287.
} 
Não obstante, não há previsão de utilização dessa técnica na Lei de Ação Civil Pública, nem no Código de Defesa do Consumidor, leis importantes que constituem, juntamente com a Lei de Ação Popular e outras, o microssistema de tutela coletiva ${ }^{480}$.

Destarte, mostra-se pertinente e relevante o questionamento, sobre a possibilidade de se aplicar essa técnica, em outros casos envolvendo processos coletivos, que não por meio da Ação Popular.

Tal pergunta, além de se basear na omissão legislativa mencionada, tem aindaoutra raiz, lastreada na finalidade da remessa necessária, e repercutirá sobre a análise dos riscos da ampliação do uso do processo coletivo, interferindo, portanto, na análise das vantagens relacionadas à possibilidade de coletivização judicial de demandas individuais e da legitimidade individual para demandas coletivas.

Se pararmos para refletir no porquê de se exigir a remessa necessária, toda vez que a sentença reconheça a sucumbência do representante da coletividade, como nos casos da ação popular ou da ação coletiva visando à proteção de pessoa portadora de deficiência ${ }^{481}$, poderemos constatar que sua razão decorre do interesse público envolvido, consubstanciado na pretensão de tutela de um direito coletivo lato sensu, que se rejeitada, no mérito ou não, impactará sobre um grupo de pessoas ligadas por circunstancias fáticas, por uma relação jurídica base ou por direitos de origem comum.

Dessa maneira, para se reduzir o risco de sentenças injustas prejudicarem a coletividade, o legislador estabeleceu que a imutabilidade da sentença só será alcançada, respeitadas as técnicas secundumeventum litis e probationis, após o reexame da sentença pelo Tribunal de Justiça ao qual se submete o órgão prolator.

Nesse contexto, já se consegue reconstruir a questão inicialmente proposta, para que ela ganhe o seguinte formato: será que apenas os direitos tratados em ação popular, ou ação coletiva para proteção de pessoa portadora de deficiência, poderão ser mais protegidos, com a adoção obrigatória da remessa necessária?

Será que esses direitos são mais importantes que os direitos transindividuais tratados em outras demandas coletivas, como ações por improbidade administrativa, para a

\footnotetext{
${ }^{480}$ Rodrigo MAZZEI. “A ação popular e o microssistema da tutela coletiva.”Revista Forense,p. 270.

${ }^{481}$ Miriam Fecchio CHUEIRI; Emerson Cortezia de SOUZA. "A remessa obrigatória e as ações coletivas em espécie - Sistema processual coletivo de proteção ao interesse público.” Revista de Processo,p. 187.
} 
proteção do meio ambiente, do trabalhador ou do consumidor, justificando-se assim tal diferenciação no tratamento?

Para analisarmos essas questões, temos que tentar entender, que a remessa necessária ora estudada tem objetivos diferentes da remessa necessária decorrente da sucumbência da Fazenda Pública, já que esta tutela o interesse publico secundário, pertencente primeiramente à administração, enquanto aquela tutela o interesse público primário, diretamente ligado àcoletividade ${ }^{482}$.

A remessa necessária do processo coletivo, prevista na Lei de Ação Popular e na Lei que dispõe sobre os direitos da pessoa portadora de deficiência ${ }^{483}$, tem a finalidade de proteger direitos coletivos lato sensu, que pertençam diretamente a uma coletividade, que poderá ser em alguma medida prejudicada, em caso de sentença desfavorável, seja ela de mérito ou não, funde-se ela nas provas ou não.

Sendo assim, para mitigar os riscos da coletividade sofrer prejuízo injusto pelo uso do processo coletivo, onde os membros da coletividade não participam individualmente, $o$ legislador ampliou para esse âmbito a técnica da remessa obrigatória ou necessária.

Diante dessa analise teleológica, pode-se concluir que a remessa necessária deverá ser utilizada, sempre que for proferida sentença coletiva prejudicial ao interesse da coletividade representada, como um plusque a técnica processual oferece, para se evitar o cometimento de injustiças contra a coletividade abrangida por uma demanda coletiva.

Nesse ponto, poderia se questionar se a relevância do direito coletivo lato sensu objeto da demanda influenciaria na possibilidade de uso dessa técnica, ficando ela restrita as demandas coletivas que versem sobre matérias previstas na Lei de Ação Popular erário, meio ambiente, patrimônio estético, artístico, histórico ou turístico, ou na lei de proteção a pessoa portadora de deficiência.

Naturalmente, parece que o reconhecimento dessa garantia não deve se restringir às hipóteses de direitos coletivos lato sensu previstos nas normas mencionadas, pois assim se estabeleceria um grau de precedência entre tais direitos baseados exclusivamente na legalidade estrita, olvidando-se aspectos substanciais da questão, intrínsecos a valores constitucionais como justiça, isonomia e razoabilidade.

\footnotetext{
${ }^{482}$ Ibid., p. 170.

${ }^{483}$ Ibid., p. 187.
} 
Comopoderíamos dizer que a proteção do patrimônio artístico é mais importante do que a tutela dos consumidores, da criança e do adolescente, dos idosos, dos trabalhadores, das pessoas que disputam concursos públicos na mira de novas perspectivas de vida?

$\mathrm{O}$ argumento legalista não se mostra suficiente para restringir o uso de uma técnica salutar à segurança jurídica em casos coletivos, mesmo porque, isto iria de encontro com uma exegese finalística da norma.

Se o seu objetivo foi conferir maior segurança aos julgamentos que envolvam o interesse publico primário, não há como restringir a técnica apenas aos casos em que se discutam os direitos mencionados nas regras retro citadas, pois a complexidade fática é muito mais rica que um enunciado normativo, e novos interesses públicos primários surgem e se modificam a cada momento, todos eles com o mesmo, ou até maior grau de importância para o sistema jurídico pátrio.

Não obstante, deve-se reconhecer que alguns direitos coletivos lato sensu poderiam possuir menor grau de importância que os expressamente mencionados nas leis referidas, contudo, fazer um recorte com base numa gradação judicial, ameaçaria por demais a estabilidade almejada pela atividade jurisdicional, criando-se hipóteses demasiadas em que se poderia discutir a ocorrência ou não de coisa julgada, pelo fato de não ter havido remessa necessária.

Mostra-se fundamental, portanto, para que não se cometa um vilipendio a valores constitucionais e hermenêuticos, que a remessa oficial seja realizada sempre que houver uma sentença prejudicial aos interesses da coletividade, com ou sem julgamento de mérito, seja que ação coletiva for, seja que direito coletivo lato sensu for.

Tal conclusão pode ser sustentada ainda, com base numa interpretação sistemática da norma em questão, que a compreenda dentro do microssistema de processo coletivo, já que a normas que compõem esse complexo devem ser observadas em todos os casos, sempre que se mostrarem úteis e compatíveis com as normas especificas ${ }^{484}$.

\footnotetext{
${ }^{484}$ MAZZEI, op. cit. p. 272-273, nota 479.Segundo o autor: "De acordo com nossa posição, apesar da grande importância do Código de Defesa do Consumidor e da Lei da Ação Civil Pública, os dispositivos da Lei da Ação Popular (e os constantes das demais normas com vocação coletiva) poderão ser aproveitados em todo o microssistema coletivo, naquilo que for útil à efetivação da tutela de massa." E prossegue em parágrafo subsequente: "Obviamente, deverá o interprete aferir - em concreto - a eventual incompatibilidade e a especificidade de cada norma coletiva em relação aos demais diplomas, já que as leis que formam esse conjunto de regulação impar, sem exceção, interpenetram-se e subsidiam-se de forma harmônica, em especial no que concerne ao processo coletivo, em razão da dicção individual do Código de Processo Civil."
} 
Reconhecida mais essa garantia em favor da coletividade, se fortalecem, apesar de desnecessário, os argumentos favoráveis à legitimidade individual para demandas coletivas e, especialmente, à ampliação do uso do processo coletivo, por meio da coletivização de demanda individual, como forma de se proporcionar maior efetividade a tutela dos jurisdicionados.

\section{A IMPORTÂNCIA DOS MECANISMOS DE INFORMAÇÃO NO PROCESSO COLETIVO}

No contexto do presente trabalho, se mostra de suma importância um enfoque sobre os mecanismos que proporcionam informação aos indivíduos afetados, sobre a existência de um processo coletivo que os envolva e sobre a possibilidade deles participarem, para contribuir com um desfecho favorável ao grupo.

Já que se discutiu, ao longo do trabalho, vantagens e desvantagens relacionadas à coletivização de demandas individuais e à legitimidade individual para ações coletivas, mostra-se fundamental um debate, neste último tópico, sobre como os indivíduos poderiam 
ter conhecimento da existência do processo coletivo que pode lhes afetar e mais, tendo ciência, como poderiam interferir em beneficio próprio e da coletividade a qual pertencem.

Os mecanismos de informação do processo coletivo visam, primordialmente, a garantir aos indivíduos, e não somente à classe, um acesso à justiça pleno, substancial, onde eles possam participar, tendo preservado o seu dayincourt, ou seja, o direito de defenderem seus direitos no modelo do devido processo constitucional estabelecido.

Sendo assim, não há como divorciarmos a análise desses mecanismos de uma análise das vantagens e dos riscos do processo coletivo como um todo, pois se entende que, na medida em que o processo coletivo proporciona informação e chance de participação substancial e isonômica aos envolvidos, individualmente, ainda que de maneira limitada, os riscos de erro ou de prejuízo, que pudessem justificar o modelo individual de processo, ficam ainda mais reduzidos e com menor importância.

Dessa maneira, começa-se a análise em questão, pela compreensão dos mecanismos de informação voltados à ciência dos litigantes em geral, que não tenham demandas individuais ou pseudoindividuais ajuizadas sobre o tema.

\subsection{Os mecanismos de informação aos litigantes em geral e a necessidade de se possibilitar o litisconsórcio}

O primeiro mecanismo de informação do processo coletivo concerne àquele ligado à necessidade de publicação de edital sobre a demanda coletiva, para permitir a participação deco-legitimados e indivíduos como litisconsortes.

Apesar dos questionamentos sobre a natureza jurídica de tal intervenção, cujos reflexos incidiriam sobre a amplitude de poderes do interveniente, e apesar de haver entendimento no sentido de que, para os indivíduos, não seria caso de litisconsórcio, mas sim de assistência litisconsorcial, ousamos divergir e acreditar num verdadeiro 
litisconsórcio $^{485}$, mesmo entendendo que litisconsórcio e assistência litisconsorcial são institutos equivalentes ${ }^{486}$, mas operacionalizados de maneira diferente.

Nesse sentido, apesar do indivíduo não poder trazer a sua pretensão individual à baila $^{487}$, quanto à pretensão coletiva poderá ele agir como um litisconsorte, o que lhe possibilitará faculdades similares a de um assistente litisconsorcial, como requerer provas e oferecer recursos livremente.

Por esse rumo, somos obrigados a reconhecer até a possibilidade de aditamento da inicial, desde que respeitado o caráter coletivo da demanda e a sua estabilização ${ }^{488}$, como um consectário do litisconsórcio previsto em lei, pois do contrário teria sido prevista outra modalidade de intervenção.

Em segundo lugar, uma discussão ainda mais interessante se refere à necessidade de publicação de edital,para permitir o litisconsórcio individual em demandas versando sobre direitos difusos ou coletivos stricto sensu.

Para alguns, o litisconsórcio nesses casos só seria admitido por parte dos entes legitimados; ao individuo só seria permitido intervir nessas demandas como litisconsortes,

\footnotetext{
${ }^{485} \mathrm{O}$ autor RICARDO DE BARROS LEONEL admite a possibilidade de um genuíno litisconsórcio ulterior em demandas coletivas, mesmo por parte de indivíduos, que não têm legitimidade para a propositura isolada da demanda, o que, para ele, ficaria restrito aos casos de direitos individuais homogêneos. Nos casos envolvendo direito difuso ou coletivo stricto sensu, a formação de litisconsórcio pelo individuo só seria admitida se o objeto da demanda pudesse ser objeto de ação popular também. Ricardo de Barros LEONEL. Manual de processo coletivo,p. 246. No mesmo sentido: Rodolfo de Camargo MANCUSO. Ação civil pública: em defesa do meio ambiente, ..., p. 248-249. Autor que defende ser incabível o litisconsórcio ulterior do indivíduo, pela falta de legitimidade originária para a propositura da ação, defendendo tratar-se de assistência litisconsorcial: Marcelo ABELHA RODRIGUES. Ação civil pública e meio ambiente,p. 74. Já ANTONIO GIDI, mostra-se totalmente contrário à possibilidade de intervenção do individuo, mesmo em se tratando de ação coletiva sobre direitos individuais homogêneos, falando que até mesmo a intervenção dos co-legitimados teria natureza de assistência litisconsorcial. Ver mais em: Antonio GIDI. Coisa julgada e litispendência em ações coletivas, p. 56.

${ }^{486}$ Nessa linha ver: GIDI, op. cit. p. 56, nota 485. Para o referido autor: "Trata-se, portanto, do instituto da assistência litisconsorcial, que em tudo a lei equipara ao litisconsórcio, [...], podendo, inclusive, aditar a petição inicial e acrescentar novo pedido até a citação do réu (CPC, art. 264)." Sobre o assunto ver: Sérgio FERRAZ. Assistência litisconsorcial no direito processual civil,p. 69.

${ }^{487}$ LEONEL, op. cit. p. 246, nota 485.

${ }^{488}$ Ibid., p. 243. Importante registrar que o autor defende tal possibilidade de aditamento apenas para os colegitimados, senão vejamos: "Viável, assim, afirmar-se a possibilidade do litisconsórcio inicial ou ulterior por parte dos co-legitimados, inclusive com o aditamento da inicial, respeitando-se os limites que determinam a estabilização da demanda, em homenagem à economia processual e à pacificação social pelo preciso equacionamento do conflito coletivo".
} 
quando pudessem manejar ação popular com o mesmo objeto, pois aí haveria legitimidade individual que autorizasse o litisconsórcio ${ }^{489}$.

Nada obstante, entendemos injusta tal restrição, pois mesmo o objeto indivisível, caracterizador de um direito difuso ou coletivo stricto sensu, pertence, em alguma medida, ao individuo, de modo a se justificar o seu interesse na intervenção, afinal de contas, a quem pertence o ar que respiramos ${ }^{490}$ ?

Outro ponto que deve ser considerado nessa questão, é que a sentença coletiva, mesmo quando pertinente a objeto indivisível, poderá ser estendida in utilibus, para beneficiar as pretensões individuais a ela ligadas, o que robustece ainda mais o interesse do individuo na sua participação litisconsorcial ${ }^{491}$.

Outrossim, da mesma forma que o individuo não tem legitimidade expressa na lei para demandas envolvendo direitos difusos ou coletivos stricto sensu, também não o tem para demandas envolvendo direitos individuais homogêneos, mas nem por isto se discute o seu direito de intervir como nesse tipo de demanda, podendo-se, por analogia, estender essa faculdade as demais searas da tutela coletiva ${ }^{492}$.

Ainda que se fale que nos casos de direitos difusos ou coletivos stricto sensu não seria caso de se admitir o litisconsórcio individual, nem a assistência simples ${ }^{493}$, entendemos o contrário, pois materialmente o individuo é um codetentor do direito, que poderia ter levado o mesmo pleito ao Judiciário individualmente, em prestigio ao direito fundamental de acesso à justiça ${ }^{494}$.

Uma última questão de alta relevância sobre a temática concerne à possibilidade de limitação do litisconsórcio, para se evitar o chamado litisconsórcio multitudinário.

\footnotetext{
${ }^{489}$ Ver nota 485.

${ }^{490} \mathrm{O}$ autor desse clássico questionamento foi MAURO CAPPELLETTI, que pode ser conferido no seguinte artigo: Mauro CAPPELLETTI. "Formações sociais e interesses coletivos diante da justiça civil". Revista de Processo, p. 135. Defendendo a possibilidade de litisconsórcio individual em ações coletivas versando sobre direitos difusos ou coletivos stricto sensu:Elton VENTURI. Processo civil coletivo: a tutela jurisdicional ..., p. 317.Bruno Silveira de OLIVEIRA. "Flexibilização do binômio "processo tradicional" / "processo coletivo": breve análise ..." Revista da Procuradoria Geral do Estado do Espirito Santo,p. 73.

${ }^{491}$ VENTURI, op. cit. p. 321, nota 490.

${ }^{492}$ Ibid., p. 318.

${ }^{493}$ LEONEL, op. cit. p. 244, nota 485.No mesmo sentido: Antonio GIDI. Coisa julgada e litispendência em ações coletivas,p. 54. Para ANTONIO GIDI a intervenção nesses casos não será possível, mas se fosse, seria por meio da assistência simples.

${ }^{494}$ OLIVEIRA, op. cit. p. 68, nota 490.
} 
Naturalmente, não se pode permitir que todos os indivíduos interessados, intervenham como litisconsortes na demanda coletiva, sob pena de total esvaziamento do modelo coletivo de resolução de conflitos e equiparação deste a um grande litisconsórcio no processo individual ${ }^{495}$.

Nesse caso, a própria legislação do processo individual já reconhece o maleficio do litisconsórcio composto por um número excessivo de partes, que pode prejudicar a defesa ou o bom andamento do processo, prevendo o poder do juiz excluir da lide os indivíduos que extrapolarem o número aceitável.

Aliás, justamente para essas hipóteses é que serve o processo coletivo, ou seja, para permitir que o processo envolvendo um número excessivo de partes materiais, possa se desenvolver de maneira efetiva, sem precisar abarcar a todas como partes formais, cabendo a um representante a defesa dos interesses alheios.

Nesse caso, ainda que se fale da importância do acesso à justiça de todos os indivíduos afetados, também é certo que ninguém terá acesso efetivo se todos quiserem ser partes da mesma demanda, situação fática que justifica a restrição ${ }^{496}$, podendo o individuo que ficar excluído da lide coletiva, adotar as suas providências individuais para a proteção dos seus direitos.

Eventuais direitos indivisíveis, como já são objetos de demanda coletiva, não precisarão ser objeto de demanda pseudoindividual, que deverá ser considerada desnecessária.

Apesar de se considerar importante a participação do indivíduo afetado no processo coletivo, pois ele, como afetado, às vezes possui mais interesse e meios de contribuir com o julgamento do que qualquer outro legitimado ${ }^{497}$, não se pode considerar que todos precisem de participar, mesmo porque, a participação de alguns já será suficiente para que todos os argumentos e todas as provas sobre o caso sejam analisadas e submetidas a julgamento.

Sendo assim, caberá ao juiz, no caso concreto, limitar o número de litisconsortes individuais no processo coletivo, seja ele relativo a objeto individual homogêneo ou indivisível, visando, com isto, à conciliação do direito fundamental de acesso à justiça dos

\footnotetext{
${ }^{495}$ Ibid., p. 88-89.

${ }^{496}$ Ibid., p. 89.

${ }^{497}$ Ibid., p. 71 .
} 
afetados, com o direito fundamental de acesso à justiça da classe à qual pertence o indivíduo, quando se mostrar desnecessária a participação do indivíduo, pela existência de muitos que já estão desempenhando a defesa do grupo, ficando a via individual aberta, para àqueles que optarem por ela, para a proteção dos seus direitos individuais.

\subsection{Os mecanismos de informação aos litigantes que tenham ajuizado demandas individuais, a importância da cooperação do réu e a proteção das pessoas que não fruíram da devida informação}

Conforme preceitua o artigo 104 do CDC, de maneira, aliás, totalmente confusa, a ponto de merecer inúmeros estudos e interpretações a respeito ${ }^{498}$, para que os indivíduos que ajuizaram demandas individuais se beneficiem dos efeitos positivos de uma ação coletiva correspondente à sua pretensão individual, deverão requerer a suspensão do seu processo e aguardar a decisão coletiva.

Apesar da confusão feita pelo referido dispositivo, com relação aos incisos dos artigos 103 e 81 do CDC, grande parte da doutrina entende hoje que esse dispositivo se aplica a todo caso de ação coletiva, verse ela sobre direitos difusos, coletivos stricto sensu ou individual homogêneo ${ }^{499}$, o que parece totalmente correto, pois não haveria sentido ou razão que justificasse a restrição contida numa interpretação literal.

Sendo assim, estando em tramite uma ação coletiva que verse sobre direito difuso, como, por exemplo, uma ação que vise à interrupção de uma conduta que cause danos ao meio ambiente, bem como ações individuais por meio das quais se pretenda indenização por eventuais danos decorrentes dessa conduta, esses indivíduos precisam requerer a suspensão de suas demandas individuais para se beneficiarem da extensão in utilibusdo julgado coletivo, prevista no $\S 4^{\circ}$ do artigo 103 do $\mathrm{CDC}^{500}$.

\footnotetext{
498 Antonio GIDI. Coisa julgada e litispendência em ações coletivas,p. 208-217.

${ }^{499}$ Ibid., p. 217-218.

${ }^{500}$ Ibid., p. 218. Igualmente: Elton VENTURI. Processo civil coletivo: a tutela jurisdicional ..., p. 352.
} 
Dessa maneira, a mesma conduta será devida em se tratando de direito coletivos stricto sensu ou individuais homogêneos ${ }^{501}$.

Nesse cenário, questão interessante que se apresenta, concerne à hipótese de tramite simultâneo entre uma ação coletiva versando sobre direito difuso, por exemplo, e uma ação pseudoindividual, baseada nos mesmos fatos e pedidos.

Nesse caso, naturalmente, não seria pertinente a aplicação do dispositivo em apreço, que recai sobre demandas genuinamente individuais, sendo adequado o reconhecimento de litispendência, com a eventual reunião dos processos, se isto não redundar num litisconsórcio multitudinário, como será visto no tópico seguinte.

Já no que tange à questão do tramite simultâneo de demandas genuinamente individuais e uma ação coletiva, interessante registrar que o STJ, em recente precedente sobre o tema, decidiu pela obrigatoriedade da suspensão dos feitos individuais correspondentes a pleito coletivo, enquanto se aguarda seu julgamento mediante sentença coletiva, confirmando acórdão oriundo do TJ do Rio Grande do Sul ${ }^{502}$.

O fundamento de tal decisão se baseia numa interpretação finalística e sistemática da regra dos recursos repetitivos ${ }^{503}$, já que não existe previsão legal especifica para o caso, nos parecendo uma medida interessante, apesar das criticas sofridas $^{504}$,poismesmolimitando o direito individual de prosseguir com a demanda, não nega o direito fundamental de acesso à justiça, na medida em que apenas tenta uniformizar e dotar de mais eficiência a atividade jurisdicional, que, como dito no inicio do trabalho, merece uma reformulação e uma adequação aos novos formatos sociais e tipos de conflitos.

Prosseguindo no exame do instituto, esclarece-se, que diferentemente das outras hipóteses legais de suspensão, feita a opção do indivíduo pela suspensão de sua demanda

\footnotetext{
${ }^{501}$ Ibid., p. 218. Do mesmo modo: VENTURI, op. cit. p. 352, nota 500.

${ }^{502}$ Alexandre Grandi MANDELLI; José Maria TESHEINER. "Litispendência em processos coletivos e individuais.” Revista Jurídica,p. 62.

${ }^{503}$ Ibid., p. 62.

${ }^{504}$ Sobre as criticas ver: Marcelo José Magalhães BONICIO. Análise da tendência jurisprudencial de potencialização dos efeitos da regra prevista no art. 543-C do CPC. Artigo ainda não publicado. Ver também: Felipe Silva NOYA. "O REsp 1.110.549 à luz do devido processo legal: o acesso à justiça individual frente às ações coletivas.” Revista de Processo, p. 373.
} 
individual, esta permanecerá suspensa até o julgamento final da demanda coletiva ${ }^{505}$, o que, contudo, não impede a parte de se arrepender e requerer o retorno do trâmite de sua demanda individual, quando demorar por tempo excessivo o julgamento do processo coletivo ou for proferida sentença coletiva desfavorável à coletividade ${ }^{506}$.

Nesse sentido, para que o indivíduo possa fazer sua escolha sobre a suspensão ou não, deverá ele ser intimado especificamente para tanto, dando-lhe ciência da existência do processo coletivo e da necessidade de suspensão para a extensão útil do respectivo resultado $^{507}$.

Tal intimação, assim como o arrependimento, poderão se dar a qualquer momento, até o transito em julgado da demanda individual ${ }^{508}$, não havendo óbice pelo fato de uma das demandas já ter sido sentenciada, encontrando-se em grau de recurso, mesmo porque a lei não coloca esse óbice, não podendo o Judiciário extrair resultados extensivos da atividade interpretativa, para restringir direitos, mormente quando isto não oferecer qualquer contrapartida benéfica.

Quanto à obrigação de proporcionar a informação no processo individual, sobre a existência da demanda coletiva, parece natural que tal dever caiba ao réu da demanda coletiva, que será o mesmo réu da demanda individual ${ }^{509}$, já que o magistrado, também incumbido dessa tarefa, nem sempre terá condições de assim proceder.

Nesse sentido, em caso de inobservância desse dever, o indivíduo deverá se beneficiar do resultado da demanda coletiva de qualquer modo, pois do contrário haveria um estímulo para o réu manter-se omisso e aguardar o julgamento individual.

Outrossim, a regra do artigo 104 do CDC condiciona a extensão útil à opção pela suspensão do processo individual, apenas nas hipóteses em que o indivíduo for cientificado da demanda coletiva e decidir conscientemente pelo prosseguimento da causa individual, o que nos permite concluir que, caso ele não seja cientificado e, portanto, não possa optar

\footnotetext{
${ }^{505}$ GIDI, op. cit. p. 193 , nota 498.

${ }^{506}$ Ibid., p. 198 e 205.

${ }^{507}$ Sobre a necessidade de intimação para caracterização do termo inicial do prazo: Ibid., p. 200.

${ }^{508}$ Ibid., p. 199. Ver também: VENTURI, op. cit. p. 365, nota 500.

${ }^{509}$ Ibid., p. 202. Para o autor: "Portanto, incumbe ao próprio fornecedor informar ao consumidor sobre a existência de ação coletiva contra si proposta com objeto correspondente ao da ação individual. Só assim o consumidor poderá realizar a opção concedida pela lei”. Em rumo convergente: Elton VENTURI. Processo civil coletivo: a tutela jurisdicional ..., p. 354-355.
} 
com consciência pela suspensão ou não, deverá ele se beneficiar do resultado de qualquer $\operatorname{modo}^{510}$.

A única restrição a tal posicionamento seria a ocorrência de coisa julgada desfavorável no processo individual, anterior a informação sobre o processo coletivo, o que consubstanciaria uma hipótese de ação rescisória pela violação a literal disposição de lei, já que esta impõe a comunicação ao individuo, para que ele exerça o direito de optar conscientemente pela suspensão ou não ${ }^{511}$.

Conclui-se assim, ser imprescindível a colaboração do réu no processo coletivo e individual, para a perfeita aplicação prática do dispositivo em comento, sob pena de, se assim não proceder, também não poder se beneficiar de sua má-fé.

\subsection{A ideia do cadastro nacional de processos coletivos e a alegação de conexão, continência, litispendência e coisa julgada}

O cadastro nacional de processos coletivos é algo que já deveria ter sido colocado em prática nesse modelo molecularizado de resolução de conflitos, mostrando-se essencial para permitir ao magistrado o conhecimento de ofício de matérias como conexão, continência, litispendência e coisa julgada, que têm em comum o objetivo de evitar conflitos teóricos e práticos entre decisões judiciais, bem como a repetição de atividades desnecessárias, seja pela identidade parcial de demandas (conexão e continência), seja pela identidade total (litispendência e coisa julgada) ${ }^{512}$.

Tais institutos, que contribuem para a segurança e economia da atividade jurisdicional, para serem reconhecidos dependem do exame comparativo dos elementos de duas ou mais ações, que poderão ser reunidas (nos casos de conexão e continência) ou ter o seguimento interrompido para uma delas (nos casos de litispendência e coisa julgada).

\footnotetext{
${ }^{510}$ Ibid., p. 202-203. Igualmente: VENTURI, op. cit. p. 365, nota 509.

${ }^{511}$ Ibid., p. 204. Do mesmo modo: VENTURI, op. cit. p. 366, nota 509.

${ }^{512}$ Ricardo de Barros LEONEL. Manual de processo coletivo,p. 249-250. Para se aprofundar no tema, ver também: Cassio Scarpinella BUENO. Curso sistematizado de direito processual civil: teoria geral do direito processual civil, p. 415-417. Cassio Scarpinella BUENO. Curso sistematizado de direito processual civil: procedimento comum: ordinário e sumário, 2: tomo I. p.73-75.
} 
Os elementos da ação, como é sabido, são as partes, a causa de pedir e o pedido, sendo certo, que o cadastro nacional permitiria a todo magistrado, ao se deparar com uma ação coletiva - ou qualquer ação, pesquisar a existência de outra demanda coletiva, com a mesma causa de pedir ou pedido, reconhecendo assim a ocorrência de algum desses fenômenos.

Nesse sentido, verificada a existência de demandas coletivas com identidade de causa de pedir ou de pedido, deverão os processos ser reunidos por conta da conexão ${ }^{513}$.

Apesar de alguém poder sustentar que tal reunião estaria limitada pela competência territorial dos órgãos jurisdicionais, que no processo coletivo é absoluta e denominada pela própria lei como funcional, não concordamos com tal pensamento, já que a competência será definida pela extensão do dano e, se os processos tiverem a mesma causa de pedir (remota, ou seja, intersecção fática) ou o mesmo pedido (mediato, ou seja, o bem da vida), o órgão jurisdicional territorialmente competente para um será também o competente para o outro, ainda que situados em estados diferentes, pois a extensão dos danos propiciará tal situação.

Assim sendo, por exemplo, se uma demanda coletiva tramita na capital do Rio de Janeiro e a outra na capital de São Paulo, tendo em comum os mesmos fatos, que tem repercussão regional ou nacional, ambos os órgãos têm competência concorrente e, portanto, não haverá óbice a reunião dos processos.

$\mathrm{O}$ argumento de que a coisa julgada de um ficaria restrita ao Estado onde se encontra situado o órgão jurisdicional já foi rebatido no presente trabalho e afronta a própria ideia de competência baseada na extensão dos danos ${ }^{514}$; se o órgão é competente para julgar causa com repercussão nacional, a sua decisão deverá ter a mesma repercussão, sob pena de ineficácia parcial e impertinência da norma sobre competência.

\footnotetext{
${ }^{513}$ Ibid., p. 252.

${ }^{514}$ Apesar do nosso posicionamento, a doutrina noticia decisão do STJ de 2011, por meio da qual se reconheceu a inocorrência de litispendência entre ações coletivas idênticas, que tramitavam em Estados diferentes. Conferir em: Alexandre Grandi MANDELLI; José Maria TESHEINER. "Litispendência em processos coletivos e individuais." Revista Jurídica,p. 58. Em sentido convergente com o adotado nesta tese, sobre a ineficácia da restrição territorial à coisa julgada coletiva: Ada Pellegrini GRINOVER. "Ação civil pública refém do autoritarismo." Revista de Processo, p. 34.
} 
Além disso, em se tratando de ações cujo objeto seja bem indivisível, será inviável a cisão dos efeitos da decisão para restringi-los a um único Estado da Federação ${ }^{515}$, não havendo como se falar em impedimento na reunião por conexão; podemos citar como exemplos neste ponto, as ações populares, para anulação da privatização da antiga Companhia Vale do Rio Doce.

A mesma ideia serve para os casos de continência, onde se tem identidade de partes e causa de pedir, mas os pedidos de uma encontram-se contidos na outra, que é mais ampla.

Deve-se apenas registrar que, em se tratando de processos coletivos, não nos cabe falar em identidade de partes no mesmo sentido do processo individual, mas sim em partes materiais, ou seja, identidade de pessoas afetadas pela atuação jurisdicional esperada, e não em identidade de partes formais, pouco importando quem seja o legitimado autor da ação ${ }^{516}$.

Além disso, destaca-se a possibilidade de reunião por conexão, e não por continência $^{517}$, de demandas individuais às coletivas, versem estas sobre direitos difusos, coletivos stricto sensu ou individuais homogêneos, que atrairiam a competência, desde que isso não represente prejuízo ao andamento dos $\operatorname{processos}^{518}$ e à atuação das partes individuais, que poderiam ter a defesa dos seus direitos dificultada pela distância territorial, pelo estágio do processo coletivo ou pela sua complexidade.

Outrossim, deve-se observar, que a reunião de processos individuais aos coletivos terá de ser limitada pelas mesmas razões que limitam o litisconsórcio multitudinário, já que seria impensável e até mesmo contraditório, admitir um processo coletivo com milhares de demandas individuais conexas; não à toa, o legislador previu o mecanismo de suspensão dos processos individuais conexos com demandas coletivas.

No que tange a litispendência, devem ser tecidas considerações similares, ou seja, verificando o magistrado, por meio do cadastro nacional, a existência de demandas coletivas idênticas, deverá ser reconhecida a litispendência, que em nossa ótica, em se

${ }^{515}$ BRASIL. CC 109435 / PR, Conflito de Competência 2009/0240560-8, Min. Napoleão Nunes Maia Filho, S3 - Terceira Seção, data do julgamento: 22-09-2010, data da publicação: DJe 15-12-2010. Disponível em: www.stj.jus.br. Acesso em: 22 de julho de 2014.

${ }^{516}$ Alexandre Grandi MANDELLI. José Maria TESHEINER. "Litispendência em processos coletivos e individuais." Revista Jurídica,p. 55-56. No mesmo sentido: LEONEL, op. cit. p. 253, nota 512.

${ }^{517}$ LEONEL, op. cit. p. 255-256, nota 512.

${ }^{518}$ Ibid., p. 256-257. 
tratando de processos coletivos, deverá redundar na reunião dos processos e não na extinção daquele ajuizado por último ${ }^{519}$.

Esse entendimento se funda no fato de que, como as partes formais no processo coletivo podem ser diferentes, naturalmente elas poderão trazer argumentos e provas diferentes, relevantes para a obtenção da decisão jurisdicional mais justa possível ${ }^{520}$.

Outrossim, se o autor da segunda demanda poderia intervir na primeira como litisconsorte, com base em expressa autorização legal, porque não admitir a reunião por litispendência? Do contrário, ou seja, com a extinção do segundo processo, o autor deste apenas seria forçado a ingressar como litisconsorte na primeira, caso efetivamente quisesse participar.

A única limitação que deverá ser observada concerne ao fato, de que a reunião deverá ser restringida pelas mesmas razões práticas que disciplinam o litisconsórcio multitudinário, ou seja, caso o número excessivo de partes prejudique o andamento do feito ou a defesa das partes, deverá haver a extinção das demandas propostas posteriormente e não mais a reunião.

Se a litispendência ocorrer entre uma ação coletiva e uma pseudoindividual, caso não seja possível mais a reunião, pelo excesso de processos reunidos, esta última deverá ser extinta, ainda que aparente ter sido proposta anteriormente, devendo prevalecer a que primeiro foi concebida no formato coletivo, por se mais adequada aos fins jurisdicionais de segurança e economia.

Mais uma vez aqui, deve-se registrar que a identidade das partes se dará pela ótica da relação jurídica material, e não processual ${ }^{521}$.

Quanto à questão dos limites territoriais da coisa julgada, que, como visto, já foram entendidos como óbice ao reconhecimento da litispendência ${ }^{522}$, pensamos ser equivocada tal compreensão, uma vez que, insista-se, a competência será determinada pela extensão

\footnotetext{
${ }^{519}$ No mesmo sentido: Gregório Assagra de ALMEIDA. Direito processual coletivo brasileiro: um novo ramo do direito processual (princípios, ...), p. 360-361. Em sentido contrário: LEONEL, op. cit. p. 253, nota 513. Antonio GIDI. Coisa julgada e litispendência em ações coletivas, p. 223-224. Elton VENTURI. Processo civil coletivo: a tutela jurisdicional ..., p. 333-334.

${ }^{520}$ ALMEIDA, op. cit. p. 360-361, nota 519. Para exemplificar, o autor menciona a hipótese de uma ação civil pública, precedida de um criterioso inquérito civil, que tramite simultaneamente a uma ação popular idêntica, com prevenção por ter sido ajuizada anteriormente.

${ }^{521}$ GIDI, op. cit. p. 219, nota 519.

${ }^{522}$ MANDELLI; TESHEINER, op. cit. p. 58, nota 516.
} 
dos danos, de modo que o juiz de um Estado terá competência para julgar causas com repercussão nacional, sendo inadmissível a restrição da eficácia da sua decisão, já que ele tem competência para julgar o litígio ${ }^{523}$.

Outrossim, em muitas hipóteses, pela indivisibilidade do objeto, se mostrará impossível, na prática, a observância da limitação colocada pelo artigo 16 da Lei de Ação Civil Pública, como visto acima.

Jamais haverá litispendência entre demanda coletiva e individual, a não ser que se trate de demanda pseudoindividual, problema este que deverá ser resolvido da mesma forma proposta para a litispendência entre demandas coletivas, ou seja, com a tentativa de reunião.

Uma última questão sobre esse assunto, que se apresenta interessante, é a possibilidade de se reconhecer a litispendência entre uma demanda coletiva versando sobre direitos difusos e outra versando sobre direitos individuais homogêneos, com a qual alguns autores concordam, sob o argumento de que seria desnecessário o tramite simultâneo das duas demandas, já que a demanda sobre direito difuso abrangeria a pretensão sobre direitos individuais homogêneos, podendo o seu resultado ser aproveitado pelos indivíduos com pretensões individuais correspondentes ${ }^{524}$.

Contudo, não concordamos com tal posicionamento, primeiro porque não se trata de total identidade entre as demandas, o que seria necessário para a configuração da litispendência, segundo porque, ainda que houvesse total identidade, como falamos anteriormente, a solução ideal nos parece a tentativa de reunião das demandas e não a extinção da que verse sobre direitos individuais homogêneos, mesmo porque, se esta tiver sido proposta primeiro o seu juízo estará prevento.

Nesses casos, parece-nos mais adequado o reconhecimento de conexão, já que, havendo identidade de partes materiais e causa de pedir, os pedidos contidos nas demandas são diferentes, não se podendo falar em pedido implícito de condenação genérica, pois a improcedência da ação que verse sobre direitos transindividuais não terá o condão de impedir uma futura ação versando sobre direitos individuais homogêneos ${ }^{525}$.

\footnotetext{
${ }^{523}$ Ada Pellegrini GRINOVER. “Ação civil pública refém do autoritarismo.” Revista de Processo, p. 34.

${ }^{524}$ Por esse rumo: VENTURI, op. cit. p. 337, nota 519.

${ }^{525}$ GIDI, op. cit. p. 221 , nota 519 .
} 
Entende-se então, pela impossibilidade de se falar em litispendência nesses casos, sendo mais correta a reunião por conexão, até porque, novamente não seria razoável interpretação com resultado extensivo, para o fim de restringir direitos com a extinção de processos por litispendência.

Por fim, frisa-se a importância do cadastro nacional de processos coletivos também para o reconhecimento liminar de coisa julgada sobre o objeto de ação coletiva, já que, permitindo ao juiz a comparação entre os elementos de duas demandas, de plano ele já poderia aferir o óbice legal da coisa julgada e extinguir o segundo processo sem resolver o mérito, ganhando em economia e celeridade.

Conclui-se assim, pela imprescindibilidade de um sistema nacional integrado que permita a operacionalização eficaz dos processos coletivos em todo o território nacional, elidindo, com isto, ou pelo menos reduzindo, o risco de contradições teóricas e práticas entre decisões judiciais, bem como a repetição desnecessária de atos já realizados.

\section{CONCLUSÃO}


Encerrando a presente pesquisa, que se desenvolveu sobre o problema concernente à possibilidade de coletivização judicial de demandas individuais, no intuito de se ampliar a utilização do processo coletivo e, com isto, se reduzir o volume de demandas individuais repetitivas ou que tenham por objeto direito indivisível, ganhando-se em economia processual, celeridade e segurança, podem ser erigidas algumas conclusões genéricas e centrais, sintetizadas nos três pontos que seguem:

1 - A coletivização judicial de demandas individuais se apresenta, para nós, como um eficiente mecanismo de ampliação do uso do processo coletivo, resultado que, pode-se afirmar com base na pesquisa realizada, proporcionará economia processual, com a centralização do procedimento e do julgamento de casos individuais repetitivos ou que versem sobre direito indivisível, e acréscimo de segurança, com a redução do risco de incompatibilidade prática entre decisões contrárias sobre direitos indivisíveis e, também, com a ampliação do acesso à justiça envolvendo direitos que muitas vezes não seriam objeto de tutela jurisdicional, seja pelo seu baixo valor econômico, seja pela dificuldade envolvida na condução de uma demanda em juízo, situação que acaba por desestimular muitas pessoas a adotarem tal providência.

Não obstante, reconhece-se que, no atual contexto cultural, apesar de sermos simpáticos a ideia de adoção de tal técnica com base nos princípios constitucionais e na instrumentalidade do processo, mostra-se necessária a criação de lei, estabelecendo a forma pela qual essa coletivização será realizada, as hipóteses em que poderá ocorrer, os requisitos que deverá observar, os limites e as consequências da sua adoção.

Aliás, ficou registrada na pesquisa a existência dessa técnica no projeto de lei $n^{\circ}$ 8.046/2010 aprovado na Câmara dos Deputados, que dispõe sobre o novo Código de Processo Civil, todavia, vimos também que a disposição mencionada mostra-se altamente insatisfatória, mormente quando não admite que a coletivização se dê de oficio e a exclui para o caso de direitos individuais homogêneos.

2 - A legitimidade individual para demandas coletivas é um importante pressuposto para que a técnica de coletivização de demandas individuais alcance todo o seu potencial, na medida em que permite à parte individual prosseguir no processo coletivizado e impede que a coletivização fique subordinada ao consentimento dos entes expressamente legitimados na lei. 
Apesar da LACP e o CDC não terem incluído o individuo no rol expresso de legitimados para o ajuizamento de ação coletiva, essa legitimidade pode ser extraída de uma interpretação sistemática do ordenamento jurídico, que prevê a ação popular com um rol vastíssimo de cabimento, a ação penal subsidiaria da pública, como hipótese de tutela de bem difuso pelo individuo, além de outras hipóteses em que o indivíduo pode, isoladamente, demandar por bens indivisíveis, como um consectário do direito fundamental de acesso à justiça, não havendo racionalidade em se dizer que para todas essas hipóteses o indivíduo tem legitimidade, mas para outras, muitas vezes ontologicamente similares, ele não tenha.

3 - Por fim, como resultado dessa coletivização, espera-se a consecução do objetivo de se obter a redução do número de processos individuais repetitivos, lastreados em direitos individuais homogêneos, bem como a redução de risco de incompatibilidade prática entre julgados envolvendo bens indivisíveis, além de um maior grau de acesso à justiça para a tutela de bens de valor insignificante, ou ainda para alcançar pessoas que teriam mais dificuldade em sustentar uma demanda judicial em tramite na justiça.

No campo dos direitos individuais homogêneos, é preciso que esse termo seja compreendido numa acepção ampla, a ponto de envolver todo direito baseado numa origem comum, seja ela fática ou jurídica, tenham as demandas predominância de questões comuns ou não, pois mesmo nestes casos, a demanda coletiva terá o condão de proporcionar alguma economia processual para os casos individuais, com a redução de discussões fáticas, que se resumirão ao nexo causal nas liquidações individuais.

Outrossim, o próprio fato de ser necessária, muitas vezes, a realização de liquidação e execução individual para a efetivação plena do direito individual homogêneo não infirma os benefícios auferidos com o uso da tutela coletiva, primeiro porque a liquidação já se apresenta numa formatação mais simples que um processo de conhecimento comum, onde se tenha que discutir a própria existência do direito e a ocorrência de um fato principal; segundo porque os casos em que se mostra necessária a liquidação e a execução individual podem ser reduzidos, caso se utilize a tutela mandamental, para obrigar os réus condenados em processos coletivos, a cumprir espontaneamente os direitos individuais reconhecidos numa sentença de procedência, quando o réu possua uma relação jurídica continuativa com os indivíduos envolvidos na questão, que lhe permita identifica-losjuntamente com o valor, o fazer ou o não fazer correspondente, tenha ela natureza consumerista, administrativa, trabalhista ou mesmo cível. 
As conclusões gerais acima delineadas estão calcadas sobre premissas específicas, que ficaram assentadas ao longo da pesquisa e podem ser sintetizadas nos seguintes tópicos:

4 - A massificação de demandas repetitivas ou envolvendo bens indivisíveis é uma realidade atual, comprovada mediante dados fornecidos por pesquisa do CNJ, que demonstra o fato de setores específicos, como a fazenda pública, as instituições financeiras e as empresas de telefonia, serem responsáveis pela maioria das demandas pendentes de julgamento no Judiciário, o que se traduz em milhares de demandas individuais repetitivas ou versando sobre bens indivisíveis, que poderiam ser tratadas de maneira coletiva.

5 - O processo coletivo tem o escopo e a aptidão de proporcionar celeridade processual, na medida em que proporciona o maior alcance da tutela jurisdicional, com a consequente redução do número de processos, sem falar na redução do risco de conflitos práticos entre julgados sobre bens indivisíveis e a ampliação do acesso à justiça.

6 - Nesse cenário, a técnica de coletivização de demandas individuais se mostra importante, na medida em que permite a uma ampliação do uso do processo coletivo e, consequentemente, dos seus efeitos positivos.

7 - Quando da coletivização de uma demanda judicial, na decisão, que será precedida de um contraditório, deverá necessariamente constar manifestação expressa sobre: que tipo de direito coletivo lato sensu foi identificado pelo juiz, a utilidade do processo coletivo diante da numerosidade do grupo afetado, qual é o grupo afetado e se o autor da ação pertence a esse grupo, quais pedidos estão sendo coletivizados e quais os fundamentos destes.

8 - A representatividade adequada não deverá ser objeto de aferição pelo juiz quando da coletivização de uma demanda, já que seria discriminatório se restringir a legitimidade do individuo com base em critérios econômicos ou de experiência, sendo desnecessário tal exame, ante as inúmeras garantias que existem no sistema brasileiro, mormente o fato da coisa julgada nunca prejudicar direitos individuais e a coisa julgada sobre direitos indivisíveis ser sempre secundumeventumprobationis, isso sem contar a participação obrigatória do Ministério Público, que é um ente legitimado expressamente pela lei.

9 - A identificação de um direito como individual homogêneo não dependerá de dilação probatória, cabendo ao juiz, com base nos fatos afirmados na inicial e nos 
documentos apresentados liminarmente, aferir, levando em conta as máximas de experiência, se aquela situação é homogênea a de inúmeros outros indivíduos, a ponto de justificar a coletivização, exame que deverá ocorrer de maneira similar, quando for necessária análise da utilidade do processo coletivo para hipóteses envolvendo direitos indivisíveis.

10 - A coletivização da demanda individual poderá ocorrer em qualquer fase do processo, desde que não redunde em atraso relevante, pela necessidade de prática de atos complexos, que no modelo individual não seriam necessários, ou pela repetição de atos já praticados, a não ser que, mesmo diante de tais fatores o autor concorde com a coletivização, sendo certo, que sempre deverá haver contraditório antes da coletivização e, posteriormente, tem que ser dada oportunidade das partes produzirem provas sabendo que participam de um processo coletivo.

11 - Coletivizada uma demanda individual, não será necessário o oferecimento de emenda a inicial, seja porque tal providência não terá o condão de beneficiar o contraditório, mesmo porque a decisão judicial já fará constar todas as informações necessárias a defesa, tais como os pedidos coletivizados e seus respectivos fundamentos, seja porque a dependência de uma emenda poderia prejudicar a utilização da técnica.

12- A conversão de uma demanda individual em coletiva só poderá ocorrer se o juiz que pretendê-la tiver competência para o julgamento do processo no formato coletivo. Caso contrário haverá nulidade, podendo-se aproveitar o capítulo individual da sentença.

13- Não haverá coletivização de demanda individual, se esta resultar em demora excessiva para a parte, pela necessidade de se praticar atos que não seriam necessários no modelo individual, ou pela necessidade de repetição de atos que já foram praticados no processo individual, se o juiz não tiver competência para julgar a demanda coletivizada, se houver litispendência ou coisa julgada.

14-Havendo cumulação de pedidos coletivizáveis com pedidos individuais que não serão objeto de coletivização, o juiz deverá conduzir a instrução conjuntamente, proferindo, ao final, sentença com capítulos diferentes, que abranjam todo o litígio, sem a necessidade dos pedidos individuais prosseguirem em autos apartados.

15- Não caberá ao autor da demanda individual concordar ou não com a coletivização, visto que esta não prejudicará em nada suas faculdades processuais de transigir, renunciar ou desistir da sua parcela da pretensão, nem lhe acrescerá custos, sendo 
inútil eventual opção, principalmente se pensarmos que o processo individual dele poderia ser apensado por conexão a outro coletivo, ou ainda poderá sofrer a suspensão coercitiva pelo tramite de demanda coletiva correspondente, conforme entendimento sedimentado em recurso repetitivo julgado pelo STJ.

16 - Seria viável falarmos em coletivização para que a coletividade figure no polo passivo, igualmente ao que ocorre com as ações coletivas passivas, mas apenas em se tratando de pretensões envolvendo direitos indivisíveis, que possuem o regime de coisa julgada secundumeventumprobationis, pois do contrário, se o caso envolver direitos individuais, a coletivização não poderá ocorrer com a coletividade no polo passivo, pois não se admitiria que sua coisa julgada afetasse os respectivos direitos individuais, restando inútil a utilização de tal técnica.

17-Coletivizada uma demanda individual, seria interessante que todas as demandas individuais correspondentes ficassem suspensas, na forma como decidido pelo STJ em recurso repetitivo, trate a ação coletiva de direito difuso, coletivo ou individual homogêneo. Em existindo ações pseudoindividuais com objeto coincidente com de ação coletiva, deverá ser reconhecida a litispendência com a reunião das demandas, quando possível, ou extinção da pseudoindividual em prestígio a que primeiro foi coletivizada.

18 - A fase instrutória da demanda coletivizada funcionará normalmente, comportando a produção de provas sobre os pedidos coletivizados e eventuais pedidos individuais também. Quando da prolação da sentença, deverá ser feita a devida separação nos capítulos pertinentes a cada pedido.

19 - Parece-nos mais adequado a cultura jurídica brasileira, que eventual adoção da técnica em estudo venha acompanhada de lei prevendo sua adoção, o que tem previsão no projeto de lei de novo CPC já aprovado na Câmara dos Deputados, apesar das críticas merecidas por tais disposições, que não preveem a possibilidade de coletivização de oficio, nem a possibilidade dela envolver direitos individuais homogêneos.

20 - A coletivização de demandas individuais encontra um paralelo próximo nos processo por representação e nos litígios em grupo existentes no Reino Unido, já que nessas hipóteses o próprio Tribunal pode coletivizar uma demanda que envolva direito comum ou capaz de se reproduzir em outras demandas individuais homogêneas. 
21- A experiência norte-americana com as classactions, como a mais bem sucedida que se tem noticia, oferece importante auxilio na construção de uma técnica que vise à ampliação do uso do processo coletivo, seja por estabelecer requisitos para a admissão deste, seja no que tange a definição das hipóteses de cabimento, seja, por fim, ao estabelecer os pontos que deverão ser enfrentadas pela decisão que certifica uma ação como coletiva ou, no nosso caso, converte uma ação individual em coletiva.

22 - Existem técnicas já previstas em nosso sistema, tais como a sentença normativa da Justiça do Trabalho, a súmula vinculante, a repercussão geral e os recursos repetitivos, que demonstram a existência de uma preocupação das instituições estatais, com a necessidade de proporcionar maior objetivação à atuação jurisdicional, evitando-se, com isto, a repetição de atividades desnecessárias sobrecasos similares multitudinários, bem como o risco de julgamentos divergentes.

23 - O incidente de resolução de demandas repetitivas, contido no projeto do novo CPC, também confirma essa preocupação, quando permite que uma decisão sobre uma caso repetitivo seja estendida para todos os demais, buscando evitar a insegurança jurídica e prejuízos à isonomia.

24 - A tese do professor Carlos Alberto Salles, também demonstra a pertinência da tese ora proposta, na medida em possui pontos de contato com ela, já que propõe uma ampliação dos efeitos das sentenças que versem sobre direitos sociais constitucionais a todos que possam se beneficiar dela, evitando, com isto, um tratamento desigual a pessoas com o mesmo direito, bem como a multiplicação de demandas visando ao mesmo bem.

25 - No campo dos direitos indivisíveis, a ampliação do uso do processo coletivo poderá, além de reduzir o número de demandas versando sobre o mesmo bem, evitar a ocorrência de conflitos práticos entre decisões divergentes sobre o mesmo direito, o que não é resolvido atualmente pela técnica da coisa julgada secundumeventum litis, permitindo ainda uma extensão in utilibus dos efeitos da decisão aos direitos individuais correspondentes.

26 - No campo dos direitos individuais homogêneos, a potencialização do processo coletivo tornará desnecessário o ajuizamento de demandas individuais multitudinárias, já que uma única será capaz de proporcionar resultado aproveitável por todos os sujeitos que sejam titulares de um direito similar. 
27-Não existem óbices, seja de natureza constitucional, seja de natureza infraconstitucional, à adoção de uma técnica de coletivização judicial de demandas individuais, mesmo porque, eventuais princípios que possam aparentar ser contrários, em verdade foram concebidos num contexto completamente individualista e cuja finalidade não coincidência com a intenção de impedir a coletivização de demandas individuais, se aproximando mais dos objetivos de garantir a imparcialidade do juiz e a participação das partes, bens que não serão atingidos pela coletivização.

28 - A instrumentalidade do processo, tanto no seu aspecto positivo como negativo, confere fundamentos à técnica de coletivização, na primeira vertente, por defender uma ideia de aproveitamento máximo do instrumento na busca pelos seus objetivos, e na segunda vertente, por defender que as nulidades só devam ser reconhecidas quando a informalidade redundar em prejuízo a algum direito ou garantia, o que não ocorrerá nos casos de coletivização, por tudo que vem sendo dito.

29 - A legitimidade individual para demandas coletivas é fundamental para o bom funcionamento de uma técnica de coletivização da demanda individual, pois permite que a parte continue como autora, ao lado do M.P. que já é um legitimado legal, sem que qualquer outro legitimado tenha necessariamente que intervir como parte.

30 - O processo civil pátrio já é recheado de mecanismos voltados a evitar o uso abusivo do processo, que precisam apenas de ser aplicados, sem que se possa confundir legitimidade individual para demandas coletivas com a ideia de abuso processual.

31 - A participação obrigatória do M.P., os poderes instrutórios do juiz e as técnicas de coisa julgada secundumeventum litis e secundumeventumprobationem são suficientes para impedir que a má atuação do indivíduo prejudique a coletividade, pois o M.P. é um dos legitimados legais para todo tipo de ação coletiva e a sistemática da coisa julgada na esfera coletiva não permite prejuízo a direitos individuais, sendo que os indivisíveis serão afetados apenas quando a sentença for de procedência ou, sendo de improcedência, se fundar nas provas dos autos.

32 - O sistema já oferece situações em que o individuo terá legitimidade para representar uma coletividade, como nos casos de ação penal privada subsidiária da publica, de ações pseudoindividuais e de ações populares, que são cabíveis em inúmeras hipóteses 
relativas a direitos indivisíveis, permitindo-nos questionar o que essas hipóteses possuem na sua essência, que justificaria a legitimidade individual apenas para elas.

33 - A instrumentalidade do processo, emambos os aspectos, também subsidia a legitimidade individual, pois se ela não traz risco de prejuízo não há que se falar em nulidade, e se ela proporcionar uma ampliação no uso do processo coletivo e no acesso aos direitos estará em convergência com o aspecto positivo da instrumentalidade.

34 - A legitimidade extraordinária do individuo não caracteriza abuso de poder, mas sim ampliação das suas possibilidades de participação nos rumos da sociedade, podendo ser benéfica à pretendida ampliação do uso da tutela coletiva, na medida em que os atuais legitimados não dão vazão ao volume de litígios massificados existentes hoje, de modo que o rol de legitimados previsto em lei, não deva ser compreendido como taxativo e excludente do indivíduo.

35-Coletivizada demanda pseudoindividual, ela proporcionará uma coisa julgada secundumeventumprobationis, reduzindo, com isto, o risco de conflitos práticos entre sentenças divergentes sobre direitos indivisíveis, que não comportem a utilização da coisa julgada secundumeventum litis.

36 - Outrossim, a coletivização nesse caso proporcionará ainda, que eventual resultado positivo obtido com demanda coletiva, que tenha por objeto direito indivisível, seja estendida e aproveitada em demandas individuais correspondentes aquela.

37 - No campo dos direitos individuais homogêneos, a ampliação da tutela coletiva permitirá uma redução das demandas individuais multitudinárias, que congestionam o Judiciário com processos repetitivos e, portanto, desnecessários, todavia, para que tal efeito seja potencializado, mostra-se importante uma compreensão mais abrangente do termo direito individual homogêneo, para abarcar a todos os direitos que tenham origem comum, seja ela jurídica ou fática, ainda que não haja uma exata predominância de questões comuns, porque ainda nesses casos o processo coletivo trará resultados benéficos, com a centralização e uniformização da decisão sobre a questão comum que estiver na origem do litigio.

38 - Restringir a compreensão do termo direito individual homogêneo não é uma solução eficaz, pois poderá ser burlada pelo uso de demandas coletivas que, versando sobre 
direitos indivisíveis correspondentes a mesma situação fática, estenderão seus efeitos benéficos às respectivas pretensões individuais.

39 - O fato de haver uma desintegração da tutela coletiva sobre direito individual, quando se mostra necessária a liquidação e a execução individuais, não é suficiente para afastar o uso do processo coletivo e mais, existem mecanismos em nosso próprio sistema que permitiriam uma redução na necessidade da liquidação e execução individual.

40 - Um desses mecanismos é o uso da tutela mandamental, para impor que o réu numa ação coletiva cumpra voluntariamente a decisão, sob pena de multa individual, quando puder identificar os beneficiários da decisão e seus respectivos direitos, por manter relação jurídica continuativa com os mesmos, o que será precedido de uma contraditório e poderá ser objeto de modificação a qualquer momento.

41 - Dentro do microssistema da tutela coletiva, enxerga-se a remessa necessária como uma garantia extensível a todo processo coletivo julgado desfavoravelmente a coletividade, o que confere ainda mais segurança a utilização dessa técnica e, portanto, facilita ainda mais a defesa da coletivização judicial de demandas individuais e da legitimidade individual para demandas coletivas.

42 - Os mecanismos de informação do processo coletivo se dividem basicamente em dois, quais sejam: a publicação de edital, para permitir a intervenção de indivíduos ou legitimados como litisconsortes; a intimação no processo individual, sobre a existência de demanda coletiva correspondente, verse ela sobre direito difuso, coletivo stricto sensu ou individual homogêneo, para que a parte possa optar por se aproveitar dos seus efeitos positivos.

43 - É de fundamental importância para um fluxo adequado dos processos coletivos no país, a criação de um cadastro nacional, que permita ao Judiciário operar técnicas de reunião processual, como conexão ou continência, ou ainda de extinção processual, para se evitar a repetição desnecessária de atos e julgamentos, em casos de litispendência e coisa julgada. 


\section{REFERÊNCIAS}

ABDO, Helena Najar; et al. In: COSTA, Susana Henriques da (Coord.). Comentários à Lei de Ação Civil Pública e Lei de Ação Popular.São Paulo: QuartierLatin, 2006.

ABELHA RODRIGUES, Marcelo. Ação civil pública e meio ambiente. Rio de Janeiro: Forense, 2003.

. "A distribuição do ônus da prova no Anteprojeto do Código Brasileiro de Processos Coletivos."In: GRINOVER, Ada Pellegrini; MENDES, Aluisio Gonçalves de Castro; WATANABE, Kazuo. Direito processual coletivo e o anteprojeto de Código Brasileiro de Processos Coletivos. São Paulo: Revista dos Tribnunais, p. 244-254, 2007.

AFONSO DA SILVA, José. Ação popular constitucional: doutrina e processo. 2. ed. rev. ampl. e aum. São Paulo: Malheiros, 2007.

O sistema representativo, democracia semidireta e democracia participativa.

Revista do Advogado, ano XXIII, n. 73, p. 94-109, novembro de 2003.

AFONSO DA SILVA, Virgilio. Direitos fundamentais: conteúdo essencial, restrições e eficácia. $2^{a}$ ed. São Paulo: Malheiros, 2010.

ALEXANDER, Janet Cooper."An introduction to Class Actions Procedure in the United States”.Disponível em:http://law.duke.edu/grouplit/papers/classactionalexander.pdf., p. 125, Consultado em: 19 de setembro de 2013.

ALEXY, Robert. Teoria dos direitos fundamentais.São Paulo: Malheiros, 2008.

ALMEIDA, Gregório Assagra de. Direito processual coletivo brasileiro: um novo ramo do direito processual (princípios, ...). São Paulo: Saraiva, 2003.

ÁLVARES, Samantha Lopes; OLIVEIRA, Guilherme José Braz de. In: COSTA, Suzana Henriques da. (Coord). Comentários à Lei de Ação Civil Pública e Lei de Ação Popular. São Paulo: QuartierLatin, 2006.

AMARAL, Guilherme Rizzo. "Efetividade, segurança, massificação e a proposta de um “incidente de resolução de demandas repetitivas." Revista de Processo,São Paulo: Revista dos Tribunais, ano 36, n. 196, p. 237-276, junho 2011.

ANDREWS, Neil. O moderno processo civil: formas judiciais e alternativas de resolução de conflitos na Inglaterra. Orientação e revisão da tradução Teresa Arruda Alvim Wambier. São Paulo: Revista dos Tribunais, 2009.

ARENHART, Sérgio Cruz. "A tutela de direitos individuais homogêneos e as demandas ressarcitórias em pecúnia.'In: GRINOVER, Ada Pellegrini; MENDES, Aloisio Gonçalves de Castro; WATANABE, Kazuo (Coord.). Direito processual coletivo e o anteprojeto de código brasileiro de processos coletivos. São Paulo: Revista dos Tribunais, 2007.

; MENDES, Aluísio Gonçalves de Castro; OSNA, Gustavo. "Cumprimento de sentenças coletivas: da pulverização à molecularização." Revista de Processo, ano 38, vol. 222, p. 41-64, agosto / 2013. 
ARRUDA ALVIM NETTO, José Manuel. Obrigações de fazer e não fazer - direito material e processo. Revista de Processo, vol. 99, p. 27, jul / 2000.

ASHLEY, Marc D. "The scope and timing of discovery in antitrust class action litigation". The AntritrustPractitioner. Volume 5, December 2006.

BAPTISTA DA SILVA, Ovídio A. Democracia moderna e processo civil. In: DINAMARCO, Candido Rangel; GRINOVER, Ada Pellegrini; WATANABE, Kazuo (Coord.). Participação e Processo.São Paulo: Revista dos Tribunais, p. 98-113, 1988.

BARBOSA MOREIRA, José Carlos. “A ação popular no direito brasileiro como instrumento de tutela jurisdicional dos chamados 'interesses difusos"'. Revista de Processo, ano VII, n. 28, p. 7-21, outubro-dezembro de 1982.

. "A efetividade do processo de conhecimento." Revista de Processo, São Paulo: Revista dos Tribunais, vol. 74, p. 126-137, 1994.

. "A função social do processo civil moderno e o papel do juiz ..." Revista de Processo, São Paulo, n. 37, p. 140-150, janeiro/março 1985.

. "A garantia do contraditório na atividade de instrução". Revista de Processo, São Paulo, n. 35, p. 231-238, julho/setembro 1984. 251, Jan/2000.

"A sentença mandamental da Alemanha ao Brasil." Revista de Processo,v. 97, p.

. "A tutela especifica do credor nas obrigações negativa." In: Temas de

Direito Processual. $2^{\mathrm{a}}$ série, $2^{\mathrm{a}}$ ed. Saraiva: São Paulo, 1988.

. "Breves reflexiones sobre lainciviativa oficial ..." Temas de Direito Processual Civil.3. Série. São Paulo: Saraiva, p. 79-86, 1984.

Litisconsórcio unitário. Rio de Janeiro: Forense, 1972.

. "Notas sobre o problema da 'efetividade' do processo". Revista da AJURIS. Vol. 29, ano X, Porto Alegre-RS, p. 77-94, 1983.

. “O juiz e a prova.”Revista de Processo,São Paulo, n. 35, p. 178-184, julho/setembro 1984.

. “O problema da 'divisão do trabalho' entre juiz e partes: aspectos terminológicos”.Revista de Processo, São Paulo, n. 41, p. 7-14, janeiro/março 1986.

BARROSO, Luis Roberto. Fundamentos teóricos e filosóficos do novo direito constitucional brasileiro. In: (Org.). A nova interpretação constitucional: ponderação, direitos fundamentais e relações privadas. 2. ed. rev. e atual. Rio de Janeiro: Renovar, 2006.

BARZOTTO, Luis Fernando. A democracia na constituição. São Leopoldo: Unisinos. BEDAQUE, José Roberto dos Santos. In: MARCATO, Antonio Carlos (Coord.). Código de Processo Civil interpretado. São Paulo: Atlas, 2004. 
Direito e processo:influencia do direito material sobre o processo. 5. ed. rev. e ampl. São Paulo: Malheiros, 2009.

Efetividade do processo e técnica processual. 2. ed. São Paulo: Malheiros, 2007.

Poderes instrutórios do juiz.3. ed. rev. atual. eampl., São Paulo: Revista dos

Tribunais, 2001.

Tutela cautelar e tutela antecipada:tutelas sumárias e de urgência. (tentativa de sistematização). 3. ed. rev. e ampl., São Paulo: Malheiros, 2003.

BOBBIO, Norberto. Estado, governo, sociedade: para uma teoria geral da politica. Trad. Marco Aurélio Nogueira, 9. ed. Rio de Janeiro: Paz e Terra, 2001.

O futuro da democracia: uma defesa das regras do jogo. Tradução de Marco Aurélio Nogueira, 6. ed. Rio de Janeiro: Paz e Terra, 1997.

BONAVIDES, Paulo. Ciência Política.10. ed. São Paulo: Malheiros, 2002.

BONICIO, Marcelo José Magalhães. "Análise da tendência jurisprudencial de potencialização dos efeitos da regra prevista no art. 543-C do CPC." Artigo ainda não publicado.

; SICA, Heitor Vitor Mendonça. "Ensaio sobre os aspectos materiais e processuais do litisconsórcio unitário."In: MENDES, Aluisio Gonçalves de Castro; WAMBIER, Teresa Arruda Alvim (Coord.). O processo em perspectiva: jornadas brasileiras de direito processual. São Paulo: Revista dos Tribunais, p. 277-304, 2013.

Proporcionalidade e processo: a garantia constitucional da proporcionalidade, a legitimação do processo civil e o controle das decisões judiciais. São Paulo: Atlas, 2006.

BRASIL. Anteprojeto de Código Brasileiro de Processos Coletivos. In: GRINOVER, Ada Pellegrini; MENDES, Aluisio Gonçalves de Castro; WATANABE, Kazuo (Coord.). Direito processual coletivo e o anteprojeto de Código Brasileiro de Processo Coletivos. São Paulo: Revista dos Tribunais, 2007.

. Conselho Nacional de Justiça. Relatório 100 maiores litigantes. Disponível em: <http://www.cnj.jus.br/images/pesquisasjudiciarias/pesquisa_100_maiores_litigantes.pdf>. Acesso em: 30.05..2014.

Disponível em: http://www.cnj.jus.br/noticias/9783-pais-tem-quase-90-milhoesde-processos-em-tramitacao-na-justica. Acesso em: 30.05.2014.

. Disponível em: http://legis.senado.leg.br/mateweb/arquivos/mate-pdf/151972.pdf, p. 170. Acesso em: 27 de junho de 2014.

.Disponívelem:http://siteresources.worldbank.org/BRAZILINPOREXTN/Resource s/38171661185895645304/4044168-1186404259243/29Justica.pdf.

. Superior Tribunal de Justiça. CC 109435 / PR, Conflito de Competência 2009/0240560-8, Min. Napoleão Nunes Maia Filho, S3 - Terceira Seção, data do 
julgamento: 22-09-2010, data da publicação: DJe 15-12-2010. Disponível em: www.stj.jus.br. Acesso em: 22 de julho de 2014.

Superior Tribunal de Justiça. AgRg no REsp, Agravo Regimental no Recurso Especial n ${ }^{\circ}$ 103853/SC, Min. Sidnei Beneti, Terceira Turma, julgado em 27/03/2012 e publicado em 12/04/2012. Disponível em: www.stj.gov.br. Acesso em: 13 de jun. de 2012.

Superior Tribunal de Justiça. AgRg no REsp 264681 / MS, Agravo Regimental no Recurso Especial 2012/0253907-3, Min. Arnaldo Esteves Lima, T1 - Primeira Turma, data do julgamento: 17-10-2013, data da publicação: DJe 30-10-2013, disponível em: www.stj.jus.br, consultado em: 25-12-2013.

Superior Tribunal de Justiça. AgRgno REsp 888328 / RS, Agravo Regimental no

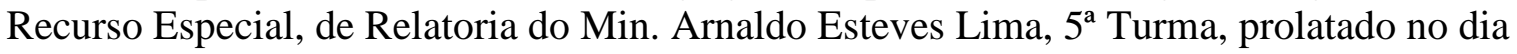
06 e publicado no dia 24/11/2008, Disponível em: www.stj.gov.br. Acesso em: 11 de jun. de 2012.

Superior Tribunal de Justiça. AgRg no REsp, Agravo Regimental no Recurso Especial no 1264045 / RS, Min. Mauro Campbell Marques, Segunda Turma, julgado em 11/10/2012, publicado em 18/10/2011. Disponível em: www.stj.gov.br. Acesso em: 12 de jun. de 2012.

Superior Tribunal de Justiça. AgRg no REsp 1436274 / PI, Agravo Regimental no Recurso Especial2014/0006756-6, Min. Humberto Martins, Órgão Julgador: Segunda Turma, data do julgamento: 01-04-2014, data da publicação: DJe 07/04/2014, disponível em: www.stj.jus.br, acesso em: 15-05-2014.

Superior Tribunal de Justiça. REsp 549587/PE, Recurso Especial 2003/00997128, Rel. Min. Felix Fischer, $5^{\text {a }}$ Turma do Superior Tribunal de Justiça, DJe de 10/05/2004. Disponivel em: www.stj.jus.br. Acesso em: 05 de julho 2013.

Superior Tribunal de Justiça. REsp 797963/GO, Recurso Especial 2005/01896708, Rel. Min. Nancy Andrighi, $3^{\text {a }}$ Turma do Superior Tribunal de Justiça, DJe de 05/03/2008. Disponível em: www.stj.jus.br. Acesso em: 17 de setembro de 2013.

Superior Tribunal de Justiça. REsp 1110549 / RS, Recurso Especial, Rel. Ministro Sidnei Beneti, Segunda Seção, julgado em 28/10/2009, DJe 14/12/2009. Disponível em: www.stj.jus.br. Acesso em: 02 de julho de 2014.

Supremo Tribunal Federal. ADI 173/DF. Relator: Min. Joaquim Barbosa, julgamento: 25/09/2008, órgão julgador: Tribunal Pleno, requerente: Confederação Nacional da Indústria - CNI, requerido: Congresso Nacional, publicação: DJ 20-03-2009. Disponível em: <http://www.stf.jus.br/portal/jurisprudencia>. Acesso em: 03 de abr. 2014.

Supremo Tribunal Federal. AgRg no AI 516.419/PR, Agravo Regimental no Agravo de Instrumento, $2^{\text {a }}$ Turma do Supremo Tribunal Federal, Rel. Min. Gilmar Mendes, DJe de 30/11/2010. Disponível em: www.stj.jus.br. Acesso em: 17 de setembro de 2013.

Supremo Tribunal Federal. Estatísticas do STF: movimento processual. Brasília 2010. Disponívelem: http://www.stf.jus.br/portal/cms/verTexto.asp?servico=estatistica\&pagina=movimentoProc essual. Acesso em 02 de março de 2014. 
BRASIL JÚNIOR, Samuel Meira. Justiça, direito e processo. A argumentação e o direito processual de resultados justos. São Paulo: Atlas, 2007.

BUENO, Cassio Scarpinella. Amicuscuriae no processo civil brasileiro: um terceiro enigmático. São Paulo: Saraiva, 2006.

" "As classactions norte-americanas e as ações coletivas brasileiras: pontos para uma reflexão conjunta." Revista de Processo.n. 82, p. 92-151.

In: MARCATO, Antonio Carlos (Coord.). Código de Processo Civil interpretado. São Paulo: Atlas, 2004.

. Curso sistematizado de direito processual civil: procedimento comum: ordinário e sumário,2: tomo I. 3. ed. rev. e atual. São Paulo: Saraiva, 2010.

. Curso sistematizado de direito processual civil: teoria geral do direito processual civil,1. 2. ed. rev. atual. eampl. São Paulo: Saraiva, 2008.

CALAMANDREI, Piero. Instituciones de derechoprocesal civil.Trad. Santiago SentísMelendo, Buenos Aires: Libreria "El Foro", V. 1.

CAMBI, Eduardo. A prova civil: admissibilidade e relevância. São Paulo: Revista dos Tribunais, 2006.

. Divergência jurisprudencial:inversão do ônus da prova e o ônus de antecipar o pagamento dos honorários periciais. Revista Síntese de Direito Civil e Processual Civil, n. 23, mai-jun 2003.

CAPPELLETTI, Mauro. "Formações sociais e interesses coletivos diante da justiça civil". Revista de Processo, Ano II, N. 5, Jan/Mar, 1977.

. Iniciativa probatória deljuez ... Oralidad y laspruebasenel processo civil.Buenos Aires: Ejea, p. 111-135, 1972.

. Juízes legisladores?Porto Alegre: Sérgio Antônio Fabris, 1999.

. "La protecion de interesses colectivos y de grupo enel processo civil."Revista de laFacultad de Derecho, México, UNAM, t. XXVII, n. 105-106, enero-junio de 1977.

CARNEIRO, Athos Gusmão. "Da 'competência' no projeto de lei de nova ação civil pública”. In: CALMON, Petronio; CIANCI, Mirna; et al (Coord.).Em defesa de um novo sistema de processos coletivos: estudo em homenagem a Ada Pellegrini Grinover. São Paulo: Saraiva, 79-87, 2010.

. "Primeiras observações sobre a lei dos recursos repetitivos no STJ." Revista de Processo, São Paulo: Revista dos Tribunais, ano 33, n. 160, p. 83-86, jun. / 2008.

CARNELUTTI, Francesco. Institucionesdel processo civil. Trad. Santiago Sentis Melendo, Buenos Aires: Libreria "El Foro", V. 1.

CAVALCANTE, Jouberto de Quadros Pessoa; JORGE NETO, Francisco Ferreira. Direito Processual do Trabalho. Tomo II, 2. ed. atual. Rio de Janeiro: Lumenjuris, 2005. 
CHIOVENDA, Giuseppe. "Dell'azione nascente dal contrato preliminare". Saggididiritto processual civile. Roma, 1930, 1/110.

CHUEIRI, Miriam Fecchio; SOUZA, Emerson Cortezia de. "A remessa obrigatória e as ações coletivas em espécie - Sistema processual coletivo de proteção ao interesse público." Revista de Processo, ano 36, vol. 200, p. 159-195, outubro/2011.

CINTRA, Antonio Carlos de Araújo; GRINOVER, Ada Pellegrini; DINAMARCO, Candido Rangel. Teoria Geral do Processo. 12. ed. rev. e atual. São Paulo: Malheiros, 1996.

CIPRIANI, Franco. El autoritarismo procesal (y laspruebasdocumentales). Revista IusetPraxis.Talca, v. 13, n. 2, p. 01-08, 2007, versão on-line disponível em:

www.scielo.cl/scielo.php?pid=S0718-00122007000200003\&script=sci_ar... Consulta realizada em 08/11/2011.

. Nelcentenariodelregolamentodi Klein (Il processo civiletralibertà e autorità). RivistadiDirittoProcessuale.p. 969-1004, n. 4, 1995.

COMOGLIO, Luigi Paolo. Etica e tecnicadel "giusto processo". Torino: G. Giappichelli, 2004.

Le prove civili.Torino: Utet, 1998.

COMPARATO, Fábio Konder. A afirmação histórica dos direito humanos. 3. ed. ver. eampl. São Paulo: Saraiva, 2003.

COSTA, Suzana Henriques da."A representatividade adequada e litisconsórcio: o projeto de lei 5.139/2009."In: CALMON, Petronio; CIANCI, Mirna; et al (Coord.). Em defesa de um novo sistema de processos coletivos: estudos em homenagem a Ada Pellegrini Grinover. São Paulo: Saraiva, 2012.

In: (Coord). Comentários à Lei de Ação Civil Pública e Lei de Ação Popular. São Paulo: QuartierLatin, 2006.

COUTURE, Eduardo J. Fundamentos delderechoprocesal civil.Buenos Aires: Depalma, 1997.

CUNHA, Leonardo Carneiro da. "Anotações sobre o incidente de resolução de demandas repetitivas previsto no projeto do novo Código de Processo Civil." Revista de Processo. São Paulo: Revista dos Tribunais, ano 36, vol. 193, p. 255-281, mar. / 2011.

DALLARI, Dalmo de Abreu. Elementos de teoria geral do estado.30. ed. São Paulo: Saraiva, 2011.

DIDIER JÚNIOR, Fredie. Curso de Direito Processual Civil: teoria geral do processo e processo de conhecimento. 12. ed. rev. ampl. e atual. Salvador: Juspodium, 2011

; ZANETI JÚNIOR., Hermes. Curso de Direito Processual Civil. v. 4, 4. ed, 2009. 
"Multa coercitiva, boa-fé processual e supressio: aplicação do

dutytomitigatetheloss no processo civil." Revista de Processo, ano 34, n. 171, p. 35-48, maio / 2009.

; ZANETI JR., Hermes. "Principio da adequação jurisdicional do processo coletivo - benfazeja proposta contida no projeto da nova lei de ação civil pública."In: CALMON, Petronioet al (Coord.). Em defesa de um novo sistema de processos coletivos: estudos em homenagem a Ada Pelegrini Grinover. São Paulo: Saraiva, 2010.

DINAMARCO, Candido Rangel. A instrumentalidade do processo.São Paulo: Revista dos Tribunais, 1987.

. Capítulos de sentença.3. ed. São Paulo: Malheiros, 2008.

. Fundamentos do processo civil moderno.6. ed. São Paulo: Malheiros, 2010, T. 1. . Instituições de Direito Processual Civil. Vol. III, 4. ed. São Paulo: Malheiros. . Instituições de Direito Processual Civil. Vol. IV, São Paulo: Malheiros, 2004. . Litisconsórcio.6. ed. rev. atual. eampl. São Paulo: Malheiros, 2001. Processo Empresarial. São Paulo: Malheiros, 2010.

DINAMARCO, Pedro da Silva. Ação civil pública.São Paulo: Saraiva, 2001.

DONELAN, Charles. "Prerequisites to a Class Action Under New Rule 23."10 B.C.L. Rev. 527 (1969), p. 534, Disponível em: http: //lawdigitalcommons.bc.edu/bclr/vol10/iss3/6. Consultado em: 24 de setembro de 2013.

ECHANDIA, Hernando Devia. Teoria general de laprueba judicial.5. Ed. Buenos Aires: Vitor S. Zavalia, 1981, tomo 1.

ESTEVES, Carolina Bonadiman. In: COSTA, Suzana Henriques da. (Coord). Comentários à Lei de Ação Civil Pública e Lei de Ação Popular. São Paulo: Quartier Latin, 2006.

EUA.“Brown v. Board of Education.'Disponível em: https://supreme.justia.com/us/347/483/case.html. Consultado em: 26 de setembro de 2013. . Disponível em: www.law.cornell.edu/rules/frcp/rule_23. Consultado em: 10 de outubro de 2013.

."History of Brown V. Board of Education.”Disponível em: http://www.uscourts.gov/educational-resources/get-involved/federal-courtactivities/brown-board-education-re-enactment/history.aspx. Consultado em $19 \mathrm{de}$ setembro de 2013.

FERRAZ, Leslie Shérida. In: COSTA, Suzana Henriques da. (Coord). Comentários à Lei de Ação Civil Pública e Lei de Ação Popular. São Paulo: QuartierLatin, 2006. 
FERRAZ, Sérgio. Assistência litisconsorcial no direito processual civil.São Paulo: Revista dos Tribunais, 1979.

FISS, Owen. Um novo processo civil:estudos norte-americanos sobre Jurisdição, Constituição e sociedade. Coordenação da tradução Carlos Alberto Sales; tradução Daniel Porto Godinho da Silva, Melina de Medeiros Rós, São Paulo: Revista dos Tribunais, 2004.

FLORES, Charles R. "Appealing Class Action Certification Decisions Under Federal Rule Of Civil Procedure 23(F)," Setton Hall Circuit Review: Vol. 4: Iss. 1, Article 2, p. 04. Disponível em: http://erepository.law.shu.edu/circuit_review/vol4/iss1/2. Consultado em: 24 de setembro de 2013.

FREDERICO MARQUES, José. Elementos de direito processual penal.2. ed. atual. Campinas: Millenium, 2000.

FRIEDENTHAL, Jack H.; KANE, Mary Kay; MILLER, Arthur R. Civil procedure.St. Paul: West PublishnigCo., 1985.

GAGNO, Luciano Picoli. Direito fundamental de acesso à justiça e técnicas de otimização da atividade e do juízo probatórios. Dissertação de mestrado orientada pelo Prof. Dr. José Roberto dos Santos Bedaque, aprovada como requisito para a conclusão do curso de mestrado em direito e garantias fundamentais pela Faculdade de Direito de Vitória FDV/ES, no ano de 2010.

- "Direito individual homogêneo: em busca de uma interpretação mais coerente com o direito fundamental de acesso à justiça." p. 252. Disponível em: http://www.conpedi.org.br/manaus/arquivos/anais/brasilia/12_619.pdf. Consultado em: 15 de outubro de 2013.

GALINDO, Bruno. Direitos Fundamentais: analise de sua concretização constitucional. Curitiba: Juruá, 2006.

GIDI, Antonio. Coisa julgada e litispendência em ações coletivas. São Paulo: Saraiva, 1995.

GIGLIO, Wagner D. Direito processual do trabalho / Wagner D. Giglio, Claudia Giglio Veltri Corrêa. 15. ed. ver. e atual. São Paulo: Saraiva, 2005.

GRAY, Joshua B.; SEAGULL, Michelle H. "Class Action Reaction: Amended Rule 23 Enhances Judicial Supervision in Class Litigation."Antitrust, volume 18, n. 2, p. 91-96, Spring 2004, p. 92-93.

GRINOVER, Ada Pellegrini. “Ação civil pública refém do autoritarismo.” Revista de Processo, n. 96, outubro-dezembro/1999.

. "Ações coletivas para a tutela do ambiente e dos consumidores - a lei 7.347, de 24.7.85."Revista de Processo, ano 11, n. 44, p. 113-128, outubro-dezembro de 1986. . "Coisa julgada erga omnes, secundumeventum litis e secundumprobationem." Revista de Processo, v. 126, São Paulo: Revista dos Tribunais, agosto de 2005. 
et al. Código brasileiro de defesa do consumidor: comentado pelos autores do anteprojeto. 8. ed. São Paulo: Forense, 2005.

; NERY JUNIOR, Nelson; WATANABE, Kazuo; et al. Código Brasileiro de Defesa do Consumidor: comentado pelos autores do anteprojeto. $9^{\mathrm{a}}$ ed. Rio de Janeiro: Forense, 2007.

. "Das classaction fordamages à ação de classe brasileira:os requisitos de admissibilidade."Revista Forense, Rio de Janeiro, vol. 352, p. 3-14, out-nov-dez. 2000.

" "Direito Processual Coletivo." In: ; MENDES, Aluisio Gonçalves de Castro; WATANABE, Kazuo (Coord.). Direito processual coletivo e o anteprojeto de código brasileiro de processos coletivos. São Paulo: Revista dos Tribunais, p. 11-15, 2007.

. O processo em evolução. Rio de Janeiro: Forense, 1996.

; MULLENIX, Linda; WATANABE, Kazuo. Os processos coletivos nos países de civil law e common law: uma análise de direito comparado. São Paulo: Revista dos Tribunais, 2008.

$\overline{\text { vol. } 79,}$, p. 65 , jul/1995.

KELSEN, Hans. A democracia.São Paulo: Martins Fontes, 1993.

KLIPPEL, Rodrigo. Aspectos atuais sobre a remessa necessária. Revista da Procuradoria Geral do Estado do Espirito Santo. Vitória: PGE/ES, v. 7, n. 7, p. 53-92, 1\%/2ºm. 2008.

KNIJNIK, Danilo. A prova nos juízos cível, penal e tributário. Rio de Janeiro: Forense, 2007.

LENZA, Pedro. Teoria Geral da Ação Civil Pública.3. ed. rev. atual. eampl. São Paulo: Saraiva, 2008.

LEONEL, Ricardo de Barros. Manual do Processo Coletivo.São Paulo: Revista dos Tribunais, 2002.

LIEBMAN, Enrico Tulio. Eficácia e autoridade da sentença e outros escritos sobre a coisa julgada.3. ed., Rio de Janeiro: Forense, 1984.

. Lezionididirittoprocessualecivile. Milano: Dott. A. Giuffrè - Editore, 1951, v. 1.

LIND, JoEllen. "Procedural Swift': Complex Litigation Reform, State Tort Law, and Democratic Values.’P. 717-778. Disponível em:

http://www.classactionlitigation.com/library/lind37.4.pdf. Consultado em: 15 de outubro de 2013.

LOPES, João Batista. Os poderes do juiz e o aprimoramento ...Revista de Processo, São Paulo, n. 35, p. 24-67, julho/setembro 1984.

LUCON, Paulo Henrique dos Santos. In: MARCATO, Antonio Carlos (Coord.). Código de Processo Civil interpretado. São Paulo: Atlas, 2004. 
MANCUSO, Rodolfo de Camargo. Ação Civil Pública: em defesa do meio ambiente, .... 9. ed. São Paulo: Revista dos Tribunais, 2004.

Ação civil pública: em defesa do meio ambiente, ...12. ed. rev. atual. eampl. São Paulo: Revista dos Tribunais, 2011.

. Ação Popular. 5. rev. atual e ampl. São Paulo: Revista dos Tribunais, 2003.

(Controle jurisdicional dos atos do estado; v. 1 / coordenação Eduardo Arruda Alvim ... [et al.].)

MANDELLI, Alexandre Grandi. TESHEINER, José Maria. "Litispendência em processos coletivos e individuais." Revista Jurídica.Ano 60, n. 420, p. 53-64, outubro de 2012.

MARINONI, Luiz Guilherme; MITIDIERO, Daniel Francisco; SARLET, Ingo Wolfgang. Curso de direito constitucional.São Paulo: Revista dos Tribunais, 2012.

Curso de Processual Civil: Teoria Geral do Processo.São Paulo: Revista dos Tribunais, 2006.

MARTINS, Sérgio Pinto. Direito processual do trabalho: doutrina e prática forense. 28. ed. São Paulo: Atlas, 2008.

MARTINS FILHO, Ives Gandra. Manual esquemático de direito e processo do trabalho. 11. ed. rev., atual. eampl., São Paulo: Saraiva.

MAZZEI, Rodrigo. “A ação popular e o microssistema da tutela coletiva." Revista Forense, Rio de Janeiro: Forense, v. 394, novembro/dezembro, p. 263-282, 2007.

MAZZILLLI, Hugo Nigro. A defesa dos interesses difusos em juízo: meio ambiente, consumidor, patrimônio ... 19. ed. rev. atual. eampl. São Paulo: Saraiva.

. “O ministério público e a jurisdição voluntária.”Disponível em:

http://www.mazzilli.com.br/pages/artigos/mpjurvol.pdf, p. 1-18. Acesso em: 02 de julho de 2014.

MEDINA, José Miguel Garcia; WAMBIER, Luiz Rodrigues; WAMBIER, Teresa Arruda Alvim. "A súmula vinculante vista como meio legitimo para diminuir a sobrecarga de trabalho dos tribunais brasileiros." Revista Jurídica, Porto Alegre: Notadez, ano 57, n. 379, p. 29-52, maio de 2009.

" "Sobre o novo artigo 543-C do CPC: sobrestamento de recursos especiais 'com fundamento em idêntica questão de direito."” Revista de Processo,São Paulo: Revista dos Tribunais, ano 33, n. 159, p. 215-222, maio / 2008.

MENDES, Aluisio Gonçalves de Castro. "A legitimação, representatividade adequada e a certificação nos processos coletivos e as ações coletivas passivas." Revista de Processo, ano 37, vol. 209, p. 243-266, julho / 2012.

Ações coletivas no direito comparado e nacional.2. ed. rev. atual. eampl. São Paulo: Revista dos Tribunais. 
; SILVA, Larissa Clare Pochmann da. "A legitimidade ativa do individuo nas ações coletivas.” Revista de Processo, ano 38, vol. 220, p. 33-49, junho / 2013.

. RODRIGUES, Roberto de Aragão Ribeiro. "Reflexões sobre o incidente de resolução de demandas repetitivas previsto no Projeto de novo Código de Processo Civil." Revista de Processo, São Paulo: Revista dos Tribunais, ano 37, vol. 211, p. 191-208, setembro / 2012.

NASCIMENTO, Amauri Mascaro. Curso de direito processual do trabalho. 21. ed. atual. São Paulo: Saraiva, 2002.

NOYA, Felipe Silva. "O REsp 1.110.549 à luz do devido processo legal: o acesso à justiça individual frente às ações coletivas.” Revista de Processo, v. 197, jul. 2011.

OLIVEIRA, Bruno Silveira de. "Flexibilização do binômio 'processo tradicional' / 'processo coletivo'. Breve análise da presença do individuo em processos coletivos". Revista da Procuradoria Geral do Estado do Espirito Santo,v. 9, n. 9, p. 59-96, $1^{\circ}$ sem. 2010.

OLIVEIRA, Francisco Antonio. Comentários à Consolidação das Leis do Trabalho.3. ed. rev., atual. eampl. São Paulo: Revista dos Tribunais, 2005.

PACE, Nicholas M. "Class Actions in the United States of America: an overview of the process and the empirical literature.Disponível em:

http://globalclassactions.stanford.edu/sites/default/files/documents/USA_National_Report .pdf. p. 1-99. Consultado em 19 de setembro de 2013.

PACELLI DE OLIVEIRA, Eugenio. Curso de processo penal. 16. ed. atual. São Paulo: Atlas, 2012.

PAIVA, Clarissa Teixeira. "A repercussão geral dos recursos extraordinários e a objetivação do controle concreto de constitucionalidade." Revista da AGU.Ano VII - N. 17 - Brasília-DF, p. 47-88, jul./set. 2008.

PERELMAN, Chaim. Lógica jurídica. 2 ed. São Paulo: Martins Fontes, 2004.

PICARDI, Nicola. Il principio delcontraddittorio. RivistadiDirittoProcessuale, Bologna, $\mathrm{n}$. 3, p. 673-681, luglio-settembre, p. 679-700, 1988.

PIMENTA, Natália Martins. Coletivização das demanda individuais: as técnicas processuais de julgamento das demandas individuais à luz do princípio do contraditório. Dissertação apresentada ao Programa de Pós-Graduação Stricto Sensu em Direito Processual Civil da Universidade Federal do Espírito Santo, como requisito parcial para obtenção do titulo de mestre em Direito Processual Civil, sob a orientação do Prof. Dr. Marcelo Abelha Rodrigues.

PINHO, Humberto Dalla Bernardina de. A natureza jurídica do direito individual homogêneo e sua tutela pelo Ministério Público como forma de acesso à justiça. Rio de Janeiro: Forense, 2002.

PIZZORUSSO, Alessandro. Garanziacostituzionaledell'azione. Digesto delle Discipline Privatistiche - SezioneCivile. 4. ed., Torino: UTET, vol. VIII, p. 607-614, 1992. 
PONTES DE MIRANDA, Francisco Cavalcanti. Tratado das Ações.t. VI, São Paulo: Revista dos Tribunais, 1976.

PROTO PISANI, Andrea. In: ALLORIO, Enrico (Coord). Comentariodelcodice de proceduracivile. 1. I, t. II/1.051, Turim, 1973.

RANGEL, Paulo. Direito processual penal.16. ed. rev. atual. eampl. Rio de Janeiro: Lumenjuris, 2009.

REALE, Miguel. O estado democrático de direito e o conflito das ideologias.2. ed. rev. São Paulo: Saraiva, 1999.

REICHELT, Luis Alberto. "A duração do processo, o julgamento do recurso extraordinário dotado de repercussão geral e a modulação dos efeitos da declaração de inconstitucionalidade." Revista de Processo.São Paulo: Revista dos Tribunais, ano 36, vol. 193, p. 131-152, mar. / 2011.

ROUSSEAU, Jean Jacques. Do contrato social: princípios de direito político. Tradução de José Cretella Júnior e Agnes Cretella. São Paulo: Revista dos Tribunais.

SALLES, Carlos Alberto. "Coisa julgada e extensão dos efeitos da sentença em matéria de direitos sociais constitucionais." In: CALMON, Petronio; CIANCI, Mirna; et al (Coord.).Em defesa de um novo sistema de processos coletivos: estudo em homenagem a Ada Pellegrini Grinover. São Paulo: Saraiva, p. 143-158, 2010.

SARLET, Ingo Wolfgang. A eficácia dos direitos fundamentais: uma teoria geral dos direitos fundamentais ... 10. ed. rev. atual. eampl. Porto Alegre: Livraria do Advogado, 2010 .

SAUVEL, T. Histoire du jugement motive.Rev. dr. pub., 1995.

SHIMURA, Sérgio. "A súmula vinculante como mecanismo de tutela coletiva." Revista Jurídica do Ministério Público do Mato Grosso. Cuiabá: Entrelinhas, ano 2, n. 2, jan./jun., p. 117-132, 2007.

SILVA JARDIM, Afrânio. Ação penal pública: princípio da obrigatoriedade. 3. ed. rev. e atual. Rio de Janeiro: Forense, 1998.

TALAMINI, Eduardo. "Partes, terceiros e coisa julgada (os limites subjetivos da coisa julgada)". In: DIDIER JUNIOR. Fredie; WAMBIER, Teresa Arruda Alvim (Coord.). Aspectos polêmicos e atuais sobre os terceiros no processo civil e assuntos afins. São Paulo: Revista dos Tribunais, 2004.

TARUFFO, Michele. "Funzionedella prova: lafunzionedimostrativa." In: Sui confini: scrittisullagiustiziacivile. Bologna: Il Mulino, p. 305-328, 2002.

."Poteriprobatoridelle parti e delgiudice in Europa." Rivistatrimestraledidiritto e proceduracivile, 2006.

. "Senso comune, esperienza e scienzanelragionamentodelgiudice." In:Sui confini: scrittisullagiustiziacivile. Bologna: Il Mulino, p. 121-155, 2002. 
TARZIA, Giuseppe. "Il giusto processo diesecuzione."RivistadiDirittoProcessuale, Bologna, Ano LVII (Seconda Serie), nº 2, p. 329-350, aprile-giugno 2002.

TESHEINER, José Maria. "Do incidente de resolução de demandas repetitivas no anteprojeto de código de processo civil (artigos 895 a 906)." Revista Jurídica,Sapucaia do Sul: Notadez, ano 58, n. 393, p. 27-34, julho de 2010.

THEODORO JÚNIOR, Humberto. “As nulidades no Código de Processo Civil”. Revista de Processo, n. 30, São Paulo: Revista dos Tribunais, abril-junho de 1983.

. Curso de Direito Processual Civil: teoria geral do direito processual civil e processo de conhecimento. Rio de Janeiro: Forense, 2008, v. I.

; et al. "Litigiosidade em massa e repercussão geral no recurso extraordinário." Revista de Processo, São Paulo: Revista dos Tribunais, ano 34, n. 177, p. 9-46, nov./2009.

TUCCI, José Rogério Cruz e. "Anotações sobre a repercussão geral como pressuposto de admissibilidade do recurso extraordinário (Lei 11.418/2006)." Revista de Processo.São Paulo: Revista dos Tribunais, ano 32, n. 145, p. 151-162, mar./ 2007.

. "Código do Consumidor e processo civil: aspectos polêmicos". Revista dos Tribunais.ano 80, vol. 671, p. 32-39, setembro de 1991.

. "Garantia da prestação jurisdicional sem dilações indevidas como corolário do devido processo legal." Revista de Processo, São Paulo: Revista dos Tribunais, n. 66, p. 72-78, abr./jun. 1992.

. “Garantia da prestação jurisdicional sem dilações ...”In: TUCCI, José Rogério Cruz e; TUCCI, Rogério Lauria. Devido processo legal e tutela jurisdicional.São Paulo: Revista dos Tribunais, 1993.

Limites subjetivos da eficácia da sentença e da coisa julgada. São Paulo: Revista dos Tribunais, 2006.

VASCONCELOS, Rita de Cássia Corrêa de; WAMBIER, Luiz Rodrigues. "Sobre a repercussão geral e os recursos especiais repetitivos, e seus reflexos nos processos coletivos." Revista dos Tribunais. São Paulo: Revista dos Tribunais, ano 98, volume 882, p. 25-44, abril 2009.

VENTURI, Elton. A competência jurisdicional na tutela coletiva. In: GRINOVER, Ada Pellegrini; MENDES, Aluisio Gonçalves de Castro; WATANABE, Kazuo (Coord.). Direito processual coletivo e o anteprojeto de Código Brasileiro de Processos Coletivos. São Paulo: Revista dos Tribunais, p. 96-113, 2007.

Processo civil coletivo: a tutela jurisdicional dos direitos difusos, ... São Paulo: Malheiros, 2007.

VERISSIMO, Marcos Paulo. In: COSTA, Suzana Henriques da.___ (Coord). Comentários à Lei de Ação Civil Pública e Lei de Ação Popular. São Paulo: QuartierLatin, 2006. 
VIAFORE, Daniele. "As semelhanças e as diferenças entre o procedimento-modelo alemão Musterverfahren e a proposta de um "incidente de resolução de demandas repetitivas" no PL 8.046/2010.Revista de Processo, São Paulo: Revista dos Tribunais, ano 38, vol. 217, p. 257-310, março / 2013.

WAMBIER, Luiz Rodrigues; WAMBIER, Teresa Arruda Alvim. "Anotações sobre a liquidação e a execução das sentenças coletivas.” In: GRNOVER, Ada Pelegrini Grinover; MENDES, Aluisio Gonçalves de Castro; WATANABE, Kazuo (Coord.). Direito processual coletivo e o anteprojeto de Código Brasileiro de Processos Coletivos. São Paulo: Revista dos Tribunais, p. 263-280, 2007.

WATANABE, Kazuo. “Acesso à justiça e sociedade moderna”. In: DINAMARCO, Candido Rangel et al.Participação e processo. São Paulo: Revista dos Tribunais, p. 128$135,1988$.

et al.Código brasileiro de Defesa do Consumidor: comentado pelos autores do anteprojeto. 6. ed. Rio de Janeiro: Forense, 2000.

. "Relação entre demanda coletiva e demandas individuais".In: GRINOVER, Ada Pellegrini; MENDES, Aluísio Gonçalves de Castro; WATANBE, Kazuo (Coord.).Direito processual coletivo e o anteprojeto de código brasileiro de processos coletivos. São Paulo: Revista dos Tribunais, p. 156-160, 2007.

WEIL, Jeffrey G.; KINT, Brian."Rule 23(f) Class Certification Appeals: Boon or Bust?" The Legal Intelligencer. ALM Media Properties, LLC. Disponível em: http://www.law.com/jsp/pa/PubArticleFriendlyPA.jsp?id=1202548299218. p. 01-04. Consultado em: 12 de outubro de 2013.

YARSHELL, Flávio Luiz. Tutela mandamental nas obrigações de pagamento de quantia. Revista da Procuradoria Geral do Estado de São Paulo.n. especial, p. 270-279, jan./dez. 2003.

YOSHIKAWA, Eduardo Henrique de Oliveira. "O incidente de resolução de demandas repetitivas no Novo Código de Processo Civil: comentários aos arts. 930 a 941 do PL 8.046/2010."Revista de Processo.São Paulo: Revista dos Tribunais, ano 37, vol. 206, 243 272 , abril / 2012.

ZAFFARONI, Eugenio Raúl. Tratado de derecho penal: parte general. Buenos Aires: Ediar, 1998, vol. I.

ZAVASCKI, Teori Albino. "Antecipação de tutela e obrigações de fazer e de não fazer." Revista Jurídica, ano XLV, nº 23, p. 20-34, jul. / 1997.

. "Reforma do processo coletivo: indispensabilidade de disciplina diferenciada para direitos individuais homogêneos e para direitos transindividuais." In: GRINOVER, Ada Pelegrini; MENDES, Aluisio Gonçalves de Castro; WATANABE, Kazuo (Coord.).

Direito processual coletivo e o anteprojeto de Código Brasileiro de Processos Coletivos.São Paulo: Revista dos Tribunais, p. 33-39, 2007. 
ANEXOS 


\section{ANEXO I - PL no 8.046/2010 VERSÃO APROVADA EM 05/11/2013 NA COMISSÃO ESPECIAL DA CÂMARA DOS DEPUTADOS}

\section{CAPÍTULO IV \\ DA CONVERSÃO DA AÇÃO INDIVIDUAL EM AÇÃO COLETIVA}

Art. 334. Atendidos os pressupostos da relevância social e da dificuldade de formação do litisconsórcio, o juiz, a requerimento do Ministério Público ou da Defensoria Pública, ouvido o autor, poderá converter em coletiva a ação individual que veicule pedido que:

I - tenha alcance coletivo, em razão da tutela de bem jurídico difuso ou coletivo, assim entendidos aqueles definidos pelo art. 81, parágrafo único, incisos I e II, da Lei $\mathrm{n}^{\circ}$ 8.078, de 11 de setembro de 1990, e cuja ofensa afete, a um só tempo, as esferas jurídicas do indivíduo e da coletividade;

II - tenha por objetivo a solução de conflito de interesse relativo a uma mesma relação jurídica plurilateral, cuja solução, pela sua natureza ou por disposição de lei, deva ser necessariamente uniforme, assegurando-se tratamento isonômico para todos os membros do grupo.

$\S 1^{\circ} \mathrm{O}$ requerimento de conversão poderá ser formulado por outro legitimado a que se referem os arts. $5^{\circ}$ da Lei 7.347, de 24 de julho de 1985, e 82 da Lei $n^{\circ} 8.078$, de 11 de setembro de 1990.

$\S 2^{\circ}$ A conversão não pode implicar a formação de processo coletivo para a tutela de direitos individuais homogêneos.

$\S 3^{\circ}$ Não se admite a conversão, ainda, se:

I - já iniciada, no processo individual, a audiência de instrução e julgamento; ou

II - houver processo coletivo pendente com o mesmo objeto; ou

III - o juízo não tiver competência para o processo coletivo que seria formado.

$\S 4^{\circ}$ Determinada a conversão, o juiz intimará o autor do requerimento para que, no prazo fixado, adite ou emende a petição inicial, para adaptá-la à tutela coletiva.

$\S 5^{\circ}$ Havendo aditamento ou emenda da petição inicial, o juiz determinará a intimação do réu para, querendo, manifestar-se no prazo de quinze dias.

$\S 6^{\circ} \mathrm{O}$ autor originário da ação individual atuará na condição de litisconsorte unitário do legitimado para condução do processo coletivo.

$\S 7^{\circ} \mathrm{O}$ autor originário não é responsável por qualquer despesa processual decorrente da conversão do processo individual em coletivo.

$\S 8^{\circ}$ Após a conversão, observar-se-ão as regras do processo coletivo.

$\S 9^{\circ}$ A conversão poderá ocorrer mesmo que o autor tenha cumulado pedido de natureza estritamente individual, hipótese em que o processamento desse pedido dar-se-á em autos apartados.

$\S 10$. O Ministério Público deverá ser ouvido sobre o requerimento previsto no caput, salvo quando ele próprio o houver formulado. 


\section{ANEXO II - PROPOSTA DE TÉCNICA DE COLETIVIZAÇÃO JUDICIAL DE DEMANDAS INDIVIDUAIS COMO RESULTADO DESTA TESE \\ VERSÃO ELABORADA COM BASE NO PL Nº 8.046/2010}

\section{CAPÍTULO IV \\ DA CONVERSÃO DA AÇÃO INDIVIDUAL EM AÇÃO COLETIVA}

Art. 334. Observadas as regras de competência do processo coletivo e a dificuldade de formação de litisconsórcio pela numerosidade do grupo, o juiz, de ofício ou a requerimento do autor, do Ministério Público ou da Defensoria Pública, ouvidasas partes, poderá converter em coletiva a ação individual que veicule pedido que tenha alcance coletivo, em razão da tutela de bem jurídico difuso, coletivo ou individual homogêneo, assim entendidos aqueles definidos pelo art. 81, parágrafo único, incisos I, II e III, da Lei $\mathrm{n}^{\mathrm{o}}$ 8.078, de 11 de setembro de 1990;

$\S 1^{\circ} \mathrm{O}$ requerimento de conversão poderá ser formulado por outro legitimado a que se referem os arts. $5^{\circ}$ da Lei 7.347, de 24 de julho de 1985, e 82 da Lei $n^{\circ} 8.078$, de 11 de setembro de 1990.

$\S 2^{\circ} \mathrm{Na}$ decisão sobre a coletivização da ação individual, deverá o juiz explicitamente manifestar-se sobre:

I - a natureza do direito em litigio, ou seja, se difuso, coletivo ou individual homogêneo;

II - as razões que o levaram a concluir pela numerosidade do grupo de afetados, a ponto de justificar a coletivização;

III - qual grupo será afetado pela futura sentença coletiva, especificando a circunstância fática que os une, em se tratando de direito difuso, a relação jurídica base, em se tratando de direito coletivo, ou a origem comum, seja ela fática ou jurídica, em se tratando de direitos individuais homogêneos;

IV - se todos os pedidos existentes na inicial serão coletivizados ou se algum permanecerá individual;

$\mathrm{V}$ - os fundamentos dos pedidos que forem objetos de coletivização.

$\S 3^{\circ}$ Não se admite a conversão, se:

I - ela puder causar atraso relevante ao julgamento da demanda, pela necessidade de se praticar muitos atos que seriam desnecessários no modelo individual, ou pela necessidade de se repetir algo que já tenha sido feito;

II - houver processo coletivo pendente, ou já julgado, com o mesmo objeto;

III - se o autor individual não tiver legitimidade ordinária em relação a sua pretensão individual, não pertencendo ao grupo que será afetado;

IV - se o número de componentes do grupo afetado não for extenso o suficiente para justificar a coletivização; ou

V - o juízo não tiver competência para o processo coletivo que seria formado. 
$\S 4^{\circ}$ Determinada a conversão, o juiz intimará as partes, para que tenham ciência de que o processo se desenvolverá sob as normas do processo coletivo, e que a decisão a ser proferida terá eficácia erga omnes ou ultra partes.

$\S 5^{\circ} \mathrm{O}$ autor originário da ação individual permanecerá na demanda, devendo haver a intervenção obrigatória do Ministério Público, senão como litisconsorte ativo, como fiscal da lei, podendo haver, ainda, a intervenção de outroslitisconsortes ativos que, cientificados da demanda pela publicação de editais,queiram participar do processo.

$\S 6^{\circ} \mathrm{O}$ autor originário não é responsável por qualquer despesa processual decorrente da conversão do processo individual em coletivo.

$\S 7^{\circ}$ Após a conversão, observar-se-ão as regras do processo coletivo. 